\title{
지역문화 성과협약형 포괄보조 방식 도입방안 연구
}

A Study on the Implementation Method of Performance Agreement-Type

Block Grant System of Local Culture 



\section{지역문화 성과협약형 포괄보조 방식 도입방안 연구}

A Study on the Implementation Method of Performance Agreement-Type Block Grant System of Local Culture

정보람·이재원 

연구책임

정보람 한국문화관광연구원 부연구위원

공동연구

이재원 부경대학교 행정학과 교수 

지역문화 성과협약형 포괄보조 방식 도입방안 연구

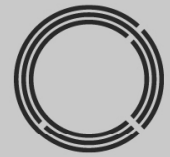

연구개요 



\section{1. 서론}

\section{가. 연구배경 및 목적}

- 지역문화정책, 지자체 이니셔티브 필요 영역

- 분권의 관점에서 볼 때 지역의 문화진흥은 원칙적으로 지역 여건의 실시간 파악 이 가능하고, 지역 내 가용자원을 직접적이고 효율적으로 동원할 수 있는 지방 자치단체가 이니셔티브를 가지고 추진되어야 함

- 그러나 중앙정부와 지방자치단체 간 재정관계는 개별 국고보조방식 고착화로, 지역주도의 계획보다는 중앙에서 설계한 사업을 지방자치단체에서 단순히 실행 /전달하거나 지방자치단체의 부족한 재정 보충에 집중하는 경향

- 국고보조금 비율이 높은 부처, 중앙정부와 지자체 간 재정관계 적극 개편 - 문화체육관광부는 국고보조금 비율이 4번째로 높은 부처, 국고보조금 비율이 높은 부처는 중앙정부 의존형, 종속형 특징이 강화될 수 밖에 없기 때문에 지방 자치단체의 재정자율과 책임을 강화할 수 있는 방안을 적극 도입

- 문화분야처럼 국고보조금이 많은 복지, 농림 분야는 국고보조금의 포괄화, 지방자 치단체 계획에 대한 협약관계 등 중앙정부와 지자체 간 재정관계를 새롭게 개편 추세

- 중앙정부와 지자체 간 기능공유 체제 전환, 성과협약형 포괄보조 방식 검토

- 지역 문화정책에서 중앙정부가 기획하고 지방자치단체가 집행하는 하향식 재정 배분의 한계를 개선하고, 지방자치단체 문화정책을 중앙정부와 지방자치단체가 협력하는 기능공유 체제로 전환

- 정부 간 협약은 행정주체 간의 권한과 역할, 이익, 책임 등을 분명히하고 협력사 항을 사전에 구체화한다는 점에서 분권화에 중요한 수단이며, 단순히 예산지원 방식의 변화를 넘어 정부 간 행정관리 및 평가기법 등 성과관리 체계의 개발을 필요로 함

- 국고보조금의 포괄보조 방식에서 성과관리를 강화하는 측면의 의미로 '성과협 약형 포괄보조 방식' 도입방안을 검토함 


\section{나. 연구범위 및 방법}

- 시공간적 범위: 2021 년 기준, 포괄보조형 시례 및 정부예산 분석

- 포괄보조사업 분석 사례의 시간적 범위는 2021년이고, 공간적 범위는 국내를 중심으로 하되 우리나라의 정부 간 재정관계가 미국 제도의 영향을 많이 받았기 때문에 개념적 이해를 돕기위해 미국의 예시를 포함하여 분석

- 예산에 대한 분석은 정부예산 기능별 분류 16 개분야 69 개 분류 중 '문화 및 관 광 분야 하부의 '문화예술' 부문을 분석하였고, 정부부처 기준으로는 문화체육 관광부 '문화예술정책실' 및 '지역문화정책관' 예산을 분석

- 대상적 범위: 농식품부, 복지부, 문체부의 포괄보조형 사업 사례

- 국고보조사업에서 협약방식, 포괄보조사업의 성과관리 사례 등 관련된 선행사 례 대상은 농림축산식품부 농촌협약, 보건복지부 통합건강증진사업, 지역자율 형 사회서비스투자사업, 문화체육관광부 문화도시조성사업으로 함

- 내용적 범위

- 지역문화 성과협약형 포괄보조 방식 필요성 검토

- 포괄보조사업 성과관리 시례 분석

- 지역문화 성과협약형 포괄보조 기본원칙 및 적용대상 도출

- 지역문화 성과협약형 포괄보조 방식 도입방안 제시

- 연구방법

- 문헌분석(정부 간 협약 또는 계약, 국고보조금 포괄보조 관련 선행연구, 문화체 육관광부 및 지방자치단체 예산서, 사업설명자료 등), 전문가 자문 및 관계자 인터뷰, 공무원 인식조사(설문조사) 등 다양한 연구방법을 활용

- 지방자치단체 설문조사는 전국 243 개 지방자치단체의 문화정책 관련 부서를 대 상으로 성과협약형 포괄보조 관련 사업기획 및 정책과정, 정부 간 관계에 대한 인식과 현황을 조사함 


\section{2. 지역문화 성과협약형 포괄보조 필요성}

\section{가. 성과협약형 포괄보조의 방식의 쟁점}

- 포괄보조, 폭넓게 정의된 기능별 목적에 따라 지원되는 국고보조금 형태

- 국고보조금은 재량권을 기준으로 개별보조금과 포괄보조금으로 구분, 포괄보조 금은 특정 서비스 또는 계층에 대해 설계된 사업에 재정이 지원되는 개별보조금 과 달리 넓게 정의된 기능별 목적에 따라 지원되는 재정지원 형태

- 포괄보조는 현실 정책에서 운용하는 실용적인 용어로 제도의 조건과 형태가 다 양하게 설계될 수 있음

- 포괄보조 방식의 순기능: 지역 실정에 맞는 계획, 재정효율화

- 지방정부는 지역 실정에 맞는 계획을 수립하고 중장기적인 시각에서 사업추진 이 가능하며 예산사용 유연성을 높일 수 있음

- 협약을 체결하는 과정에서 정책성과와 목표에 대해 점검하게 되고 사업수행은 정책효과 관점에서 추진하게 되어, 협약을 통한 관계는 포괄적인 재정지원에 대 한 책임을 명확히하고 정책을 지역 주도로 개편, 재정효율화

- 포괄보조 방식의 한계: 형식적인 재정, 중앙의 개입과 지자체의 순응 여전

- 지방자치단체의 지출재량을 보장해도 포괄 '보조'이기 때문에 중앙정부의 개입 지속, 예산의 용도와 사업 범위에 대한 제약조건 부과

- 보조사업에 잠재된 정보격차와 도덕적 해이, 지방자치단체 입장에서 포괄보조 금은 중앙정부 세입이기 때문에 지역사회 통제로부터 자유로움

- 포괄보조 사업의 지향점 및 전략목표 불명확성, 중앙정부와 지방자치단체 간 성 과관리 체계 연계가 현실적으로 쉽지 않음

〈표 1〉 포괄보조방식의 순기능과 한계

\begin{tabular}{c|c}
\hline 포괄보조방식 순기능 & 포괄보조방식 한계 \\
\hline & - 지자체의 지출재량을 보장해도 포괄 '보조'이기 때문 \\
- 지역 실정에 맞는 계획을 수립하고 중장기적인 시각 & 에 중앙정부의 개입이 계속 강화되는 경향 \\
에서 사업추진이 가능, 예산사용 유연성 확보 & - 보조사업에 잠재된 정보격차와 도덕적 해이에 따른 \\
- 다년간 예산을 보장하기 때문에 사업의 안정성과 실 & 비효율과 무책임 지속 \\
질적인 성과창출을 위한 노력을 기대 & - 중앙정부와 지자체의 성과관리체계 연계가 현실적으 \\
& 로 어렵고, 중앙정부 계획에 형식적으로 순응 \\
\hline
\end{tabular}




\section{나. 지역문화정책에서 성과협약형 포괄보조 필요성}

- 지역문화진흥 정책의 변화: 지역문화 및 생활문화 강조, 포괄화·상향식 접근

- 2014년 「지역문화진흥법」 제정 이후 지역문화 및 생활문화에 대한 관심, 문화 격차 해소와 지역의 문화역량 강화를 중심으로 지역문화정책이 강조

- 문화체육관광부의 생활문화사업 통합지원, 문화도시조성사업, 계획공모형 지역 관광개발사업, 관광거점도시 등 재정의 포괄화와 계획의 상향식 접근방식 확산

- 소액다건형, 국고보조사업의 비효율성

- 국고보조금은 문화체육관광부, 농림축산식품부, 보건복지부, 환경부, 여성가족 부 등 5개 부처에 편중(전체 국고보조금의 78\%)

- 문화체육관광부는 건당 지방자치단체 국고보조금이 가장 작은 부처(1건당 58억 원), 건당 국고보조금이 2.1 억원으로 가장 작고, 이 중 30 개가 보조율 $50 \%$ 대로 낮은 보조율

- 지역문화정책 기반 성장, 종합적 시각의 계획수립 경험 축척

- 지방자치단체의 문화분권 역량은 지방자치단체장을 포함한 담당 공무원의 지역 문화에 대한 이해와 의지, 문화사업 담당인력의 기획능력 및 전문성, 정부 간/ 민관 간/민간 간 협력과 조정 능력

- 전국 243 개 지방자치단체 중 92 개 문화재단 설립, 지역문화전문인력양성으로 인력기반 확보, 생활문화센터, 작은미술관·도서관· 영화관 등 생활문화기반시설

- 지역문화시행계획 수립, 문화특화지역조성, 지역거점문화도시 조성, 문화적 도 시재생 등의 지역기반 등 지역중심 종합적인 계획수립 경험 축척

\section{3. 포괄보조 방식 사례}

\section{가. 분석대상}

- 농촌협약, 지역자율형사회서비스투자, 지역사회통합건강증진, 문화도시

- 지방자치단체에서 계획을 수립하고 중앙정부가 계획에 대한 포괄적 형태의 예 산을 보조하는 성과협약형 포괄보조방식의 사례 
- 농림축산식품부의 농촌협약, 보건복지부의 지역자율형 사회서비스투자사업과 지역사회 통합건강증진사업, 문화체육관광부의 문화도시조성사업에 대한 보조 금 지원방식과 성과관리체계를 중점 검토

\section{나. 포괄보조방식 시사점}

- 유관계획 간 연계, 조직체계 등 전제조건, 지자체 사업구상 자율성 제약 유의

- 계획단계에서 상당히 체계적이고 구체적인 계획서가 요구되고, 대상계획에 기 존 계획과의 연계, 거버넌스 구축 등의 선결조건을 제시

- 계획수립의 전제조건과 예산용도의 제약조건이 너무 상세하게 설계되어 있어 사업 선택권에 제약, 기존의 개별보조사업과 다를 바 없다는 의견

- 중앙-지자체 간 공동의 성과목표, 결과지향적 설정 중요

- 사업계획 수립단계에서 지방자치단체 정책의 장·단기 목표를 구체화하하고, 중 앙정부 정책목표와 지방자치단체의 사업목표를 일치시키고자 노력

- 중앙정부와 지방자치단체가 공동의 목표달성을 위해 노력하는 동시에 지역사회 의 현황, 주민요구도 등을 반영한 계획과 목표지표 설정 요구

- 계획수립부터 관리·운영까지 단계별 컨설팅을 지원, 시도 평가역량 관리

- 지방자치단체의 사업 계획 및 운영 역량을 개발하고 중앙정부와 지방자치단체 의 성과목표를 일치시키기 위해 계획수립 단계부터 운영까지 컨설팅 적극 지원 - 중기기간의 포괄예산을 승인하기까지 예비사업 기간을 두어 상당한 기간을 두 고 지방자치단체로부터 사업대상, 자금의 사용, 관리계획 등을 수정·보완

- 중앙정부의 조직 및 업무방식 일원화 중요

- 중앙정부의 총괄부서 관장과 지방자치단체의 전담조직을 중시, 중앙정부의 업 무를 개편하고 지방자치단체 내 전담조직 설치를 계획의 전제조건으로 두는 등 의 조치

- 그러나 중앙정부 조직의 업무운영방식이 실질적으로 변화하지 않으면 기존의 개별사업 운영 지침에 의해 개별사업과 같은 방식으로 진행되는 한계 


\section{4. 지역문화 성과협약형 포괄보조 가능성 진단}

\section{가. 지역문화 정책 추진현황 검토}

- 중앙정부의 지역문화정책의 목적지향성 확보 필요

- 중앙정부의 지역문화정책의 비전은 분권과 균형발전, 생활기반 문화향유, 지역 문화정책 목표는 지역 간 격차해소, 지역별 특색있는 고유문화의 발전, 지역 주 민 삶의 질 향상

- 비전과 프로그램의 전체 목표 수준과 내용을 고려할 때, 총괄적인 성과지표와 목표 연계 부족, 사업참여자 만족도 등 개별사업에 대한 단순산출 성격

〈표 2〉 중앙정부의 지역문화정책 비전 및 목표

\begin{tabular}{|c|c|c|c|c|}
\hline 구분 & $\begin{array}{l}\text { 문화비전2030 } \\
\text { (2019.2 발표) }\end{array}$ & $\begin{array}{c}\text { 문체부 업무계획 } \\
\text { (2021년) }\end{array}$ & $\begin{array}{l}\text { 문체부 성과관리계획 } \\
\text { (2021년) }\end{array}$ & $\begin{array}{l}\text { 지역문화진흥기본계획 } \\
\text { (2020 2024) }\end{array}$ \\
\hline 계획의 구성 & $\begin{array}{l}\text { 9대의제 47개 대표 } \\
\text { 과제 }\end{array}$ & 4대 전략 15대 과제 & $\begin{array}{c}\text { 6대목표 22대 } \\
\text { 프로그램(성과목표) }\end{array}$ & 4대 전략 15 대 과제 \\
\hline $\begin{array}{c}\text { 지역문화 } \\
\text { 관련 전략 } \\
\text { 및 과제 }\end{array}$ & \begin{tabular}{|l}
-의제6: 지역 문화분 \\
권 실현 \\
-대표과제6-1:지역 \\
문화자치를 위한 기 \\
반 조성. \\
-대표과제6-2: 지역 \\
문화의 고유성 유 \\
지·발전 \\
-대표과제6-3: 지역문 \\
화 거점기관 운영 혁신 \\
과 지원체계 마련 \\
-대표과제6-4: 문화 \\
협치를 위한 협력체 \\
계 구축
\end{tabular} & $\begin{array}{l}\text {-전략2: 문화향유 확대 } \\
\text {-과제2-8:지역문화 진 } \\
\text { 흥 및 균형발전 }\end{array}$ & $\begin{array}{l}\text {-전략1: 삶의 질을 높 } \\
\text { 이는 국민문화 환경 } \\
\text { 조성 } \\
\text {-프로그램1-2: 지역문 } \\
\text { 화 균형발전 및 생활 } \\
\text { 속 문화향유 기회 확 } \\
\text { 대(생활 속 문화기반 } \\
\text { 조성) } \\
\text {-관리과제1-2-1: 지 } \\
\text { 역문화 활성화 }\end{array}$ & $\begin{array}{l}\text { (비전: 포용과 혁신의 지역 } \\
\text { 문화) } \\
\text {-전략1: 시민의 참여로 문 } \\
\text { 화자치 생태계 구축 } \\
\text {-전략2: 포용과 소통으로 } \\
\text { 생활기반 문화환경 조성 } \\
\text {-전략3: 지역의 개성있는 } \\
\text { 문화 발굴·활용 } \\
\text {-전략4: 문화적 가치로 지 } \\
\text { 역의 혁신과 발전 }\end{array}$ \\
\hline $\begin{array}{c}\text { 지역문화 } \\
\text { 관련 성과 } \\
\text { 지표 }\end{array}$ & - & $\begin{array}{l}\text {-지역규모별 문화향유 } \\
\text { 격차 감소 } \\
\text {-박물관·도서관 등 문 } \\
\text { 화기반시설 증가 }\end{array}$ & $\begin{array}{l}\text {-지역문화전문인력 양성 } \\
\text { 사업 참여자 만족도 } \\
\text {-생활문화동호회 지원사 } \\
\text { 업 참여 동호회 수 }\end{array}$ & $\begin{array}{l}\text {-지자체 문화예술 재정 비 } \\
\text { 중 증대 } \\
\text {-지역규모별 문화향유 격 } \\
\text { 차 감소 }\end{array}$ \\
\hline
\end{tabular}

- 지역문화진흥 정책, 문체부 내 여러 부서에서 수행, 단일부서 관리 필요

- 지역문화향유 격차 감소, 지방자치단체 문화재정 증대와 같은 지표는 상위가치 를 반영하고 결과지표의 성격, 다만 지역문화정책 사업과 포괄성·연계성 부족 
- 지역문화정책관의 재정사업은 지역밀착형 시설 확충, 문화도시 조성, 일상 속 생활문화 지원(동호회, 어르신 등) 등이고 대부분의 예산을 박물관, 도서관, 생 활문화센터와 같은 문화시설 건립에 사용

- 상위가치인 생활기반 문화향유를 위해서는 생활문화서비스와 관련된 업무가 조 직(지역문화정책관)의 핵심영역으로 설정되어야 하는데 현재는 예술정책관 소 관이 더 많음

- 포괄보조를 통한 문화분권 활성화를 위해서는 문화예술의 특정 영역에 대해 서 비스, 시설, 인력에 대한 통합적 지원체계 형성 필요

〈표 3〉 문화체육관광부 문화예술정책실 하부 부서별 지자체 국고보조사업(2021년)

\begin{tabular}{|c|c|}
\hline 문화정책관 & \multicolumn{1}{c|}{ 예산 } \\
\hline 전통스토리계승및활동 & 10,236 \\
동학농민혁명정신선양 & 1,200 \\
& \\
전통생활문화진흥 & 1,000 \\
국제문화정책지원 & 600 \\
문화정책개발및진흥 & 540 \\
인문정신문화사회적확산지원 & 300 \\
국학진흥정책기반조성 & 200 \\
& \\
\end{tabular}

\begin{tabular}{|c|r|}
\hline 예술정책관 & \multicolumn{1}{|c|}{ 예산 } \\
\hline 문화예술향유지원 & 123,900 \\
문화예술교육활성화 & 28,088 \\
(지역문화예술교육기반구축) & $(13,045)$ \\
문화예술인프라구축 & 7,086 \\
지역문화예술지원 & 6,127 \\
공공디자인및공예문화진흥 & 1,000 \\
예술의관광자원화 & 643 \\
미술진흥기반구축 & 500 \\
& \\
\end{tabular}

\begin{tabular}{|c|c|}
\multicolumn{2}{l}{ (단위: 백만원 } \\
\hline 지역문화정책관 & \multicolumn{1}{c|}{ 예산 } \\
\hline 문화시설확충 & 261,422 \\
문화도시조성 & 18,000 \\
폐산업시설등유휴공간문 & 10,840 \\
화재생사업 & \\
국민문화향유권확대 & 18,844 \\
박물관·미술관진흥지원 & 16,700 \\
도서관정책개발및서비스환 & 5,310 \\
경개선U-도서관서비스지원 & \\
국민문화활동지원 & 3,600 \\
지역문화기반시설구축 & 400 \\
지역문화진흥 & 370 \\
\hline
\end{tabular}

\section{나. 지역문화 성과협약형 포괄보조 대상 검토}

- 정책 및 재정관리 특성, 지역성, 지표 산출 용이성, 재원배분 객관성 등 기준 - 지역문화 성과협약형 포괄보조 대상사업 선정을 위해, (1)사업의 정책 및 재정관 리 특성, (2)사업시행효과의 지역성, (3)성과지표 산출이 용이성, (4)재원배분의 객관성 등을 기준으로 적격성 검토

- 2021년 문화체육관광부 문화예술정책실 소관 48개 세부사업 184 개 내역사업 분석, 표준화된 서비스 및 품질관리, 국제교류 및 수출지원, 기초연구 및 정보화 사업, 대규모 예산사업 제외 
〈표 4〉포괄보조 대상사업 적합성

\begin{tabular}{|c|c|}
\hline 기준 & 내용 \\
\hline $\begin{array}{l}\text { 사업의 정책 및 } \\
\text { 재정관리 특성 }\end{array}$ & $\begin{array}{l}\text { - 소관부처 내 부서간 저항을 조정하기가 쉬운 영세 보조금 사업 } \\
\text { - 사업성격이 유사하거나 중복되는 사업으로 통합효과가 높은 사업 } \\
\text { - 성과관리에서 지자체 자체사업과 연계성이 높은 사업 } \\
\text { - 세부사업계획과 집행관리에서 지자체 재량 확대를 통해 분권혁신효과 } \\
\quad \text { (재정절감, 성과확대 등)가 기대되는 사업 }\end{array}$ \\
\hline 사업 시행효과의 지역성 & $\begin{array}{l}\text { - 자치단체 고유 업무성격이 강한 사업 } \\
\text { - 자치단체가 실질적인 주체로 활동하는 사업 } \\
\text { - 편익범위나 외부성이 자치단체 지역에 한정되는 국지적인 사업 }\end{array}$ \\
\hline 성과지표 산출의 용이성 & $\begin{array}{l}\text { - 고용, 소득, 생산성, 주민 만족도 등 성과측정이 용이한 사업 } \\
\text { - 국가와 자치단체 간 공통의 성과지표 개발이 용이한 사업 }\end{array}$ \\
\hline $\begin{array}{c}\text { 재원배분의 } \\
\text { 객관적 기준 설정 용이 }\end{array}$ & $\begin{array}{l}\text { - 과거 재정지출 추세를 고려할 때, 지자체별 연차별 재원배분 규모의 예측성과 } \\
\text { 안정성이 높은 사업 } \\
\text { - 미래 재정수요를 전망할 때, 지자체 혹은 지역단위별로 사업의 재정지출 수요 } \\
\text { 가 객관적으로 예측가능하고 안정적인 사업 } \\
\text { - 법적 공식주의 운용 및 이에 필요한 통계자료의 이용가능성 }\end{array}$ \\
\hline
\end{tabular}

- 전통생활문화, 지역문화 활동인력, 지역문화서비스 등 3 가지 포괄보조화

- 전통생활문화는 현재의 '전통생활문화 활성화 지원', '전통놀이문화 조성 및 확산, '세시풍속 맥 잇기', '디지털 생활사 아카이빙 사업'을 하나의 포괄보조 사업화

- 지역의 역사적, 문화적, 생활사적 특성에 따라 중요하게 여기는 가치를 수집, 관리, 활성화, 사업화 측면에서 지방자치단체 자체 계획이 효과적

- 지역문화 활동인력은 현재의 '이야기할머니 인력양성 및 활동지원', ‘인생나눔 교실 운영', '지역문화예술교육 지원', '문화예술교육 전문인력양성', '지역문화 역량 강화', '지역문화 활동가 지원'을 하나의 포괄보조 사업화

- 지방자치단체는 지역의 문화수요 특성과 노동시장 실정에 맞게 인력을 교육하 고 일자리에 연계하여 배치할 수 있음

- 지역 문화서비스 지원은 현재의 '길 위의 인문학', '사회문화예술교육 지원', '생 활문화 활성화', '실버문화페스티벌지원', ‘어르신문화프로그램운영'을 하나의 포괄보조화

- 지방자치단체는 지역의 문화수요 특성과 인구구성, 문화인프라 특성 등 지역 실 정에 맞게 지역 문화향유 프로그램 추진 용이 


\section{다. 지역문화 성과협약형 포괄보조 기반 조사}

- 전국 지자체 문화정책 관련부서 공무원 316명(광역 31명, 기초 285명) 응답 - 조사대상: 전국 243 개 광역 및 기초 지방자치단체의 문화정책 업무담당 공무원 대상 조사, 316명(광역 31명, 기초 285명) 응답

- 조사문항 :포괄보조 방식으로 재정을 지원하고 있는 문화도시사업에 대한 기획 및 정책과정에서의 인식, 정부 간 관계에 있어서 사업재량과 책임, 성과협약형 포괄보조에 대한 인식

- 주요결과 1 : 포괄보조형 사업 지자체, 지역 내 기획역량 및 주민 영향력 확보 - 포괄보조형 사업인 문화도시사업을 추진하는 결정과 실행하기 위해서는 지방자 치단체장의 의지가 $44.9 \%)$ 중요하고, 포괄보조형 사업을 추진하는 지방자치단 체는 지역 내 기획역량과 주민 영향력을 일정수준 확보

- 기획역량에 대해 문화도시를 추진하거나 추진 계획인 지방자치단체는 충분하다 고 평가하고 문화도시와 관계없는 지방자치단체는 불충분 평가(기획역량 충분: 예비도시 $50 \%$, 본도시 $38.9 \%$, 추진예정 $34.7 \%$, 이외 $11.7 \%$ )

- 지역주민 참여/의사결정 영향력에 대해 문화도시를 추진하거나 추진 계획인 지방 자치단체는 충분 평가, 문화도시와 관계없는 지방자치단체는 불충분 평가(지역주 민 영향력 충분: 예비도시 $58.3 \%$, 본도시 $38.9 \%$, 추진예정 $46 \%$, 이외 $20 \%$ )

- 주요결과 2: 포괄보조형 사업 지자체, 지자체 사업계획 및 재정운용 재량 확보 - 문화도시 사업은 ‘사업계획 및 추진 재량 확대'(81.6\%), '전문가 및 주민의 참여 기회 확대'(81.3\%), '지자체 예산편성 및 집행 탄력성 확대'(75.6\%), '지자체 수 요가 반영된 사업 추진 확대'(72.5\%) 등의 긍정 평가

- 포괄보조형 사업이 지자체 사업추진 자율성, 창의성, 유연성 확보에 대부분의 지자체가 기여한다는 의견(기여함 $56.3 \%$, 기여하지 않음 $3.5 \%$ )

- 주요결과 3: 포괄보조형 사업, 중앙정부 계획연계, 지역 수요를 반영한 계획 - 문화도시사업은 중앙정부의 계획과 지방자치단체의 계획이 일치하다는 의견(일 치 $32.9 \%$, 불일치 $10.1 \%)$ 이 높았고 특히 지방자치단체의 계획은 지역수요와 일치하다는 의견(일치 $41.8 \%$, 불일치 $7.9 \%$ )이 높았음

- 지방자치단체에서 집중하고 있는 문화정책 분야는 생활문화, 동호회 등 지역문 
화서비스로 확인되었고, 지방자치단체 차원의 계획·관리가 필요한 분야는 지역 문화 관련 활동인력 양성·배치, 지역문화서비스 지원으로 확인됨

- 주요결과 4: 수행조직의 전문성 중요

- 지역문화사업의 연계·통합 추진을 위해 수행조직의 전문성(45.9\%)을 가장 중요 한 요소로 판단, 지방자치단체의 계획수립(26.9\%), 지방자치단체 장의 사업효 율화 방침(20.6\%) 의견이 있었고 담당공무원의 역량은(5.4\%) 거의 없음

- 포괄보조사업 추진 애로사항으로 수행주체 부재 및 전문성 부족(41.5\%)이 가장 높게 확인되었고, 이외 제한적 재량권(21.8\%), 상위 지방자치단체의 협조 등 재 원조달 문제(21.2\%)에 대한 의견

- 주요결과 5: 중앙정부 관리감독은 적절하나 성과관리 보완 필요

- 문화도시사업의 집행과정과 보조금 지불정산 관련한 중앙정부의 관리감독은 적 절하고(적절 $31.9 \%$, 부적절 9.7\%) 효율적이라는(효율적 30.6\%, 비효율적 $16.7 \%)$ 의견이 높음

- 반면 성과관리는 부적절하다는(적절 $11.1 \%$, 부적절 $19.4 \%$ ) 의견이 높고, 부적 절하다는 이유로는 사업별 특성과 상황이 반영되지 않은 평가기준, 불명확한 평 가기준, 평가대응 행정력 부족 등의 의견 확인

\section{5. 지역문화 성과협약형 포괄보조 방식 도입방안}

\section{가. 중앙부처의 보조사업 체계}

- 국가의 지역문화정책 영역과 목표, 업무영역 재설계

- 포괄보조를 통한 문화분권 활성화를 위해서는 문화예술의 특정 영역에 대해 서 비스, 시설, 인력에 대한 통합적 지원체계 형성 필요

- 현재 지역문화정책관 부서의 소관 재정사업들은 주로 문화시설투자에 대한 것 이므로 시설투자가 프로그램 이용과 유기적으로 결합되고 상호 교환할 수 있도 록 재정의 통합관리 및 재구조화 


\section{문화기반시설 지역문화활동

〈표 5〉 지역문화 성과협약형 포괄보조 사업분류(안)

\begin{tabular}{|c|c|c|}
\hline 포괄보조사업명 & 현행 사업명(내역사업) & 검토이유 \\
\hline 전통생활문화 & $\begin{array}{l}\text { 전통생활문화 활성화 지원 } \\
\text { 전통놀이문화 조성 및 확산 } \\
\text { 세시풍속 맥 잇기 } \\
\text { 디지털 생활사 아카이빙 사업 }\end{array}$ & $\begin{array}{l}\text { 지역을 기반으로 한 생활문화인 전통적 관 } \\
\text { 습과 풍속, 향토문화 자원 등을 수집, 관리, } \\
\text { 상품화 및 디지털화하는 것으로 지역의 고 } \\
\text { 유성이 중시되는 영역 }\end{array}$ \\
\hline 지역문화 활동인력 & $\begin{array}{l}\text { 인생나눔교실 운영 } \\
\text { 이야기할머니 인력양성 및 활동지원 } \\
\text { 지역문화예술교육 지원 } \\
\text { 문화예술교육 전문인력 양성 } \\
\text { 지역문화역량 강화 } \\
\text { 지역문화 활동가 지원 }\end{array}$ & $\begin{array}{l}\text { 지역의 문화전문 인력이라는 명확한 대상에 } \\
\text { 초점을 두고 지역 내 일자리 수요·공급이 이 } \\
\text { 루어지고 있기 때문에 자치단체 차원에서 인 } \\
\text { 적자원 관리가 필요한 영역 }\end{array}$ \\
\hline 지역문화서비스 & $\begin{array}{l}\text { 길위의 인문학 } \\
\text { 사회문화예술교육 지원 } \\
\text { 생활문화 활성화 } \\
\text { 실버문화페스티벌 지원 } \\
\text { 어르신 문화프로그램 운영 }\end{array}$ & $\begin{array}{l}\text { 지역의 인구구성, 생활특성애 따라 주민의 } \\
\text { 문화서비스 선호 및 욕구가 다르기 때문에 } \\
\text { 자치단체 차원에서 지역의 특성을 반영하여 } \\
\text { 세부계획을 세우는 것이 효율적인 영역 }\end{array}$ \\
\hline
\end{tabular}

- 생활권-도시권-광역권 전략적 접근

- (생활권) 지역주민의 생활반경 내 커뮤니티 계획으로 지역 내 인프라-인력-서비 스를 연계하는 계획에 대한 포괄보조를 의미하며, 중앙정부 사업목록을 메뉴화 하고 지방자치단체는 지역 상황에 맞추어 자율적으로 커뮤니티 계획을 수립

- (도시권) 도시 고유의 문화적 정체성과 브랜드를 형성하는 전략에 대한 포괄보 조를 의미한며, 지방자치단체는 도시의 문화적 자원(역사전통, 예술, 문화산업, 사회문화 등) 분석을 기초로하여 도시권 문화브랜드 계획을 수립

- (광역권) 문화적 자원(역사전통, 예술, 문화산업, 사회문화 등), 생활환경의 유사 성 혹은 연결성이 높은 자치단체 간 계획 수립에 대한 포괄보조를 의미하며, 중 앙정부의 ‘(가칭) 지역문화권역' 설정에 따라 지방자치단체 간 공동계획 혹은 개 별 지방자치단체에서 실행계획을 수립 
[그림 1] 생활권-도시권-광역권 포괄보조 전략적 접근 방안

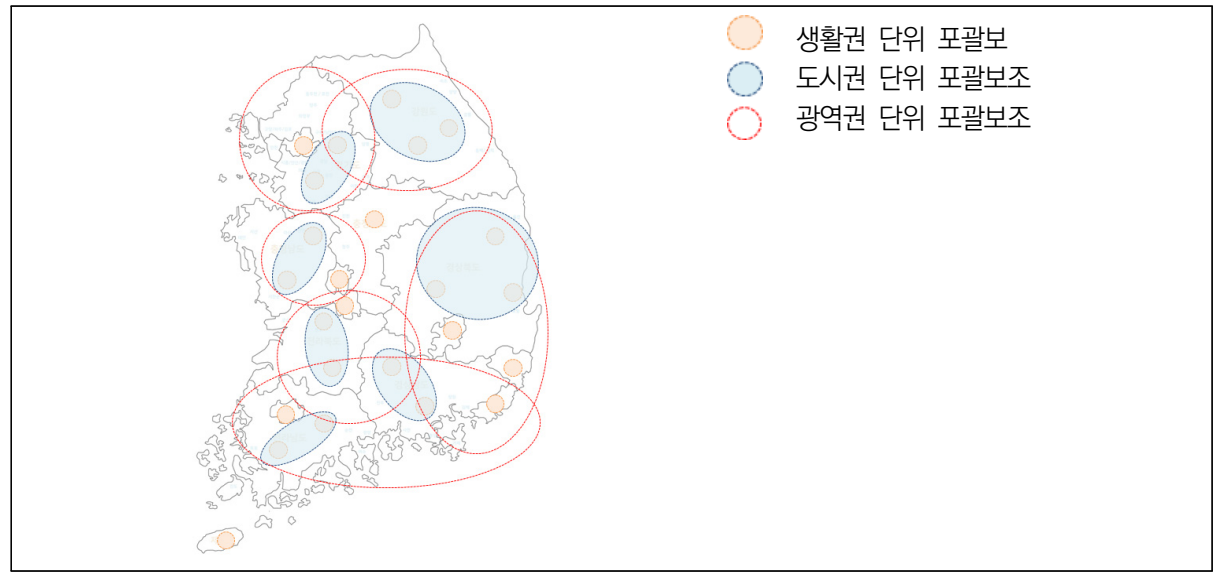

\section{나. 중앙-지자체 간 협조체계 및 재정배분}

- 중앙-지자체 간 신뢰 기반 형성

- 그동안의 포괄보조 방식의 사업의 추진 경험에서 비용-효과성에 순기능이 작동 되지 못한 원인을 중앙정부와 지방자치단체 상호간에 책임성과 신뢰관계 부족 으로 판단되기 때문에 책임성과 신뢰관계 형성을 위해 협약 절차를 포함

- 현실 제도에서 운영됐던 포괄보조프로그램의 다양한 사례와 특성들에 대해 공 유하고 제도시행 전 단계에서 지방정부와 사전 협의와 정례적인 상호 협력체계 의 구축·운영

- 지자체 협약 대상: 기초 vs 광역

- 성과책임을 전담하는 주체에 대한 결정, 광역자치단체의 재정조정 능력이 자치 단체의 특성에 따라 다른 점에 유의해야 함

- 특광역시는 시본청 직접 수행 사업이 많고 자치구에 대한 재정조정기능이 활성 화, 그러나 도는 재정이 전반적으로 취약하고 군의 면적이 넓기 때문에 도에 재 정조정과 사업관리 권한을 부여하면 광역-기초간 재정갈등 우려

- 지역문화 성과협약형 포괄보조 프로그램에 대한 지방자치단체 협약 대상은 특 광역 시는 광역자치단체로 하고, 광역도는 기초자치단체인 군 단위로 설정하는 것이 적절할 것임 
- 재원배분 방식: 지역특성별 맞춤형 프로그램 개발 필요

- 사회 경제 활동이 집중되는 수도권과 지역소멸 우려성이 높은 낙후지역의 지방 자치단체에 대한 포괄보조제도가 동일한 형태로 적용되는 것은 적절하지 않음

- 광역도의 관할구역에 해당되는 지역은 재정자립도가 낮고 문화예술 예산 편성 비중이 낮지만 지역에 인구 백만명 당 문화시설이 많음

- 재정여건이 양호하지 않은 지역에서 인구대비 문화시설 개수가 많으면, 시설건 립 이후 운영 및 활성화에 대한 투자 부족으로 지역격차가 악화될 수 있으므로, 지역유형별 맞춤형 프로그램 개발 필요

- 지방자치단체의 문화수준과 환경변화를 반영할 수 있는 문화권역을 설정하고 이를 기준으로 재원을 객관적으로 배분할 필요

〈표 6〉 지자체별 재정자립도, 문화예술예산, 문화기반시설 수

(단위: 백만원, 개, \%)

\begin{tabular}{c|c|c|c|c|c|c}
\hline \multirow{2}{*}{ 지 역 } & \multicolumn{2}{|c|}{ 재정자립도 } & \multicolumn{2}{c|}{ 지자체 문화예술 부문 예산 } & \multicolumn{2}{c}{ 백만명당 문화시설 수 } \\
\cline { 2 - 7 } & 지수 & 순위 & 예산비중 & 순위 & 개수 & \multicolumn{1}{c}{ 순위 } \\
\hline 서울특별시 & 75.6 & 1 & 1.39 & 12 & 42.14 & 12 \\
\hline 부산광역시 & 46.1 & 6 & 1.94 & 4 & 36.32 & 17 \\
\hline 대구광역시 & 44.6 & 7 & 1.76 & 7 & 36.50 & 16 \\
\hline 인천광역시 & 50.3 & 4 & 1.44 & 11 & 38.89 & 15 \\
\hline 광주광역시 & 40.8 & 8 & 2.84 & 1 & 49.43 & 10 \\
\hline 대전광역시 & 39.9 & 9 & 1.86 & 5 & 42.04 & 13 \\
\hline 울산광역시 & 49.6 & 5 & 2.24 & 2 & 40.07 & 14 \\
\hline 세종특별자치시 & 58.8 & 2 & 2.18 & 3 & 64.60 & 9 \\
\hline 경기도 & 57.3 & 3 & 1.68 & 10 & 42.83 & 11 \\
\hline 강원도 & 24.5 & 15 & 1.73 & 9 & 150.50 & 2 \\
\hline 충청북도 & 28.3 & 13 & 1.30 & 14 & 85.00 & 5 \\
\hline 충청남도 & 32.3 & 12 & 1.29 & 15 & 82.87 & 6 \\
\hline 전라북도 & 23.1 & 16 & 1.80 & 6 & 95.66 & 4 \\
\hline 전라남도 & 22.2 & 17 & 1.15 & 16 & 118.80 & 3 \\
\hline 경상북도 & 24.9 & 14 & 1.35 & 13 & 79.15 & 7 \\
\hline 경상남도 & 33.5 & 10 & 1.08 & 17 & 65.72 & 8 \\
\hline 제주특별자치도 & 32.7 & 11 & 1.76 & 8 & 205.67 & 1 \\
\hline 평 균 & 43.6 & - & 1.55 & - & 58.19 & - \\
\hline ㅈyyyyyyy
\end{tabular}

주: 재정자립도, 지자체 문화예술부문 예산은 2021년, 시설 수는 2020년말 기준

자료: 문화체육관광부(2021), 2020 전국문화기반시설총람

지방재정통합공개시스템(재정365) 
- 포괄보조형 사업에 대한 성과관리 체계화

- 과정관리(Process Control)와 성과관리에(Result Based Management) 대한 구분된 접근과 균형, 현재 문화도시사업은 1 년기간에 대해 과정관리가 아닌 성 과평가를 적용하고 있음

- 1 년기간은 실적에 대한 점검과 모니터링, 컨설팅은 정책수행 과정에서 발생한 문제점, 장애요인, 개선점을 도출하기 위한 과정관리에 목적을 두고, 3 년 혹은 5년 경과시점에 성과목표 달성도를 평가할 필요

- 1 개의 중앙부처가 수 많은 지방자치단체와 성과를 협약하고, 수행 사업의 정보 를 정확하게 수집하고 엄밀하게 점검하는 것은 불가능하므로, 지방자치단체 내 평가기능을 강화할 필요

- 성과평가 결과는 지방자치단체에 실질적 인센티브가 되도록 매칭이 필요없는 특별사업비를 지급하거나 포상금 지급, 재협약 우선권 등을 검토 


\section{목차}

제1장 서론

제1절 연구배경 및 목적 3

1. 연구배경 3

2. 연구목적 4

제2절 연구범위 및 방법 $\quad 5$

1. 연구 범위

2. 연구 방법

제|2장 지역문화 성과협약형 포괄보조 필요성 ……...........................................

제1절 성과협약형 포괄보조의 개요 11

1. 국고보조금의 개념 11

2. 성과협약형 포괄보조의 개념 및 특징 15

3. 성과협약형 포괄보조 방식 사례(미국) 19

4. 성과협약형 포괄보조 방식의 쟁점 29

제2절 지역문화정책에서 성과협약형 포괄보조 필요성 32

1. 지역문화정책과 문화분권 32

2. 정부 간 재정관계 38

3. 지역문화 정책의 여건 변화 45

제3장 포괄보조 방식 사례

제1절 농촌협약(농식품부) $\quad 51$

1. 사례개요 51

2. 운영방식 54

제2절 지역자율형 사회서비스투자사업(복지부) 62

1. 사례개요 62

2. 운영방식 65 
제3절 지역사회 통합건강증진사업(복지부) 77

1. 사례개요 77

2. 운영방식 $\quad 80$

제4절 문화도시 조성사업(문체부) 86

1. 사례개요 86

2. 운영방식 88

제5절 시사점 96

제4장 지역문화 성과협약형 포괄보조 가능성 진단 ……................................... 101

제1절 지역문화 정책 추진현황 검토 103

1. 문화체육관광부 지역문화정책 추진체계 진단 103

2. 지역문화진흥계획 제도와 현황 115

3. 지방자치단체의 문화예산 특징 122

제2절 지역문화 성과협약형 포괄보조 대상 검토 127

1. 성과협약형 포괄보조 방식 적격성 검토 기준 127

2. 성과협약형 포괄보조 방식 적격성 검토 결과 131

제3절 지역문화 성과협약형 포괄보조 기반 조사 137

1. 조사개요 137

2. 분석결과 140

3. 시사점 148

제5장 지역문화 성과협약형 포괄보조 방식 도입방안 ….................................... 151

제1절 중앙부처의 보조사업 체계 153

1. 종합진단 153

2. 추진방안 156

제2절 중앙-지자체 간 협조체계 및 재정배분 163

1. 종합진단 163

2. 도입방안 166 
참고문헌 / 173

ABSTRACT / 177

부록 지자체 설문조사지 양식 / 181 


\section{표 목차}

〈표 2-1〉 보조금관리법에서 국고보조금 유형 규정 12

〈표 2-2〉 지방비 부담의 의무성 정도에 따른 유형화 13

〈표 2-3〉 분권화와 보조금 특징 16

〈표 2-4〉 OECD 국가의 중앙-지방 정부 간 협력방식 유형 18

〈표 2-5〉2020년도 미국 연방정부의 Block Grant 예산 21

〈표 2-6〉 $\mathrm{CDBG}$ 의 예산수립과 실행과정 개요 23

〈표 2-7〉 CDBG의 예산 배분 공식 25

〈표 2-8〉 CDBG-DR 지원 결정통보문 (루이지애나주(Louisiana) 대상, 2017) 28

〈표 2-9〉 CDBG-DR 지원 협약의 주요 내용 (HUD(중앙정부)-루이지애나주, 2017) 28

〈표 2-10〉포괄보조방식의 순기능과 한계 31

〈표 2-11〉정부별 문화분권 특징 33

〈표 2-12〉 생활문화사업 통합지원 내용 36

〈표 2-13〉 국세 대 지방세 비율 38

〈표 2-14〉 지방자치단체 재정자립도 39

〈표 2-15〉지방자치단체 재정자주도 39

〈표 2-16〉 부처별 지방자치단체 국고보조금 현황(2021년) 40

〈표 2-17〉 부처별 보조사업 편성(2021년) 41

〈표 2-18〉 최근 5년간 공모형 국고보조사업의 기능별 분포 42

〈표 2-19〉 공모형 국고보조사업의 국고보조율 분포(2020년) 43

〈표 3-1〉 농촌협약 개요 52

〈표 3-2〉 2022년 농촌협약 대상 지자체 53

〈표 3-3〉 농촌협약 추진단계(2021년 기준) 54

〈표 3-4〉 농촌협약 정책과제 및 사업 예시 56

〈표 3-5〉 평가항목 농촌 공간 전략계획, 기본항목(600점) 57

〈표 3-6〉 평가항목 농촌 공간 전략계획 평가항목 가감점 항목( \pm 30 점) 58

〈표 3-7〉 농촌생활권 활성화 계획 기본항목 (400점) 59

〈표 3-8〉 농촌생활권 활성화 계획 가감점 항목 ( \pm 20 점 $) \quad 61$ 
〈표 3-9〉 지역자율형 사회서비스 투자사업 제공 및 이용자 규모(2019년)

〈표 3-10〉 지역자율형 사회서비스투자사업 예산의 편성 절차

〈표 3-11〉 지역자율형 사회서비스 투자사업 내역사업별 사업내용 66

〈표 3-12〉 지역사회서비스투자사업 기본구조 67

〈표 3-13〉 지역사회서비스투자사업 추진체계 및 기능 68

〈표 3-14〉 산모신생아 건강관리지원사업 기본구조 69

〈표 3-15〉 산모신생아 건강관리지원사업 추진체계 및 기능 70

〈표 3-16〉가사·간병 방문 지원사업 기본구조 71

〈표 3-17〉 가사·간병 방문 지원사업 추진체계 및 기능 72

〈표 3-18〉 지역자율형사회서비스투자사업 시·도 성과평가 추진 경과('13-'20년) 73

〈표 3-19〉 지역자율형사회서비스투자사업 시도평가 추진절차 74

〈표 3-20〉지역자율형사회서비스 투자사업 시도평가 지표(공통평가) 75

〈표 3-21〉 지역자율형사회서비스 투자사업 시도평가 지표(지역특화평가) 76

〈표 3-22〉 지역자율형사회서비스 투자사업 시도평가 영역(지역특화평가) 76

〈표 3-23〉 지역사회 통합건강증진사업 변화 경과 79

〈표 3-24〉2021년 지역사회 통합건강증진사업 핵심성과지표 83

〈표 3-25〉2021년 지역사회 통합건강증진사업 평가단 구성·운영 권장사항 84

〈표 3-26〉 2021년 지역사회 통합건강증진사업 평가지표 총괄표 85

〈표 3-27〉2021년 지역사회 통합건강증진사업 세부평가지표 85

〈표 3-28〉 문화도시 조성사업 개요 86

〈표 3-29〉 문화도시 지정 현황 88

〈표 3-30〉 문화도시 조성계획과 문화도시지정 심의 비교 89

〈표 3-31〉문화 도시 유형과 세부 분야 90

〈표 3-32〉 도시재생뉴딜사업 및 주민참여예산제도 연계방향 90

〈표 3-33〉 문화도시 조성계획 검토, 승인 기준 91

〈표 3-34〉 문화도시 지정심의 기준 92

〈표 3-35〉 문화도시 성과평가 연차별 가중치 조정 계획 93

〈표 3-36〉 문화도시 성과평가 지표 94

〈표 4-1〉2021년 문화체육관광부 업무계획 상 관리지표 104

〈표 4-2〉 문체부 성과계획서 전략목표1의 프로그램 체계 105

〈표 4-3〉 문체부 지역문화진흥 관련 성과계획서의 성과지표와 성과목표 106

〈표 4-4〉 문체부 지역문화정책 성과지표(성과관리 시행계획) 107

〈표 4-5〉 문화체육관광부 부문별 국고보조금 현황(2021년) 108 
〈표 4-6〉 문화체육관광부 소관 사업 수(2021년)

〈표 4-7〉 문체부 문화예술정책실 소관 지자체 국고보조사업(2021) 109

〈표 4-8〉 문체부 지역문화정책관 소관 예산사업

〈표 4-9〉 지역문화 진흥 관련 국고보조사업의 규모 추이

〈표 4-10〉 문화시설확충 사업내용(균특회계 지역자율)

〈표 4-11〉 전국 문화기반시설 연도별 현황(개)

〈표 4-12〉 전국 재정여력 및 문화기반시설 현황

〈표 4-13〉시도 지역문화진흥 시행계획 구성

〈표 4-14〉시도 지역문화진흥 시행계획 전략과제 및 정량목표

〈표 4-15〉 지방자치단체와 중앙정부 문화예산 편성 추이(2011 2021)

〈표 4-16〉 지방자치단체 재정활동별 비중(2021년)

〈표 4-17〉 지방자치단체별 문화예술 예산 비율(2021년 기준)

〈표 4-18〉 지방자치단체 유형별/기능별(분야) 세출비중(2020년)

〈표 4-19〉 지방자치단체 문화재정 재원별 예산규모 추이(2010년 2020년)

〈표 4-20〉 포괄보조 방식 고려 기준

〈표 4-21〉 포괄보조 대상사업 적합성

〈표 4-22〉 전통생활문화 분야 포괄보조사업 제안

〈표 4-23〉 전통생활문화 분야 포괄보조사업 적격성 검토

132

〈표 4-24〉 지역문화 활동인력 지원 분야 포괄보조사업 제안

〈표 4-25〉 지역문화 활동인력 분야 포괄보조사업 적격성 검토

〈표 4-26〉 지역 문화서비스 지원 분야 포괄보조사업 제안

〈표 4-27〉 지역 문화서비스 지원 분야 포괄보조사업 적격성 검토

136

〈표 4-28〉 조사 개요

〈표 4-29〉 조사 문항

138

〈표 4-30〉 응답자의 특성

139

〈표 4-31〉 지역 내 문화사업 관련 조직 및 인력의 기획역량 정도

〈표 4-32〉 사업 추진 시 지역주민의 참여와 의사결정 영향력 정도

〈표 4-33〉 재원교부 절차 및 불용액 관리 방식 적절수준

〈표 4-34〉 집행과정에서 중앙정부의 관리 감독 수준

〈표 4-35〉보조금 지불 정산, 사업 보고 등 행정 및 재정관리 효율 정도

〈표 4-36〉 중앙정부의 성과평가제도의 적절 수준

〈표 4-37〉 중앙정부의 계획과 지자체 정책의 일치 정도

〈표 4-38〉 지자체 계획과 지역 수요의 일치 정도 
〈표 4-39〉 포괄보조형 사업의 지자체 사업추진 자율성, 창의성, 유연성 확보 기여 수준 147 〈표 5-1〉 중앙정부의 지역문화정책 비전 및 목표 154

〈표 5-2〉 문화체육관광부 문화예술정책실 하부 부서별 지자체 국고보조사업(2021년) 155

〈표 5-3〉 지역문화 성과협약형 포괄보조 사업분류(안) 158

〈표 5-4〉 지자체별 재정자립도, 문화예술예산, 문화기반시설 수 168 


\section{그림 목차}

[그림 1-1] 연구의 수행방법 및 과정 6

[그림 2-1] CDBG-DR 프로그램에 의한 지방정부 지원 과정 26

[그림 2-2] 지역문화 생태계 구축 통합운영 시범사업 추진체계 35

[그림 2-3] 국가와 지방자치단체 재정사용액 비교(순계기준) 38

[그림 2-4] 최근 5년간 공모형 국고보조사업의 국고보조율 추이 44

[그림 3-1] 농촌협약 기본 개념도 51

[그림 3-2] 농촌공간 전략계획 및 농촌생활권 활성화계획 개념도 55

[그림 3-3] 지역자율형 사회서비스 투자사업 추진배경 63

[그림 3-4] 지역사회서비스투자사업의 기본 전개 65

[그림 3-5] 지역자율형 사회서비스 투자사업 구조 66

[그림 3-6] 통합건강증진사업 포괄보조 통합 내역 77

[그림 3-7] 지역사회 통합건강증진사업의 비전과 전략 78

[그림 3-8] 지역사회 통합건강증진사업 추진절차 80

[그림 3-9] 지역사회 통합건강증진사업의 구성요소 81

[그림 3-10] 지역사회 통합건강증진사업 성과평가 추진경과 82

[그림 3-11] 지역문화진흥법에 따른 문화도시 지정절차 88

[그림 4-1] 2021년 문화체육관광부의 비전-전략체계 103

[그림 4-2] 전국 문화기반시설 연도별 현황(개) 114

[그림 4-3] 제2차 지역문화진흥기본계획(2020 2024) 116

[그림 4-4] 시도 지역문화진흥 시행계획 워드클라우드 분석(비전, 목표) 117

[그림 4-5] 시도 지역문화진흥 시행계획 워드클라우드 분석(전략) 119

[그림 4-6] 사업추진을 결정, 실행하는데 가장 영향력 있는 주체 140

[그림 4-7] 사업수행을 위한 조직구성 및 대응 체계 141

[그림 4-8] 문화도시조성사업으로 변화된 방향성 143

[그림 4-9] 문화도시조성사업 성과 책임 귀속 주체 143

[그림 4-10] 지자체 문화정책 집중 분야 145

[그림 4-11] 지자체 차원에서 계획 및 관리 필요 분야 146 
[그림 4-12] 지역문화사업의 연계/통합 추진의 중요 요소 146

[그림 4-13] 포괄보조형 사업시 지자체의 어려움 147

[그림 5-1] 생활권-도시권-광역권 포괄보조 전략적 접근 방안 159 

지역문화 성과협약형 포괄보조 방식 도입방안 연구

제1장

서론 



\section{제1절 연구배경 및 목적}

\section{1. 연구배경}

분권의 관점에서 볼 때 지역의 문화진흥은 원칙적으로 지역 여건의 실시간 파악이 가 능하고, 지역 내 가용자원을 직접적이고 효율적으로 동원할 수 있는 지방자치단체가 이 니셔티브를 가지고 추진되어야 한다. 그러나 중앙정부와 지방자치단체 간 재정관계는 개 별 국고보조방식의 공급체계가 고착화되면서 지역문제의 해결 보다는 중앙에서 설계한 사업을 지방자치단체에서 단순히 실행/전달하거나 지방자치단체의 부족한 재정을 보충 하기 위한 예산확보 중심의 보조사업 유치 경쟁에 집중되는 경향이 있다. 특히 문화체육 관광부는 국고보조금 비율은 4번째로 높은 부처이면서 사업개수(내역사업 기준)는 전 부 처 중 가장 많은 소액다건형 사업특징을 가지고 있어 사업체계는 경직되어 있고 행정력 은 크게 소모되고 있다. 국고보조금 비율이 높은 부처들은 중앙정부 의존형, 종속형 특 징이 강화될 수 밖에 없기 때문에 지방자치단체의 재정자율과 책임을 강화할 수 있는 방안을 적극 도입하고 있다. 문화분야처럼 국고보조금이 많은 복지, 농림 분야는 국고보 조금의 포괄화, 지방자치단체 계획에 대한 협약관계 등 중앙정부와 지방자치단체 간 재 정관계를 새롭게 개편하고 있다.

이에 본 연구는 지역 문화정책에서 그간 중앙정부가 기획하고 지방자치단체가 집행하 는 하향식 재정배분의 한계를 개선하고, 동시에 지방자치단체의 문화정책 기획을 중앙과 지방이 협력하는 기능공유 체제로 전환하는 방안을 제안하고자 한다. 이를 국고보조금의 포괄보조 방식에서 성과관리를 강화하는 측면의 의미로 '성과협약형 포괄보조 방식'으로 검토하고자 한다. 정부 간 협약은 행정주체 간의 권한과 역할, 이익, 책임 등을 분명히 하고 협력사항을 사전에 구체화한다는 점에서 분권화에 중요한 수단이며, 기본적으로 예 산지원방식의 변화를 넘어 정부 간 행정관리 및 평가기법 등 성과관리 체계의 개발을 필요로 한다. 


\section{2. 연구목적}

\section{가. 지역문화 성과협약형 포괄보조 방식 필요성 검토}

국고보조사업의 책임성, 효율성 측면에서 쟁점이 발생하면서 지방자치단체의 계획과 재정운영 재량을 확대하는 포괄보조 방식이 등장하였고, 지방자치단체 재정재량에 방점 을 두던 포괄보조 방식은 정부 간 계약과 협상을 강조하는 방식으로 발전되고 있다. 선 행연구와 미국의 포괄보조 변천을 살펴보면서 포괄보조 방식의 순기능과 한계를 분석하 고, 우리나라 지역문화 정책에서 성과협약형 포괄보조 방식의 필요성을 검토한다.

\section{나. 포괄보조사업 성과관리 사례 분석}

최근 국고보조사업 방식이 상향식, 포괄형으로 추진되고 있는 가운데, 농촌협약, 통합 건강증진사업, 지역자율형 사회서비스투자사업 등에서 성과관리 방식을 보완·개편하고 있다. 국내에 추진되고 있는 성과협약형 포괄보조사업의 성과관리 특징과 문체부의 문화 도시조성 사업 시례 분석을 종합하여 지역문화 포괄보조사업에서 성과관리 방안을 검토 한다.

\section{나. 지역문화 성과협약형 포괄보조 기본원칙 및 적용대상 도출}

선행연구를 종합 분석하여 지역문화 성과협약형 포괄보조 기본원칙을 설정하고, 포괄 보조로서의 적격성 검토를 통해 적용대상 사업유형을 도출한다. 이 때 단순히 일부 유사 보조사업단위를 하나의 보조금을 통합하는 포괄보조금이 아닌 지방자치단체 및 현장의 정책을 효과적으로 지원하는 기반 구축을 염두한다.

\section{다. 지역문화 성과협약형 포괄보조 방식 운영방안 제시}

본 연구의 목적은 지역문화사업의 포괄보조 가능성을 진단하고 대상군에 대한 성과협 약 체계를 제안하는 것이다. 협약을 작동하기 위해 블록(Block)으로 묶여 있는 사업을 운영할 수 있는 거버넌스, 협조체계, 재정분담 관계 등을 제시한다. 더불어 협약제도 도 입으로 예상되는 변화에 따른 중앙정부의 단계별 접근방안과 향후 정책과제를 제시한다. 


\section{제2절 연구범위 및 방법}

\section{1. 연구 범위}

\section{가. 시공간적 범위}

본 연구에서 진행된 포괄보조사업 분석 사례의 시간적 범위는 2021년이고, 공간적 범위는 국내1)를 중심으로 하되 일부 미국의 예시를 포함하여 분석하였다. 우리나라의 정부 간 재정관계가 미국 제도의 영향을 많이 받았기 때문에 개념적 이해를 돕는데 일부 내용을 포함하였다. 예산에 대한 분석은 정부예산 기능별 분류 16 개분야 69 개 분류 중 '문화 및 관광' 분야 하부의 '문화예술' 부문을 분석하였고, 정부부처 기준으로는 문화체 육관광부 ‘문화예술정책실' 및 '지역문화정책관' 예산을 분석하였다.

\section{나. 내용적 범위}

연구의 내용적 범위는 크게 다섯 가지로 나뉜다. 첫 번째는 성과협약형 포괄보조 방식 의 개념과 의의에 대한 이해와 지역문화 정책에서 해당 방식 도입 필요성에 대한 검토이 다. 이 과정에서 포괄적 국고보조 방식이 문화분야에 적용되어야 하는 당위성, 협약 방 식의 적용에 있어서 지역문화정책 여건수준에 의문이 없도록 분석하였다.

두 번째는 국내에서 최근 진행되고 있는 국고보조사업에서 협약방식, 포괄보조사업의 성과관리 사례 등 관련된 선행사례에 대한 검토를 수행하였다. 농촌협약, 통합건강증진 사업, 지역자율형 사회서비스투자사업을 대표적으로 살펴보았다. 더해서 문화체육관광 부에서 시도되고 있는 포괄보조방식 사업 사례인 문화도시조성사업 시례의 운영현황도 보았다.

1) 국내에서 성과협약 재정관계는 프랑스의 계획계약(Contrat de plan Etat- Région, CPER)제도를, 포괄보 조는 미국의 사회서비스 포괄보조금(SSBG) 등을 참고하였는데 그동안 다수의 연구에서 해당국가 사례를 설명하고 있으므로, 본 연구에서는 간략히만 다룸 
세 번째는 60년대부터 포괄보조 방식을 추진 및 개편해온 미국에서 활용한 기준과 국내의 농림, 복지 분야에서 활용한 기준을 종합하여 성과협약형 포괄보조 적격기준을 정하고 문화체육관광부 사업에 적용하여 포괄보조 방식 가능성을 검토하였다. 그리고 지 방자치단체 설문조사를 통해 객관적인 지역진단 보충과 협약형 포괄보조방식 도입 시 예상되는 문제점과 준비해야할 사항 등을 확인하였다.

마지막으로 지역문화 성과협약형 포괄보조 방식 도입을 위한 중앙정부와 지방자치단 체의 단계적 접근방안, 성과관리 체계, 이밖에 제도운영 절차 및 세부이행 방식 등을 제 안하였다.

[그림 1-1] 연구의 수행방법 및 과정

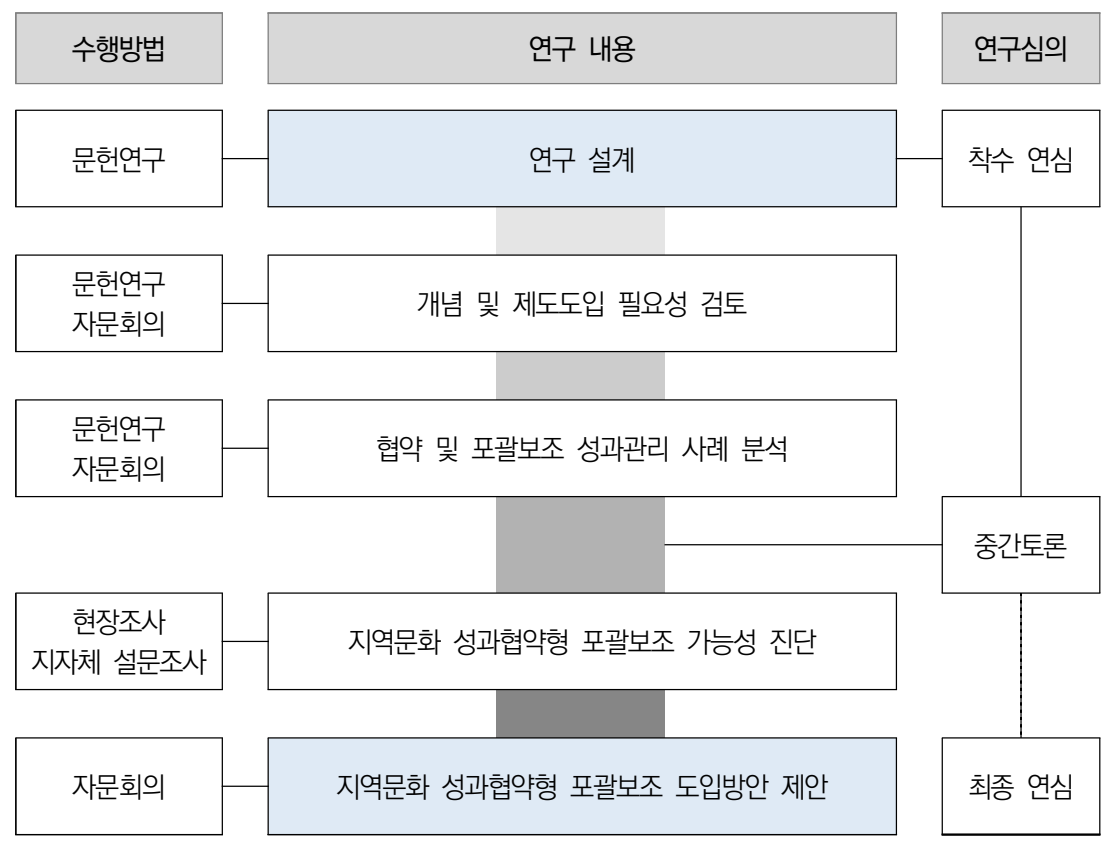




\section{2. 연구 방법}

\section{가. 문헌분석}

정부 간 협약 또는 계약, 국고보조금(포괄보조금) 관련 선행연구, 문화체육관광부 및 지방자치단체 예산서, 사업설명자료 등을 검토한다.

\section{나. 전문가 자문}

분권 및 재정관련 학계 전문가 그룹과 자문회의, 타 분야의 성과협약형 포괄보조 방식 관계자 인터뷰 등을 통해 성과협약형 포괄보조 방식의 문화분야 도입에 실효성있는 방 안을 모색한다.

\section{다. 지자체 관계자 인터뷰}

지방자치단체 현장의 실질적 의견을 확인하기 위해 문화정책에서 포괄보조 방식으로 재정을 지원하고 있는 문화도시사업 관련 지방자치단체 공무원을 대상으로 인터뷰를 실 시하고, 인터뷰 결과를 기반으로 설문문항을 설계한다.

\section{라. 지자체 설문조사}

지역문화 성과협약형 포괄보조와 관련한 사업기획 및 정책과정, 정부 간 관계에 있어 서 지방자치단체 공무원 인식과 현황을 객관적으로 파악하기 위해 지방자치단체 공무원 대상 설문조사를 실시한다. 이를 통해 제도의 전이과정에서 나타날 수 있는 문제를 사전 진단한다. 

지역문화 성과협약형 포괄보조 방식 도입방안 연구

제2장

지역문화 성과협약형

포괄보조 필요성 



\section{제1절 성과협약형 포괄보조의 개요}

\section{1. 국고보조금의 개념}

\section{가. 국고보조금 유형}

1) 이전재원으로서 국고보조금

국고보조금은 중앙정부에서 지출 목적과 대상을 지정하여 지방자치단체로 이전하는 이전재원이다. 지방재정에서 국고보조금은 지방세입인 동시에 세출부문에서 개별적인 지방재정 사업이다. 재정관리와 관련하여 국고보조금 전체를 종합적으로 관리하지 않는 다. 개별 재정사업의 정부간 재정관계 특성에 따른 쟁점들이 전제된다. 따라서 국고보조 사업에 관련된 공공부문 계층간 재정특성들이 다양하게 작용한다.

국고보조금은 지방자치단체의 세입을 보장하는 '지방'의 재원인 동시에 세출에서 지 방자치단체의 윗방향 책임을 보장하기 위한 '중앙' 의 재원이다(이재원, 2016). 중앙정부 각 부처별· 사업별로 국고보조금을 많이 확보하면 지방자치단체 입장에서는 지역사회에 서 공공서비스 확대와 지역문제해결 관련 지출 재원을 확보하는데 유리하다. 재정사업에 서 많은 공공재원은 전국 규모에서 국세의 형태로 동원된다. 따라서 국고보조금은 지방 자치단체의 재정사업에 대한 재원동원에서 지역사회와 갈등을 최소화할 수 있는 유용한 재원이 된다.

국고보조사업의 재정특성은 세 가지 측면이 있다. 하나는 중앙정부가 재정사업을 설 계할 당초 의도한 사업목적 혹은 성과목표를 차질없이 달성하는지에 대한 것으로 재정 사업의 전달체계와 관련된다. 둘째, 국고보조사업을 신청·유치한 지방자치단체 입장에 서 당초 희망대로 국고보조사업이 지역실정에 적합하게 집행될 수 있는지에 대한 것으 로 국고보조사업 집행 지침의 지역 적합성에 대한 것이다. 셋째, 중앙정부의 관리감독 및 재원교부 절차와 일정의 현장 연계와 체계성에 대한 것이다. 


\section{2) 국고보조금의 유형}

(1) '보조금관리에 관한 법’의 유형구분

국고보조사업의 수가 많아지고 실질적인 유형이 다양하지만 재정제도에서는 별도로 독립적인 관리영역을 설정하는 유형구분은 없다. 공식적인 재정제도에서는 '국고보조금' 이라는 하나의 용어에 모든 보조사업이 포함되고 동일한 관리 규정을 적용한다. 국고보 조사업에는 법적 의무성이 강한 국고보조사업(예, 기초연금 등)에서 국가 시책성 재량적 공모사업(예, 지역산업 맞춤형 일자리 등)에 이르기까지 다양하지만 대부분의 국고보조 사업은 지방자치단체의 자율적인 의지에 관계없이 중앙정부 관점에서 추진된다.

기획재정부의 보조금관리에 관한 법에서 국고보조금은 보조금, 부담금, 급부금의 세 가지로 구분한다. 동 법을 제정한 1963 년에 규정됐다. 이 중 지방자치단체에 대하여 교 부하는 보조금·부담금은 「지방재정법」에, 그리고 급부금은「보조금관리에 관한 법률 시 행령」에 그 정의가 제시되어 있다.

부담금은 지방자치단체가 처리해야 할 사무 중 국가와 지방자치단체 간에 이해관계가 있는 경우 원활한 사무처리를 위하여 국가가 부담하는 경비로 정의되어 있다. 급부금은 농가의 소득안정, 영농규모화 촉진, 친환경농업 활성화, 지역활성화, 농촌지역의 경관 형 성 및 관리를 위하여 직접 지급하는 소득보조금을 가리킨다. 그러나 사용목적이 비교적 명확하게 제시된 급부금을 제외하고 협의의 보조금과 부담금은 정의 상 중첩되는 측면 이 있으며, 정책 현장에서 구분을 두고 교부되는 것은 아니다(김우림, 2021).

〈표 2-1〉보조금관리법에서 국고보조금 유형 규정

\begin{tabular}{|c|c|}
\hline 보조금관리에 관한 법 조항 & 비고 \\
\hline $\begin{array}{l}\text { 제2조(정의): “보조금”이란 국가 외의 자가 수행하는 사무 또는 사업에 대하여 } \\
\text { (1) 국가가 이를 조성하거나 재정상의 원조를 하기 위하여 교부하는 보조금, 부담 } \\
\text { 금 그 밖에 상당한 반대급부를 받지 아니하고 교부하는 급부금으로서 대통령령으 } \\
\text { 로 정하는 것을 말한다. }\end{array}$ & \multirow{4}{*}{$\begin{array}{l}\text {-중앙정부의 재정 '조성' } \\
\text { 혹은'원조' 재원으로 규정 } \\
\text {-보조금과 부담금으로 구 } \\
\text { 분. 세부 분류 기준없음 } \\
\text {-보조사업에 부담하는 지 } \\
\text { 방비를 사실상 중앙정부 } \\
\text { 사업재원으로 설정 } \\
\text {-국고보조사업 존속기간 } 3 \\
\text { 년규정에 따라, 지방재정 } \\
\text { 사업의 재원안정성 취약 } \\
\text { 한 상태 지속 }\end{array}$} \\
\hline $\begin{array}{l}\text { 시행령 제2조(급부금의 지정)「보조금 관리에 관한 법률」(이하 “법”이라 한다) 제 } \\
2 \text { 조제 } 1 \text { 호에 따른 보조금·부담금 외의 급부금은 「농산물의 생산자를 위한 직접지 } \\
\text { 불제도 시행규정」제 } 3 \text { 조에 따른 소득보조금으로 한다. }\end{array}$ & \\
\hline $\begin{array}{l}\text { 제 } 13 \text { 조(지방비 부담 의무) 지방자치단체의 장은 보조사업에 대한 지방자치단체 } \\
\text { 의 지방비 부담액을 다른 사업에 우선하여 해당 연도 지방자치단체의 예산에 계 } \\
\text { 상하여야 한다. }\end{array}$ & \\
\hline $\begin{array}{l}\text { 제15조(보조사업의 존속기간과 연장평가) (1) 대통령령으로 정하는 보조사 } \\
\text { 제외한 [보조사업의 존속기간은 3년 이내]로 한다. }\end{array}$ & \\
\hline
\end{tabular}


(2) 지방비 부담의 의무성 정도에 따른 유형구분2)

국고보조금 유형별 재정특성에 대한 별도의 규정은 없다. 민간보조와 국고보조 구분 없이 중앙정부 각 부처가 직접 사업을 수행하지 않고 사업집행을 위탁하면서 재원을 교 부하는 것은 모두 보조금으로 관리한다.

지방자치단체의 지방비 부담의 의무성 정도에 따라 국고보조사업을 분류하고 유형별 로 맞춤형 보조금 관리제도를 도입하면 지방재정 운영에서 중앙정부의 보조사업이 미치 는 왜곡 영향을 적정 수준에서 관리할 수 있는데 다음과 같이 구분할 수 있다.

첫째, (국고부담금) 국가운영을 위한 기본적인 재정기능에 속하는 사업들이 포함된다. 관련 의사결정은 사회적 요구를 수용하여 입법부에서 법률을 통해 제도화된다. 중앙정부 의 법률에서 중앙과 지방이 공동으로 해당 사업에 대한 재원지출을 명시하고 구체적인 분담 비율이 법률조항으로 설정된 사업들로 구성된 유형이다. 둘째, (국고분담금) 법률적 으로 반드시 강제하지는 않지만 중앙정부와 지방정부가 이해관계를 공유하여 공동으로 재원을 마련하는 국고보조사업의 유형이다. 사업을 수행해야할지 여부에 대한 법적 의무 성이 있어도 사업의 규모는 지방자치단체에서 지방비를 매칭하는 범위내에서 결정될 수 있다. 셋째, (국고지원금) 원칙적으로 지방자치단체의 자체사업인데, 중앙정부가 전국 확 산 필요성을 인정하여 사업 조건이 갖춘 지방자치단체에 대해 장려적으로 재원을 교부 하는 사업 유형이다. 넷째, (국고위탁금) 사업의 행정 특성을 고려할 때 국가사무로 수행 되어야 하는 것으로 중앙정부의 소관 부처에서 해당 사업의 집행을 지방자치단체에 위 탁하는 사업 유형이다.

〈표 2-2〉지방비 부담의 의무성 정도에 따른 유형화

\begin{tabular}{c|l|c}
\hline 유형 & \multicolumn{1}{|c}{ 개념 } & 비고 \\
\hline $\begin{array}{c}\text { 국고 } \\
\text { 부담금 }\end{array}$ & $\begin{array}{l}\text { 중앙-지방정부가 공동으로 수행하는 의무사업 } \\
\text { 중앙정부가 지방정부에 이전하는 당연의무 지출 }\end{array}$ & $\begin{array}{c}\text { 법정기준보조율사업, 개별법률 } \\
\text { 근거(국가와 지방자치단체) }\end{array}$ \\
\hline $\begin{array}{c}\text { 국고 } \\
\text { 분담금 }\end{array}$ & $\begin{array}{l}\text { 공동사무로서 상호간 자율 선택성이 부분적으로 인정되는 } \\
\text { 사업에 대한 지출 }\end{array}$ & $\begin{array}{c}\text { 실질적 국가표준적 의무분담 } \\
\text { (중앙과 지방의 이해 공유) }\end{array}$ \\
\hline $\begin{array}{c}\text { 국고 } \\
\text { 지원금 }\end{array}$ & 지방정부 자체사업에 대한 장려적 지출 & $\begin{array}{c}\text { 실질적인 신청주의 적용사업 } \\
\text { (공모과제 등) }\end{array}$ \\
\hline $\begin{array}{c}\text { 국고 } \\
\text { 위탁금 }\end{array}$ & $\begin{array}{l}\text { 중앙정부의 국가사무를 지방정부가 자발적 혹은 법적 의 } \\
\text { 무적으로 위탁 대행 (사무위탁) }\end{array}$ & $\begin{array}{c}100 \% \text { 국고보조 } \\
\text { (위탁수수료-행정관리비용 포함) }\end{array}$ \\
\hline
\end{tabular}

자료: 박병희·이재원·이종하(2020), 국고보조사업 분류체계 개편에 관한 연구. 한국지방재정공제회.

2) 박병희·이재원·이종하(2020) 국고보조사업 분류체계 개편에 관한 연구 내용을 참고하여 작성하였음 


\section{나. 분권국가와 보조사업의 정부간 관계}

국고보조금제도에는 '신청주의'를 적용한다. 국고보조사업은 지방자치단체가 신청을 하면 중앙정부가 해당 사업의 재원으로 용도를 지정하여 지방자치단체에 교부한다. 하지 만 라이트가 유형화한 정부간 관계에서 포함형에 속하는 [국가-지방자치단체]의 수직적 집권체제에서는 상징적인 규정이다.

중앙정부가 국가적 목적으로 재정사업을 설계하고 지방자치단체에게 일정 비율을 의 무적으로 분담하도록 규정할 수 있다. 중앙정부가 국회에서 제정하는 법률을 통해 지방 자치단체의 재정부담을 명기하고 보조율을 설정하면 지방자치단체는 의무적으로 해당 규정을 이행해야 한다. 지방자치단체가 제정하는 조례는 법률의 하위 규정이기 때문에 중앙정부의 법률 규정을 지방자치단체가 위반할 수 없다.

이러한 수직적 정부간 관계에서 국고보조금은 지방자치단체의 신청에 따른 중앙정부 의 재량적인 이전재원이 아니다. 실질적으로는 중앙정부의 재정사업에 대해 지방비 분담 을 의무적으로 설정하는 중앙정부의 재원이다. 이러한 재원에 대한 지방자치단체의 분권 적 재량은 상당히 제한적이다.

중앙정부 각 부처별로 수직계열화된 국고보조사업의 운영체계 혹은 국가서비스의 지 방 전달체계에 잠재된 비효율성과 무책임성 쟁점에 대한 대안은 재정분권의 지방중심 맞춤형 사업 및 재정운영체계를 통한 해결이다.

그런데, [국가-지방자치단체]의 수직 체계에서는 지방자치단체에 대한 일선행정의 재 량을 부여해도 중앙정부의 기대만큼 분권의 효과성이 창출되지 않는다. 사업운영의 권한 -지침-책임이 기본적으로 중앙정부에 귀속되고, 지방자치단체는 중앙부처를 향하는 윗 방향 재정 및 사업책임에 집중하기 때문이다.

문화분권과 같이 지역사회 중심의 문화서비스 다양화를 진흥하기 위해서는 기본적으 로 [국가-지방자치단체]의 정부간 관계가 [중앙정부-지방정부]의 수평적 분권국가체계로 전환해야 한다. 수평적 관계에서 국고보조사업에서는 지방정부의 책임에 기반한 재정신 청에 따라 국비 재원이 교부된다. 사업운영과 재정사업의 성과책임의 주체가 지방정부로 설정되고, 궁극적으로는 '주민방향'의 재정사업 책임체계가 형성된다. 따라서 문화분권 을 통한 지역문화 혁신이 활성화되기 위해서는 정부간 관계에 대한 기본 거버넌스에서 개편이 우선 전제돼야 한다. 


\section{2. 성과협약형 포괄보조의 개념 및 특징}

\section{가. 성과협약형 포괄보조의 개념}

국고보조금은 재량권을 기준으로 개별보조금과 포괄보조금으로 구분할 수 있는데, 포 괄보조금은 특정 서비스 또는 계층에 대해 설계된 사업에 재정이 지원되는 개별보조금 과 달리 넓게 정의된 기능별 목적에 따라 지원되는 재정지원 형태이다. 포괄보조 개념을 행정적 용어로 체계화한 1970년 미국정부간관계위원회(Acvisory Commission on Intergovernmental Relations, ACIR)는 포괄보조를 지방정부가 사업운용에 재량을 가지고 포괄적 영역에 사용될 수 있도록 법적 공식에 따라 배분되는 재원으로 정의하고 있다.

포괄보조 사업은 국가의 정책목표가 설정되고 이와 연계된 지방정부의 사업목표가 설 정되며 지역의 특성과 상황에 맞는 보조사업 형태로 민간단체 등에 지원되는 과정을 거 치며, 주로 협약을 통해 계획을 검토하고 이행을 점검하고 있다. 포괄보조 방식에서 중 앙정부와 지방정부 간 계약(또는 협약)을 통한 협력관계 형성은 매우 중요하다 (Weingast, 2009; Youm and Terman, 2020). 포괄보조는 현실 정책에서 운용하는 실용적인 용어로 제도의 조건과 형태가 다양하게 설계될 수 있는데(이재원, 2009), 본 연구에서는 포괄보조에 있어서 “협약”을 강조하고자 한다.

우리나라에서는 2000년대 중반부터 복지, 농촌 분야를 중심으로 지방자치단체의 재 정적 재량 강화와 분권이 강조되면서 포괄보조 논의가 촉발되었고, 2005년 분권교부세 와 균형발전특별회계가 신설되면서 개념적 의미가 구체화되었다. 균특회계 지역자율계 정의 포괄보조방식은 개별사업의 여러 개 군을 묶어 하나의 포괄보조 블록을 만들고 지 정사업과 지방자치단체 재량을 조합하는 방식이다. 지방자치단체에서는 할당된 총액 재 원 범위와 사업군 내에서 개별 사업에 대한 선택과 재원배분 규모를 결정한다. 이후 결 정된 사업에 대해서는 중앙정부 소관 부처의 사업지침에 따라 관리를 받는다. 세입에서 재량을 확보하고 세출에서는 일반적인 국고보조사업 관리방식을 적용한다. 


\section{나. 포괄보조의 특징}

(1) 중앙정부의 정책성과와 지방정부의 재정활동 재량권 보장

개별 보조나 계약에 의한 보조사업과 달리 국가의 정책 목표를 달성하기 위해 지방정 부가 광범위하게 활동을 수행할 수 있도록 재량을 보장하는 것이 특징적이다. 포괄보조 지원으로 지방정부는 자율성을 가지고 큰 범위(분야) 안에서 지역의 우선순위에 따라 프 로그램을 설계하고 적합한 용처에 자원을 배분하여 사용할 수 있다(Lamia et al., 2020; Jaroscak, Lawhorn and Dilger, 2020; Youm \& Terman, 2020). 특정한 정 책 목표를 달성하기 위해 효율적·효과적으로 재정을 사용하려는 중앙정부와 예산을 지 원받는 과정의 행정적 부담을 최소화하고 지역에 특화된 사업에 예산을 투입하기 위한 지방정부의 능력 사이에서 일어나는 이해관계의 충돌은 포괄보조로 균형을 이룰 수 있 다(Government Accountability Office/GAO, 2014). 이러한 포괄보조는 중앙정부 와 지방자치단체가 기능을 공유하고 지방자치단체의 사업운용 재량을 부여하기 때문에 중앙정부의 표준지침에 의해 지방자치단체가 사업을 집행하는 개별보조 방식보다 분권 적 모델이다.

〈표 2-3〉 분권화와 보조금 특징

\begin{tabular}{|c|c|c|c|c|}
\hline \multicolumn{3}{|c|}{ 강함 — } & 분권의 강도 & $\rightarrow$ 약함 \\
\hline & 구분 & 지방이양 & 포괄보조 & 개별보조 \\
\hline \multirow{4}{*}{$\begin{array}{l}\text { 분권화 } \\
\text { 수단 }\end{array}$} & 분권형식 & $\begin{array}{c}\text { 기능과 재원의 } \\
\text { 완전이양 }\end{array}$ & $\begin{array}{c}\text { 기능의 공유 } \\
\text { 재원의 포괄이양 }\end{array}$ & $\begin{array}{l}\text { 집권방식 유지 } \\
\text { 집행재량 확대 }\end{array}$ \\
\hline & 분권내용 & $\begin{array}{c}\text { 지방의 자주적인 } \\
\text { 재정운용 }\end{array}$ & $\begin{array}{c}\text { 포괄분야 범위 내에서 } \\
\text { 자율운영 }\end{array}$ & $\begin{array}{c}\text { 불용액 인정, 실질적 } \\
\text { 신청주의, 보조율의 } \\
\text { 합리화 }\end{array}$ \\
\hline & \multirow[b]{2}{*}{ 성과책임 } & 지방자치단체 & 중앙.지방 공유 & 중앙정부 \\
\hline & & 자체 성과평가 & $\begin{array}{l}\text { 중앙 성과관리, } \\
\text { 정부간 성과계약 } \\
\text { 의무적 지출규정 }\end{array}$ & $\begin{array}{l}\text { 중앙의 표준 지침관리 } \\
\text { 지방의 집행 과정 책임 }\end{array}$ \\
\hline \multicolumn{2}{|c|}{ 재정책임분담 } & 지방정부 & $\begin{array}{c}\text { 중앙정부 / } \\
\text { 중앙정부+지방정부 }\end{array}$ & 중앙정부+지방정부 \\
\hline \multicolumn{2}{|c|}{ 지방재정유형 } & 자주재원+지방교부세 & $\begin{array}{l}\text { 국고보조금 } \\
\text { (포괄보조금) }\end{array}$ & $\begin{array}{l}\text { 국고보조금 } \\
\text { (개별보조금) }\end{array}$ \\
\hline \multicolumn{2}{|c|}{ 수혜의 성격 } & 자치 서비스 & $\begin{array}{l}\text { 국민의 권리 } \\
\text { 자치 서비스 }\end{array}$ & 국민의 권리 \\
\hline \multicolumn{2}{|c|}{ 개편의 지향가치 } & \multicolumn{2}{|c|}{ 재정분권과 정부간 기능 분담의 재설계 } & 행·재정 관리의 효율성 \\
\hline
\end{tabular}

자료: 이재원(2010) 내용의 일부 재구성 
(2) 협약(Agreement)을 통한 중앙정부-지방정부 간 목표 공유

한국의 포괄보조 제도에 많은 영향을 미친 미국은 60년대부터 포괄보조 제도를 본격 도입하였는데 90년대부터 중앙정부와 지방정부 간 협약을 통한 관계를 중시하기 시작하 였다. 초기 포괄보조 운영에서는(70년대) 중앙정부와 지방정부 간에 표준화된 최적 모형 으로 재정기능 분담이 가능한 것으로 전제하였으나, 80년대 재정적자와 작은정부 상황, 그리고 공공선택이론의 정부실패 비판을 거치면서 중앙정부와 지방정부 간 재정기능 분담에 최적의 구조 전제는 영향력을 잃었다. 90년대 접어들면서 재편된 미국의 정부 간 재정 관계론은 연방정부가 보조사업을 진행할 시 정부 간 계약과 협상을 중요하게 강조하고 있다. 이는 재정기능 분담을 위한 최적구조를 설계하기보다는 공무원의 재정 운영행태, 재정지출 수혜자들의 이기적 행동, 지대추구 등에 대한 논의들을 발전시키는 데 초점을 맞추고 있다(Vo, 2010).

중앙정부와 지방정부 간 관계는 협약 또는 계약, 전략적 계획, 지방자치단체로의 분 권, 조정위원회의 공동참여, 특정지역 전담기구 설치, 예산편성과정 참여 등 다양한 조 정기제와 거버넌스를 통해 현실화된다. 특히 많은 $\mathrm{OECD}$ 국가에서는 중앙정부와 지방 정부 간의 의사결정권, 자금배분(재무약정 포함), 협약을 이행하기 위한 수단 등 상호 의무를 협약(Agreement) 혹은 계약(Contract)3) 하는 방식을 널리 사용하고 있다. 이 러한 중앙정부와 지방정부 간 협약 또는 계약은 국가 차원의 정책 결정과 지역 우선순위 가 일관성을 유지하고 시너지 효과에 기여하도록 하는 역할을 한다. 또한 협약/계약은 보조금보다 폭넓은 범위의 조건으로 협상할 수 있는 기회가 주어지기 때문에 지방정부 는 지역 선호와 특성이 반영된 정책을 추진할 수 있는 특징이 있다(OECD, 2010).

다만 계약/협약 방식은 높은 거래 비용, 상위 정부에 대한 권력 편향 또는 모든 당사 자에 적용하기에는 불충분한 평가 절차 등의 한계점이 존재하고 있으며, 일부 국가에서 는 협약/계약을 위한 비용 급증과 거버넌스의 복잡성 문제가 나타나고 있다(OECD, 2007). 프랑스의 감사원은 다양한 유형의 계약이(예: urban, city, agglomeration, metropolitan, and state-region) 전체 시스템을 매우 복잡하게 만들고 책임성을 낮 게 한다는 지적을 하였다.

3) 한국의 경우 협약/계약 방식보다 정부의 목표를 제시한 전략적 계획수립을 통한 관계 형성하고 있음 
〈표 2-4〉 OECD 국가의 중앙-지방 정부 간 협력방식 유형

\begin{tabular}{|c|c|c|c|}
\hline 구분 & 국가수 & 국가명 & 주요 수단 \\
\hline \multirow{15}{*}{$\begin{array}{c}\text { 협약/계약, } \\
\text { 일부 공동자금 }\end{array}$} & \multirow{15}{*}{15} & 오스트리아 & 다자간 및 양자간 협약 \\
\hline & & 캐나다 & 연방-지방 상호협정, 연방-지방 공동 자금 조달 \\
\hline & & 칠레 & 계획 협약 \\
\hline & & 덴마크 & 파트너십 협약 \\
\hline & & 프랑스 & 중앙-지방 프로젝트 계약 \\
\hline & & 아이슬란드 & 지역성장 협약 \\
\hline & & 이탈리아 & 기관협약 및 프레임워크 프로그램 협약 \\
\hline & & 룩셈부르크 & 관습화된 비공식적 협약(도시 지역) \\
\hline & & 멕시코 & 분권 협약 \\
\hline & & 네덜란드 & 도시 및 농촌 계약 \\
\hline & & 폴란드 & 지역 계약, 권역(영토) 계약 \\
\hline & & 포르투갈 & 시 협회의 글로벌 보조금 \\
\hline & & 스페인 & 협력 협약 \\
\hline & & 스위스 & 4년 공동 프로그램 협약 \\
\hline & & 영국 & 지역경제 성과 공공서비스 협약 \\
\hline \multirow{9}{*}{$\begin{array}{c}\text { 정부목표 } \\
\text { 제시/전략적 계획 } \\
\text { (법적 시스템) }\end{array}$} & \multirow{9}{*}{9} & 체코 & 공간개발 정책 \\
\hline & & 일본 & 국가 공간전략 및 지역 공간전략 \\
\hline & & 한국 & 국토종합계획, 지역발전 5개년 계획 \\
\hline & & 룩셈부르크 & 지역 계획 \\
\hline & & 멕시코 & 계획 시스템 \\
\hline & & 포르투갈 & 지역 공간계획 \\
\hline & & 슬로바키아 & 공간계획 프로세스 \\
\hline & & 스위스 & 공간계획 연방법 \\
\hline & & 영국 & 지역개발청(RDAs)의 국가 성과 목표 수립 \\
\hline \multirow{7}{*}{ 지역으로의 분권 } & \multirow{7}{*}{7} & 캐나다 & 지역개발 기관(1980년대 중반), 연방 지역 협의회 \\
\hline & & 칠레 & 지역개발 기관(2006-7), 권역관리 프로그램 \\
\hline & & 핀란드 & 지방자치단체와 지역관리위원회의 조정 \\
\hline & & 프랑스 & 지역 Préfet's(도지사)의 조정 \\
\hline & & 노르웨이 & 이노베이션 노르웨이(국영기관) \\
\hline & & 포르투갈 & 지역협력개발위원회 \\
\hline & & 영국 & 영국의 지역개발청 \\
\hline \multirow{6}{*}{$\begin{array}{r}\text { 조정 위원회 } \\
\text { 공동 참여 }\end{array}$} & \multirow{6}{*}{6} & 호주 & 지역개발위원회, 호주 지역개발 \\
\hline & & 오스트리아 & 오스트리아 공간계획회의, ÖROK \\
\hline & & 독일 & 지역경제구조개선을 위한 공동과제 조정, 다년 조정 프레임워크 \\
\hline & & 노르웨이 & 연간 계약회의 및 기타 회의 \\
\hline & & 스페인 & 지자체 장 회의, 부문별 협력회의, 지역발전협의회 \\
\hline & & 스웨덴 & 국가포럼 및 주제별 그룹 \\
\hline \multirow{4}{*}{$\begin{array}{c}\text { 지방장관, } \\
\text { 지역전담부서 }\end{array}$} & \multirow{4}{*}{4} & 캐나다 & 지방 장관 \\
\hline & & 프랑스 & 권역개발, 수도권 지역만 해당 \\
\hline & & 네덜란드 & Randstad 지역만 해당 \\
\hline & & 영국(잉글랜드) & 잉글랜드만 해당 \\
\hline \multirow{2}{*}{$\begin{array}{c}\text { 목표설정과 } \\
\text { 재정유인 }\end{array}$} & \multirow{2}{*}{2} & 이탈리아 & 성과준비 시스템 \\
\hline & & 스위스 & 4년 공동프로그램 협약(보상 및 성과목표) \\
\hline \multirow{2}{*}{$\begin{array}{l}\text { 예산편성 } \\
\text { 과정 참여 }\end{array}$} & \multirow{2}{*}{2} & 핀란드 & 예산편성 과정 \\
\hline & & 네덜란드 & 경제부처의 공간경제정책국 \\
\hline
\end{tabular}

주: 일부 국가는 유형이 중복 해당됨

자료: OECD(2010), Regional Development Policies in OECD Countries 


\section{3. 성과협약형 포괄보조 방식 사례(미국)4)}

\section{가. 도입배경 및 현황}

\section{1) 도입배경}

미국은 1960년대와 1970년대에 걸쳐 보조금제도에 많은 변화가 있었는데 전통적인 보조금 지원방식인 범주형 보조금(Category Grants)의 비효율성이 지적되면서 포괄보 조금(Block Grants)이 등장하였다.

최초의 포괄보조 형식은 사회서비스와 보건정책을 중심으로 1966년부터 추진되었고, 제도도입 이전 20여년 기간동안 의회에서 관련내용의 입법제안이 있었다. 1946년 당시 노후 지원, 부양자녀 부조, 시각장애인 등 범주형 보조사업(Category Grants)을 지방정 부(주정부) 결정으로 개별 실시 혹은 종합지원 프로그램 설계가 가능하도록 하는 내용의 「공공복지법」 제정안이 발의되었다. 이후 1947 년 정부조직 개편을 위한 위원회5)에서 단편·분절적인 보조사업에 대하여 도로, 교육, 공공지원, 공공보건과 같은 광범위한 범 주에 기초한 보조금 시스템을 확립할 것을 권고하였다.

그러나 의회는 이러한 제안에도 불구하고 계속 포괄보조 방식의 사업을 승인하고 있 지 않다가 1966년 통합 건강지원 서비스(Comprehensive health care services)6)를 시행하여 9개의 범주형 보조(Formula categorical grants)사업을 포괄보조로 지원하 였다. 2년 후에는 범죄 통제(Crime Control) 또는 안전한 거리(Safe Streets) 프로그램 으로 불리는 두 번째 포괄보조 사업을 시행하였다. 두 보조사업의 예산은 지방정부에 대한 당시 연방정부 예산의 $1 \%$ 미만을 차지하였다(Jaroscak, 2021; Finegold, Wherry, and Schardin, 2004).

1966년 처음 도입된 포괄보조금은 지속적으로 증가하여 2012년에는 26개로 늘어났 고 2020년 기준 21개가 운영되고 있다.

4) 한국의 정부 간 재정관계는 미국의 재정연방주의 이론(대표적인 예로 작은 정부, 정부의 재정기능, 최적보 조율 논의 등)의 영향을 많이 받았으므로, 개념적 이해를 돕기위해 미국의 사례를 일부 작성하였음

5) 트루먼 대통령 지시에 따라 전임 대통령인 후버를 위원장으로 하는 정부조직 개편 위원회, Commission on the Organization of the Executive Branch of the Government

6) 현재의 예방적 건강서비스 포괄 보조(the Preventive Health and Health Services Block Grant) 


\section{2) 포괄보조 목적}

미국에서 포괄보조 제도를 정부간 관계에 적용한 것은 시기적으로 세 가지로 구분할 수 있고 포괄보조프로그램의 목적을 행정관리 효율화, 중앙재정부담의 전가, 정부간 성 과계약, 재정사업에 대한 재원보장 등의 네 가지로 정리할 수 있다.

첫째, 소규모 영세 보조금들의 재정관리에서 창출되는 행정관리의 비효율성 문제를 해결하는 방안으로 50년대 후버위원회의 정부혁신 제안에 기초한 포괄보조제도는 영세 보조금을 통하여 대규모 재정단위의 연방예산사업을 설계하는 것이다.

둘째, 80년대 연방정부의 재정위기에 대한 대응의 일환으로 주 및 지방정부에 교부하 는 보조금의 총액을 축소하는 대신 개별 사업에 대한 재원배분 재량을 확대한 레이건정 부의 포괄보조제도가 있었다. 연방정부 복지재정부담의 지방전가 목적이 있었고, 복지사 업의 책임을 주 및 지방정부에 이전하면서 신재정연방주의 체제를 구축했다.

셋째, 90년대 접어들면서 연방정부의 재정상태가 양호한 가운데 사회복지사업에서 결과지향적 성과혁신을 위해 정부간 성과계약체제의 재정수단으로서 설계한 포괄보조제 도가 있다. 아동복지사업의 개별 프로그램들을 통합하여 아동부양자의 일자리 참여를 유 도하는 클린턴 행정부의 TANF(Temporary Assistance to Needy Families) 프로그 램이 대표적이다. 여기에서는 재정인센티브와 벌칙 등의 전략적인 재정관리 조치들이 있 다. TANF 프로그램은 성과지표의 설정에서부터 프로그램 관리의 틀과 원칙, 최종적 성과에 기반 한 재정인센티브 부여 방식에 이르기까지 주정부와의 논의를 통해 합의를 통해 도출하였다. 각 지방이 처한 현실의 차이를 성과계약에서 가능한 반영할 수 있도 록 함으로써, 중앙정부는 반드시 지켜야할 대 원칙을 고수하면서도 지방자치단체의 협 조를 얻어낼 수 있었다(한국지방세연구원, 2018)

시기와 상관없이 연방정부로부터 주 및 지방정부로 일반재원의 특성이 강한 포괄보조 프로그램들이 있다. 지역개발분야의 $\mathrm{CDBG}$ (지역개발포괄보조)와 사회복지분야의 SSBG (사회서비스포괄보조)가 대표적이다. 미국 연방정부에서는 지출조건에 제한이 없는 보통 교부세와 같은 일반재원 형식의 이전재정이 없다. 대신 CDBG와 SSBG 등과 같이 포괄 적인 재정지출 범위를 설정하고 주 및 지방주의 지출재량을 포괄적으로 부여하는 재원 보장형 포괄보조 프로그램들을 운영한다. 


\section{3) 포괄보조 프로그램 현황}

2020년 기준으로 21 개 584억 달러의 포괄보조 사업이 있으며 전체 연방정부 보조사

업 예산의 7.4\%를 차지하고 있다(Jaroscak, Lawhorn and Dilger, 2020).

〈표 2-5〉2020년도 미국 연방정부의 Block Grant 예산

(단위: US달러(\$))

\begin{tabular}{|c|c|c|}
\hline 연방정부 & Block Grant 프로그램 & 2020년 예산 \\
\hline $\begin{array}{c}\text { Department of } \\
\text { Education }\end{array}$ & Innovative Education Program Strategies Block Grant & $\begin{array}{l}\text { Not currently } \\
\text { funded }\end{array}$ \\
\hline $\begin{array}{c}\text { Department of } \\
\text { Energy }\end{array}$ & Energy Efficiency and Conservation Block Grant & $\begin{array}{l}\text { Not currently } \\
\text { funded }\end{array}$ \\
\hline \multirow{10}{*}{$\begin{array}{l}\text { Department of } \\
\text { Health and } \\
\text { Human Services }\end{array}$} & $\begin{array}{l}\text { Child Care and Development Block Grant }(\$ 5.826 \text { billion } \\
\text { in CCDBG (discretionary) funding and } \$ 2.917 \text { billion in } \\
\text { Child Care Entitlement to States (mandatory) funding) }\end{array}$ & $\$ 8,743,000,000$ \\
\hline & Community Mental Health Services Block Grant & $\$ 722,571,000$ \\
\hline & Community Services Block Grant & $\$ 740,000,000$ \\
\hline & Low Income Home Energy Assistance Block Grant & $\$ 3,740,304,000$ \\
\hline & Maternal and Child Health Services Block Grant & $\$ 687,700,000$ \\
\hline & Preventive Health and Health Services Block Grant & $\$ 160,000,000$ \\
\hline & Social Services Block Grant & $\$ 1,700,000,000$ \\
\hline & Substance Abuse Prevention and Treatment Block Grant & $\$ 1,858,079,000$ \\
\hline & Temporary Assistance to Needy Families & $\$ 16,434,254,853$ \\
\hline & Title V Sexual Risk Avoidance Education & $\$ 35,000,000$ \\
\hline $\begin{array}{l}\text { Department of } \\
\text { Homeland } \\
\text { Security }\end{array}$ & $\begin{array}{l}\text { Homeland Security Grant Programs (State Homeland } \\
\text { Security Programs, Urban Area Security Initiative Grant, } \\
\text { and Operation Stonegarden) }\end{array}$ & $\$ 1,225,000,000$ \\
\hline \multirow{6}{*}{$\begin{array}{l}\text { Department of } \\
\text { Housing and } \\
\text { Urban } \\
\text { Development }\end{array}$} & Community Development Block Grant & $\$ 3,425,000,000$ \\
\hline & Indian Community Development Block Grant & $\$ 70,000,000$ \\
\hline & Emergency Solutions Grant Program & $\$ 290,000,000$ \\
\hline & HOME Investment Partnerships Program & $\$ 1,350,000,000$ \\
\hline & Native American Housing Block Grant & $\$ 646,000,000$ \\
\hline & Native Hawaiian Housing Block Grant & $\$ 2,000,000$ \\
\hline $\begin{array}{l}\text { Department of } \\
\text { Justice }\end{array}$ & Edward Byrne Memorial Justice Assistance Grant & $\$ 547,210,000$ \\
\hline $\begin{array}{c}\text { Department of } \\
\text { Labor }\end{array}$ & $\begin{array}{l}\text { Workforce Innovation and Opportunity Act } \\
\text { (Youth, Adult, and Dislocated Workers) }\end{array}$ & $\$ 2,819,832,000$ \\
\hline \multirow{2}{*}{$\begin{array}{l}\text { Department of } \\
\text { Transportation }\end{array}$} & $\begin{array}{l}\text { Federal Aviation Administration Airport Improvement } \\
\text { State Block Grant Program }\end{array}$ & $\$ 252,483,939$ \\
\hline & Surface Transportation Program & $\$ 12,918,130,523$ \\
\hline \multicolumn{2}{|r|}{ Total Funding } & $\$ 58,366,565,315$ \\
\hline
\end{tabular}

자료: Jaroscak, Lawhorn and Dilger(2020), Block Grants: Perspectives and Controversies", Congressional Research Service 


\section{나. Community Development Block Grants(CDBG)7)}

1) 개요

Community Development Block Grants(CDBG)는 1974년부터 주택도시개발부 (U.S. Department of Housing and Urban Development/이하 HUD)의 경제개발, 지역사회개발 및 기반시설 건설 분야에 대한 포괄보조 사업으로 기초자치단체(Cities, Counties) 단위에 현재까지 1,600 억 달러이상의 연방 예산을 지원해오고 있다 (Jaroscak, 2021). 1980년대 초반 가장 많은 예산을 배분하였던 CDBG 프로그램 예산 은 감소 추세를 보이고 있으며, 2020년에는 3,425백만달러의 예산이 책정되었다.

연방정부는 포괄보조의 성격을 구현하기 위해 특정활동 범주 내에서는 지방정부에게 상당한 재량권을 부여하고 있다. $\mathrm{CDBG}$ 에 의해 지방정부로 지원되는 예산은 각 지방정 부에서 유연하게 예산을 활용할 수 있도록 하고 있으며 대체로 기획.행정 활동, 공공사 업이나 시설, 주택관련 활동, 공공 서비스, 경제 개발, 부동산의 취득, 처분 등을 수행한다.

다만, 지방정부는 각각의 보조사업 활동이 법령에 명시된 국가 정책목표에 부합한다는 것을 계획이나 결과 보고를 통해 제시해야 한다. 원칙적으로 저소득 및 중소득 개인에 대한 혜택, 빈민가의 예방 또는 해소 지원, 주민의 건강과 안전에 심각하고 즉각적인 위협을 해소하여 긴급한 요구 충족을 위해 사용되어야 한다. $\mathrm{CDBG}$ 를 주관하는 $\mathrm{HUD}$ 는 '기본적 으로 저소득층 및 중산층을 위해 적절한 주택과 주거환경을 제공하고 경제적 기회 확대를 통해 실현 가능한 도시 공동체를 개발하는 것' 으로 프로그램의 목표로 밝히고 있다(U.S. Department of Housing and Urban Development, 2013; Wiley, 2014).

한편 $\mathrm{CDBG}$ 프로그램의 추가 지출로 경제적 위기, 공중보건 비상, 재해 등에 대비하 여 주와 카운티를 지원하기 위한 예산을 마련하고 있는데, 추가지출은 필요한 경우 특정 주에 대해서만 금액을 확정한다. 예를들어 재난극복을 위한 특별보조사업(Disaster Recovery, CDBG-DR)이 대표적이다.

7) 앞서 언급한 바와 같이 2020년 기준으로 21 개 포괄보조 사업이 있으나, 문화분야에도 지원이 된 것으로 조사된 $\mathrm{CDBG}$ 에 대하여 사례 분석하였음 


\section{2) 포괄보조 방법8)}

(1) 예산 수립 및 배분, 성과관리

정부가 제출한 예산안에 대하여 의회가 의결하게 되면 중앙정부에서는 관보에 해당 내용을 공고하고 지원대상에 대하여 관련 문서를 준비하여 정해진 기한 내 제출할 것으 로 요구한다. 지방정부의 계획에 대한 승인과 사업시행 이후부터 중앙정부는 보조금을 받은 지방정부의 활동과 지출 내역 및 성과를 감독하고, 지방정부는 예산 지출의 기록과 함께 연간 재정보고서와 사업 성과보고서를 중앙정부에 제출해야 한다.

의회는 $\mathrm{CDBG}$ 예산이 적절하게 사용되었는지와 예산의 배분 방법의 개선과 같은 문 제에 대하여 정기적인 청문회를 열어 프로그램 전반을 감독하고, 미국 회계감사원(U.S. Government Accountability Office/GAO)에 의뢰하여 프로그램 평가의 품질, 지방 정부의 의무 준수, 배분 방법 등에 대한 보고서를 검토한다.

$\mathrm{CDBG}$ 는 〈표 2-6)과 같은 과정으로 예산 편성 및 성과관리 하고 있다.

〈표 2-6〉 $\mathrm{CDBG}$ 의 예산수립과 실행과정 개요

\begin{tabular}{|c|c|c|c|}
\hline 구분 & $\begin{array}{c}\text { 의회 } \\
\text { (Congress) } \\
\end{array}$ & $\begin{array}{l}\text { 중앙정부 } \\
\text { (HUD) }\end{array}$ & $\begin{array}{c}\text { 지방정부 } \\
\text { (Grantee) }\end{array}$ \\
\hline (1) 예산(Appropriation) & $\checkmark$ & & \\
\hline (2) 배분과정(Allocation Process) & & $\checkmark$ & \\
\hline $\begin{array}{l}\text { (3) 사업계획 제출 } \\
\text { (Consolidated and Annual Action Plan Submission) }\end{array}$ & & & $\checkmark$ \\
\hline $\begin{array}{l}\text { (4) 계획 승인 및 의무 확인 } \\
\text { (Plan Approval and Fund Obligation) }\end{array}$ & & $\checkmark$ & $\checkmark$ \\
\hline $\begin{array}{l}\text { (5) 사업 시행 } \\
\text { (Activity Implementation) }\end{array}$ & & & $\checkmark$ \\
\hline $\begin{array}{l}\text { (6) 성과 점검 } \\
\text { (Performance Monitoring) }\end{array}$ & & $v$ & $v$ \\
\hline $\begin{array}{l}\text { (7) 프로그램 감독 } \\
\text { (Program Oversight) }\end{array}$ & $v$ & $v$ & \\
\hline
\end{tabular}

8) Jaroscak(2021) Support Local Development and Infrastructure Projects Through the Community Development Block Grant (CDBG) Program을 참고하여 작성 
(2) 지방정부의 통합계획 수립, 3 5년 중기계획 제출

지방정부가 $\mathrm{CDBG}$ 의 예산을 지원받기 위해서는 통합계획 과정(Consolidated Plan Process)에 참여해야 하는데, 중앙정부에서는 지역사회 개발 및 주택과 관련한 조건이 나 필요성을 평가하여 프로그램 선택 여부를 통지한다. 이 과정에서는 지방정부는 커뮤 니티 참여를 포함하여 $\mathrm{HUD}$ 의 조건을 준수하는 연간전략계획과 3 5년의 통합계획을 함께 제출해야 한다. 또한, 기존에 지원받은 지방정부는 전년도 목표에 대한 성과를 제 출해야 한다. 사업시행단계에서 지원받는 주정부나 카운티정부가 재배분할 경우 활용할 수 있는 협약(Agreement)의 샘플을 제공하고 있으며, 주정부에 따라 계약(Contract)의 명칭을 사용하는 경우도 있다.

(3) 사업 성과의 공개와 환류

중앙정부는 각 지방정부에서 보고된 결과를 공개하고 있는데, $\mathrm{CDBG}$ 프로그램의 경 우 사업분야(주택, 경제개발, 공공서비스 등)와 지원받은 가구, 일자리, 개인의 수를 공 개하고 있다. 가시적인 성과에 대한 비판이 있어 이에 대하여 사업추진 역량을 강화하고 좋은 성과를 내는 지역에 대한 보상, 우수사례에 대한 공유와 함께 $\mathrm{CDBG}$ 프로그램에 참여를 유도하고 가능한 단체들에 대한 교육을 위한 별도 예산을 편성하고 있다.

\section{3) 보조금 배분공식}

(1) 지역 규모에 따라 배분공식 차등 적용

지역의 인구규모를 기준으로 보조금 배분공식 적용방식 및 주체가 다른데 인구 20만 명 이상의 County와 5만명 이상의 City를 법정교부지역(Entitled Communities), 그 이하의 소도시를 법정교부지역(non-entitlement communities)로 구분하고 있다.

전체 예산의 70\%는 법정교부지역(Entitled Communities)에 배분되고 연방정부가 직접 편성하고 나머지 30\%는 비법정교부지역(non-entitlement communities)에 배 분되고 주정부가 편성한다.

(2) 인구, 빈곤도, 주택과밀 비율에 따라 예산배분률 적용

법정교부지역(Entitled Communities), 비법정교부지역(non-entitlement communities) 모두 Formula A, Formula B로 불리는 2가지 유형의 배분공식이 제공되는데 산정기준 
은 인구, 빈곤도, 주택과밀 비율 등이다. Formula A는 관할 구역의 인구 비율, 빈곤층, 과밀 주택 단위를 기반으로 하는 반면 Formula B는 1960년 이후의 인구 증가 지연, 빈곤층 및 1940 년 이전에 지어진 주택 수를 기반으로 한다. 각 지역은 자치단체에 유리 한 유형을 선택할 수 있다.

법정교부지역(Entitled Communities) 대상 첫 번째 유형(Formula A)은 인구 25\%, 빈곤도 $50 \%$, 주택 과밀도 $25 \%$ 에 대하여 해당지역별 가중된 비율에 기초하여 예산을 배분한다. 여기서 빈곤도는 연방 수준의 빈곤도 수준 또는 그 아래에서 측정된 인구로 표현되고, 주택 과밀은 1 개 방당 1.01 명 이상의 가구단위로 정의된다. 두 번째 유형 (Formula B)은 인구 증가율 지연 20\%, 빈곤도 30\%, 1940년 이전에 건설된 주택 50\% 에 대하여 해당지역별로 가중된 비율에 기초하여 예산을 배분한다. 인구 증가 지연은 해당 기간의 모든 entitlement communities와 비교하여 1960년과 가장 최근의 인구 조사 사이의 증가율을 계산하여 산출한다.

비법정교부지역(non-entitlement communities)은 주정부에서 예산을 재배분한다. 예산배분 기준은 비법정교부지역(non-entitlement communities) 해당 주의 인구, 빈 곤도, 주택과밀 비율에 기초하게 된다. 첫 번째 유형(Formula A)은 인구 25\%, 빈곤도 $50 \%$, 주택 과밀도 $25 \%$ 에 대하여 해당 주 지역의 가중된 비율에 기초하여 예산을 배분 한다. 두 번째 유형(Formula B)은 인구 20\%, 빈곤도 30\%, 1940년 이전에 건설된 주택 $30 \%$ 에 대하여 주별 가중된 비율에 기초하여 예산을 배분한다.

〈표 2-7〉 CDBG의 예산 배분 공식

\begin{tabular}{|c|c|c|c|}
\hline \multicolumn{2}{|c|}{ Entitlement } & \multicolumn{2}{|c|}{ non-entitlement } \\
\hline Formula A & Formula B & Formula A & Formula B \\
\hline $\begin{array}{l}0.25 \text { (인구/총인구) } \\
0.50 \text { (빈곤도/총 빈곤도) } \\
0.25 \text { (과밀도/총 과밀도) }\end{array}$ & $\begin{array}{l}0.20 \text { (인구증가 지연/총 } \\
\text { 인구증가 지연) } \\
0.30 \text { (빈곤도/총 빈곤도) } \\
0.50 \text { (1940년 이전 } \\
\text { 주택수/총 주택수 }\end{array}$ & $\begin{array}{l}0.25 \text { (인구/총인구) } \\
0.50 \text { (빈곤도/총 빈곤도) } \\
0.25 \text { (과밀도/총 과밀도) }\end{array}$ & $\begin{array}{l}0.20 \text { (인구/총인구) } \\
0.30 \text { (빈곤도/총 빈곤도) } \\
0.50 \text { (1940년 이전 } \\
\text { 주택수/총 주택수) }\end{array}$ \\
\hline
\end{tabular}

주: 총 주택수 역시 1940년 이전에 건설된 주택의 총수를 의미함

자료: Jaroscak(2021), Support Local Development and Infrastructure Projects Through the Community Development Block Grant (CDBG) Program, 2021 Policy Brief 


\section{나. CDBG-DR(Community Development Block Grant-Disaster Recovery)}

1) 배경

CDBG-DR(Community Development Block Grant-Disaster Recovery)는 1974년부터 주택, 경제 개발, 지역사회 활동 등에 있어서 재난극복에 대한 포괄지원을 추진하고 있다. 태풍(허리케인)이나 기타 자연재해로 발생한 국지적인 재난에 대하여 의 회는 예산의 추가 편성을 의결하여 지역 사정에 맞는 활동을 지원하고 있다. 예를 들어 주택이 없어진 경우 이주비 지급, 재산손실에 대한 보상, 피해주택의 복구, 근린센터 또 는 도로 등 기반시설 건설·복구 등에 대하여 지방정부가 재량권을 가지고 예산을 집행할 수 있도록 하고 있다(GAO, 2019). 2017년 허리케인으로 인해 막대한 피해가 발생한 4 개 지역(플로리다, 텍사스, 푸에르토리코, 버진아일랜드)에 대하여 CDBG 프로그램을 활용하여 재난구호를 위한 포괄보조사업을 추진하였다. 지방정부별로 필요한 곳에 중앙 정부의 재정을 사용할 수 있는 장점을 가지고 있으며 경우에 따라 특정 주만 지정하여 포괄보조 사업을 추진하는 경우도 있다.

\section{2) 포괄보조 방법9)}

(1) 예산수립 및 배분, 성과관리

중앙정부는 예산이 확정되면 포괄보조 대상 지역과 예산액 등을 공고하고 지방정부는 과정과 절차, 역할이 포함된 이행계획 및 수요분석을 포함한 세부계획을 제출하여 중앙 정부의 심사를 받는다. 계획이 승인되면 중앙정부와 지방정부는 보조급협약을 체결한다.

[그림 2-1] CDBG-DR 프로그램에 의한 지방정부 지원 과정

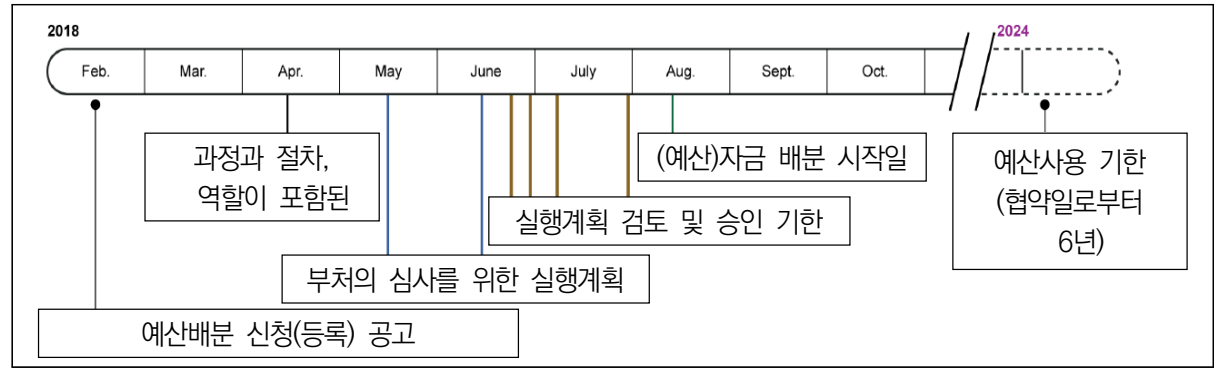

자료: GAO(2019), DISASTER RECOVERY: Better Monitoring of Block Grant Funds Is Needed

9) 2017 년 당시의 허리케인으로 인한 4 개 지역의 재난구호를 위한 포괄보조사업의 과정을 참고하여 작성 
(2) 지방정부의 조직구성 및 수요분석, 실행계획 수립

지방정부(지역)에서는 CDBG-DR 프로그램에 대하여 4개 지역에서는 재난 극복을 위 한 사업을 수행할 수 있는 여건, 역할 등을 포함한 사업 이행계획을 제출한다. 동시에 해당 사업에 대한 재정적인 관리, 조달 과정, 보조금 사용 관리체계(중복수급 방지, 적기 지출, 부정사용 예방 포함)를 문서화한다. 중앙정부는 예산을 집행할 인적자원과 집행조 직의 역량 등을 자체적으로 평가하도록 안내하고 지방정부에서는 해당 사업을 수행하고 예산을 집행하기 위한 조직 구조를 적절히 조정한다.

이후 주거, 기반시설, 경제 활성화에 대한 미충족 수요(unmet needs)10) 파악이 포함 된 실행계획을 제출하고 연방정부의 심의를 받는다. 미충족 수요에 대한 파악 내용을 포함시키게 하는 이유는 지역사회의 니즈(needs)를 사전에 파악하고 배분될 예산을 가 장 필요한 곳에 사용하게하기 위해서이다.

(2) 보조금 협약 체결

이러한 이행 계획과 실행 계획이 제출되고 중앙정부 HUD(Department of Housing and Urban Development)에서 검토 및 승인한 이후에 보조금 협약(grants agreement) 을 체결하게 되고 그로부터 정해진 기간(이 사업의 경우는 6년)동안 지방정부에서 유연 하게 사업 예산을 사용할 수 있게 된다. 다만 중앙정부(HUD)의 검토 과정에서 사용하는 체크리스트가 재난극복 지원을 위한 적절한 자원을 구분하는 것에 대한 질문이 없거나 '예/아니오' 문항으로 구성되어 있고 특정 단어(adequate control)에 대한 명확한 정의 가 없는 등 평가체계의 적절성과 내부지침 필요성에 대해 미국 감사원의 지적이 있었다 (GAO, 2017).

중앙정부(HUD)는 지방정부에 대하여 포괄적인 사용처 등을 포함한 최종 배정 예산을 통보하고 예산을 지원하는데, 통보문서에는 본문과 협약, 그리고 부록으로 구성되어 있 다. 대체로 다음과 같은 내용이 포함된다.

10) 미충족 수요에 대해서 보험이나 다른 형태의 지원에 의해 충족되지 않은 손실(losses not met with insurance or other forms of assistance)이라고 명확히 정의하고 있음(GAO, 2019) 
〈표 2-8〉 CDBG-DR 지원 결정통보문 (루이지애나주(Louisiana) 대상, 2017)

\begin{tabular}{|c|c|c|}
\hline 구분 & 내용 & 비고 \\
\hline (1) 지원예산 총액 & $\begin{array}{l}\text { - } \$ 1,219,172,000 \text { 지원 통보 } \\
\text { - 기존 CDBG 예산 }(\$ 437,800,000) \text { 에 } \\
\text { 해당 지원금이 더해짐을 명시 } \\
\text { (총 } \$ 1,656,972,000)\end{array}$ & $\begin{array}{l}\text { - 지역을 특정하여 최소 } 80 \% \text { 의 자금이 } \\
\text { 해당 지역에 사용되어야 함을 명시 } 111)\end{array}$ \\
\hline (2) 예산 사용 대상 & $\begin{array}{l}\text { - 재난 구호, 기반시설의 장기간 복구, 주 } \\
\text { 택, 피해가 가장 큰 지역의 재건으로 한 } \\
\text { 정함을 명시 }\end{array}$ & $\begin{array}{l}\text { - 예산 사용의 근거가 되는 법률(2개)을 명 } \\
\text { 시하여 해당 법률에서 제시되지 않은 사 } \\
\text { 업에 대해서는 사용하지 못하도록 규정 }\end{array}$ \\
\hline $\begin{array}{l}\text { (3) 프로그램별 예산 } \\
\text { 배분 }\end{array}$ & $\begin{array}{l}\text { - 지원 분야별로 예산을 배분하여 명시 } \\
\text { - 주택 재건, 경제 회복, 기반시설, 행정(운 } \\
\text { 영)경비로 구분 }\end{array}$ & $\begin{array}{l}\text { - 기존 지원예산 집행을 위한 계획(Initial } \\
\text { Plan)에 수정(추가)된 예산을 합한 금액 } \\
\text { 까지 지원분야별로 표기 }\end{array}$ \\
\hline
\end{tabular}

〈표 2-9〉 CDBG-DR 지원 협약의 주요 내용 (HUD(중앙정부)-루이지애나주, 2017)

\begin{tabular}{|c|c|c|}
\hline 구분 & 내용 & 비고 \\
\hline (1) 근거 & - 지원 근거 법률과 보조사업번호 적시 & - Public Law 114-223 / 114-254 \\
\hline (2) 기간 & - 보조금에 의한 사업 기간 & - 6년 이내 \\
\hline (3) 준수사항 & $\begin{array}{l}\text { - 관련 법 및 CDBG프로그램 규정 } \\
\text { - 지원받기 위해 지방정부가 제출한 사업계획, } \\
\text { 실행계획의 내용 } \\
\text { - CFR(Code of Federal Regulations)의 해 } \\
\text { 당 규정에 부합하는 정보의 제공 } \\
\text { - 수요 조사 및 환경 변화에 따른 실행계획 수 } \\
\text { 정 } \\
\text { - 보조금과 관련된 사기, 뇌물, 공과금 위반 행 } \\
\text { 위 등에 대하여 반드시 보고 } \\
\text { - 예산(보조금)과 관련있는 모든 기관, 단체, } \\
\text { 개인의 동 사업과 관련한 모든 행위와 관련 } \\
\text { 한 기준 마련, 유지 }\end{array}$ & $\begin{array}{l}\text { - 중앙정부가 추가적인 요청을 할 경우 따 } \\
\text { 라야 함 } \\
\text { - 지방정부에서 제출한 내용에 대한 확약의 } \\
\text { 개념으로 접근 가능 } \\
\text { - 중앙정부의 모니터링 및 감사에 대한 의 } \\
\text { 무 } \\
\text { - 연방관보에 게재된 공고문 근거 } \\
\text { - 보조금의 부정 사용 방지 } \\
\text { - 보조금과 관련한 행위에 대하여 사전에 } \\
\text { 문서화된 기준을 수립하여 준용 }\end{array}$ \\
\hline (4) 배정 예산 & $\begin{array}{l}\text { - 예산 총액 } \\
\text { - 분야별 예산 } \\
\text { - 사용 가능한 행정경비 예산 } \\
\text { - 사용 가능한 계획수립 경비 예산 }\end{array}$ & $\begin{array}{l}\text { - 통보문 본문에 적시된 최소 } 80 \% \text { 사용 의 } \\
\text { 무 분야 명시 } \\
\text { - 계획 수립과 행정경비 예산의 경우 최대 } \\
\text { 사용 가능한 금액을 배정하여 일정 금액 } \\
\text { 이상 사용하지 못하도록 함 }\end{array}$ \\
\hline (5) 부록 & \begin{tabular}{|l|} 
- 사업결과 보고와 관련된 내용 \\
- 보고 절차, 주기와 관련 법을 간략하게 안내
\end{tabular} & $\begin{array}{l}\text { - } \$ 10,000,000 \text { 이상의 보조금을 받은 경 } \\
\text { 우 중앙정부에 보고하도록 규정 }\end{array}$ \\
\hline
\end{tabular}

11) 상당 예산을 특정지역 투입에 할당하는 의무는 예산이 의회에서 통과된 후 게재하는 연방관보(Federal Register Notice)에 이미 포함되었음을 통보문에도 적시하고 있음 


\section{4. 성과협약형 포괄보조 방식의 쟁점}

\section{가. 포괄보조 방식의 순기능}

전통적인 국고보조 방식인 개별보조는 재정 특성 상 비효율성과 책임성 측면에 쟁점 이 있다. 첫째, 중앙정부의 표준적인 사업설계는 불가피하게 지방의 다양성을 충분히 수 용하기 힘들다. 문화예술분야와 같이 지역다양성이 상당한 재정사업에서는 표준화에 따 른 재정비효율성 쟁점은 상대적으로 더 크다. 둘째, 지역맞춤형을 지향하는 국고보조사 업에서는 정보격차와 도덕적 해이의 쟁점이 상당하다. 중앙정부는 지역다양성에 대한 정 보를 충분히 확보하지 못하고 한편으로 지방자치단체는 중앙정부의 관리 감독을 회피하 려는 다양한 형태의 도덕적 해이 전략을 모색하는 것이다. 셋째, 중앙정부의 예산재원 교부절차와 지방자치단체 현장에서 국고보조사업 집행과정의 불일치에 따른 예산재원 배분에서 비효율성이다. 지방재정사업이 당초 계획한 일정대로 진행되지 못하면 해당 사 업비는 차기연도로 이월되고(국비 뿐 아니라 지방비도 포함) 재원교부와 사업일정의 불 일치에 따라 사장되는 불용액 규모가 매년 상당한 수준이다.

포괄보조는 재정에 대한 책임을 강화하고 정책을 지역주도로 개편하는데 의의가 있 다. 포괄보조 사업으로 지방정부는 지역 실정에 맞는 계획을 수립하고 중장기적인 시각 에서 사업추진이 가능하며 예산사용 유연성을 높일 수 있게 된다. 중앙정부는 모든 지역 사회의 수요와 우선순위에 대한 파악이 어려울 수 있다. 그러나 지방정부는 중앙정부보 다 주민들과 더 가까워 서비스 수요와 욕구 파악이 용이하고 서비스 제공에 가장 효율적 인 수단을 찾기위해 노력할 수 있다. 포괄보조는 이러한 이점 때문에 낮은 비용으로 높 은 성과를 창출하는 재정효율화를 예상하는 것이고, 특히 지역 고유성과 다양성이 중요 한 가치인 문화서비스에 더 중요한 수단이라 할 수 있다. 지역은 유연한 예산 사용을 통해 용도가 정해진 범주형 보조금으로 불가능한 지역 상황에 적합한 사업과 새로운 시 도가 가능해지고 혁신을 기대할 수 있다.

더불어 정부 간 성과협약은 사전에 협력사항을 구체화하고 재정은 포괄적으로 지원하 여 지역 실정에 맞는 기획과 사업 추진이 가능하고, 사업기간에 대한 계약이 다년간 예 산을 보장하기 때문에 사업의 안정성과 실질적인 성과창출을 위한 노력을 기대할 수 있 다. 협약을 체결하는 과정에서 정책성과와 목표에 대해 점검하게 되고 사업수행은 정책 
효과 관점에서 추진하게 되어, 협약을 통한 관계는 포괄적인 재정지원에 대한 책임을 명확히 하고 정책을 지역 주도로 개편하는데 의의가 있다. 사무이양, 재정분권 등 지방 분권 과정에서 국가와 지방자치단체 간 관계설정이 모호하여 다양한 갈등이 발생되는데, 국가와 지방자치단체 간 협약은 권한과 역할을 사전에 조정함으로써 분쟁을 예방하고 성과를 구체화할 수 있다. 미회계감사원(GAO)은 포괄보조 사업으로 지방정부의 예산 사용 유연성을 높이고 연방정부의 보조금 관리를 단순화할 수 있으며 보조금 수령자 간 의 조정을 촉진함으로써 연방 지원 프로그램의 효과와 성과를 개선할 수 있는 잠재력을 가지고 있다고 보았다. 중앙정부(연방정부)의 개별사업의 성과목표에 대한 명확한 표준 과 책임을 유지하면서 여러 개별 보조사업을 통합하는 성과 파트너십(performance partnership) 구조를 기대하는 것이다.

\section{나. 포괄보조 방식의 한계}

개별 사업단위로 수직계열로 관리되는 보조사업 운영의 비효율성과 경직성 쟁점에 대 한 대안으로 포괄보조 전환이 있다. 그러나 포괄보조의 당초 의도에 의한 유연한 사업 추진, 지방정부의 중장기적인 계획 수립 및 시행, 중복 가능성을 제거하는 재정적 순기 능의 역할 등이 부각되지만, 정치적 고려에 의한 부적절한 사용, 책임의 부재 등이 지적 될 수 있다. 포괄보조프로그램을 활발하게 운용하는 미국의 시례에서는 재정효율성과 성 과책임 관점에서 몇 가지 한계들도 확인됐다.

첫째, 지방정부의 지출재량을 보장해도 포괄 '보조'이기 때문에 연방정부의 개입이 계 속 강화되는 경향이 있다. 프로그램 초기에는 지방정부의 재량을 보장해도 연방의회에서 관련 사업에 대한 관심이 높아지면, 재정 정치과정에서 불가피하게 중앙정부의 개입이 강화된다. 특정 목적에 사용되어야 하는 예산의 최소 비율을 별도로 설정하거나 다른 목적을 위해 사용할 수 있는 예산의 최대 비율을 설정하는 등의 제약조건 신설을 통해 지방정부 예산 집행의 유연성을 제약하기도 한다. 이는 지방정부가 연방정부의 정책목표 를 적절하게 충족시키지 못한다는 의회의 우려에 의해 포함되는 것이다.

둘째, 보조사업에 잠재된 정보격차와 도덕적 해이에 따른 비효율과 무책임의 쟁점은 (강도는 다양하지만) 여전히 계속 지속되는 경향이 있다. 지방정부 입장에서는 재원의 원천이 전국적으로 동원되는 연방재정 세입이기 때문에 지역사회와 주민들의 정치적 통 
제로부터 상대적으로 자유롭기 때문이다. 따라서 협약제(계약제)와 같은 제한을 부과하 여 프로그램에 대한 우선순위 선정능력 혹은 예산의 목적과 배치되는 사용에 대한 규제 를 할 수 있어야 한다(이재원 외, 2007).

셋째, 연방정부의 성과관리체계와 주 및 지방정부의 성과관리체계를 유기적으로 연계 하는 것이 현실적으로 쉽지 않고, 지방정부는 형식적으로 연방정부의 재정계획에 순응하 는 수준인 경우가 적지 않았다. 한국의 포괄보조로서 균특회계는 지방자치단체 정책집행 의 포괄성 및 재원배분의 재량과 자율성을 보장하고자 설계된 회계이나, 포괄보조 사업 의 지향점 및 전략목표 불명확성, 지방자치단체 기존 사업에 대한 재정보충 경향, 다중 평가로 인한 업무부담 및 행정비용 증가 등의 이유로 실질적인 지역문화 역량 강화에는 미흡한 평가(김성주 외, 2018; 이재원, 2016)도 있다.

넷째, 연방정부와 주정부의 관계에서는 포괄보조프로그램의 목적이 실현되어도 주정 부와 지방정부간 관계에서는 기존의 범주형 보조 방식이 적용되는 경우가 많았다. 이러 한 경우 보조사업에서 잠재된 비효율성 쟁점들이 그대로 발생하게 된다. 주정부가 중간 관리자로서 책임성이 높지 않을 경우에는 연방정부 수준에서 포괄보조프로그램은 특별 한 재정적인 의미를 가지기 힘들게 된다. 한국의 경우에도 포괄보조금 사업의 편성구조 와 국가균형발전 부문발전계획, 시·도 발전계획 간의 연계성 부족, 포괄보조금이 지방자 치단체 전체 예산 대비 낮은 비중 등으로 인한 지방자치단체의 능동적이고 적극적인 참 여 유인 미흡 등의 문제점이 지적되고 있다(정종석 외, 2015).

이러한 포괄보조 방식의 한계를 보완하기 위해서는 국가의 정책적 지향점과 목표를 공유하는 시스템 구축이 중요하다. 중앙정부와 지방자치단체 간의 권한과 역할, 이익, 책임 등을 분명히하고 협력사항을 사전에 구체화하는 '협약방식을 강조하는 것이다. 다 만 협약을 체결하는 과정에서 정책성과와 목표에 대한 점검, 사업 추진과정에서 정책효 과 관점 반영 등 행정관리 및 평가기법에 대한 개발과 노력이 동반되어야 할 것이다.

〈표 2-10〉 포괄보조방식의 순기능과 한계

\begin{tabular}{c|c}
\hline 포괄보조방식 순기능 & 포괄보조방식 한계 \\
\hline & - 지방정부의 지출재량을 보장해도 포괄 “보조'이기 때 \\
- 지역 실정에 맞는 계획을 수립하고 중장기적인 시각 & 문에 중앙정부의 개입이 계속 강화되는 경향 \\
에서 사업추진이 가능, 예산사용 유연성 확보 & - 보조사업에 잠재된 정보격차와 도덕적 해이에 따른 \\
- 다년간 예산을 보장하기 때문에 사업의 안정성과 실 & 비효율과 무책임 지속 \\
질적인 성과창출을 위한 노력을 기대 & - 중앙정부와 지자체의 성과관리체계 연계가 현실적으 \\
& 로 어렵고, 중앙정부 계획에 형식적으로 순응 \\
\hline
\end{tabular}




\section{제2절 지역문화정책에서 성과협약형 포괄보조 필요성}

\section{1. 지역문화정책과 문화분권}

\section{가. 지역문화진흥 정책의 변화}

2014년 「지역문화진흥법」12) 제정 이후 지역문화 및 생활문화에 대한 관심은 더욱 확대되었으며, 문화격차 해소와 지역의 문화역량 강화를 중심으로 지역문화정책이 강조 되고 있다.

국가 정책에서에서 지역문화진흥이 등장하기 시작한 시기는 80년대「제5차 경제사회 발전-문화부문 계획」에서 지방문화 육성을 명시하면서 시작되었고, 지역문화 활성화 측 면에서의 정책을 지속 반영해왔다. 문화정책에서 지역이 중요해진 시기는 지방자치제 시 행과 궤를 같이하며, 특히 90년대 중반 도시개발 및 도시재생에 있어 문화의 역할과 중 요성이 커지면서 지역문화정책이 강조되는 기점이 되었다. 2000년 초반까지 지역의 문 화기반시설을 정비하고 공간운영에 중점을 두었다가 점차 지역문화전문인력양성, 지역 특화문화예술사업, 문화도시 등 다양한 지역문화 활성화사업을 중요한 정책과제로 다루 고 있다.

재정관계도 분권화 방향으로 변화되는데 90년대의 지역문화진흥정책은 국가가 직접 지 역의 축제, 조형물 하나 설치까지 건건히 국고보조사업으로 관리하는 방식이었다. 2000 년대 중반부터 본격 분권과 균형발전을 강조하고 국고보조금 정비 경험을 통해 지역문화 사업에 대한 중앙정부 직접추진에 대한 문제를 인식하면서 지방자치단체 자생력을 중시, 이후 문화자치 실현과 정부 간 협력관계로 실질적 자치분권을 강조하고 있다. 다년지원, 통합공모사업 등 사업운영 자율성 부여와 효율화를 위한 시도가 계속되고 있다.

12)「지역문화진흥법」에서 지역문화진흥의 기본원칙은(제 3 조), (1) 지역 간의 문화격차 해소와 지역문화 다양 성의 균형 있는 조화, (2) 지역주민의 삶의 질 향상 추구, (3) 생활문화가 활성화될 수 있는 여건 조성, (4) 지역문화의 고유한 원형의 우선적 보존으로 명시하고 있다. 
〈표 2-11〉정부별 문화분권 특징

\begin{tabular}{|c|c|c|c|c|c|c|}
\hline \multicolumn{2}{|c|}{ 구분 } & $\begin{array}{c}\text { 김대중정부 } \\
\text { (1998 2002) }\end{array}$ & $\begin{array}{c}\text { 노무현정부 } \\
\text { (2003 2007) }\end{array}$ & $\begin{array}{c}\text { 이명박정부 } \\
\text { (2008 2012) }\end{array}$ & $\begin{array}{c}\text { 박근혜정부 } \\
\text { (2013 2017.3.) }\end{array}$ & $\begin{array}{c}\text { 문재인정부 } \\
\text { (2017.5 2022.5.) }\end{array}$ \\
\hline \multicolumn{2}{|c|}{$\begin{array}{l}\text { 지역문화 } \\
\text { 정책접근 }\end{array}$} & $\begin{array}{l}\text {-균형발전 } \\
\text {-사회통합 }\end{array}$ & $\begin{array}{l}\text {-균형발전 } \\
\text {-지역문화역량제고 }\end{array}$ & \begin{tabular}{|l|l|}
-지역협력 \\
-실용적 역할분담
\end{tabular} & $\begin{array}{l}\text { - 지역문화 자생력 } \\
\text { - 생활문화형 정책 }\end{array}$ & $\begin{array}{l}\text {-문화자치와 분권 } \\
\text {-포용/혁신 }\end{array}$ \\
\hline \multirow{4}{*}{ 정책 } & 문화 & \begin{tabular}{|l|}
-국민의 정부, 새문화 \\
정책
\end{tabular} & -창의한국 & $\begin{array}{l}\text {-문화비전 } \\
\text { 2008-2012 }\end{array}$ & -문화가 있는 삶 & $\begin{array}{l}\text {-문화비전2030, } \\
\text { 사람이 있는 문화 }\end{array}$ \\
\hline & $\begin{array}{l}\text { 지역 } \\
\text { 문화 }\end{array}$ & & -지역문화 활성화 대책 & & $\begin{array}{l}\text {-제1차지역문화진흥 } \\
\text { 기본계획 }\end{array}$ & $\begin{array}{l}\text {-제2차지역문화진흥 } \\
\text { 기본계획 }\end{array}$ \\
\hline & 법제 & & & & \begin{tabular}{|c}
-지역문화진흥법제정 \\
$(2014.07 .29)$.
\end{tabular} & \\
\hline & $\begin{array}{l}\text { 추진 } \\
\text { 기구 }\end{array}$ & $\begin{array}{l}\text {-문화관광부 예술국 } \\
\text { 전통지역문화과 }\end{array}$ & $\begin{array}{l}\text {-문화관광부 문화 } \\
\text { 정책국 지역문화과 }\end{array}$ & $\begin{array}{l}\text {-문화체육관광부 문화 } \\
\text { 정책국 지역문화팀 } \\
\text {-문화예술정책실 지역 } \\
\text { 문화과'009 ) } \\
\text {-문화예술정책실 지역 } \\
\text { 민족문화과('11 ) }\end{array}$ & $\begin{array}{l}\text {-문화체육관광부 문화 } \\
\text { 예술정책실 지역민족 } \\
\text { 문화과 } \\
\text {-문화예술정책실 문화 } \\
\text { 기반정책관 지역전통 } \\
\text { 문화과'(14 ) }\end{array}$ & $\begin{array}{l}\text { 문화체육관광부 문화 } \\
\text { 예술정책실 지역문화 } \\
\text { 정책관 }\end{array}$ \\
\hline \multicolumn{2}{|c|}{ 주요시책 } & $\begin{array}{l}\text {-2003년까지 지역문화 } \\
\text { 재정 } 5 \% \\
\text {-지역간 공동제작프로 } \\
\text { 그램 활성화 } \\
\text {-지역특성을 살린시범 } \\
\text { 문화의 거리조성 } \\
\text {-특화도서관 건립 } \\
\text {-시·군·구 문화원 확대 }\end{array}$ & $\begin{array}{l}\text { (창의한국 中) } \\
\text {-지역의 문화역량 제고 } \\
\text {-쾌적하고 아름다운 } \\
\text { 공간환경 조성 } \\
\text {-문화시설의 균형적 } \\
\text { 환충과 운영황성화 } \\
\text {-문화정보체계 구축 } \\
\text {-지역문화의 역동적 } \\
\text { 특성화 } \\
\text {-농어촌의 문화환경 } \\
\text { 조성 } \\
\text {-신행정수도 문화기획 } \\
\text { (지역문화활성화대책) } \\
\text {-문화기반시설의 운영 } \\
\text { 활성화 } \\
\text {-문화예술교육 확대 } \\
\text {-민.관·한 연계를 통한 } \\
\text { 지역문화 발전체계 } \\
\text { 정립 } \\
\text {-지방문화원 육성 } \\
\text {-생황친화적 문화공간 } \\
\text { 조성 운영 } \\
\text {-문화놘광을 통한 기초 } \\
\text { 단위 마을 살리기 운동 }\end{array}$ & $\begin{array}{l}\text {-지역문화공간 확충, } \\
\text { 서비스 확대 } \\
\text {-지방문화원 거ㅈㅓㅓㅎㅘ } \\
\text {-생환공감형 문화정책 } \\
\text {-지역문화 전문인력 } \\
\text { 양성사업 } \\
\text {-지역순회공연지원 } \\
\text { (방방곡곡) } \\
\text {-지역 생활문화축제 등 } \\
\text { 다문화체험 프로그램 } \\
\text {-순수예술지원방식개선 } \\
\text { 및 지역협력확내 } \\
\text { (4대방향) } \\
\text {-지역근대상업유산 } \\
\text { 활용 문화공간 및 } \\
\text { 문화도시 조성 } \\
\text {-지역기반의콘텐츠 } \\
\text { 기업창업환성화 } \\
\text {-지역관광산업 지원 } \\
\text { 체계 구축 } \\
\text {-지역 특화 관광자원 } \\
\text { 개발 } \\
\text {-지역 스포츠클럽 정착 } \\
\text { 및 활성화 }\end{array}$ & $\begin{array}{l}\text { (문화가 있는 삶 中) } \\
\text {-문지역학 활성화 및 } \\
\text { 지역문화지표 개발 } \\
\text {-지역문화재대난의 법적 } \\
\text { 근거 마련 } \\
\text {-지역문화기관간 '지역 } \\
\text { 문화협의체" 구성 } \\
\text {-컨설팅 지원 } \\
\text {-지역협렿형 지역문예 } \\
\text { 기금 확대 } \\
\text {-지역사업 평가 강화 } \\
\text {-지역문화 매개인력 } \\
\text { 처우개선 } \\
\text {-'문화여가사' 자격증 } \\
\text { 도입 } \\
\text { (지역문화진흥기본계획) } \\
\text {-문화가 있는 삶 } \\
\text {-지역에서 꽃피는문화 } \\
\text {-세계와 소통하는문화 } \\
\text {-남북의 통로가 되는 } \\
\text { 문화 } \\
\text {-문화진흥기반구축 }\end{array}$ & $\begin{array}{l}\text { (문화비전2030 中) } \\
\text {-지역 문화의 고유성 } \\
\text { 유지 및 발전 } \\
\text {-지역 내 문화자치 } \\
\text { 역량을 위한 기반 } \\
\text { 조성 } \\
\text {-지역주민 참여 활성화 } \\
\text { 를 위한 체계 마련 및 } \\
\text { 계기이 제공 } \\
\text {-중앙과 지방 간 협치 } \\
\text { 모델 설계 } \\
\text { (지역문화진흥기본계획) } \\
\text {-시민의 참여로 문화 } \\
\text { 자치 생태계 구축 } \\
\text {-포용과 소통으로 생활 } \\
\text { 기반 문화환경 조성 } \\
\text {-지역의 개성있는 문화 } \\
\text { 발굴:활용 } \\
\text {-문화적 가치로 지역의 } \\
\text { 혁신과 발전 }\end{array}$ \\
\hline \multicolumn{2}{|c|}{$\begin{array}{l}\text { 문화분권 } \\
\text { 평가 }\end{array}$} & \begin{tabular}{|l|} 
지역문화사업 본격 \\
추진, 중앙정ㅂ 소규모 \\
일회성 사업 중심
\end{tabular} & $\begin{array}{l}\text { 국가 직접 사업 기획 } \\
\text { 방식에서 지역문화기반 } \\
\text { 마련 중요성 인지 }\end{array}$ & $\begin{array}{l}\text { 지역문화를 육성하고 } \\
\text { 협력하는 대상으로 접 } \\
\text { 근, 지역 자생력 중시 }\end{array}$ & $\begin{array}{l}\text { 지역자율과 상생발전을 } \\
\text { 표방, 이전 정부정책 } \\
\text { 지속 }\end{array}$ & $\begin{array}{l}\text { 문화자치 실현 강조, } \\
\text { 정부 간 관계와 행정 } \\
\text { 체계 중시 }\end{array}$ \\
\hline
\end{tabular}

자료: 정보람(2020),지방분권에 따른 문화재정 현황과 정부간 역할분담 방안, 한국문화관광연구원. 


\section{나. 포괄화·상향식 접근방식 확산}

지역문화를 포함한 문화정책은 재정의 형태가 '소액다건' 으로 인해 여러 가지 한계에 봉착해왔는데, 오랜기간 국고보조사업의 개선 논의에도 불구하고 제도적 문제가 눈에띄 게 변화되지 못하다가 최근 몇 년 사이 의미있는 시도가 이루어지고 있다. 이는 재정의 포괄화와 계획의 상향식 접근방식에 대한 노력이다.

문화사업은 성과를 계량적으로 측정하기 어려운 특성을 가지고 있고 정책목표와 인과 성을 입증하기 어렵다보니, 계획에 대한 검토에는 세세한 단위로 통제적 관점이 적용되 고 그 결과에 대한 판단은 실적 중심으로 적용되는 경향이 있다. 이렇다보니 계획단계에 서의 새로운 시도, 창의적인 도적은 어렵고 전례가 있고 비교군이 있거나 단가를 셀 수 있는 소규모 단위로 통제되어 왔다. 그러나 소액다건의 실적위주 재정사업에 대한 비효 율성 쟁점이 부각되면서 포괄보조, 상향식 접근, 계획의 연계 등이 시도되었다.

2005년 국고보조사업 개편 및 지방이양으로 국고보조사업 수를 줄이고자 노력하였고 2010년 이후부터는 유사사업의 통폐합 방식으로 접근하다가, 2015년 들어 계획에 대한 포괄보조 방식 논의가 적극 등장하였다. 소액다건형 사업은 단순히 사업단위가 작아서 합하는 문제가 아닌 중앙부처와 지방자치단체가 문화사업의 성과를 바라보는 관점이 바 뀌어야 한다는 점에 공감하고 이를 개선하기 위해 개별사업의 통합성, 패키지화가 필요 하다고 보는 것이다.

최근에는 지역 수준에서 개별 정책 사업들의 통합성을 높이기 위해 개별공모 사업을 '통합지원'하는 방식을 시도하고 있다. 2020년 개별 단위 문화사업과 지역자원(시설, 프 로그램, 주민, 매개자 등)의 연계 계획에 대해 통합적으로 지원하는 '지역문화 생태계 구축 통합운영’이 시범 추진되었다. 지역별 수요자 중심의 자생적 생태계 구축을 위해 시설·공간·주민, 교육·양성·활동과 관련된 기존의 6개 사업(13억 96백만원 규모)을 통 합(패키지) 지원하는 것이다. 시범사업에서 권역별 설명회와 선정심사를 거쳐 최종적으 로 5 개 지역(기초자치단체)을 선정하여 1 개 지역 당 202백만원을 지원하였다. 지역문화 생태계 구축 통합운영 사업은 지역 내 여건과 수요에 맞춰 시설, 프로그램, 주민, 매개인 력 등을 연계하여 종합적인 시각의 계획을 수립하게 하는데 의의가 있다. 그러나 외형적 으로는 개별사업의 연계·통합적 접근과 포괄보조 시스템을 표방하지만, 기존의 개별사 업 지침에 의해 사업이 운영되도록 되어있어, 개별사업과 크게 다를바 없는 방식의 한계 
가 있다. 중앙정부인 문화체육관광부 측면에서는 문화정책과, 지역문화정책과, 문화예술 교육과 등 여러 개별부서에서 추진하고 있고, 이전의 개별사업 운영지침과 회계를 그대 로 유지하고 있어 실질적인 변화를 기대하기 어려운 것이다.

[그림 2-2] 지역문화 생태계 구축 통합운영 시범사업 추진체계

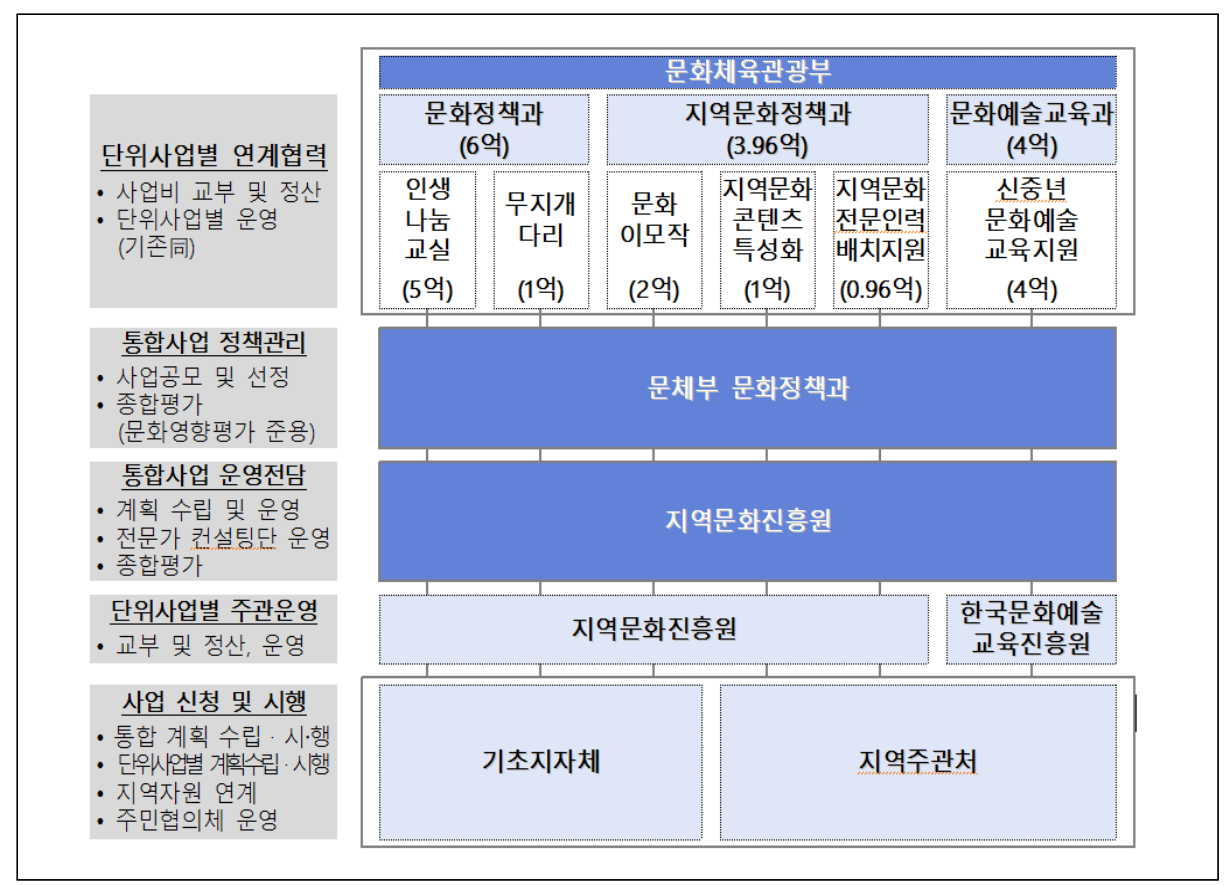

더불어 지역 중심의 생활문화 활성화를 마련하고자 그동안 개별단위로 지원했던 생활 문화 공동체 만들기, 생활문화동호회 활성화, 생활문화센터 활성화 등 3개 사업을 통합 하여 지원하는 ‘생활문화사업 통합지원’이 추진되었다. 2021년 문화체육관광부는 기초 지방자치단체 8 개 지역에 총 1,382 백만원(지역별 173 백만원 내외)을 지원할 계획이다. 지역 주관단체는 지역주민, 생활문화동호회, 생활문화 시설, 생활문화센터 등 지역사회 를 구성하는 다양한 주체들이 지역 고유의 생활문화 환경을 함께 만들어갈 수 있도록 건강한 관계망을 형성하고 사업 추진을 위한 협력체계를 마련해야 한다. 생활문화사업 통합지원 역시 지역 내 협력과 사업 간 연계를 유도하는 측면에서 의미있는 변화를 기대 할 수 있지만, 각각의 개별사업 내용을 지방자치단체가 설계하거나 기획할 재량은 주어 지지 않아 포괄보조 방식보다는 제한된 재량을 갖는다. 
〈표 2-12〉 생활문화사업 통합지원 내용

\begin{tabular}{|c|c|}
\hline 지원사업 & 지원규모 및 내용 \\
\hline $\begin{array}{c}\text { 생활문화공동체 } \\
\text { 만들기 지원 }\end{array}$ & $\begin{array}{l}\text { - 지원내용: 일상적 삶의 관계를 변화시키는 생활문화공동체 활동 지원 } \\
\text { - 지원규모: 지역당 생활권 공동체 } 3 \text { 개 내외, } 60 \text { 백만원 내외/1개 공동체당 평균 } 20 \text { 백만원 } \\
\text { - 지원대상: 마을 주민조직 및 문화예술 단체기관시설 }\end{array}$ \\
\hline $\begin{array}{c}\text { 생활문화동호회 } \\
\text { 활성화 지원 }\end{array}$ & $\begin{array}{l}\text { - 지원내용: 생환문화동호회 활동/교류 지원, 생활문화 창의 프로그램 활동 지원(지역 } \\
\text { 생활문화 환경과 여건에 따른 활동 지원) } \\
\text { - 지원규모: 지역당 4개 단체 이상, } 45 \text { 백만원 이내 / 1개 단체 당 평균 } 11 \text { 백만원 } \\
\text { - 지원대상: 생활문화시설, 생활문화동호회 연합회, 공공/민간단체 }\end{array}$ \\
\hline $\begin{array}{l}\text { 생활문화센터 } \\
\text { 활성화 지원 }\end{array}$ & $\begin{array}{l}\text { - 지원내용: 생활문화센터 거점 플랫폼 형성을 위한 운영 지원(지역 생활문화 협력체계 } \\
\text { 구성 및 교류/지역 생활문화시설 간 연계 및 교류 등) } \\
\text { - 지원규모: 지역당 } 2 \text { 개 센터 이내, } 40 \text { 백만원 이내 / 1개 센터당 최대 20백만원 } \\
\text { - 지원대상: } 2020 \text { 년 } 12 \text { 월 기준 개관운영 중인 생활문화센터(붙임2 참조) } \\
\text { ※ 단, 기초자치지역에 생활문화센터가 없는 경우에는 생활문화센터 활성화 지원 사 } \\
\quad \text { 업을 제외하고 신청 가능 }\end{array}$ \\
\hline $\begin{array}{l}\text { 통합사업 } \\
\text { 운영 관리 }\end{array}$ & $\begin{array}{l}\text { - 지원내용: 통합사업 운영관리(단기근로자 활용비 및 사업 운영 관리비) } \\
\text { · 통합 사업 추진협의체 구성운영(단위사업별 추진주체) } \\
\text { · 사업 추진협의체 협력 연수회(워크숍) 및 네트워크 프로그램 } \\
\text { · 사업신청-정산, 추진주체 행정지원 등 } \\
\text { - 지원규모: 사업비 총액의 } 20 \% \text { 이내, 최대 28백만원 이내 }\end{array}$ \\
\hline
\end{tabular}

자료: 지역문화진흥원(2021), 2021 생활문화사업 통합지원공모

주목할만한 점은 지역 주도의 사업발굴을 기초로 지방자치단체 계획에 대해 포괄적 규모의 예산을 지원하는 사업방식의 등장과 확대이다. 문화체육관광부의 문화도시, 계획 공모형 지역관광개발사업, 관광거점도시가 대표적인 사례이다. 이들 사업은 중앙정부가 구체적인 사업내용을 기획하여 공모하는 방식과 달리 중앙정부가 포괄적인 사업유형을 제공하면 지방자치단체가 지역 특성 및 수요에 맞는 계획(제안서)을 제출하여 승인된 지 방자치단체에 다년간 예산을 지원하는 방식이다.

2019년 12월 처음으로 지정된 문화도시는 지역별로 특색있는 문화자원을 활용하여 지역의 문화브랜드를 담은 ‘문화도시 조성계획’에 대해 중앙정부가 검토하고, 승인된 지 자자체에 5 년간 최대 국비 100 억원을 지원하는 사업이다. 이전에도 문화특화지역조성, 지역거점문화도시 조성, 문화적 도시재생 등의 지역기반 문화사업이 존재하였지만 보다 강력한 상향식 접근방법과 중기시각의 계획과 재정재량을 부여하고 있다. 계획공모형 지 역관광개발사업과 관광거점도시 역시 지방자치단체가 작성한 지역 특성 및 수요에 맞는 관광개발 계획에 대해 중앙정부가 검토하고 승인된 지방자치단체에 5년간 국비를 지원 한다. 지역 간 연계를 고려하여 종합적 개발방식(콘텐츠개발, 역량강화, 관리운영 등)으 로 전환한 모델이다. 


\section{다. 최근 문화분권 추진내용}

2017년 문화체육관광부가 지역·계층 간 문화 격차 문제에 대응하고자 문화예술정책 실 산하의 문화기반정책관을 지역문화정책관으로 재편하고, 생활문화와 지역문화의 “균 형 발전”을 위한 정책을 보다 더 조직적으로 추진하기 시작하였다. 현재 지역문화정책관 은 문화·창조도시 조성 및 진흥, 박물관·미술관·문화원 등 문화기반시설에 관한 종합계 획 수립, 도서관정보정책 발전에 관한 종합계획 수립 등 지역의 문화적 역량강화와 인프 라구축 지원을 추진하고 있다.

문화정책 비전인 2018년 5월에 발표된 「문화비전2030, 사람이 있는 문화」에서는 각 지역의 문화적 분권과 고유성을 살릴 수 있는 분권형 문화정책의 이행을 방향으로 설정 하고 있다. 그리고 9대 의제 중 6번에서 문화정책을 '중앙집권적 문화’에서 '문화자치와 분권'으로 전환하고 공동체의 다양성을 위해 '지역문화 분권 실현'을 설정했다.

지역문화분권 실현을 위해서 다음과 같은 네 개의 과제가 제시되었다. (1) 지역 문화의 고유성 유지 및 발전, (2) 지역 내 문화자치 역량을 위한 기반 조성, (3) 지역주민 참여 활성화를 위한 체계 마련 및 계기 제공, (4) 중앙과 지방 간 협치모델 설계 등이다.

동 계획에서, 문화분권은 지역의 문화격차를 해소하고 고유한 문화 양식을 보호·확산 하며, 지역 시민들의 문화향수와 문화 참여 권리를 보장하는 핵심 문화정책으로 인식했 다(새문화정책준비단, 2018)이다. 이와 관련하여 중앙정부와 지방자치단체는 문화예술 정책에서 담당 역할과 기능을 나누고 보다 효율적으로 사업을 수행하기 위한 권력, 권한, 자원운영체계의 분권화가 필요하다.

문화분권을 위한 여섯 가지 대표과제 가운데 첫 번째 과제는 '지역문화자치를 위한 기반조성'이며, 핵심 추진과제로서 '포괄적 보조사업 확대와 성과평가 및 환류체계 시스 템 구축'이 제시됐다. 이러한 비전 내용을 실천하기 위해 개별 재정사업단위로 운영되는 문화보조금제도들을 프로그램이나 중범위 사업단위에서 중앙-지방간 성과협약방식을 적용하는 포괄보조 프로그램으로 전환할 필요가 있다. 


\section{2. 정부 간 재정관계}

\section{가. 중앙-지자체 간 재정관계 특징}

중앙정부와 지방자치단체 간 재정관계는 재원조달 능력과 사무부담 수준에 차이가 있 어 대체로 중앙정부에 의존하는 구조이고, 재정이전 시스템은 크게 지방교부세제도와 국 고보조금제도로 구분된다.

2021년 지방세 비율은 24.7\%(국세 75.3\%)인데, 예산서 상 편성액(통합재정 지출액) 은 지방자치단체 $35.0 \%$ (중앙정부 55.5.\%), 이전재원을 공제한 실제 사용액은 지방자치 단체 44.0\%(중앙정부 42.8\%)이다. 즉 우리나라 조세할당 구조가 세입은 중앙정부에 집 중되지만 실제 집행은 지방자치단체가 더욱 크기 때문에 구조적으로 항상 지방자치단체 의 예산이 부족하게 되어있고 부족한 예산은 국고보조금, 교부세와 같은 이전재원으로 충 당해야 한다.

〈표 2-13〉국세 대 지방세 비율

(단위: 억원, \%

\begin{tabular}{c|c|c|c|c|c|c}
\hline 구분 & 2016 & 2017 & 2018 & 2019 & 2020 & 2021 \\
\hline \multirow{2}{*}{ 국세 } & $2,425,617$ & $2,653,849$ & $2,935,704$ & $2,934,543$ & $2,797,123$ & $2,827,425$ \\
& $(76.3)$ & $(76.7)$ & $(77.7)$ & $(76.4)$ & $(75.2)$ & $(75.3)$ \\
\hline \multirow{2}{*}{ 지방세 } & 755,306 & 804,063 & 843,153 & 904,572 & 921,924 & 926,047 \\
& $(23.7)$ & $(23.3)$ & $(22.3)$ & $(23.6)$ & $(24.8)$ & $(24.7)$ \\
\hline
\end{tabular}

주 1) 2018년까지는 결산, 2020년은 최종예산, 2021년은 당초예산

2) 괄호( )는 구성비

가료: 행정안전부(2021), 2021년 지방자치단체 통합재정개요(상)

[그림 2-3] 국가와 지방자치단체 재정사용액 비교(순계기준)

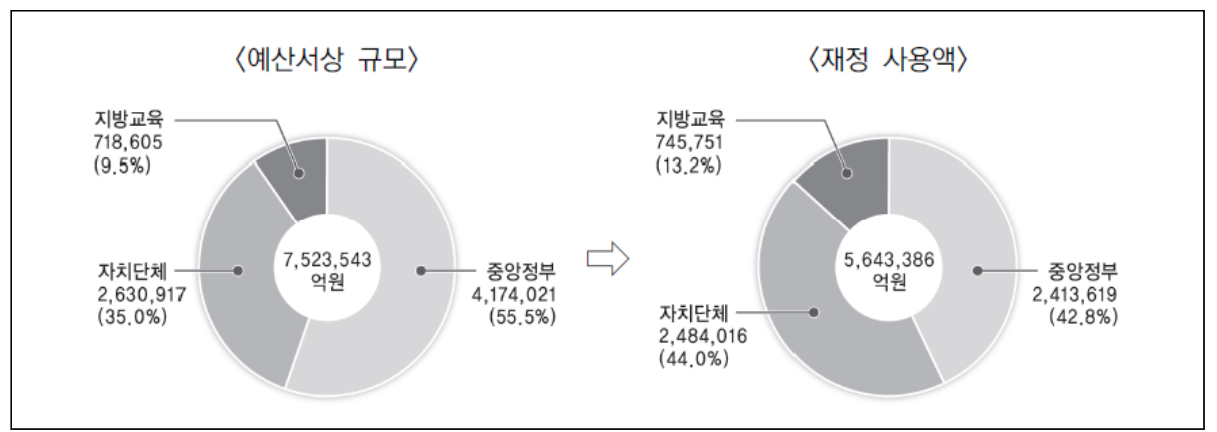

자료: 행정안전부(2021), 2021년 지방자치단체 통합재정개요(상) 
재정자립도는 지방자치단체의 재정수입 자체 충당능력을 나타내는 세입분석지표로서 일반회계 세입 중 지방세와 세외수입의 비율로 측정한다. 이 비율이 100에 가까울수록 해당 자치단체의 세입징수기반이 좋은 것을 의미하는데 2021년 평균 $48.7 \%$ 로 지난 5 년 이상 하락 추세이다.

〈표 2-14〉지방자치단체 재정자립도

\begin{tabular}{c|c|c|c|c|c|c}
\multicolumn{1}{|c}{ (단위: \%) } \\
\hline 구분 & 2016 & 2017 & 2018 & 2019 & 2020 & 2021 \\
\hline 전국평균 & 52.5 & 53.7 & 53.4 & 51.4 & 50.4 & 48.7 \\
\hline 특·광역시 & 66.6 & 67.0 & 65.7 & 62.7 & 60.9 & 58.9 \\
\hline 도 & 35.9 & 38.3 & 39.0 & 36.9 & 39.4 & 36.5 \\
\hdashline 시 & 37.4 & 39.2 & 37.9 & 36.8 & 33.5 & 32.3 \\
\hdashline 군 & 18.0 & 18.8 & 18.5 & 18.3 & 17.3 & 17.3 \\
\hline 자치구 & 29.7 & 30.8 & 30.3 & 29.8 & 29.0 & 28.5 \\
\hline
\end{tabular}

주 1) 당초예산, 일반회계 기준

2) 전국평균 순계, 이외는 총계 기준

자료: 행정안전부(2021), 2021년 지방자치단체 통합재정개요(상)

재정자주도는 일반회계 예산 중 자체수입(지방세+세외수입)과 자주재원(지방교부세+ 재정보전금+조정교부금)을 포함한 일반재원의 비율로서 전체 세입에서 사용처를 자율적 으로 정하고 집행할 수 있는 재량을 나타내는 세입분석 지표이다. 이 비율은 100 에 가까 울수록 해당 자치단체의 실질적인 재정운용 자율성이 좋은 것을 의미하는데 2021년 평 균 70.8\%로 지난 5년 이상 하락 추세이다.

〈표 2-15〉지방자치단체 재정자주도

\begin{tabular}{c|c|c|c|c|c|c}
\multicolumn{1}{|c}{ (단위: \%) } \\
\hline 구분 & 2016 & 2017 & 2018 & 2019 & 2020 & 2021 \\
\hline 전국평균 & 74.2 & 74.9 & 75.3 & 74.2 & 73.9 & 70.8 \\
\hline 특·광역시 & 74.4 & 74.6 & 73.4 & 71.8 & 69.8 & 67.4 \\
\hline 도 & 47.3 & 49.1 & 50.2 & 48.9 & 50.6 & 46.5 \\
\hline 시 & 65.9 & 67.2 & 66.4 & 64.8 & 63.8 & 60.9 \\
\hline 군 & 62.9 & 64.1 & 65.2 & 65.3 & 64.9 & 61.2 \\
\hline 자치구 & 47.0 & 48.1 & 47.5 & 46.1 & 45.5 & 44.8 \\
\hline
\end{tabular}

주 1) 당초예산, 일반회계 기준

2) 전국평균 순계, 이외는 총계 기준

자료: 행정안전부(2021), 2021년 지방자치단체 통합재정개요(상) 


\section{나. 문체부-지자체 국고보조금 특징}

\section{1) 소액다건형 국고보조사업 형태}

문화체육관광부의 지방자치단체 국고보조금과 관련하여 주목할 점은 지방자치단체 국고보조 비율이 높고 소액다건형이라는 점이다. 국고보조금은 특정 부처에 편중되어 있 는데, 상위 5 개 부처(문체부, 농식품부, 복지부, 환경부, 여가부)가 전체 국고보조금의 $78 \%(58$ 조 4,442 억원) 수준을 차지하고 있다. 이 중 문화체육관광부는 $23.3 \%(1$ 조 5,976 억원)를 지방자치단체에 국고보조금으로 이전하고 있어 총지출 대비 국고보조금 비율이 5번째로 높은 부처이다.

〈표 2-16〉 부처별 지방자치단체 국고보조금 현황(2021년)

\begin{tabular}{|c|c|c|c|c|c|c|c|c|}
\hline & \multirow[b]{2}{*}{ 부처별 } & \multirow[b]{2}{*}{ 총 지출 } & \multirow[b]{2}{*}{$\begin{array}{c}\text { 지자체 국고 } \\
\text { 보조금 계 }\end{array}$} & \multicolumn{4}{|c|}{ 지자체 보조금 회계별 구성 } & \multirow{2}{*}{$\begin{array}{c}\text { 지자체 } \\
\text { 국고보조금 } \\
\text { 비중 }\end{array}$} \\
\hline & & & & 일반회계 & 균특회계 & 기타특별 & 기금 & \\
\hline \multirow{5}{*}{$\begin{array}{l}\text { 상위 } \\
5 \text { 개 } \\
\text { 부처 }\end{array}$} & 문체부 & 68,637 & 15,976 & 1,466 & 6,472 & 555 & 7,482 & 23.3 \\
\hline & 농식품부 & 162,856 & 50,358 & 72 & 7,792 & 13,171 & 29,324 & 30.9 \\
\hline & 복지부 & 895,766 & 443,647 & 427,227 & 3,365 & 546 & 12,509 & 49.5 \\
\hline & 환경부 & 111,715 & 64,873 & 179 & 6,170 & 51,341 & 7,183 & 58.1 \\
\hline & 여가부 & 12,001 & 9,588 & 3,444 & 452 & - & 5,692 & 79.9 \\
\hline \multicolumn{2}{|c|}{ 5개부처 소계 } & $1,250,975$ & 584,442 & 432,388 & 24,251 & 65,613 & 62,190 & 46.7 \\
\hline \multicolumn{2}{|r|}{ 전 체 } & 557,9872 & 748,016 & 507,786 & 65,506 & 88,664 & 86,060 & 13.4 \\
\hline
\end{tabular}

주: 당초예산 순계, 총지출 기준,

자료: 행정안전부(2021), 2021년도 지방자치단체 통합재정 개요(상)

내역사업 개수를 살펴보면, 2021년 기준 문화체육관광부는 지방자치단체 국고보조 비중이 $20 \%$ 이상인 부처 중에서 1 건당 내역사업 국고보조금이 가장 작은 부처로, 지방자 치단체 국고보조금 내역사업은 276건이며 내역사업 1 건당 지방자치단체 국고보조금은 58 억원이다. 앞서 살펴본 지방자치단체 국고보조금 비중이 높은 5개부처의 내역사업 1 건당 지방자치단체 국고보조금은 농식품부 244 억원, 복지부 1,643 억원, 환경부 328 억 원, 여가부 155 억원이다. 
〈표 2-17〉 부처별 보조사업 편성(2021년)

(단위: 억원, \%, 건)

\begin{tabular}{|c|c|c|c|c|c|}
\hline 구분 & 총 지출 & $\begin{array}{c}\text { 지자체 } \\
\text { 국고보조금 }\end{array}$ & $\begin{array}{c}\text { 지자체 } \\
\text { 국고보조금 비중 }\end{array}$ & 내역사업수 & $\begin{array}{c}\text { 내역사업 1건당 } \\
\text { 국고보조금 }\end{array}$ \\
\hline 전 체 & 557,9872 & 748,016 & 13.4 & 1,970 & 380 \\
\hline 대법원 & 20,437 & 166 & 0.8 & 1 & 166 \\
\hline 기획재정부 & 328,435 & 3,219 & 1.0 & 9 & 358 \\
\hline 교육부 & 764,645 & 2,332 & 0.3 & 8 & 292 \\
\hline 과학기술정보통신부 & 176,260 & 284 & 0.2 & 16 & 18 \\
\hline 외교부 & 28,409 & 68 & 0.2 & 5 & 14 \\
\hline 통일부 & 14,749 & 141 & 1.0 & 5 & 28 \\
\hline 법무부 & 40,582 & 597 & 1.5 & 5 & 119 \\
\hline 국방부 & 377,282 & 0.45 & 0.0 & 1 & 0.45 \\
\hline 행정안전부 & 574,451 & 36,086 & 6.3 & 111 & 325 \\
\hline 문화체육관광부 & 68,637 & 15,976 & 23.3 & 276 & 58 \\
\hline 농림축산식품부 & 162,856 & 50,358 & 30.9 & 206 & 244 \\
\hline 산업통상자원부 & 111,860 & 9,393 & 8.4 & 69 & 136 \\
\hline 보건복지부 & 895,766 & 443,647 & 49.5 & 270 & 1,643 \\
\hline 환경부 & 111,715 & 64,873 & 58.1 & 198 & 328 \\
\hline 고용노동부 & 356,487 & 3,348 & 0.9 & 35 & 96 \\
\hline 여성가족부 & 12,001 & 9,588 & 79.9 & 62 & 155 \\
\hline 국토교통부 & 570,575 & 72,242 & 12.7 & 237 & 305 \\
\hline 해양수산부 & 61,628 & 13,175 & 21.4 & 168 & 78 \\
\hline 중소벤처기업부 & 168,240 & 1,633 & 1.0 & 12 & 136 \\
\hline 국가보훈처 & 58,350 & 44 & 0.1 & 3 & 15 \\
\hline 식품의약품안전처 & 6,110 & 651 & 10.7 & 15 & 43 \\
\hline 공정거래위원회 & 1,463 & 4 & 0.3 & 14 & 0.29 \\
\hline 경찰청 & 119,651 & 60 & 0.1 & 2 & 30 \\
\hline 소방청 & 2,208 & 356 & 16.1 & 8 & 45 \\
\hline 문화재청 & 11,416 & 5,803 & 50.8 & 57 & 102 \\
\hline 농촌진흥청 & 10,961 & 1,796 & 16.4 & 56 & 32 \\
\hline 산림청 & 25,282 & 11,327 & 44.8 & 101 & 112 \\
\hline 질병관리청 & 3,932 & 692 & 17.6 & 14 & 49 \\
\hline 행정중심복합도시건설청 & 4,344 & 96 & 2.2 & 3 & 32 \\
\hline 새만금개발청 & 2,962 & 60 & 2.0 & 3 & 20 \\
\hline
\end{tabular}

주: 1) 당초예산

2) 지방자치단체 국고보조금이 없는 부처는 표에서 제외하였으나 총지출 전체 값에는 포함되어 있음 자료: 이나라도움 참고 연구자 작성 


\section{2) 국고보조사업에서 공모방식의 확대}

최근 5년동안 공모형 국고보조사업의 숫자와 규모, 그리고 전체 국고보조사업비에서 차 지하는 비중이 계속 증가했다. 공모사업에서는 예산단위 내에서 집행되는 구체적인 개별사 업의 내용과 지출 결정에서 지방자치단체의 재량이 상대적으로 많다. 총사업비 기준으로 공모형 국고보조사업의 비중은 2016년 4.3\%에서 2020년 8.2\%로 두 배 정도 증가했다.

〈표 2-18〉 최근 5년간 공모형 국고보조사업의 기능별 분포

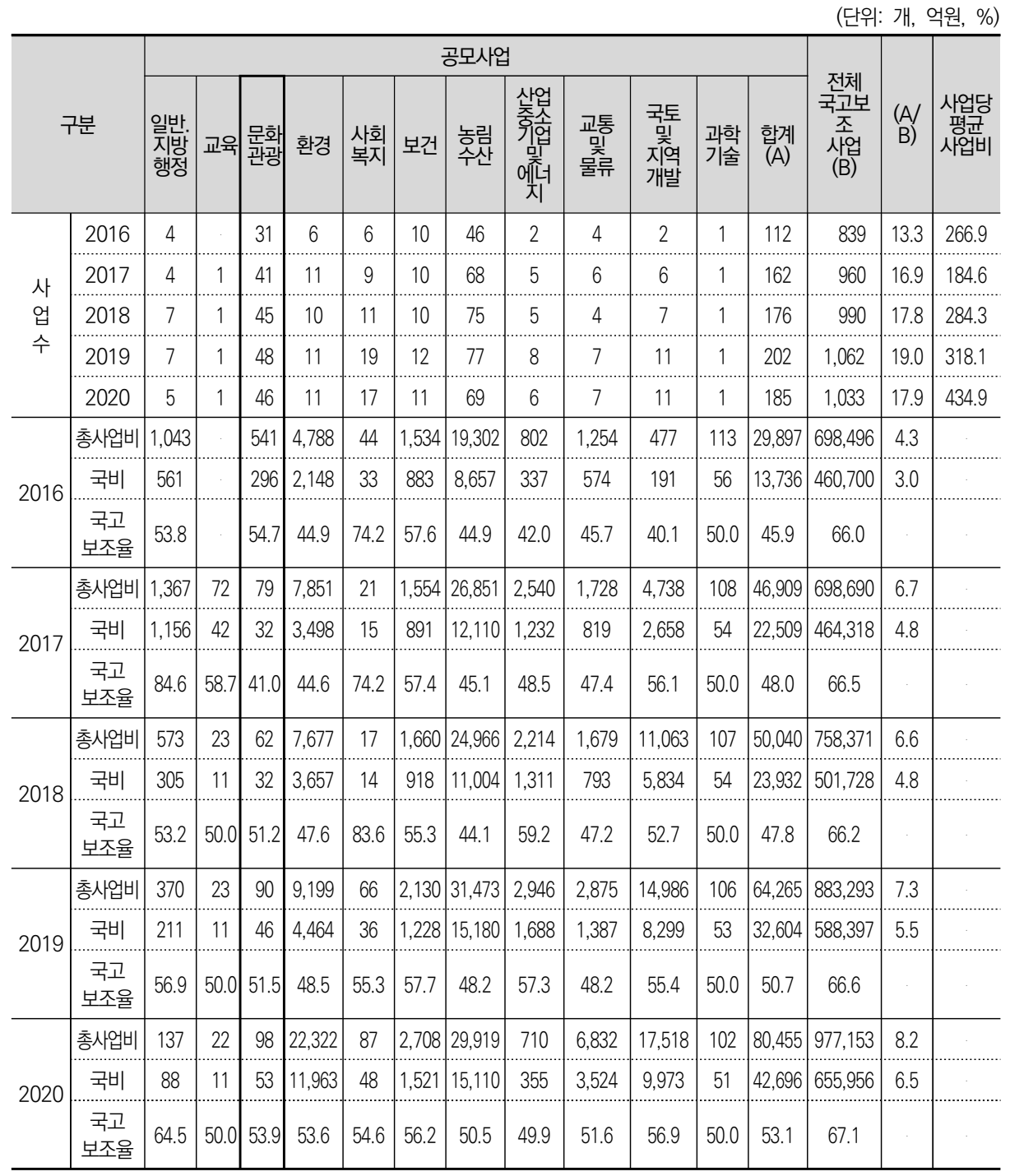

자료: 박병희·이재원·이종하(2020), 국고보조사업 분류체계 개편에 관한 연구. 한국지방재정공제회. 
공모형 사업에서는 소규모 예산사업들이 많다. 2020년 기준으로 사업당 평균총사업 비는 434.9억원이다. 재정기능별로 공모형사업의 분포를 살펴보면, 2020년 기준으로 문화관광분야는 공모형 보조사업이 많은 편인데, 2020년 기준으로 46개 사업이다. 총 사업비는 98억원으로 사업당 예산규모가 2.1억원에 불과하다. 사업수에서는 농림분야 의 사업이 가장 많은 69 개이고 총사업비는 3.0 조원,13) 환경분야는 11 개이지만 총사업 비는 2.2조원으로, 사업당 예산규모가 큰 편이다.

국고보조율은 대체로 낮은 수준이다. 2020년 기준으로 53.1\%인데, 전체 국고보조사 업에서 보조율이 $67.1 \%$ 인 점을 고려하면 상대적으로 낮다. 전체적으로 국고보조율이 $50 \%$ 대에 있는 공모사업이 89개로 가장 많고 문화관광과 농림수산 분야가 절반 이상을 차지한다. $70 \%$ 이상의 높은 보조율을 적용하는 사업은 32 개 뿐이다. 27 개 사업은 $40 \%$ 미만의 낮은 보조율을 적용받는데, 문화관광분야와 농림수산분야가 대부분을 차지한다. 13 개 공모형 사업은 전액 국비로 운영되며 환경분야가 가장 많은 5 개 사업이 있다.

〈표 2-19〉 공모형 국고보조사업의 국고보조율 분포(2020년)

(단위: 개, 억원, \%)

\begin{tabular}{|c|c|c|c|c|c|c|c|c|c|c|c|c|}
\hline & \multirow[b]{2}{*}{ 구분 } & \multicolumn{10}{|c|}{ 보조율구간 } & \multirow[b]{2}{*}{ 전체 } \\
\hline & & \multirow[t]{2}{*}{$\begin{array}{l}20 \% \\
\text { 미만 }\end{array}$} & \multirow[t]{2}{*}{$\begin{array}{l}20 \% \\
\text { 이상 }\end{array}$} & \multirow[t]{2}{*}{$\begin{array}{l}30 \% \\
\text { 이상 }\end{array}$} & \multirow[t]{2}{*}{$\begin{array}{l}40 \% \\
\text { 이상 }\end{array}$} & \multirow{2}{*}{$\begin{array}{c}50 \% \\
\text { 이상 } \\
4\end{array}$} & \multirow[t]{2}{*}{$\begin{array}{l}60 \% \\
\text { 이상 }\end{array}$} & \multirow[t]{2}{*}{$\begin{array}{l}70 \% \\
\text { 이상 }\end{array}$} & \multirow[t]{2}{*}{$\begin{array}{l}80 \% \\
\text { 이상 }\end{array}$} & \multirow[t]{2}{*}{$\begin{array}{l}90 \% \\
\text { 이상 }\end{array}$} & $100 \%$ & \\
\hline \multirow{11}{*}{$\begin{array}{l}\text { 기 } \\
\text { 능 }\end{array}$} & $\begin{array}{c}\text { 일반. } \\
\text { 지방행정 }\end{array}$ & & & & & & & & & & 1 & 5 \\
\hline & 교육 & & & & & 1 & & & & & & 1 \\
\hline & 문화관광 & & 2 & 1 & 6 & 30 & 2 & 3 & & & 2 & 46 \\
\hline & 환경 & ........ & ......... & 1 & ....... & 5 & .... & 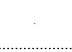 & ........... & ....... & 5 & 11 \\
\hline & 사회복지 & 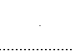 & 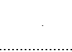 & 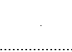 & 2 & 10 & 1 & 2 & 2 & 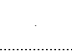 & 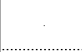 & 17 \\
\hline & 보건 & & & 1 & & 7 & 1 & 1 & & & 1 & 11 \\
\hline & 농림수산 & 1 & 4 & 16 & 15 & 19 & 3 & 5 & 1 & 2 & 3 & 69 \\
\hline & $\begin{array}{l}\text { 산업중소기 } \\
\text { 업및에너지 }\end{array}$ & & & & 2 & 1 & 1 & 1 & 1 & & & 6 \\
\hline & 교통및물류 & & & 1 & 2 & 3 & & 1 & & & & 7 \\
\hline & $\begin{array}{c}\text { 국토및지역 } \\
\text { 개발 }\end{array}$ & & & & & 8 & 2 & & & & 1 & 11 \\
\hline & 과학기술 & & & & & 1 & & & & & & 1 \\
\hline
\end{tabular}

13) 농림수산부문의 공모형 사업은 2016년 46개에서 지속적으로 증가하여 2019년에는 99개까지 급증했고, 2020년도에는 농림수산부문 균특회계 사업의 지방이양이 많아서 전체 사업수가 전년대비 감소했음. 


\begin{tabular}{|c|c|c|c|c|c|c|c|c|c|c|c|c|}
\hline & \multirow[b]{2}{*}{ 구분 } & \multicolumn{10}{|c|}{ 보조율구간 } & \multirow[b]{2}{*}{ 전체 } \\
\hline & & $\begin{array}{l}20 \% \\
\text { 미만 }\end{array}$ & \begin{tabular}{c|}
$20 \%$ \\
이상
\end{tabular} & $\begin{array}{l}30 \% \\
\text { 이상 }\end{array}$ & $\begin{array}{c}40 \% \\
\text { 이상 } \\
\end{array}$ & $\begin{array}{c}50 \% \\
\text { 이상 }\end{array}$ & $\begin{array}{c}60 \% \\
\text { 이상 }\end{array}$ & $\begin{array}{l}70 \% \\
\text { 이상 }\end{array}$ & $\begin{array}{l}80 \% \\
\text { 이상 }\end{array}$ & $\begin{array}{l}90 \% \\
\text { 이상 }\end{array}$ & $100 \%$ & \\
\hline & 전체 & 1 & 6 & 20 & 27 & 89 & 10 & 13 & 4 & 2 & 13 & 185 \\
\hline \multirow{2}{*}{$\begin{array}{l}\text { 규 } \\
\text { 모 }\end{array}$} & 총사업비 & 29,493 & 169,664 & $1,174,661$ & 461,965 & $4,880,859$ & 296,190 & 862,036 & 72,024 & 7,296 & 91,272 & $8,045,459$ \\
\hline & 국비 & 4,200 & 42,137 & 404,758 & 211,014 & $2,648,977$ & 193,719 & 608,833 & 57,919 & 6,781 & 91,272 & $4,269,610$ \\
\hline 비 & 총사업비 & 0.4 & 2.1 & 14.6 & 5.7 & 60.7 & 3.7 & 10.7 & 0.9 & 0.1 & 1.1 & 100.0 \\
\hline 중 & 국비 & 0.1 & 1.0 & 9.5 & 4.9 & 62.0 & 4.5 & 14.3 & 1.4 & 0.2 & 2.1 & 100.0 \\
\hline
\end{tabular}

자료: 박병희·이재원·이종하(2020), 국고보조사업 분류체계 개편에 관한 연구. 한국지방재정공제회.

공모형 사업은 지방자치단체가 상향식으로 신청하고, 지방의 현장 다양성을 고려한 맞춤형 사업으로 운영되고 국가 전체적으로 표준화되어야 하는 기초보조사업이 아니기 때문에 전반적으로 국고보조율이 낮은 편이다.

최근 5년동안 공모형 보조사업의 보조율은 약간 증가하는 추세인데, 연도별로 불규칙 적인 편이다. 사회복지분야의 보조율에서 변화가 특히 크며 점차 낮아졌다. 환경분야와 농림분야의 보조율은 비교적 안정적으로 증가하는 추세에 있고 문화관광분야는 불규칙 성이 상대적으로 심한 편이다.

[그림 2-4] 최근 5년간 공모형 국고보조사업의 국고보조율 추이

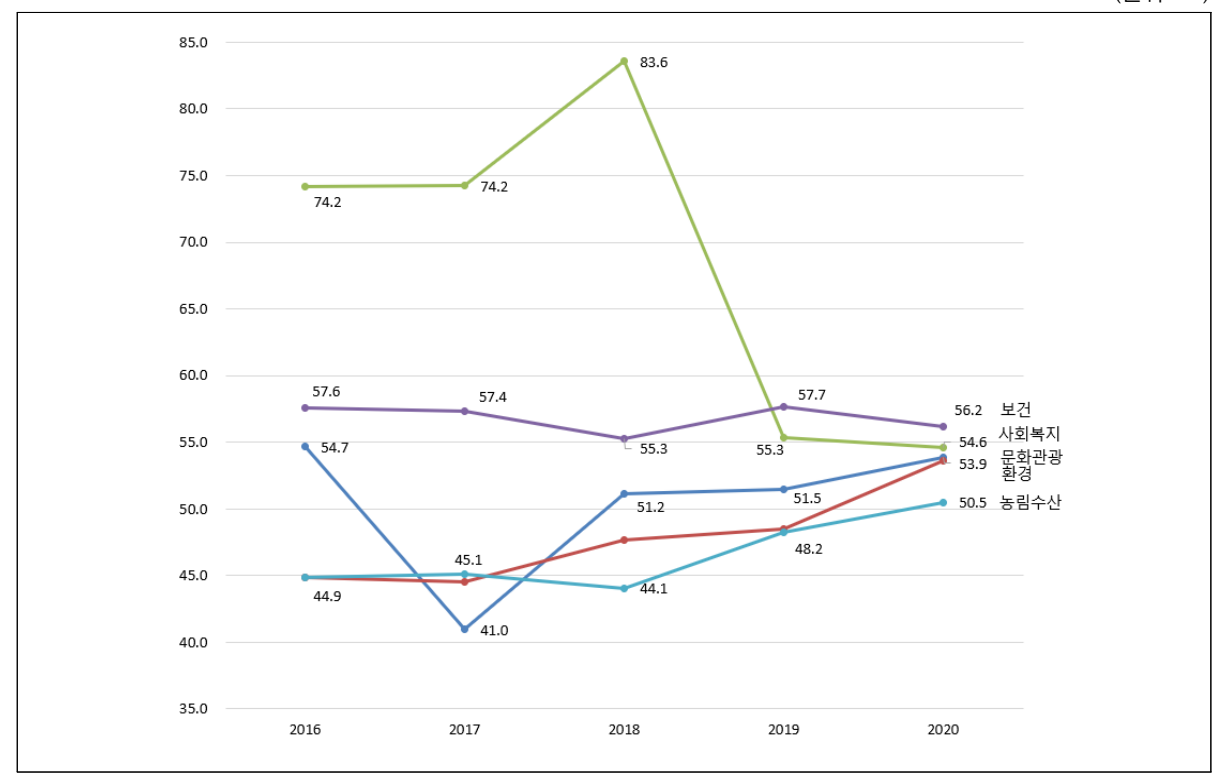

자료: 박병희·이재원·이종하(2020), 국고보조사업 분류체계 개편에 관한 연구. 한국지방재정공제회. 
공모형 사업은 국고보조사업의 지역 맞춤형 지원이라는 점에서 재원배분의 효율성을 높일 수 있는 장점이 있다. 하지만, 지방자치단체들 간에 국비 사업 유치를 위한 약탈적 경쟁 상황이 발생하면, 지방비 부담이 과도하게 발생할 재정위험이 있다. 사업관리에서 도 공모형 사업은 장단점이 있다. 지방자치단체가 재량으로 선택한 사업이기 때문에 사 업의 관리와 성과에 대한 책임이 높아질 수 있다. 그러나 국고보조사업이기 때문에 중앙 정부 소관부처의 관리 감독 기능이 느슨하면 기대만큼 효율성 혹은 효과성을 창출하지 못하고, 도덕적 해이 쟁점이 발생한다. 순환보직 이동의 인사관행이 중앙과 지방에서 동 시에 발생하면 임의적으로 선정·추진되는 공모형 사업의 경우 책임의 주체가 불분명해 지는 문제가 발생한다.

\section{3. 지역문화 정책의 여건 변화}

\section{가. 지역문화정책 기반확충}

지방자치제 이후 지역의 경쟁력 강화 요구, 주민의 지역정책에 대한 관심 확대 등은 지역별 특성화된 문화정책을 필요로 하였고, 문화기획 및 문화시설 경영능력과 민관 협 력은 문화분권의 기본 전제가 되었다. 지방자치단체의 문화분권 역량은 지방자치단체 단 체장을 포함한 담당 공무원의 지역문화에 대한 이해와 의지, 문화사업 담당인력의 기획 능력 및 전문성, 정부 간, 민관 간, 민간과 민간 협력과 조정 능력 등을 포함한다.

이러한 문화분권 역량강화를 위해 광역지방자치단체는 물론 기초자치단체에서 지역 문화재단을 설립하면서 지역 중심의 문화정책 기반을 형성하려는 노력이 있었다. 1997 년 경기문화재단 설립을 시작으로 2019년 기준 전국 226개 자치단체 중 92개 문화재단 (광역 16 개, 기초 76 개)이 운영되고 있는데, 문화재단은 지역의 문화사업의 주요 수행 주체로 활동하여 왔다. 지역문화재단은 문화사업 전문기관으로서 지역성이 반영된 문화 정책 수립 및 집행, 전문인력양성을 통한 지역문화사업 전문성 확보에 중요한 역할을 하고 있다. 또한 전국 230개 지방문화원이 지역의 향토문화 보존과 전승을 위한 사업을 추진하고 있다.

한편 2015년부터 지역사회 내에서 생활문화 거점공간 조성을 통해 주민이 일상속에 서 쉽게 문화를 즐기고 나눌 수 있는 활성화 여건을 마련하고자 생활문화센터 조성사업 
을 추진하였다. 지역민의 생활문화 활동 거점공간으로 활용되고 있는 생활문화센터는 2014년 34개소에서 매년 확대하여 현재 전국 191개소가 조성되어있다. 이로서 지역주 민 및 지역 수요에 적합한 문화서비스를 제공할 수 있는 공간이 확보되었다. 도서관, 미 술관과 같은 문화시설은 지역의 특성을 살려 보다 지역 친화적이고 접근하기 편리하도 록 복합화를 지향하였고, “작은" 미술관, 도서관, 영화관 등 조성이 확대되었다. 지역의 공공도서관은 344 개관, 작은도서관은 408 개관, 작은미술관은 14 개관이 운영되고 있다.

지역의 문화자원과 폐산업시설 등 유휴공간을 문화적으로 리모델링하여 지역을 문화 적 특색있는 장소로 변모하기도 하는데, 문화적 리모델링은 전국 약 30 개소가 추진되었 고, 약 80여개의 문화마을이 조성되어 있다.

\section{나. 지자체 문화정책 계획수립 경험 축척}

지역 자체적으로 문화정책 중기계획을 수립한다는 것은 지역의 문화적 여건을 검토하 고 지역에 차별화된 사업을 기획하며 중장기 관점에서 사업의 성과에 관심을 가질 수 있다는 점에서 의미가 깊다. 2014년 제정된 「지역문화진흥법」에 근거하여 전국 시도 단 위에서 자체적으로 지역문화진흥을 위한 시행계획을 수립하게 되었다. 그리고 같은 법에 서 지역문화수준을 파악하고 발표하는 지역문화실태조사(승인통계 명: 지역문화현황통 계)가 있는데 지역 간 문화격차 현황 등 지역문화진흥에 필요한 사항을 조사하고자 지역 문화실태조사를 5년마다 실시할 수 있다. 이를 근거로 2013년, 2015년, 2019년 3회에 걸쳐 조사가 실시되었다. 현재의 지역문화실태조사는 229 개 시군구별 문화정책·자원. 활동·향유 측면의 표준화된 지역문화 현황 자료를 제공하여 중앙정부와 지방자치단체 정책진단의 중요한 기초자료가 되고 있다.

한편 지방자치단체 문화정책의 역량을 증진하고 성과를 담보하기 위해서는 인적자원 이 매우 중요한다는 인식이 공유되면서 각종 인력양성, 역량강화 등 교육훈련과 네트워 크 프로그램에 정책적 지원이 확대되었다. 지역의 문화 기초역량 강화를 위한 '지역문화 전문인력 양성'사업은 2015년 시작되어 지역을 기반으로 활동하는 문화관련 전공자 등 문화인력이 문화시설 실무자로 근무할 수 있도록 교육/훈련을 제공하였다. 지역문화 현 장에 필요로 하는 기획, 개발, 평가 등의 업무를 수행하는데 필요한 지식과 경험을 제공 하는 등 실무형 전문가로 양성하였고, 이를 통해 양성된 지역문화기획가는 2019년 
1,173 명 배출되었다. 더불어 대부분의 지방자치단체에 운영되고 있는 지역문화재단 종 사자 직무역량 강화를 위한 교육을 추진하여, 지역 문화사업 추진 주체들의 역량강화와 경험을 축척해왔다. 

지역문화 성과협약형 포괄보조 방식 도입방안 연구

제3장

포괄보조 방식 사례 



\section{제1절 농촌협약(농식품부)}

\section{1. 사례개요}

\section{가. 농촌협약 개념}

농촌협약은 2020년 시범도입된 제도로 시·군 주도로 농촌생활권에 대한 발전방향을 수립하면, 농림축산식품부와 시·군이 협약을 체결하고 공동으로 투자함으로써 365 생활 권 조성 등 공통의 농촌정책 목표를 달성하도록 설계된 제도이다. 농림축산식품부 장관 과 시장-군수가 협약주체이고 '농촌생활권 활성화계획'에 대해 5 년 기간동안 최대 국비 300 억원 규모를 투자하며, 농림축산식품부와 지방자치단체 간 사업내용 및 투자부담, 성과목표 등에 대한 문서 상 합의로 협약 내용에 따른 이행 의무가 발생한다.

[그림 3-1] 농촌협약 기본 개념도

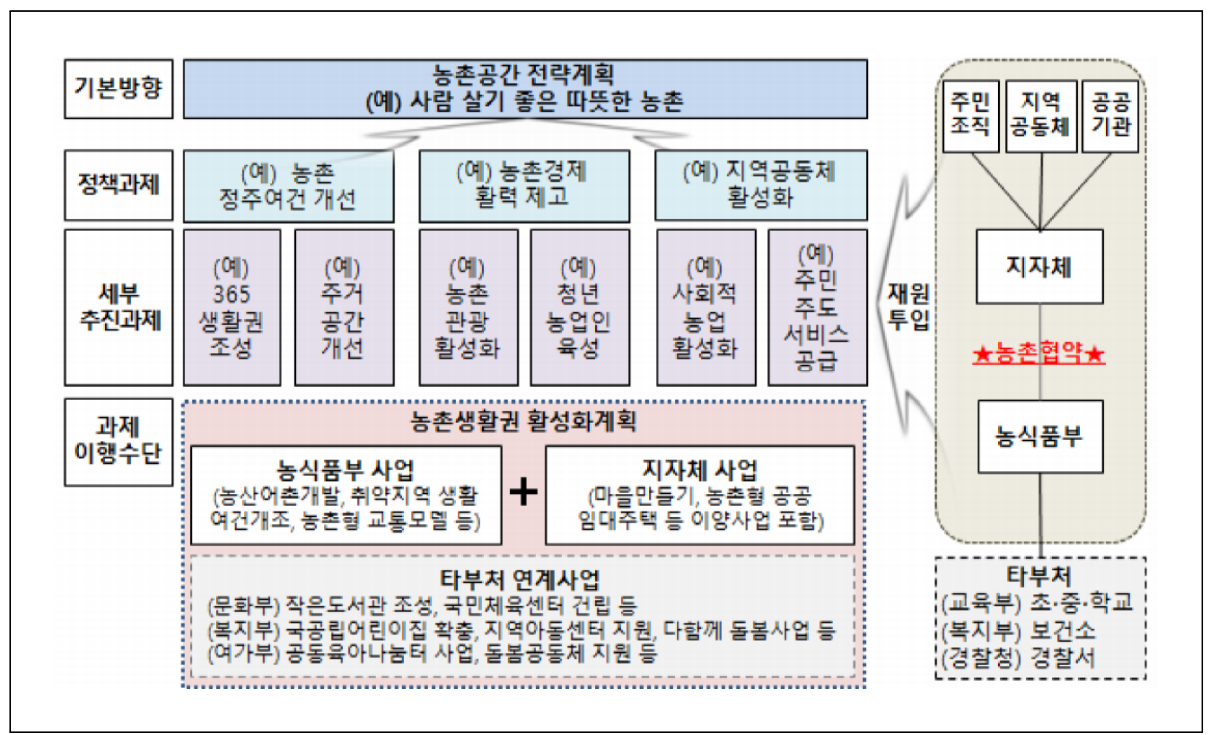

자료: 2021년도 농촌협약 설명회 자료 
〈표 3-1〉 농촌협약 개요

\begin{tabular}{|c|c|}
\hline 구분 & 내용 \\
\hline 협약주체 & $\begin{array}{l}\text { 농식품부 장관과 시장.군수가 협약의 직접 당사자 } \\
\text { - 지자체 계획 수립 및 사업 추진 지원을 위한 중간지원조직, 민간 주체, 공공기관 등 핵심 } \\
\text { 관계자도 협약의 당사자로 참여 } \\
\text { - 시장 도지사도 협약의 당사자로 참여 가능(시 도비 투자 시) }\end{array}$ \\
\hline 협약내용 & $\begin{array}{l}\text { 통합적 사업추진계획인 ‘농촌생활권 활성화계획' } \\
\text { - 활성화계획에 포함되는 구체적 사업은 ‘농촌공간 전략계획’, 농발계획 등 지역의 중장기 } \\
\text { 비전에 기반하여 구성 } \\
\text { - 농촌분야 농식품부 지원사업, 지자체 자체사업, 지방이양사업, 공공기관 민간 투자사업 등을 } \\
\text { 모두 활성화계획에 포함할 수 있음 }\end{array}$ \\
\hline 협약기간 & 5년 \\
\hline 협약예산 & 국비 최대 300억/개소 $+\alpha$ (인센티브) \\
\hline 협약효력 & $\begin{array}{l}\text { 농식품부와 지자체간 사업 내용 및 투자 부담, 성과목표 등에 대한 문서상 합의로 협약내용에 } \\
\text { 따른 이행 의무 발생 }\end{array}$ \\
\hline
\end{tabular}

\section{나. 추진배경}

자치분권 강화로 읍면 소재지와 함께 정주생활권을 구성하는 배후마을 정책 기능이 지방으로 이양됨에 따라 새로운 정책 거버넌스가 요구되었다.14) 지방이양결정으로 하나 의 정책 대상(정주 생활권)에 정책 주체가 이원화되었는데, 읍면 소재지 거점 개발은 중 앙이 배후마을 정주여건 개선은 지방자치단체가 전담하게 되었다. 이로 인해 중앙과 지 방이 '농촌 생활권 복원' 이라는 공통의 정책 목표 하에 정책 수단을 연계·보완하기 위해 서는 중앙과 지방의 협력이 중요해졌다.

한편 농촌 공간에 대한 종합적 계획과의 연계성 없이 개별 사업단위의 투자가 반복되 면서 농촌정책의 성과목표 측정과 정책성과 창출에 한계가 발생하였다. 시·군 단위 다수 의무·임의 계획이 중복·산발적으로 수립되고 있으나 사업 간 연계되지 못하고 사업추진 평가는 누락되는 등 정책실효성이 저조하였다. 이에 농촌생활권에 대한 정책 주체인 중 앙과 지방 간 협력체계를 구축하고, 지역 주도의 농촌 정책 추진 기반을 갖추고자 농촌 협약 제도가 도입되었다.

농촌협약은 농촌의 읍·면 소재지, 마을 등에 대한 점(點) 단위 투자에서 공간(面) 단위 로 투자범위를 확대하여, 사업 간 연계·복합화를 통한 시너지 효과를 창출할 것으로 기

14) 농식품부 지역개발과 (2019) 2020 2021 농촌협약 추진계획 p. 1 
대된다. 장기적으로 농촌협약은 현재 도입을 검토 중인 '농촌공간계획'과 연계 운영될 예정이며, 대상 정책의 범주도 '농촌'에서 '농업' 등으로 확대해 나갈 계획이다.

\section{다. 현황}

농림축산식품부는 시·군을 대상으로 2020년 농촌협약 시범도입 시·군 선정 공모(1차 '19.12.20. '20.1.17, 25개소 응모/2차 4.17. 6.10, 19개소 응모)를 진행하였고, 관 련 전문가로 구성된 평가위원회의 평가를 거쳐 총 9 개의 시범도입 시·군과 3 개의 예비 도입 시·군(이천시, 영월군, 괴산군)을 선정하였다. 시범도입 지방자치단체는 9개로 홍 성군, 임실군, 원주시, 영동군, 순창군, 보성군, 상주시, 김해시, 밀양시 등이 선정되었고, 예비도입 지방자치단체는 총 3개로 이천시, 영월군, 괴산군 등이다.

2022년 농촌협약 대상으로 2021년도에 일반농산어촌지역 시·군 113 개 중 20개(시· 군 17 개, 예비 시·군 3개)를 선정하였다. 총 43개 시·군이 신청해 약 2.2:1(2020년 1.9:1) 수준의 경쟁률을 보였다.

농촌협약 대상 시·군은 안성시, 평창군, 제천시, 청양군, 금산군, 무주군, 진안군, 김제 시, 화순군, 나주시, 봉화군, 청도군, 군위군, 고령군, 산청군, 합천군, 고성군이며, 예비 시·군은 강진군, 음성군, 장흥군이다. 예비시군은 농촌협약 대상 17 개 시·군 중 선정 취 소 또는 포기 등에 대비하여 추가 선정되었지만, 선정 취소 또는 포기가 없는 경우에는 계획서 보완 수준, 예산규모 등을 감안하여 협약체결 지원 예정이다.

〈표 3-2〉 2022년 농촌협약 대상 지자체

\begin{tabular}{c|c|c|c|c|c|c|c}
\hline 경기(1) & 충북(2) & 경북(4) & 전북(3) & 강원(1) & 충남(2) & 경남(3) & 전남(4) \\
\hline \multirow{3}{*}{ 안성 } & 제천, (음성) & $\begin{array}{c}\text { 봉화, } \\
\text { 청도, } \\
\text { 군위, } \\
\text { 고령 }\end{array}$ & $\begin{array}{c}\text { 무주, } \\
\text { 진안, } \\
\text { 김제 }\end{array}$ & 평창 & 청양, 금산 & $\begin{array}{c}\text { 산청, 합천, } \\
\text { 고성 }\end{array}$ & $\begin{array}{c}\text { 화순, 나주, } \\
\text { (장흥), } \\
\text { (강진) }\end{array}$ \\
\hline
\end{tabular}

주: ( )는 예비 시·군

자료: 농림축산식품부 보도자료(2021.6.16.) 2022년 농촌협약대상 20개 시·군 선정 


\section{2. 운영방식}

\section{가. 추진절차}

협약신청은 시·군에서 농림축산식품부로 전략계획 및 활성화계획을 제출하고, 농림축 산식품부는 위원회를 구성하여 평가 후 협약대상 지방자치단체를 선정하고 협약을 체결 한다. 평가위원회에서 시·군의 전략·활성화계획(예비)에 대한 발표 및 질의응답 내용을 평가하여 도입 시·군을 선정한다. 다음으로 평가의견과 중앙계획지원단 협의 결과 등을 반영하여 전략계획을 보완하고, 평가의견, 중앙계획지원단 협의결과, 농림축산식품부 의 견 등을 반영하여 활성화계획을 보완한다. 농림축산식품부 농촌정책국은 지원사업 내용 을 검토·조정하여 모든 사업의 지원요건을 충족하는 경우 활성화계획을 승인하고, 농림 축산식품부와 시·군은 활성화계획을 대상으로 협약을 체결한다.

〈표 3-3〉 농촌협약 추진단계(2021년 기준)

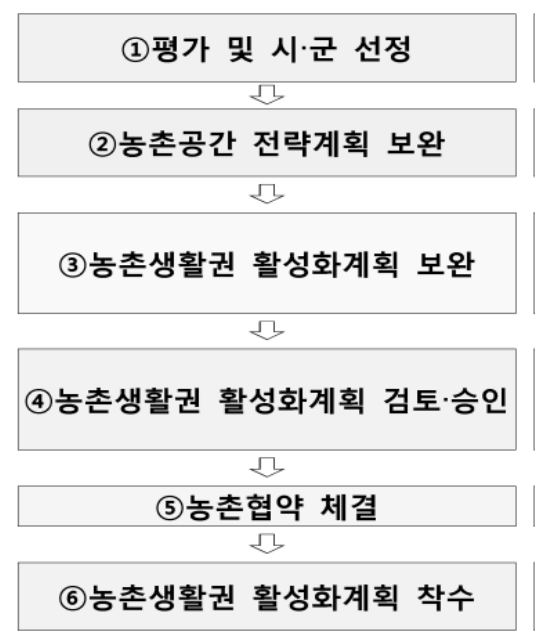

- 전략·활성화계획(예비) 지자체 발표 및 질의응답 내용을 평가

'21.5 6

- 전문가 등 협의·자문 등을 통해 전략계획을 수정·보완

'21.6 8

전문가 등 협의·자문 등을 통해 활성화계획을 수정·보완 - 농식품부 사업부서의 의견수렴·반영

농촌정책국 정책협의회(사업부서로 구성)에서 사업내용 검토·조정 후 승인 - 대상 사업 및 국비 규모 확정

'21.11

- 농식품부, 사군, 사도 등 간 협약 체결

'21.12

- 기본계획 수립, 부지매입, 설계 등 착수 - 일반농산어촌개발사업비 등 투자

'22.1

자료: 농림축산식품부(2021.2) 2021년 농촌협약 추진계획

시·군은 협약을 위해 반드시 마을만들기사업을 포함한 지방이양사업 추진계획, 농발계 획과 농촌재생뉴딜사업 연계 강화를 위해 '농촌공간정비계획' 을 포함한 전략·활성화 계획 (예비)을 수립해야 한다. 생활권에 대한 분석을 바탕으로 지역의 중장기 발전을 위한 비전, 목표, 향후 개선방향 등을 포함한 '농촌공간 전략계획' 을 수립하고, 전략계획을 바탕으로 각 생활권별로 구체적인 추진과제를 담은 '농촌생활권 활성화 계획'을 수립해야 한다. 


\section{나. 협약내용}

시·군은 지역주민들이 문화·교육·복지 등의 서비스를 향유하는 공간적 범위(생활권) 을 구분하고, 가장 서비스 접근성이 낮고 취약한 생활권을 대상으로 정주여건 개선 등 다양한 정책과제를 설정하여 '농촌생활권 활성화계획('21 '25)'을 수립하게 된다. 활성 화계획에 포함되는 구체적 사업은 '농촌공간 전략계획', 농발계획 등 지역의 중장기 비 전에 기반하여 구성하고, 농림축산식품부의 농촌분야 지원사업 및 지방이양사업과 연계 하여 기획되어야 한다.

[그림 3-2] 농촌공간 전략계획 및 농촌생활권 활성화계획 개념도

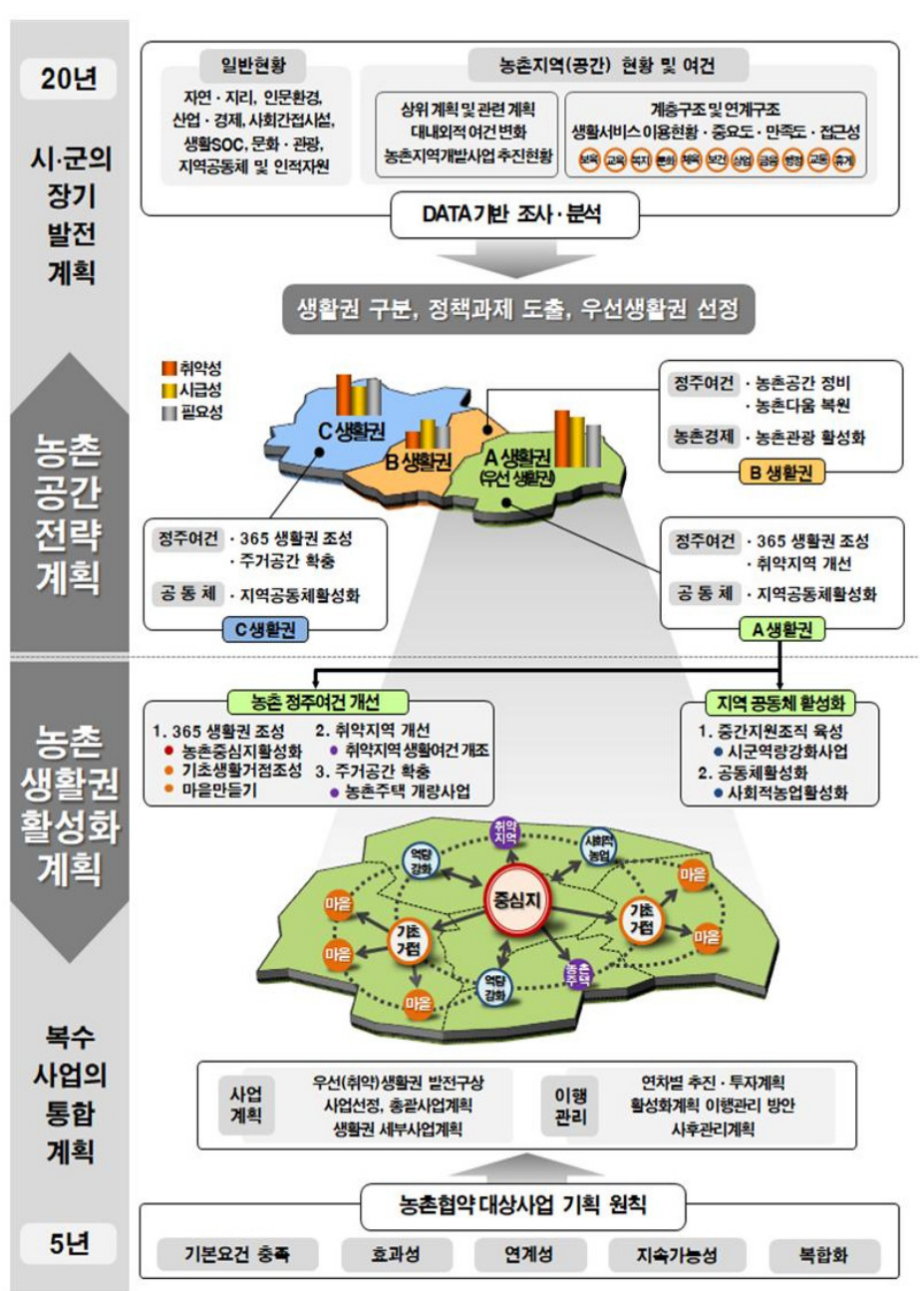


농촌협약 정책과제 및 사업 예시는 다음과 같다. 농림축산식품부 소관 사업에 대해 지방자치단체와 협약을 체결하고 패키지 지원하지만 농촌협약 사업 대상 이외 타부처 연계사업을 발굴·계획할 수 있다.

〈표 3-4〉 농촌협약 정책과제 및 사업 예시

\begin{tabular}{|c|c|c|}
\hline 정책과제(안) & 세부과제(안) & 과제이행수단(사업) 예시 \\
\hline \multirow[t]{5}{*}{ 1. 농촌정주여건 개선 } & (1) 365생활권 조성 & $\begin{array}{l}\text { - 농촌중심지활성화(농식품부) } \\
\text { - 기초생활거점조성(농식품부) } \\
\text { - 마을만들기(지자체) } \\
\text { - 농촌형교통모델(농식품부) } \\
\text { - 농촌보육여건개선(농식품부) } \\
\text { - 생활문화센터조성사업(문화부) } \\
\text { - 작은도서관조성지원사업(문화부) } \\
\text { - 국민체육센터건립지원(문화부) } \\
\text { - 국공립어린이집확충(복지부) } \\
\text { - 다함께돌봄사업(복지부) } \\
\text { - 농어촌의료서비스개선사업(복지부) } \\
\text { - 공동육아나눔터사업(여가부) } \\
\text { - 전통시장주차환경개선사업(중기부) } \\
\text { - 온종일돌봄체계구축(교육부) } \\
\text { - 신재생에너지보급지원(에너지공단) }\end{array}$ \\
\hline & (2) 농촌공간계획 & $\begin{array}{l}\text { - 농촌뉴딜(농식품부) } \\
\text { * 예산확보 여부에 따라 결정 }\end{array}$ \\
\hline & (3) 취약지역 개선 & $\begin{array}{l}\text { - 취약지역생활여건개조(농식품부) } \\
\text { - 슬레이트처리지원사업(환경부) }\end{array}$ \\
\hline & (4) 주거공간 확충 & $\begin{array}{l}\text { - 농촌주택개량사업(농식품부) } \\
\text { - 청년농촌보금자리조성(농식품부) } \\
\text { - 귀농귀촌공공주택사업(LH) }\end{array}$ \\
\hline & (5) 농촌다움 복원 & $\begin{array}{l}\text { - 농촌다원적자원활용(농식품부) } \\
\text { - 경관보전직불(농식품부) }\end{array}$ \\
\hline \multirow[t]{2}{*}{ 2. 농촌경제 활력 제고 } & $\begin{array}{l}\text { (1) 지역특화향토산업육성/ } \\
\text { 6차산업활성화 }\end{array}$ & $\begin{array}{l}\text { - 신활력플러스(농식품부) } \\
\text { - 농촌융복합산업활성화지원(농식품부) } \\
\text { - 농촌유휴시설활용창업지원(농식품부) } \\
\text { - 농촌자원복합산업화지원(지자체) } \\
\text { - 특성화시장육성사업(중기부) } \\
\text { - 메이커스페이스구축사업(중기부) }\end{array}$ \\
\hline & (2) 농촌관광활성화 & $\begin{array}{l}\text { - 농촌융복합산업활성화지원(농식품부) } \\
\text { - 농촌자원복합산업화지원(지자체) }\end{array}$ \\
\hline \multirow{3}{*}{ 3. 지역공동체 활성화 } & (1) 중간지원조직·육성 & - 시·군역량강화(농식품부) \\
\hline & $\begin{array}{l}\text { (2) 지역공동체/ } \\
\text { 사회적경제활성화 }\end{array}$ & $\begin{array}{l}\text { - 사회적농업활성화(농식품부) } \\
\text { - 농촌공동체활성화사업(농식품부) } \\
\text { - 귀농귀촌활성화(농식품부) }\end{array}$ \\
\hline & $\begin{array}{l}\text { (3) 지역사회 주도 } \\
\text { 생활서비스 공급망 구축 }\end{array}$ & $\begin{array}{l}\text { - 취업농가인력지원(농식품부) } \\
\text { - 청년공동체활성화사업(행안부) } \\
\text { - 비영리민간단체공익활동지원사업(행안부) }\end{array}$ \\
\hline
\end{tabular}

주: 1) 음영은 필수 정책 및 세부과제를 의미함

2) 365 생활권은 30 분 내 기초생활서비스, 60 분 내 복합서비스 접근성 보장, 5 분 내 응급상황 대응체계 구축을 의미 자료: 농림축산식품부(2021.2) 2021년 농촌협약 추진계획 
협약하고자 하는 시·군은 '농촌재생뉴딜사업' 연계 강화를 위해 '농촌공간정비계획'을 포함한 전략·활성화 계획(예비)을 수립해야 한다. '22년 '농촌재생뉴딜사업'은 '21년 농 촌협약 선정 시·군을 대상으로 사업이 추진될 예정이다. 협약대상 계획인 '농촌생활권 활성화 계획' 은 기존계획과 연계하고 협약 전담조직을 운영하는 것을 전제조건으로 두고 있다. 활성화 계획은 마을만들기사업을 포함한 지방 이양사업을 연계하여 기획해야 하 고, 지역의 장기 계획인 농촌공간 전략계획 및 농발계획과 연계되어야 한다.

그리고 시군 및 시도에 협약을 담당하는 전담조직(부서)을 두고, 협약 당사자 등으로 구성된 농촌협약 위원회를 조직하며, 농촌협약 이행을 지원하는 중간지원조직을 운영해 야 한다. 전담조직은 농촌지역개발사업을 총괄하는 부서(행정기구 설치·운영 조례의 최 소단위)로 농촌협약의 기획, 신청, 시행, 준공, 사후관리까지 전 과정을 담당하는 곳이다. 부서장을 제외하고 최소 5 인 이상으로 구성하고, 부서에서 활성화계획에 포함된 과제의 이행을 담당하는 인원(5인 이상)이 과반수를 차지하거나, 그 외 나머지 인원이 모두 과제 이행과 연관된 업무를 추진해야 한다.

사업선정 기준은 시·군이 시·도를 통해서 제출한 농촌협약 신청서, 농촌공간 전략계 획(예비), 농촌생활권 활성화 계획(예비, 농촌공간정비계획 포함) 등 제반서류를 근거로 평가한다. 중앙평가, 농촌계획, 농촌지역개발, 산업 등 관련 외부 전문가 5 인 내외로 구 성된 평가위원회에서 평가지표에 따라 전략 계획(배점 $60 \%$ ), 활성화계획(농촌공간정비 계획 포함, 40\%)에 대해 대면 평가 후 점수를 합산해 시·군을 선정한다.

추가적으로 균형 발전사업임을 고려해 농촌지역의 균형발전을 위해 협약 도입 시·군이 가급적 특정 시·도에 편중되지 않도록 고려한다. 읍·면 소재지, 배후마을 등 빈집 정비를 정책과제에 포함하는 경우 평가 시 가산점 부여하고, 농촌협약 신청서 제출 전까지 모든 전 제조건을 이행하는 경우, 지방자치단체의 협약 도입.이행 의지를 고려하여 가점 부여한다.

1) 평가항목 (농촌 공간 전략계획, 배점 $60 \%$ )

〈표 3-5〉 평가항목 농촌 공간 전략계획, 기본항목(600점)

\begin{tabular}{c|c|l}
\hline 평가항목 & 세부항목 & \multicolumn{1}{c}{ 평가내용 } \\
\hline \multirow{3}{*}{ 전략계획의 } & 일반현황 및 여건 & - 자연·인문·환경 및 산업·경제 등 현황 조사·분석 결과의 간결성·충실성 \\
타당성 (360 점) & 조사·분석 (60) & $\begin{array}{l}\text { 솽SOC 시설 분포·운영현황 조사·분석 결과의 충실성 } \\
\text { - 지역공동체 및 인적자원 조사·분석의 충실성 }\end{array}$ \\
\hline
\end{tabular}




\begin{tabular}{|c|c|c|}
\hline 평가항목 & 세부항목 & 평가내용 \\
\hline & $\begin{array}{l}\text { 농촌공간 현황 및 } \\
\text { 여건 조사·분석 } \\
\text { (90) }\end{array}$ & $\begin{array}{l}\text { - 상위·관련계획 및 대내외 여건 변화 고려 시 농촌공간 전망 결과의 } \\
\text { 적정성 } \\
\text { - 계층·연계구조, 서비스 이용현황 분석결과 등을 종합적으로 고려해 } \\
\text { 도출한 농촌공간 구조 현황의 적정성 } \\
\text { - 종합분석 결과에서 도출한 농촌공간의 특성 및 시사점의 타당성 }\end{array}$ \\
\hline & $\begin{array}{l}\text { 계획의 기본방향 } \\
\quad \text { 설정 }(120)\end{array}$ & $\begin{array}{l}\text { - 현황분석 결과를 바탕으로 도출한 비전 및 목표, 주요 지표의 적정 } \\
\text { 성·타당성 } \\
\text { - 농촌 공간 구조 현황을 바탕으로 설계한 생활권 설정 결과의 적정성- } \\
\text { 타당성 } \\
\text { - 생활권별 상위거점-하위거점-배후마을 설정의 적정성·타당성 } \\
\text { - 현황분석 결과를 바탕으로 도출한 정책과제 및 세부추진과제, 과제 } \\
\text { 추진방안의 타당성 }\end{array}$ \\
\hline & $\begin{array}{l}\text { 농촌공간 발전계획 } \\
\quad \text { 수립(90) }\end{array}$ & $\begin{array}{l}\text { - 농촌생활권별 발전 구상 결과의 적정성·타당성 } \\
\text { - 우선순위 부여를 통한 농촌협약 대상 생활권 설정의 적정성 } \\
\text { - 생활권 내 거점과 배후마을 간, 생활권 간 연계 방안의 적정성 }\end{array}$ \\
\hline \multirow{2}{*}{$\begin{array}{l}\text { 지자체의 추진 } \\
\text { 의지·준비도 } \\
\text { (120점) }\end{array}$} & $\begin{array}{c}\text { 행정의 } \\
\text { 의지·준비도(60) }\end{array}$ & $\begin{array}{l}\text { - 전담부서 구성현황 또는 구성계획의 적정성 } \\
\text { - 시·군 내 유관부서 간 협의채널 구축 현황 및 적정성 }\end{array}$ \\
\hline & $\begin{array}{l}\text { 협력관계 구축 } \\
(60)\end{array}$ & $\begin{array}{l}\text { - 농촌협약 위원회 구성현황 및 적정성 } \\
\text { - 농촌협약 지원센터9중간지원조직) 구성현황 및 적정성 }\end{array}$ \\
\hline \multirow{2}{*}{$\begin{array}{l}\text { 투자 및 관리 } \\
\text { 운영계획의 실현 } \\
\text { 가능성 } \\
\text { (90점) }\end{array}$} & $\begin{array}{l}\text { 투자계획의 } \\
\text { 실현 가능성 } \\
\quad(30)\end{array}$ & $\begin{array}{l}\text { - 재정현황을 고려 시 재원조달 계획의 이행가능성 } \\
\text { - 생활권별·부문별 투자계획의 적정성·이행가능성 }\end{array}$ \\
\hline & $\begin{array}{l}\text { 운영계획의 } \\
\text { 지속가능성 } \\
\quad(60)\end{array}$ & $\begin{array}{l}\text { - 지역사회 민간주체의 자립 가능성 } \\
\text { - 지역사회 주도의 서비스 공급전달체계의 지속가능성 }\end{array}$ \\
\hline $\begin{array}{l}\text { 농촌협약의 } \\
\text { 도입 필요성 } \\
\text { (30점) }\end{array}$ & - & - 제시된 생활권에서의 농촌협약 추진 필요성 \\
\hline
\end{tabular}

자료: 농림축산식품부(2021.2), 2021년 농촌협약 추진계획

〈표 3-6〉 평가항목 농촌 공간 전략계획 평가항목 가감점 항목( \pm 30 점)

\begin{tabular}{|c|c|}
\hline 평가항목 & 평가내용 \\
\hline $\begin{array}{c}\text { 가점 } \\
(\text { 최대+30) }\end{array}$ & $\begin{array}{l}\text { - 정책과제 및 세부추진과제에 빈집 정비를 포함하는 경우 } \\
\text { 신청서 제출 전 모든 전제조건을 이행한 경우 } \\
\text { 시·군에서 민관 협의채널로 농촌협약 협의회를 구성·운영하는 경우 } \\
\text { 광역 또는 기초단위 중간지원조직을 통합 운영 중인 경우 }\end{array}$ \\
\hline $\begin{array}{c}\text { 감점 } \\
\text { (최대 }-30)\end{array}$ & $\begin{array}{l}\text { - 평가 안내 사항 준수 여부 } \\
\text { 증빙자료 및 제반 서류의 진위성 }\end{array}$ \\
\hline
\end{tabular}

자료: 농림축산식품부(2021.2), 2021년 농촌협약 추진계획 
2) 평가항목 (농촌생활권 활성화계획, 배점 $40 \%$ )

〈표 3-7〉 농촌생활권 활성화 계획 기본항목 (400점)

\begin{tabular}{|c|c|c|c|}
\hline \multicolumn{2}{|c|}{ 평가항목 } & 세부항목 & 평가내용 \\
\hline \multirow{9}{*}{$\begin{array}{l}\text { 농촌 } \\
\text { 생활권 } \\
\text { 활성화 } \\
\text { 계획 } \\
\text { (300점) }\end{array}$} & \multirow{3}{*}{$\begin{array}{l}\text { 사업추진 } \\
\text { 가능성 } \\
\text { (75) }\end{array}$} & $\begin{array}{l}\text { 사업추진여건 } \\
\text { (15) }\end{array}$ & $\begin{array}{l}\text { · 부지 확보율(확보가 필요한 전체 부지 기준) } \\
\text { - 사업추진 과정에서의 민원 발생 가능성 }\end{array}$ \\
\hline & & $\begin{array}{l}\text { 사업대상지입지 } \\
\text { 적정성 } \\
\text { (30) }\end{array}$ & $\begin{array}{l}\text { · (필수과제) 읍면 소재지 및 배후마을 주민들의 핵심시설 접근성 } \\
\text { - (필수과제) 핵심시설 조성 예정지의 입지 적정성 } \\
\text { - 거점지구 설정의 적절성 및 거점지구 내 적정 대상지 선정 여부 } \\
\text { - (선택과제) 사업대상지 선정의 적정성 }\end{array}$ \\
\hline & & $\begin{array}{c}\text { 사업계획의실행 } \\
\text { 력(30) }\end{array}$ & $\begin{array}{l}\text { - (필수과제) 사업계획에 대한 법적·제도적 제약 유무 및 사업 기간 } \\
\text { 내 사업 완료 가능성 } \\
\text { - 토지이용계획, 관련 인허가 및 행정절차 등 고려 시 사업추진과 } \\
\text { 정에서 예상되는 법적·제도적 문제점 유무 및 사업기간 내 해소 } \\
\text { 가능성(사업지연·실패 우려 유무) } \\
\text { - (선택과제) 사업계획에 대한 법적·제도적 제약 유무 및 사업 기간 } \\
\text { 내 사업 완료 가능성 }\end{array}$ \\
\hline & $\begin{array}{l}\text { 지역의 } \\
\text { 추진 } \\
\text { 의지· } \\
\text { 준비도 } \\
\text { (30) }\end{array}$ & - & $\begin{array}{l}\text { - 각 사업별 전담인력 배치의 적정성 } \\
\text { - 사업 추진체계의 적정성 } \\
\text { - 전담부서, 기초계획지원단(또는 PM단), 중간지원조직, 주민위 } \\
\text { 원회 등 사업 참여주체 구성 여부 및 적정성 } \\
\text { - (필수과제) 지역사회 주도의 서비스 공급.전달을 위해 다양한 지 } \\
\text { 역공동체가 참여하는지 여부 }\end{array}$ \\
\hline & \multirow{4}{*}{$\begin{array}{c}\text { 계획의 } \\
\text { 타당성(13 } \\
5)\end{array}$} & $\begin{array}{l}\text { 농촌공간 전략 } \\
\text { 계획과의 } \\
\text { 연계성·충실성 } \\
\quad \text { (30) }\end{array}$ & $\begin{array}{l}\text { - 활성화계획에 제시된 사업이 농촌공간 전략계획과의 논리적 연계 } \\
\text { 성을 갖추었는지 여부 } \\
\text { - 농촌공간 전략계획 상 생활권 활성화계획을 고려 시 각 사업의 내 } \\
\text { 용의 적정성 } \\
\text { - 농촌재생뉴딜사업 추진을 위한 농촌공간정비계획과 연계 정도 }\end{array}$ \\
\hline & & $\begin{array}{l}\text { 연계사업의 } \\
\text { 적정성(15) }\end{array}$ & $\begin{array}{l}\text { - 농촌협약 대상생활권에 설정된 정책과제 및 세부추진과제를 고려 } \\
\text { 시 제시된 연계사업의 적정성·타당성 }\end{array}$ \\
\hline & & 필수과제(30) & $\begin{array}{l}\text { - 생활권 내 상위·하위거점 및 배후마을 연계구조 고려 시 생활 } \\
\mathrm{SOC} \text { 시설 확충계획의 적정성(필요성·시급성 고려) } \\
\text { - 생활SOC 시설에 대한 투자규모의 적정성 } \\
\text { - 각 사업의 규모·물량 등을 고려 시 지역별·연차별 사업비 투자계 } \\
\text { 획이 적절하게 수립되었는지 } \\
\text { - 비전·발전목표·추진전략 등에 부합하는 방향으로 사업의 목표 및 } \\
\text { 성과지표가 적절하게 설정되었는지 }\end{array}$ \\
\hline & & 선택과제(30) & $\begin{array}{l}\text { - 사업내용 및 투자규모의 적정성 } \\
\text { - 각 사업의 규모물량 등을 고려 시 연차별 사업비 투자계획이 적절 } \\
\text { 하게 수립되었는지 } \\
\text { - 비전·발전목표·추진전략 등에 부합하는 방향으로 사업의 목표 및 } \\
\text { 성과지표가 적절하게 설정되었는지 }\end{array}$ \\
\hline & $\begin{array}{l}\text { 운영 관리 } \\
\text { 계획의 } \\
\text { 적정성. }\end{array}$ & $\begin{array}{l}\text { 통합관리계획의 } \\
\text { 적정성 } \\
\text { (30) }\end{array}$ & $\begin{array}{l}\text { - 사업 통합관리계획의 적절성 } \\
\text { - 사업 기간 내 적기에 복수의 사업이 원만하게 추진될 수 있도록 } \\
\text { 통합관리체계와 계획을 이행 가능한 수준으로 제시하였는지 }\end{array}$ \\
\hline
\end{tabular}




\begin{tabular}{|c|c|c|c|}
\hline \multicolumn{2}{|c|}{ 평가항목 } & \multirow[b]{2}{*}{$\begin{array}{l}\text { 세부항목 } \\
\text { 사후운영계획의 } \\
\text { 적정성·지속가 } \\
\text { 능성 } \\
\text { (30) }\end{array}$} & \multirow[b]{2}{*}{$\begin{array}{l}\text { 평가내용 } \\
\text { - (필수과제) 사업을 통해 조성된 서비스 기능시설의 운영 및 관리 } \\
\text { 계획의 지속가능성 } \\
\text { - 사업을 통해 조성된 H/W 및 S/W에 대한 운영계획의 적정성. } \\
\text { 지속가능성 } \\
\text { - 지역사회 주도의 서비스 공급·전달 지속가능성 } \\
\text { · (선택과제) 사업 완료 후에도 사업의 목적에 부합하며, 지속가능 } \\
\text { 한 운영계획을 제시하였는지 여부 }\end{array}$} \\
\hline & $\begin{array}{l}\text { 지속 } \\
\text { 가능성 } \\
(60)\end{array}$ & & \\
\hline \multirow{10}{*}{$\begin{array}{l}\text { 농촌공간정 } \\
\text { 비계획 } \\
(100)\end{array}$} & \multirow{5}{*}{$\begin{array}{l}\text { 계획의 } \\
\text { 적정성 } \\
(30)\end{array}$} & $\begin{array}{l}\text { 현황 및 } \\
\text { 여건진단 } \\
\text { 적정성 } \\
\text { (5) }\end{array}$ & $\begin{array}{l}\text { - 관련 제도 검토, 기초 조사 결과의 적절성 및 충실성 } \\
\text { - 인근 마을 현황 조사의 충실성 } \\
\text { - 토지이용 현황 및 유해시설 조사의 충실성 }\end{array}$ \\
\hline & & $\begin{array}{l}\text { 의견수렴 } \\
\text { 충실성 및 } \\
\text { 동의정도 (5) }\end{array}$ & $\begin{array}{l}\text { - 관련 부서, 전문가 등 의견 수렴 여부 } \\
\text { - 이해관계자(소유주, 임차인 등) 의견조사 수행 여부 } \\
\text { - 사업에 대한 이해관계자 동의 정도 }\end{array}$ \\
\hline & & $\begin{array}{l}\text { 계획의 연계성 } \\
\quad(10)\end{array}$ & $\begin{array}{l}\text { · 정비계획에 제시된 내용이 농촌공간 전략계획에 제시되고 논리적 } \\
\text { 연계성을 갖추었는지 여부 } \\
\text { - 타 계획과의 연계 수립 여부 및 연계 가능성 }\end{array}$ \\
\hline & & $\begin{array}{l}\text { 목표와 지구 } \\
\text { 선정의 적정성 } \\
\quad(10)\end{array}$ & $\begin{array}{l}\text { · 실현가능한 객관적 사업 목표 제시 여부 } \\
\text { · 대상지구(정비지구 및 이전지구) 선정 적정성 }\end{array}$ \\
\hline & & $\begin{array}{l}\text { 부지활용 방향 } \\
\text { 적정성 }(10)\end{array}$ & $\begin{array}{l}\text { · 존치 부지 활용 방향의 공공성 } \\
\text { · 주변 환경과의 연속성 및 주민 삶의 질 향상 부합 정도 }\end{array}$ \\
\hline & \multirow{2}{*}{$\begin{array}{l}\text { 계획의 } \\
\text { 구체성 } \\
\text { (30) }\end{array}$} & $\begin{array}{l}\text { 토지이용 } \\
\text { 구상의 구체성 } \\
\quad(15)\end{array}$ & $\begin{array}{l}\text { · 향후 예상되는 토지이용 방향의 적정성 } \\
\text { · 유해시설 철거, 개량, 존치 방향의 적절성 } \\
\text { - 세부적인 부지 조성 및 공간 활용 방안의 구체성 }\end{array}$ \\
\hline & & $\begin{array}{l}\text { 기타 관리계획 } \\
\text { 수립 여부 (5) }\end{array}$ & $\begin{array}{l}\text { - 사업과 관련한 환경 정비 및 경관관리 계획 수립 여부 } \\
\text { - 사업 후 대상 지구의 운영 관리계획 수립여부 }\end{array}$ \\
\hline & \multirow{2}{*}{$\begin{array}{c}\text { 투자 및 } \\
\text { 관리 } \\
\text { 운영계회 } \\
\text { 의 실현 } \\
\text { 가능성 } \\
\text { (30) }\end{array}$} & $\begin{array}{l}\text { 투자계획의 } \\
\text { 적절성 (15) }\end{array}$ & $\begin{array}{l}\text { - 사업내용 및 투자규모의 적절성 } \\
\text { · 부지 매입 및 보상 규모 산정 여부 } \\
\text { - 각 사업의 규모물량 등을 고려시 연차별 사업비 투자계획의 적절 } \\
\text { 성 } \\
\text { · 시설 보상 협의 및 주민 설명회 등의 일정을 고려한 실현가능한 } \\
\text { 추진계획 수립 여부 }\end{array}$ \\
\hline & & $\begin{array}{l}\text { 예산 조달 및 } \\
\text { 투자계획의 } \\
\text { 실현 가능성 } \\
\quad \text { (15) }\end{array}$ & $\begin{array}{l}\text { - 재원 조달 계회의 이행가능성 } \\
\text { - 민간 사업자 활용 여부 및 적정성 } \\
\text { (농촌재생뉴딜사업과 연관된 민간 사업이 있는 경우, 적절성 및 } \\
\text { 규모 판단) }\end{array}$ \\
\hline & $\begin{array}{l}\text { 지역의 } \\
\text { 추진 의지 } \\
\text { ·준비도 } \\
\text { (10) }\end{array}$ & - & $\begin{array}{l}\text { · 전담부서, 행정협의회 등 구성 여부 및 적정성 } \\
\text { · 주민협의체, 갈등조정위원회 등 구성 여부 } \\
\text { · 외부 전문가 } \mathrm{MP} \text { (총괄기획가) 위촉 여부 }\end{array}$ \\
\hline
\end{tabular}

자료: 농림축산식품부(2021.2), 2021년 농촌협약 추진계획 
〈표 3-8〉 농촌생활권 활성화 계획 가감점 항목 ( \pm 20 점)

\begin{tabular}{|c|c|}
\hline 평가항목 & 평가내용 \\
\hline $\begin{array}{c}\text { 가점 } \\
(\text { 최대+30) }\end{array}$ & $\begin{array}{l}\text { · 마을만들기사업의 '21년 총사업비 또는 신규지구 예산이 '19년 대비 큰 경우 } \\
\text {, } 20 \text { 년 일반농산어촌개발사업 실집행률이 } 83 \% \text { 이상 } \\
\text { · 선택과제 이행을 위해 제시한 모든 사업의 추진이 } 100 \% \text { 확정된 경우 (사업대상자로 기 } \\
\text { 선정된 경우) } \\
\text { · 광역 또는 기초단위 중간지원조직을 통합 운영 중 }\end{array}$ \\
\hline $\begin{array}{c}\text { 감점 } \\
\text { (최대 - } 30)\end{array}$ & $\begin{array}{l}\text { - 마을만들기사업 '21년 총사업비가 '19년 대비 작은 경우 } \\
\text { - '20년 일반농산어촌개발사업 실집행률이 } 70 \% \text { 이하 } \\
\text { - 평가 안내 사항 준수 여부 } \\
\text {, 증빙자료 구비여부 및 제반서류의 진위성 }\end{array}$ \\
\hline
\end{tabular}

자료: 농림축산식품부(2021.2), 2021년 농촌협약 추진계획

\section{다. 성과평가}

2021년 본격 협약이 체결된 농촌협약은 협약체결 이후 정책과제별 성과 목표와 관리 계획을 활성화 계획에 포함해 계획 이행 상황을 지속 점검·평가할 계획이다. 농림축산식 품부는 성과를 측정·평가할 수 있는 기준 및 가이드라인을 마련하고, 지방자치단체는 계 획 수립 시 성과목표를 설정하도록 하여 중간·최종 평가에서 추진실적과 목표달성도를 점검한다. 가이드라인은 농촌협약의 핵심 정책사업인 일반농산어촌개발사업이 균형발전 특별법에 따른 균형발전사업임을 고려하여 국가균형발전위원회의 균형발전사업 평가기 준을 참고하여 마련할 계획이다. 특히 마을만들기 등 지방으로 이양된 사업예산이 농촌 지역에 적절하게 투입되었는가를 평가에 포함할 계획이다.

3년차에 예정인 중간평가는 이행실적, 실집행률 등을 평가하고 그 결과 사업비, 내용, 기간 등을 조정한다. 5년차에 예정인 최종평가는 성과목표 달성여부 등을 평가하고 결과 는 차기 협약 시 반영한다. 또한 중간·최종 평가 결과에 따른 인센티브(예산증액, 평가가 점) 및 패널티(예산감액, 협약조정, 신규협약 감점)를 제공할 계획이다. 


\section{제2절 지역자율형 사회서비스투자사업(복지부)}

\section{1. 사례개요}

\section{가. 지역자율형 사회서비스투자사업 개념}

지역자율형 사회서비스 투자사업은 사회서비스 바우처사업으로 산모신생아 건강관리 지원사업, 가사간병 방문지원사업, 지역사회서비스 투자사업 등 3개 내역사업을 통합하 고 지방자치단체 수요에 따라 예산을 자율 편성하도록 하는 포괄보조 사업이다. 지방자 치단체가 돌봄, 재활, 상담 등 지역 수요에 맞는 맞춤형 사회서비스를 개발하여 사업 기 획 및 집행을 탄력적으로 진행할 수 있도록 포괄보조방식의 재정투자를 국가균형발전특 별회계로부터 예산배정을 받고 있다.

\section{나. 추진배경}

2000년대 중반 이후 신사회적 위험의 확대로 기존 중앙정부 주도의 잔여적 복지서비 스 전달 체계는 지역주민의 다양한 서비스 욕구 대응에 제한적일 수밖에 없는 바, 서비 스 공급의 다변화를 통한 일자리 창출과 서비스 확충을 동시에 도모하기 위해 사회서비 스 정책을 추진하였다. 사회서비스가 국민의 삶의 질 향상을 궁극의 목적으로 하고 있다 는 점에서 기존 복지서비스와 명백하게 구분되는 정책영역은 아니지만, 이용자 중심의 전자바우처 제도를 적용한 서비스 전달 방식의 변화를 모색하였다. 그리고 정책 집행의 거버넌스 단위를 중앙정부에서 지방자치단체로 이동하여 민간 공급주체의 유입을 도모 하는 등 서비스 공급기반을 다변화시키기 위한 시도는 과거 복지정책의 집행 과정에서 찾아보기 어려운 새로운 시도였다. 뿐만 아니라 기존 복지체계 내에서 다루어지지 못했 던 일상화되고 개별화된 욕구(personalized needs)에 대해 보다 민감하게 대응할 수 있도록 서비스 내용을 다양화시키고, 새로운 서비스 유형들이 제도화 되는 계기를 마련 
하고 있다는 점 등은 분명 차별화된 정책시도로 평가할 수 있다.

지난 2006년도 사회서비스 일자리 창출전략의 일환으로 출발한 사회서비스 정책의 대표 사업으로 지역자율형 사회서비스투자사업은 지역사회서비스혁신사업으로부터 출 발하여 지역사회와 지방자치단체가 주체가 되어 지역특성이 반영된 사회서비스 욕구를 파악하고, 이에 따르는 공급모형과 공급기관을 발굴·육성하여 전자바우처제도를 통한 서비스 제공 방식을 도입하였다. 그간 경험한 복지서비스 전달과정의 대부분이 중앙정부 의 사업기획에 따르는 지방정부의 집행력을 전제로 설계된 점과 분명하게 구분된다. 지 역단위의 서비스 욕구에 대응하기 위한 참신한 서비스 전달방식으로서 기존의 수직적 지휘·감독 관계의 중앙-지방정부 간의 복지 거버넌스를 수평적 협력체계로 전화시키고, 지방자치단체의 적극적인 서비스 발굴과 사업관리 노력을 견인하는 촉매 역할을 수행하 도록 요구하고 있다.

지역사회서비스혁신사업은 2009년 지역사회서비스 투자사업으로 사업명을 변경하 고, 지난 2013년에는 포괄보조방식의 지역자율형 사회서비스 투자사업으로 사업명을 전환하였다. 기존의 지역사회서비스 투자사업과 산모신생아건강관리사지원사업 및 가사 간병방문관리사지원사업을 통합하여 포괄보조사업으로 전환한 것이다. 포괄보조방식의 도입으로 중앙정부의 예산편성 기준에 따라 지역사회의 특성과 서비스 수급상황을 고려 하여 지방자치단체에서 사업별 예산을 자율적으로 편성할 수 있게 되었다.

[그림 3-3] 지역자율형 사회서비스 투자사업 추진배경

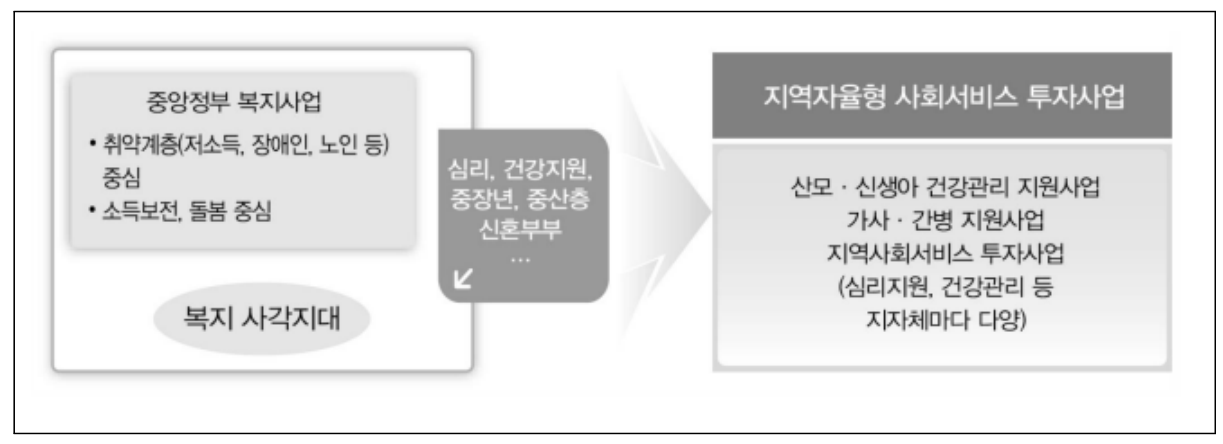

자료: 보건복지부(2021), 2021년도 지역사회서비스 투자사업 안내 


\section{다. 현황}

지역자율형 사회서비스 투자사업은 국가균형발전특별회계 지역지원계정으로 기획재 정부가 정한 기본한도 내에서 지방자치단체별 재원총량을 설정하고, 시·도 사업별 수요 에 따라 구체적인 사회서비스 프로그램의 개발과 운영이 결정된다. 2021년 기준 지역자 율형 사회서비스 투자사업 예산은 국비 3,253억원이다(지방자치단체 경상보조 서울 $50 \%$, 서울이외 사도 $70 \%$, 성장촉진지역 $80 \%$ ).

2019년 기준 지역사회서비스투자사업, 가사간병방문지원사업, 산모신생아건강관리 사업은 각각 제공기관 4,657개, 433 개, 837 개, 제공인력 22,156명, 5,392명, 17,024 명, 이용자 256,111 명, 8,775 명, 97,905명 등이 참여하고 있다.

〈표 3-9〉 지역자율형 사회서비스 투자사업 제공 및 이용자 규모(2019년)

(단위: 개, 명)

\begin{tabular}{c|r|r|r|r|r|r|r|r|r}
\hline \multirow{2}{*}{ 구분 } & \multicolumn{2}{|c|}{ 지역사회서비스투자사업 } & \multicolumn{3}{|c|}{ 가사.간병 방문지원사업 } & \multicolumn{3}{|c}{ 산모신생아 건강관리사업 } \\
\cline { 2 - 10 } & 제공기관 & 제공인력 & 이용자 & 제공기관 & 제공인력 & 이용자 & 제공기관 & 제공인력 & 이용자 \\
\hline 서울 & 427 & 1,921 & 13,723 & 55 & 547 & 678 & 202 & 3,912 & 22,245 \\
\hline 부산 & 489 & 1,962 & 24,680 & 28 & 312 & 774 & 31 & 806 & 4,137 \\
\hline 대구 & 302 & 1,356 & 14,231 & 14 & 186 & 493 & 18 & 875 & 5,524 \\
\hline 인천 & 267 & 1,583 & 21,685 & 16 & 242 & 433 & 46 & 934 & 5,336 \\
\hline 대전 & 184 & 1,133 & 14,599 & 12 & 153 & 213 & 20 & 524 & 2,321 \\
\hline 광주 & 222 & 1,118 & 12,658 & 17 & 201 & 468 & 18 & 471 & 2,452 \\
\hline 울산 & 130 & 544 & 5,963 & 6 & 104 & 205 & 14 & 472 & 2,779 \\
\hline 경기 & 1,013 & 5,056 & 41,676 & 56 & 786 & 986 & 267 & 4,043 & 21,140 \\
\hline 강원 & 186 & 772 & 10,000 & 23 & 308 & 459 & 24 & 395 & 2,605 \\
\hline 충북 & 156 & 740 & 9,009 & 16 & 140 & 246 & 17 & 438 & 3,176 \\
\hline 충남 & 208 & 893 & 12,558 & 26 & 305 & 362 & 40 & 862 & 5,421 \\
\hline 경북 & 227 & 1,017 & 14,479 & 43 & 432 & 601 & 33 & 864 & 4,416 \\
\hline 경남 & 335 & 1,122 & 9,861 & 41 & 516 & 669 & 47 & 861 & 5,848 \\
\hline 전남 & 124 & 868 & 18,836 & 44 & 449 & 785 & 21 & 533 & 4,036 \\
\hline 전북 & 245 & 1,250 & 19,204 & 29 & 635 & 1,278 & 14 & 532 & 3,332 \\
\hline 제주 & 107 & 677 & 12,013 & 5 & 57 & 105 & 5 & 161 & 1,039 \\
\hline 세종 & 35 & 144 & 936 & 2 & 19 & 20 & 20 & 341 & 2,098 \\
\hline 합계 & 4,657 & 22,156 & 256,111 & 433 & 5,392 & 8,775 & 837 & 17,024 & 97,905 \\
\hline
\end{tabular}

자료: 보건복지부 내부자료 


\section{2. 운영방식}

\section{가. 추진절차}

지역자율형 사회서비스투자사업은 지역사회 단위로 지역주민의 서비스 수요와 서비 스 공급자원을 고려하여 지방자치단체가 직접 서비스를 개발하고 제공할 수 있는 지원 체계의 구축을 기본 모형으로 사업을 설계하고 있다. 지방자치단체는 선정된 이용자에게 바우처를 지원하고, 이용자는 서비스를 해당 공급자에게 바우처를 사용하여 이용료를 결 제하는 방식으로 사업을 전개한다.

[그림 3-4] 지역사회서비스투자사업의 기본 전개

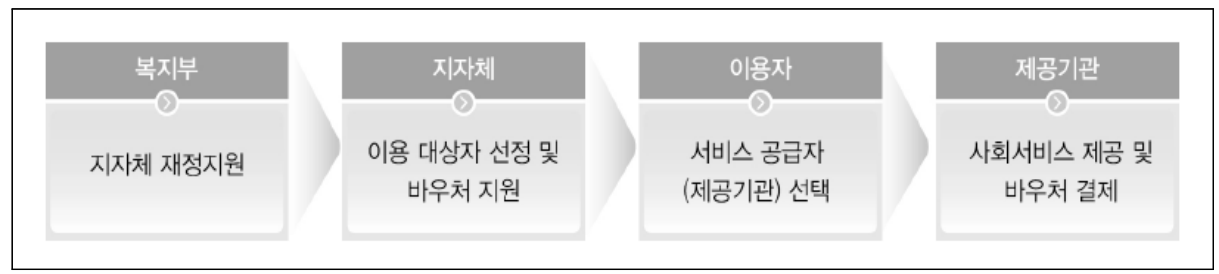

자료: 보건복지부(2021), 2021년도 지역사회서비스투자사업 안내,

당초 국고지원 방식의 사회서비스 재정지원방식을 2013년부터는 포괄보조(Block Grant)로 전환하여 지방자치단체의 사업 기획력을 강화하는 동시에 정책 집행의 자율성 과 책임성을 부여하는 것이다. 2019년 예산안부터 국가균형발전특별회계 지역자율계정 에서 지역지원계정으로 전환(2018. 8월)되면서 중앙부처가 예산편성의 주체가 되고, 지 방자치단체는 사업기획과 운영의 자율성과 책임성이 부여되었다.

〈표 3-10〉지역자율형 사회서비스투자사업 예산의 편성 절차

(1) 1단계: 중앙정부(4월)

- 기획재정부가 보건복지부에 국가균형발전특별회계 사업의 기본한도 통보

(2) 2 단계: 시·도(4 5월)

- 시·도는 사업별 수요를 파악하여 복지부 및 국가균형발전위원회에 예산신청서를 제출(4월 27일까지)

- 복지부는 지자체의 예산신청서 및 국가균형발전위원회의 의견을 기초로 작성한 예산요구서를 5월 25일 까지 기재부 제출

(3) 3단계: 기획재정부(6 8월)

- 기재부는 예산요구의 적정성 검토, 사업내역 조정

(4) 4단계: 기획재정부(8 9월)

- 평가에 의한 시·도별 인센티브와 추가한도 등을 검토하여 정부안 확정 및 국회 제출

(5) 5 단계: 국회(12월)

- 차년도 지역자율형 사회서비스 투자사업 예산 확정 


\section{나. 사업내용}

포괄보조 방식으로 수행되는 지역자율형 사회서비스투자사업은 3개 내역사업(지역사 회서비스투자사업, 산모신생아건강관리서비스, 가사간병서비스)으로 구성되는데 각 내 역사업은 고유 사업 추진체계와 운영범위를 구축하고 있다.

[그림 3-5] 지역자율형 사회서비스 투자사업 구조

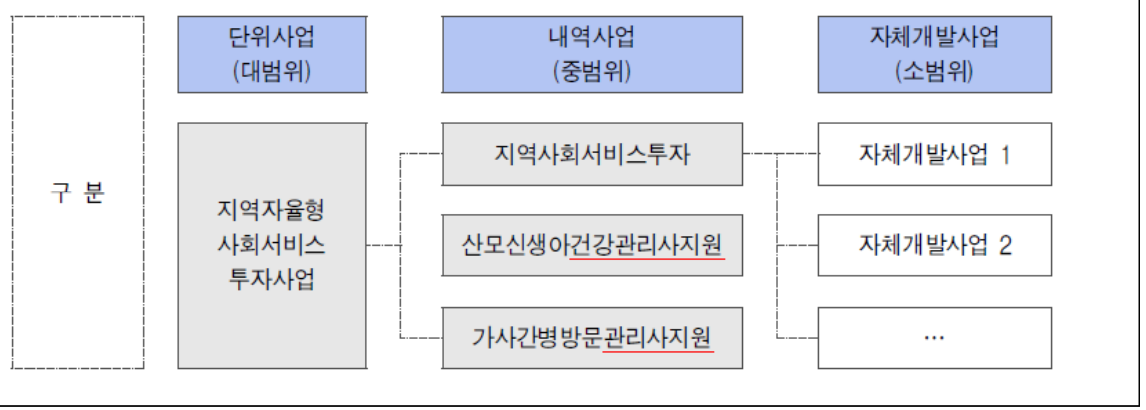

자료: 보건복지부(2014), 지역자율형사회서비스 투자사업 안내

〈표 3-11〉 지역자율형 사회서비스 투자사업 내역사업별 사업내용

\begin{tabular}{|c|c|c|c|}
\hline & 지역사회서비스투자사업 & 산모신생아 건강관리지원사업 & 가사-간병 방문 지원사업 \\
\hline $\begin{array}{l}\text { 추진 } \\
\text { 근거 }\end{array}$ & $\begin{array}{l}\ulcorner\text { 사회서비스 이용 및 이용권 관리 } \\
\text { 에 관한 법률」제4조, 제 } 5 \text { 조 }\end{array}$ & $\begin{array}{l}\ulcorner\text { 「사회서비스 이용 및 이용권 관리 } \\
\text { 에 관한 법률」, 「저출산·고령사회 } \\
\text { 기본법」제8조, 제10조, 「모자보 } \\
\text { 건법」제15조의 } 18\end{array}$ & $\begin{array}{l}\ulcorner\text { 사회서비스 이용 및 이용권 관리 } \\
\text { 에 관한 법률」, 「사회복지사업법」 } \\
\text { 제33조의 } 7 \text { (서비스의 제공방법) }\end{array}$ \\
\hline $\begin{array}{l}\text { 사업 } \\
\text { 목적 }\end{array}$ & $\begin{array}{l}\text { 중앙정부가 전국을 대상으로 일괄 } \\
\text { 실시하는 국가 주도형 서비스 제 } \\
\text { 공방식에서 탈피하여, 지자체가 } \\
\text { 지역 특성 및 주민 수요에 맞는 사 } \\
\text { 회서비스를 발굴·기획 }\end{array}$ & $\begin{array}{l}\text { 출산 가정에 산모·신생아 관리사 } \\
\text { 를 통한 가정방문 서비스를 지원 } \\
\text { 하여 산모와 신생아 건강관리 및 } \\
\text { 출산가정의 경제적 부담 완화 }\end{array}$ & $\begin{array}{l}\text { 일상생활과 사회활동이 어려운 저 } \\
\text { 소득층을 위한 가사·간병서비스를 } \\
\text { 지원함으로써 취약계층의 생활 안 } \\
\text { 정을 도모하고 가사.간병 방문 제 } \\
\text { 공인력의 사회적 일자리 창출 }\end{array}$ \\
\hline
\end{tabular}

보건복지부에서는 프로그램의 특성과 제공인력 및 제공조직 등에 대한 포괄적인 지침 을 설정하여 기본적으로 사회서비스 정책의 큰 틀 속에서 개별 사업이 운영될 수 있게 유도한다. 정기적으로 지방자치단체에 대한 사업평가를 통해 지방자치단체별 재원총량 을 조정하고 전국 표준적으로 운영할 필요가 있는 개별 사업은 지정사업으로 전환하여 소관 담당부서를 지정하거나(예, 발달장애아동 언어치료 등), 사업운영 지침의 구체성을 강화하여 많은 지방자치단체의 참여를 유도하고 있다. 


\section{1) 지역사회서비스투자사업}

지역사회서비스투자사업은 중앙정부가 전국을 대상으로 일괄 실시하는 국가 주도형 서비스 제공방식에서 탈피하여, 지방자치단체가 지역 특성 및 주민 수요에 맞는 사회서 비스를 발굴·기획하는 사업이다. 사회서비스 이용권(전자바우처)을 활용한 수요자 중 심 서비스이고, 사업기획·운영 상 지역의 자율성과 책임성을 강조하고 있다. 지역사회 서비스 투자사업 기본구조는 다음과 같다.

〈표 3-12〉 지역사회서비스투자사업 기본구조

\begin{tabular}{|c|c|}
\hline 구분 & 내용 \\
\hline 제공방식 & $\begin{array}{l}\text { 사회서비스 전자바우처 활용 } \\
\text { - 이용자 또는 제공자에게 정부지원금을 직접 주는 현금보조 또는 현물보조가 아니라 이 } \\
\text { 용자가 서비스 제공에 대한 대가를 전자바우처를 통해 지불하는 방식 }\end{array}$ \\
\hline 서비스 개발 & $\begin{array}{l}\text { 지역에서 자율적으로 기획 및 발굴 } \\
\text { - 여타 지자체 보조사업과 달리 시·도 또는 시·군·구에서 지역의 수요와 공급 현황을 } \\
\text { 파악하여 지역개발 사회서비스를 스스로 기획·발굴·집행·평가 }\end{array}$ \\
\hline 이용자 선정 & $\begin{array}{l}\text { 지역의 예산 현황 및 수요에 적합하게 우선순위를 정하여 선정 } \\
\text { - 중앙정부는 이용 대상자의 소득기준 상한만 결정하고, 서비스별 이용 대상자 선정 기준 } \\
\text { 을 예산 집행 현황 및 지역개발 서비스 특성을 고려하여 지자체 책임하에 자율적으로 } \\
\text { 결정 }\end{array}$ \\
\hline 서비스 제공자 & $\begin{array}{l}\text { 제공기관 등록제 시행 } \\
\text { - 기존 시설 위주의 공급자 지원방식이 아니라 수요자 지원 방식으로 사회서비스 등록기 } \\
\text { 준에 적합한 제공자는 제공기관 등록을 통해 자유롭게 서비스를 제공할 수 있으며, 다 } \\
\text { 수의 제공기관을 이용자가 선정하여 시장을 활용하는 구조 }\end{array}$ \\
\hline 서비스 가격 체계 & $\begin{array}{l}\text { 이용자 본인부담금 } \\
\text { - 이용자의 서비스 비용을 전액 정부에서 지원하는 것이 아니라, 서비스 이용에 따른 본 } \\
\text { 인부담금이 존재하여 사회서비스 시장화 유도 }\end{array}$ \\
\hline 지원조직 & $\begin{array}{l}\text { 지역사회서비스 지원단 } \\
\text { - 시·도별로 지역사회서비스 지원단을 선정하여 사회서비스 종사자 교육과 훈련, 제공 } \\
\text { 기관 컨설팅, 지역맞춤형 사회서비스 기획·발굴, 지역사회서비스 홍보, 제공기관 현장 } \\
\text { 점검 등 지원 }\end{array}$ \\
\hline
\end{tabular}

자료: 보건복지부(2021), 2021년도 지역사회서비스 투자사업 안내 
〈표 3-13〉 지역사회서비스투자사업 추진체계 및 기능

\begin{tabular}{|c|c|}
\hline 추진주체 & 기능 \\
\hline 보건복지부 & $\begin{array}{l}\text { - 사업 기본계획 수립, 지침 작성 총괄 } \\
\text { - 시·도 성과평가 추진 총괄 } \\
\text { - 시·도 서비스 심사 및 승인·감독·평가 } \\
\text { - 전자바우처시스템 구축 및 관리 }\end{array}$ \\
\hline 한국사회보장정보원 & $\begin{array}{l}\text { - 시·군·구 예탁금 관리 } \\
\text { - 바우처 비용지급 및 정산 } \\
\text { - 사업 모니터링 실시 및 통계 관리 } \\
\text { - 지역사회서비스투자사업 품질관리(평가 등) }\end{array}$ \\
\hline 시·도 & $\begin{array}{l}\text { - 지역사회서비스 투자사업 시·도 총괄 관리 } \\
\text { - 지역사회서비스투자사업 서비스 별 예산조정 및 집행관리 } \\
\text { - 시·도 서비스 기획 및 발굴 } \\
\text { - 시·도별 지역사회서비스투자사업 안내 지침 수립 } \\
\text { - 시·군·구 서비스 심사 및 승인·감독·평가 } \\
\text { - 시·도 사회서비스 심의위원회 운영 } \\
\text { - 시·도 성과관리 } \\
\text { - 시·군·구 자체평가체계 구축 및 실시 } \\
\text { - 시·도 내 서비스 제공기관 현장점검 총괄 }\end{array}$ \\
\hline $\begin{array}{c}\text { 지역사회서비스 중앙지원단 } \\
\text { (한국보건복지인력개발원) }\end{array}$ & $\begin{array}{l}\text { - 지역사회서비스지원단 총괄·지원 } \\
\text { - 사회서비스 관련 교육 및 전문인재 양성 } \\
\text { - 사회서비스 컨설팅 지원 } \\
\text { - 사회서비스발전을 위한 조사·연구·개발 } \\
\text { - 지역 간 사회서비스사업 연계·협력체계 구축 } \\
\text { - 사회서비스 인식개선 홍보 }\end{array}$ \\
\hline 지역사회서비스 지원단 & $\begin{array}{l}\text { - 지역사회서비스 제공인력 교육 및 관리 } \\
\text { - 사회서비스 제공기관 컨설팅 } \\
\text { - 지역사회서비스 발굴·기획 지원 } \\
\text { - 민·관 네트워크 구축 } \\
\text { - 제공기관 현장점검 지원 } \\
\text { - 지역사회서비스 정보 제공 및 홍보 지원 }\end{array}$ \\
\hline 시·군·구 & $\begin{array}{l}\text { - 시·군·구 지역사회서비스 관리 및 시행 } \\
\text { - 지역사회서비스 예산집행 분석 및 예탁금 집행 } \\
\text { - 서비스 이용자 선정 및 관리(중도포기자, 미이용자, 대기자 관리, 본인부담금 } \\
\text { 장기미납자 관리 등) } \\
\text { - 지역사회서비스 제공기관 등록·관리 } \\
\text { - 지역개발 서비스 홍보 } \\
\text { - 서비스 제공기관 지도·감독 }\end{array}$ \\
\hline
\end{tabular}

자료: 보건복지부(2021), 2021년도 지역사회서비스 투자사업 안내 


\section{2) 산모신생아 건강관리지원사업}

산모신생아 건강관리지원사업은 출산 가정에 산모·신생아 관리사를 통한 가정방문 서 비스를 지원하여 산모와 신생아 건강관리 및 출산가정의 경제적 부담 완화하고자 바우 처를 지원하는 사업이다. 산모 또는 배우자가 생계·의료·주거·교육급여 수급자 또는 차상위 계층에 해당하는 출산가정을 대상으로 한다. 산모 및 배우자 등 해당가구의 건강보험료 본인 부담금 합산액이 기준중위소득 $120 \%$ 이하 금액에 해당하는 출산가정을 대상으로 하되, 시·도 별로 예산의 범위 내에서 별도의 소득기준을 정할 수 있다. 산모신생아 건강관리지원사업 기본구조는 다음과 같다.

〈표 3-14〉 산모신생아 건강관리지원사업 기본구조

\begin{tabular}{|c|c|}
\hline 구분 & 내용 \\
\hline 지원 대상 & $\begin{array}{l}\text { 국내에 주민등록 또는 외국인 등록을 둔 출산 가정 } \\
\text { * 단, 부부 모두가 외국인인 경우 각 국내 체류자격 비자(사증) 종류가 F-2(거주), F-5 } \\
\text { (영주), F-6(결혼이민)인 경우에 한함 } \\
\text { - 산모 또는 배우자가 생계·의료·주거·교육급여 수급자 또는 차상위계층*에 해당하는 출 } \\
\text { 산가정(차상위본인부담경감, 차상위자활, 차상위장애인, 차상위자격확인) } \\
\text { - 산모 및 배우자 등 해당가구의 건강보험료 본인부담듬 합산액이 기준중위소득 } 120 \% \\
\text { 이하 금액에 해당하는 출산가정 } \\
\text { * 임신 } 16 \text { 주 이후 발생한 유산·사산의 경우도 지원대상에 포함 } \\
\text { - 소득 기준을 초과하더라도 지역자율형 사회서비스 투자사업 예산범위 내에서 광역 시· } \\
\text { 도지사가 별도 소득기준을 정하여 승인한 아래 출산 가정(또는 산모) }\end{array}$ \\
\hline 지원 내용 & $\begin{array}{l}\text { - 산모건강관리(유방관리, 체조지원 등), 신생아 건강관리(목욕, 수유지원 등), 산모 식사 } \\
\text { 준비, 산모·신생아 세탁물 관리 및 청소 등 } \\
\text { - 산모·신생아 외 다른 가족 돌봄이나 일반 가사활동 영역은 표준 서비스에 포함되지 않는 } \\
\text { 부가서비스이므로 원하는 경우 별도로 추가 구매 필요 }\end{array}$ \\
\hline 서비스 지원 기간 & $\begin{array}{l}\text { - 단태아 5 20일, 쌍태아 10 20일, 삼태아 이상 15 25일 } \\
\text { - 태아 유형, 출산 순위, 서비스기간 선택(표준형·단축형·연장형) 등에 따라 바우처 지원 } \\
\text { 기간 차등화하되, 바우처 유효기간은 원칙적으로 출산일로부터 } 60 \text { 일까지임 }\end{array}$ \\
\hline 서비스 비용 & $\begin{array}{l}\text { 보건복지부가 정한 가격 범위 내에서 제공기관이 자율 책정 } \\
\text { - 정부지원금: 태아유형, 출산순위, 소득수준, 이용자 선택(단축·표준·연장)에 따라 차등 지원 } \\
\text { - 본인부담금: 서비스가격에서 정부지원금을 뺀 차액을 자기 부담 }\end{array}$ \\
\hline 서비스 제공자 & $\begin{array}{l}\text { - 제공기관: 제공 서비스 이용 및 이용권 관리에 관한 법률」 제16조에 따라 등록한 제공기관 } \\
\text { - 제공인력: 동법 시행규칙에 따라 보건복지부장관이 고시한 「산모·신생아 방문서비스 제공인력 } \\
\text { 교육과정」을 수료한 사람 } \\
\text { (산규자 과정) 총 60시간(이론 24시간, 실기 36시간) } \\
\text { (경력자 과정) 총 40시간(이론 12시간, 실기 28시간) }\end{array}$ \\
\hline
\end{tabular}

자료: 보건복지부(2021), 2021 산모·신생아 건강관리 지원사업 안내 
〈표 3-15〉 산모신생아 건강관리지원사업 추진체계 및 기능

\begin{tabular}{|c|c|c|}
\hline \multicolumn{2}{|c|}{ 추진주체 } & 기능 \\
\hline \multirow{2}{*}{$\begin{array}{c}\text { 보건복지부 } \\
\text { (사회서비스정책관) }\end{array}$} & 사회서비스사업과 & $\begin{array}{l}\text { - 기본계획 수립, 지침 작성 등 사업 총괄 } \\
\text { - 사업 평가 및 지도·감독 }\end{array}$ \\
\hline & 사회서비스정책과 & $\begin{array}{l}\text { - 바우처 운영계획 수립, 전자바우처 시스템 관리 } \\
\text { - 「사회서비스이용 및 이용권 관리에 관한 법률」 제·개정 및 } \\
\text { 해석(사회서비스 제공자의 등록 및 관리 등) }\end{array}$ \\
\hline \multirow{3}{*}{ 사회보장정보원 } & 개별자격정보부 & - 사회서비스이용 신청(행복e음) \\
\hline & 사회서비스보육본부 & $\begin{array}{l}\text { - 시·군·구 예탁금 관리 } \\
\text { - 국민행복카드 발급 관리 } \\
\text { - 바우처 비용 및 교육비 지급 및 정산 } \\
\text { - 바우처 시스템 관리·운영 및 통계관리 } \\
\text { - 서비스 모니터링 및 사후관리 }\end{array}$ \\
\hline & 시설사회서비스평부 & - 산모신생아건강관리지원사업 평가 등 품질관리 \\
\hline 시·도 & $\begin{array}{c}\text { 보건정책과 등 사업 } \\
\text { 담당부서 }\end{array}$ & $\begin{array}{l}\text { - 사업비 예산 교부 및 조정 } \\
\text { - 제공인력 양성 교육기관 지정 } \\
\text { - 시·군·구 사업 관리 감독 } \\
\text { - 서비스 제공기관 현장점검 }\end{array}$ \\
\hline 시·군·구 & 보건소 & $\begin{array}{l}\text { - 서비스 제공기관 등록 } \\
\text { - 사업비 예산 예탁 및 집행상황 관리 } \\
\text { - 지원대상자 신청 접수 및 선정 } \\
\text { - 제공인력 교육비 및 교통지원금 청구 } \\
\text { - 서비스 제공기관 지도·감독 및 현장점검 }\end{array}$ \\
\hline $\begin{array}{c}\text { 중앙사회서비스 } \\
\text { 지원단 }\end{array}$ & 한국보건복지인력개발원 & $\begin{array}{l}\text { - 사회서비스 발전을 위한 조사·연구·개발 } \\
\text { - 지역 간 사회서비스사업 연계·협력체계 구축 } \\
\text { - 사회서비스 관련 교육 및 홍보 } \\
\text { - 지역사회서비스지원기관에 대한 지원 }\end{array}$ \\
\hline $\begin{array}{c}\text { 지역사회서비스 } \\
\text { 지원단 }\end{array}$ & $\begin{array}{c}\text { 시·도 } \\
\text { 지역사회서비스지원단 }\end{array}$ & $\begin{array}{l}\text { - 제공인력 역량강화 } \\
\text { - 서비스 제공기관 대상 컨설팅 } \\
\text { - 서비스 제공기관 현장점검 지원 } \\
\text { - 서비스 홍보 등 지원체계 구축 }\end{array}$ \\
\hline 서비스제공기관 & 기관 담당자 & $\begin{array}{l}\text { - 서비스 제공인력 모집 및 교육, 노무관리 } \\
\text { - 서비스 제공 및 모니터링 } \\
\text { - 서비스 비용 청구 및 제공인력 급여 지급 } \\
\text { - 바우처 시스템 활용 }\end{array}$ \\
\hline 지정교육기관 & 기관 담당자 & $\begin{array}{l}\text { - 교육생 모집, 교육 계획수립 및 운영 } \\
\text { - 수료생 관리 및 취업 연계 } \\
\text { - 바우처 시스템 활용 }\end{array}$ \\
\hline
\end{tabular}

자료: 보건복지부(2021), 2021 산모·신생아 건강관리 지원사업 안내 


\section{3) 가사·간병 방문 지원사업}

가사-간병 방문 지원사업은 일상생활과 사회활동이 어려운 저소득층을 위한 가사·간병 서비스를 지원함으로써 취약계층의 생활 안정을 도모하고 가사·간병 방문 제공인력의 사회적 일자리 창출을 위해 바우처를 지원하는 사업이다. 만65세 미만의 생계·의료·주거. 교육급여 수급자, 다음에 해당하는 사람으로 가사.간병 서비스가 필요한 자를 대상으로 한다.

〈표 3-16〉 가사·간병 방문 지원사업 기본구조

\begin{tabular}{|c|c|}
\hline 구분 & 내용 \\
\hline 지원 대상 & $\begin{array}{l}\text { 만65세 미만의 생계·의료·주거·교육급여 수급자, 다음에 해당하는 사람으로 가사·간병 } \\
\text { 서비스가 필요한 자 } \\
\text { - 장애정도가 심한 장애인 } \\
\text { - 6개월 이상 치료를 필요로 하는 중증질환자 } \\
\text { - 희귀난치성 질환자 } \\
\text { - 소년소녀가정, 조손가정, 한부모가정(법정보호세대) } \\
\text { - 만 65세미만의 의료급여수급자 중 장기입원 사례관리 퇴원자 } \\
\text { - 기타 위에 준하는 경우로 시·군·구청장이 가사·간병 서비스가 필요하다고 별도로 인정 } \\
\text { 한 자 (부상으로 인한 장기치료자 등) } \\
\quad ※ \text { 서비스 지원기간은 } 1 \text { 년이 원칙이나, 소득기준, 건강 및 욕구 상태 등을 확인하여 } \\
\quad \text { 지속 지원 필요성이 높은 경우 } 1 \text { 년 단위로 연장 가능 }\end{array}$ \\
\hline 지원 내용 & $\begin{array}{l}\text { 신체수발 지원: 목욕, 대소변, 옷 갈아입히기, 세면, 식사 등 보조 } \\
\text { 간병지원: 체위변경, 간단한 재활운동 보조 등 } \\
\text { 가사지원: 쇼핑, 청소, 식사 준비, 양육 보조 등 } \\
\text { 일상생활 지원: 외출 동행, 말벗, 생활 상담 등 }\end{array}$ \\
\hline 서비스 지원 기간 & $\begin{array}{l}\text { - 지원기간: 바우처 자격 결정일로부터 } 1 \text { 년 } \\
\text { ※ 단, 재판정 절차를 통해 } 1 \text { 년 단위로 연장 가능, C형은 } 6 \text { 개월 지원 연장불가 } \\
\text { - 지원시간: 월 } 24 \text { 시간 또는 } 27 \text { 시간(C형은 40시간) }\end{array}$ \\
\hline 서비스 비용 & $\begin{array}{l}\text { 월 } 355,200 \text { 원(24시간), 월 } 399,600 \text { 원(27시간), 월 } 592,000 \text { 원(40시간) } \\
\text { - 정부지원금: 소득수준 및 이용시간에 따라 차등 지원(보건복지부, 2021) } \\
\text { - 본인부담금: 서비스 가격에서 정부지원금을 뺀 차액 부담(보건복지부, 2021) }\end{array}$ \\
\hline 서비스 제공자 & $\begin{array}{l}\text { - 제공기관: 「사회서비스 이용 및 이용권 관리에 관한 법률」제16조 제1항 및 같은 법 } \\
\text { 시행규칙 제9조 [별표1]에 따라 등록한 제공기관 } \\
\text { - 제공인력: 서비스 제공인력은 「노인복지법」에 따른 요양보호사 }\end{array}$ \\
\hline
\end{tabular}

자료: 보건복지부(2021), 2021 가사·간병 방문 지원사업 안내 
〈표 3-17〉 가사.간병 방문 지원사업 추진체계 및 기능

\begin{tabular}{|c|c|c|c|}
\hline \multicolumn{3}{|c|}{ 추 진 주 체 } & 기 능 \\
\hline \multirow[b]{2}{*}{ 보건복지부 } & \multirow{2}{*}{$\begin{array}{c}\text { 사회서비스 } \\
\text { 정책관 }\end{array}$} & $\begin{array}{l}\text { 사회서비스 } \\
\text { 사업과 }\end{array}$ & $\begin{array}{l}\text { - 기본계획 수립, 지침 작성 등 사업 총괄 } \\
\text { - 사업 평가 및 지도·감독 }\end{array}$ \\
\hline & & $\begin{array}{c}\text { 사회서비스 } \\
\text { 정책과 }\end{array}$ & $\begin{array}{l}\text { - 바우처 운영계획 수립 및 관리 } \\
\text { - 전자바우처 시스템 구축 및 관리 } \\
\text { - 사회서비스 제공자의 등록 및 관리 }\end{array}$ \\
\hline \multirow{4}{*}{$\begin{array}{l}\text { 한국 } \\
\text { 사회보장 } \\
\text { 정보원 }\end{array}$} & \multicolumn{2}{|c|}{ 개별자격정보부 } & - 사회서비스이용 신청(행복e음) \\
\hline & \multicolumn{2}{|c|}{ 사회서비스 보육기획부 } & $\begin{array}{l}\text { - 시·군·구 예탁금 관리 } \\
\text { - 국민행복카드 발급 관리 } \\
\text { - 바우처 비용 및 교통비 지급 및 정산 } \\
\text { - 바우처 시스템 관리·운영 및 통계 관리 }\end{array}$ \\
\hline & \multicolumn{2}{|c|}{ 서비스모니터링부 } & - 서비스 모니터링 및 사후관리 \\
\hline & \multicolumn{2}{|c|}{ 시설사회서비스평가부 } & - 가사·간병방문지원사업 평가 등 품질관리 \\
\hline 시·도 & \multicolumn{2}{|c|}{ 사업 담당부서 } & $\begin{array}{l}\text { - 사업비 예산 교부 및 조정 } \\
\text { - 시·군·구 사업 관리 감독 } \\
\text { - 서비스 제공기관 현장점검 }\end{array}$ \\
\hline \multirow[t]{2}{*}{ 시·군·구 } & \multicolumn{2}{|c|}{ 사업 담당부서 } & $\begin{array}{l}\text { - 서비스 제공기관 등록 } \\
\text { - 사업비 예산 예탁 및 집행상황 관리 } \\
\text { - 지원대상자 신청 접수 및 선정 } \\
\text { - 제공인력 교통지원금 청구 } \\
\text { - 서비스 제공기관 지도·감독 및 현장점검 }\end{array}$ \\
\hline & \multicolumn{2}{|c|}{ 읍·면·동 공무원 } & - 서비스 신청 접수 \\
\hline $\begin{array}{l}\text { 중앙 } \\
\text { 사회서비스 } \\
\text { 지원단 }\end{array}$ & \multicolumn{2}{|c|}{ 한국보건복지인력개발원 } & $\begin{array}{l}\text { - 사회서비스 발전을 위한 조사·연구·개발 } \\
\text { - 지역 간 사회서비스사업 연계·협력체계 구축 } \\
\text { - 사회서비스 관련 교육 및 홍보 } \\
\text { - 지역사회서비스지원기관에 대한 지원 }\end{array}$ \\
\hline $\begin{array}{c}\text { 지역사회 } \\
\text { 서비스 지원단 }\end{array}$ & \multicolumn{2}{|c|}{$\begin{array}{c}\text { 시·도 } \\
\text { 지역사회서비스지원단 }\end{array}$} & $\begin{array}{l}\text { - 서비스 제공기관 대상 컨설팅 } \\
\text { - 서비스 제공기관 현장점검 지원 } \\
\text { - 서비스 홍보 등 지원체계 구축 }\end{array}$ \\
\hline $\begin{array}{c}\text { 서비스 } \\
\text { 제공기관 }\end{array}$ & \multicolumn{2}{|c|}{ 기관 담당자 } & $\begin{array}{l}\text { - 서비스 제공인력 모집 및 교육, 노무관리 } \\
\text { - 서비스 제공 및 모니터링 } \\
\text { - 서비스 비용 청구 및 제공인력 급여 지급 } \\
\text { - 바우처 시스템 활용 }\end{array}$ \\
\hline
\end{tabular}

자료: 보건복지부(2021), 2021 가사.간병 방문 지원사업 안내 


\section{다. 성과평가}

\section{1) 추진경과}

2013년부터 성과평가가 진행되었다. 계획, 집행, 성과, 환류 등 논리모형에 근거하여 지역사회서비스 포괄보조 운영에 대한 17 개 사도의 사업 프로세스 전반을 평가한다. 매 년 성과평가 목적의 전문평가단을 구성하여 사업 계획의 구체성 및 성과관리의 적절성, 서비스 품질관리 및 성과 우수성, 평가결과 환류 등에 대해 영역별 성과지표에 따라 평 가하고 있다. 평가 결과는 우수 및 도약 지방자치단체 표창 및 인센티브 제공, 시도별 예산 배분에 반영하여 지방자치단체 관심 제고와 사업효과성 향상을 유도하고 있다.

〈표 3-18〉 지역자율형사회서비스투자사업 시·도 성과평가 추진 경과('13-'20년)

\begin{tabular}{|c|c|c|c|}
\hline 구분 & 평가지표 & 방법 & 활용 \\
\hline '13년 & $\begin{array}{l}\text { [포괄보조 사업평가] 계획, 집행, 성과 영역의 } 12 \text { 개 지표 평가 관련하여 워 } \\
\text { 크숍과 컨설팅 진행 }\end{array}$ & $\begin{array}{l}\text { 정성 } \\
\text { 정량 }\end{array}$ & $\begin{array}{l}\text { 표창 및 } \\
\text { 예산배분 }\end{array}$ \\
\hline '14년 & $\begin{array}{l}\text { [포괄보조 사업평가] 계획, 집행, 성과, 환류 영역의 } 14 \text { 개 지표에 따라 상 } \\
\text { 반기 계획평가 } \rightarrow \text { 사업컨설팅 } \rightarrow \text { 하반기 실적평가 진행 }\end{array}$ & $\begin{array}{l}\text { 정성 } \\
\text { 정량 }\end{array}$ & $\begin{array}{l}\text { 표창 및 } \\
\text { 예산배분 }\end{array}$ \\
\hline '15년 & $\begin{array}{l}\text { [포괄보조 사업평가] 사회서비스 포괄보조 예산 및 예탁금 관리, 지자체 우 } \\
\text { 수사례 공유 및 관련 쟁점에 대한 심층분석 병행 }\end{array}$ & $\begin{array}{l}\text { 정성 } \\
\text { 정량 }\end{array}$ & $\begin{array}{l}\text { 표창 및 } \\
\text { 예산배분 }\end{array}$ \\
\hline ‘16년 & $\begin{array}{l}\text { [포괄보조 사업평가] 계획, 집행, 성과, 환류 영역의 } 17 \text { 개 지표에 따라 상 } \\
\text { 반기 계획 평가 } \rightarrow \text { 사업컨설팅 } \rightarrow \text { 하반기 실적평가(대면평가) 진행 }\end{array}$ & $\begin{array}{l}\text { 정성 } \\
\text { 정량 }\end{array}$ & $\begin{array}{l}\text { 표창 및 } \\
\text { 예산배분 }\end{array}$ \\
\hline ‘17년 & $\begin{array}{l}\text { [포괄보조 사업평가] 계획, 집행, 성과, 환류 영역의 } 16 \text { 개 지표에 따라 상 } \\
\text { 반기 계획 평가 } \rightarrow \text { 사업컨설팅 } \rightarrow \text { 하반기 실적평가(대면평가) 진행 } \\
\text { [메타평가 시범운영] 시군구 자체평가에 대한 메타평가 시범운영 } \\
\text { [사업 담당자 인식조사] 사업 운영 및 관리 측면에 대한 지자체 담당자 인 } \\
\text { 식조사 실시 }\end{array}$ & $\begin{array}{l}\text { 정성 } \\
\text { 정량 }\end{array}$ & $\begin{array}{l}\text { 표창 및 } \\
\text { 예산배분 }\end{array}$ \\
\hline '18년 & $\begin{array}{l}\text { [포괄보조 사업평가] 계획, 집행, 성과, 환류 영역의 } 10 \text { 개 지표에 따라 상 } \\
\text { 반기 계획 평가 } \rightarrow \text { 사업컨설팅 } \rightarrow \text { 하반기 실적평가(대면평가) 진행 } \\
\text { [사업 관리 통계 현황 조사] 시도 사업관련 통계 운영 실태 파악을 위한 } \\
\text { 조사 실시 }\end{array}$ & $\begin{array}{l}\text { 정성 } \\
\text { 정량 }\end{array}$ & $\begin{array}{l}\text { 표창 및 } \\
\text { 예산배분 }\end{array}$ \\
\hline '19년 & $\begin{array}{l}\text { [시도평가] 계획, 집행, 성과, 환류영역의 } 13 \text { 개 지표에 따라 상반기 계획평 } \\
\text { 가 } \rightarrow \text { 성과관리 컨설팅 } \rightarrow \text { 하반기 실적평가(대면평가) }\end{array}$ & $\begin{array}{l}\text { 정성 } \\
\text { 정량 }\end{array}$ & $\begin{array}{l}\text { 표창 및 } \\
\text { 예산배분 }\end{array}$ \\
\hline '20년 & $\begin{array}{l}\text { [운영총괄평가] 계회(환류), 집행, 성과영역의 } 10 \text { 개 지표 상반기 운영계획 } \\
\text { 평가 } \rightarrow \text { 하반기 실적평가 } \rightarrow \text { 미흡 지자체 컨설팅 } \\
\text { [정책특화평가] 시장 환성화, 복지사각지대 해소, 양질의 사회서비스 일자 } \\
\text { 리 창출, 서비스 품질제고의 } 4 \text { 개 정책영역 우수지역 평가 }\end{array}$ & $\begin{array}{l}\text { 정성 } \\
\text { 정량 }\end{array}$ & $\begin{array}{l}\text { 표창 및 } \\
\text { 예산배분 }\end{array}$ \\
\hline
\end{tabular}

주: 2019년 균특회계 내 계정이 부처 직접편성방식으로 전환됨에 따라 포괄보조 사업평가에서 시도사업평가로 변경 자료: 보건복지부(2021), 2021년도 지역자율형사회서비스투자사업 시도평가 추진계획 


\section{2) 성과평가 체계}

2021년 시도평가는 크게 2가지 영역으로 (1)지역자율형 사회서비스 투자사업 공통 평 가(70점), (2)정책 목적 달성과 연동된 특화 영역 평가(30점)로 구분된다. 공통평가는 원 칙적으로 재정사업 자율평가방식에 근거하며, 사업수행 기관의 운영 및 관리책임성을 확 인점검 평가한다. 지역특화평가는 복지 사각지대 해소, 양질의 사회서비스 일자리 창출, 서비스 효과성 향상 등 지역자율형 사회서비스 투자사업 목적 달성과 연동된 평가 영역 을 신설한 것이다.

시도평가 절차는 (1)전문평가단 구성 및 평가지표 확정('21. 5월), (2)상반기 사업계획 서 작성 및 평가('21. 6월), (3)하반기 실적보고서 작성 및 평가('21. 11월), (4)평가결과 확정 및 평가의견서 전달('21. 12월) 순으로 진행된다.

〈표 3-19〉 지역자율형사회서비스투자사업 시도평가 추진절차

\begin{tabular}{|c|c|c|}
\hline \multicolumn{2}{|r|}{ 구분 } & 주요내용 \\
\hline 1단계 & $\begin{array}{l}\text { 전문 평가단 구성 } \\
\text { 및 평가지표 확정 } \\
\quad \text { ('21. 5월) }\end{array}$ & $\begin{array}{l}\text { - (전문 평가단 구성) 평가 내실화 및 전문성 확보를 위하여 지역별 사회서비 } \\
\text { 스 전문가 추천 등을 통한 전문 평가단 구성 } \\
\text { - (평가지표 확정) 공통 평가 및 지역 특화 평가 영역 세부 평가지표 및 배점 } \\
\text { 확정 }\end{array}$ \\
\hline 2단계 & $\begin{array}{l}\text { 상반기 사업계획서 } \\
\text { 작성 및 평가 } \\
\text { ('21. 6월) }\end{array}$ & $\begin{array}{l}\text { - (상반기 사업계획서 작성 및 제출) 사도는 지역자율형 사회서비스 투자사업 } \\
\text { 의 } 2020 \text { 년도 추진 계획을 작성하여 평가기관에 제출('20. 6월) } \\
\text { * 평가 자료: 상반기 사업계획서 파일을 평가기관에 전자파일 형태로 제출하 } \\
\text { 며, 별도의 출력 자료(관련 근거자료)가 있을 경우 기한 내 우편으로 접수 } \\
\quad \text { 되어야 함. } \\
\text { - (서면평가) 사도 제출 자료를 바탕으로 평가위원들은 서면평가를 진행하여 } \\
\text { 점수(안) 산출 } \\
\text { - (컨설팅) 부진지표에 대한 맞춤형 개별컨설팅을 통해 평가 결과에 대한 피 } \\
\quad \text { 드백의 적절성 및 공정성 확보 }\end{array}$ \\
\hline 3단계 & $\begin{array}{l}\text { 하반기 실적보고서 } \\
\text { 작성 및 평가 } \\
\text { ('21. 11월) }\end{array}$ & $\begin{array}{l}\text { - (하반기 실적보고서 작성 및 제출) 사도는 작성 양식을 참고하여 2021년도 } \\
\text { 사업 종료에 따른 실적보고서를 평가기관에 제출('21. 11월) } \\
\text { - (서면평가) 시도 제출 자료를 바탕으로 평가위원들은 서면평가를 진행하여 } \\
\text { 점수(안) 산출(' } 21.12 \text { 월) } \\
\text { * 평가 자료: 하반기 실적보고서 파일을 평가기관에 전자파일 형태로 제출하 } \\
\quad \text { 며, 별도의 출력 자료(관련 근거자료)가 있을 경우, 기한 내 우편으로 접수 } \\
\quad \text { 되어야 함. }\end{array}$ \\
\hline 4단계 & $\begin{array}{l}\text { 평가결과 확정 및 } \\
\text { 평가의견서 전달 } \\
\text { ('21. 12월) }\end{array}$ & $\begin{array}{l}\text { - (평가결과 확정) 상반기 사업계획서 및 하반기 실적보고서 평가결과를 바탕 } \\
\text { 으로 지표별 최종 점수 및 평가 등급 확정 } \\
\text { - (평가의견서 전달) 평가단은 사도별 최종 평가 결과 및 평가 의견서 전달 }\end{array}$ \\
\hline
\end{tabular}

자료: 보건복지부(2021), 2021년도 지역자율형사회서비스투자사업 시도평가 추진계획 


\section{3) 성과평가 지표}

공통평가는 계획 및 집행 영역은 정성 지표로 구성되어 있고 이외 계량화가 가능한 실적 영역은 정량 지표로 평가한다. 계획 및 집행 30점과 실적 70점이 부여되고 관리가 점 5점이 있다. 영역별 점수를 합산하여 총점 100 점(가점 +5$)$ 으로 산출하고, 절대평가 방식으로 5단계의(S, A, B, C, D) 종합 평가등급을 부여하여 결과를 확정한다.

〈표 3-20〉지역자율형사회서비스 투자사업 시도평가 지표(공통평가)

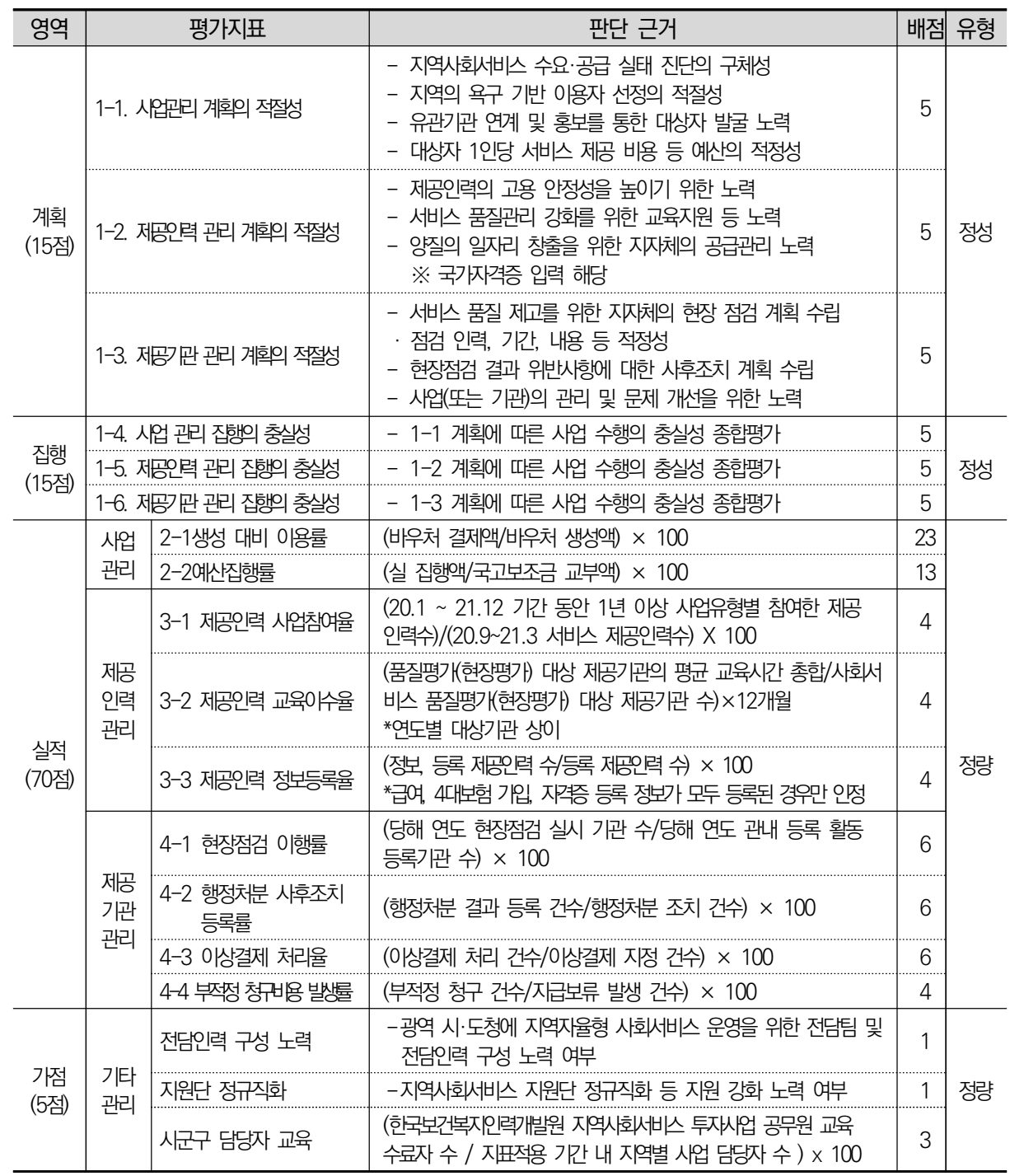

주: 2-1, 2-2, 4-1, 4-2, 4-3, 4-4 는 내역사업별 가중치 적용

자료: 보건복지부(2021), 2021년도 지역자율형사회서비스투자사업 시도평가 추진계획 
지역특화평가는 지역자율형 사회서비스 투자사업의 목적 달성을 위해 지역 특성을 반 영하여 추진하고 있는 내용을 계획(35점), 집행(30점), 성과(35점) 영역으로 구성하고 정성지표로 평가한다. 여기서 계획은 계획 수립의 지역적 특수성, 독창성, 계획 내용의 충실성, 집행은 수립 계획의 이행도 및 충실성, 모니터링 및 상황변화 대응도, 성과는 성과지표와 목표의 적정성, 성과지표의 목표치 달성도에 관한 것이다. 평가영역은 (1)사 회서비스 사각지대 해소, (2)양질의 사회서비스 일자리 창출, (3)서비스 효과성 향상으로 총 3개 영역을 평가한다. 평가방식은 사도별 사업계획서 및 실적보고서에 지방자치단체 가 지역특화 부문으로 선정한 과제들을 중심으로 서면평가를 진행하고 평가영역 3가지 별 우수 지역을 각 1 곳씩 선정한다.

〈표 3-21〉 지역자율형사회서비스 투자사업 시도평가 지표(지역특화평가)

\begin{tabular}{|c|c|c|c|}
\hline \multicolumn{2}{|r|}{ 평가 기준 } & 점수 & 배점 기준 \\
\hline 기획 & $\begin{array}{l}\text { A-1. 관련 추진과제가 해당 정책 목적의 실현을 위해 지역 } \\
\text { 의 특수성을 반영하여 타당하고 독창적으로 계획되었 } \\
\text { 는가? }\end{array}$ & 35 & $\begin{array}{l}\text {-(탁월) 33-35 } \\
\text {-(우수) 30-32 } \\
\text {-(보통) 27-29 } \\
\text {-(미흡) 24-26 } \\
\text {-(아주미흡) 23-25 }\end{array}$ \\
\hline 집행 & $\begin{array}{l}\text { A-2. 관련 추진과제가 계획대로 이행되고, 이행과정에서 } \\
\text { 장애요인 극복을 위한 다양한 노력을 기울였는가? }\end{array}$ & 30 & $\begin{array}{l}\text {-(탁월) 28-30 } \\
\text {-(우수) 25-27 } \\
\text {-(보통) 22-24 } \\
\text {-(미흡) 19-21 } \\
\text {-(아주미흡) 16-18 }\end{array}$ \\
\hline 성과 & $\begin{array}{l}\text { A-3. 관련 추진과제가 의도한 성과가 가시적이고, 과제의 } \\
\text { 지속가능성이 있는가? }\end{array}$ & 35 & $\begin{array}{l}\text {-(탁월) 33-35 } \\
\text {-(우수) 30-32 } \\
\text {-(보통) 27-29 } \\
\text {-(미흡) 24-26 } \\
\text {-(아주미흡) 23-25 }\end{array}$ \\
\hline
\end{tabular}

자료: 보건복지부(2021), 2021년도 지역자율형사회서비스투자사업 시도평가 추진계획

〈표 3-22〉 지역자율형사회서비스 투자사업 시도평가 영역(지역특화평가)

\begin{tabular}{l|l}
\hline \multicolumn{1}{c|}{ 평가영역 } & \multicolumn{1}{c}{ 예시 } \\
\hline (1) 사회서비스 사각지대 해소 & $\begin{array}{l}\text { 서비스 신청 및 이용 접근성 향상, 욕구 기반 이용자 선정, } \\
\text { 공급 과소 지역 대응 전략, 유관기관 연계·협력 등 }\end{array}$ \\
\hline (2) 양질의 사회서비스 일자리 창출 & 신규 일자리 창출, 일자리 질 개선을 위한 계획 등 \\
\hline (3) 서비스 효과성 향상 & 제공기관 및 제공인력 전문성 향상, 서비스 품질 관리 계획 등 \\
\hline
\end{tabular}

자료: 보건복지부(2021), 2021년도 지역자율형사회서비스투자사업 시도평가 추진계획 


\section{제3절 지역사회 통합건강증진사업(복지부)}

\section{1. 사례개요}

\section{가. 지역사회 통합건강증진사업 개념}

지역사회 통합건강증진사업은 2013년부터 지방자치단체가 지역사회 주민을 대상으 로 건강생활의 실천과 만성질환의 예방, 취약계층의 건강관리를 목적으로 지역사회 특성 과 주민의 요구가 반영된 프로그램 및 서비스 등을 기획·추진하는 사업이다.

2013년 ‘방문건강관리', ‘지역사회중심재활’ 등 17 개 개별 국고보조사업을 1 개 포괄 적 국고보조사업으로 통합하고, 사업영역을 '금연', '절주’ 등 건강목표 건강영역 중심의 13 개 로 구분하여 지방자치단체가 내역사업을 자율적으로 설계·집행할 수 있도록 운영 하고 있다. 기존의 개별 국고보조사업과 달리 사업 영역 간 경계를 없애고, 주민 중심으 로 사업을 통합·협력하여 수행하는 방식이다.

[그림 3-6] 통합건강증진사업 포괄보조 통합 내역

\begin{tabular}{|l}
\hline (1) 보건소 방문건강관리 \\
(2) 지역사회중심재활 \\
(3) 보건소 건강생활실천통합서비스 \\
(4) 영양플러스사업 \\
(5) 보건소 금연클리닉 \\
\hline (6) 모유수유클리닉 운영 \\
(7) 철분제, 엽산제 지원 \\
(8) 구강보건실(센터) 설치운영 \\
(9) 어린이 구강건강관리 \\
(10) 노인 불소도포 - 스케일링 \\
(11) 수돗물불소농도조정 지자체 보조 \\
(12) 치매조기검진사업 \\
\hline (13) 치매노인사례관리 \\
\hline (14) 한의약건강증진Hub보건소 \\
(15) 한의약 지역보건사업 \\
(16) 아토피천식 예방관리 \\
\hdashline (17) 심뇌혈관질환 예방관리· 교육 \\
\hline
\end{tabular}

$\Rightarrow$\begin{tabular}{|l|}
\hline \\
(1) 금연 \\
(2) 절주 \\
(3) 신체활동 \\
(4) 영양 \\
(5) 비만 \\
(6) 구강보건 \\
(7) 심뇌혈관질환 예방관리 \\
(8) 한의약 건강증진 \\
(9) 아토피 천식 예방관리 \\
(10) 여성어린이 특화 (모자보건) \\
(11) 치매관리 \\
(12) 지역사회중심재활 \\
(13) 방문 건강관리 \\
\end{tabular}


[그림 3-7] 지역사회 통합건강증진사업의 비전과 전략

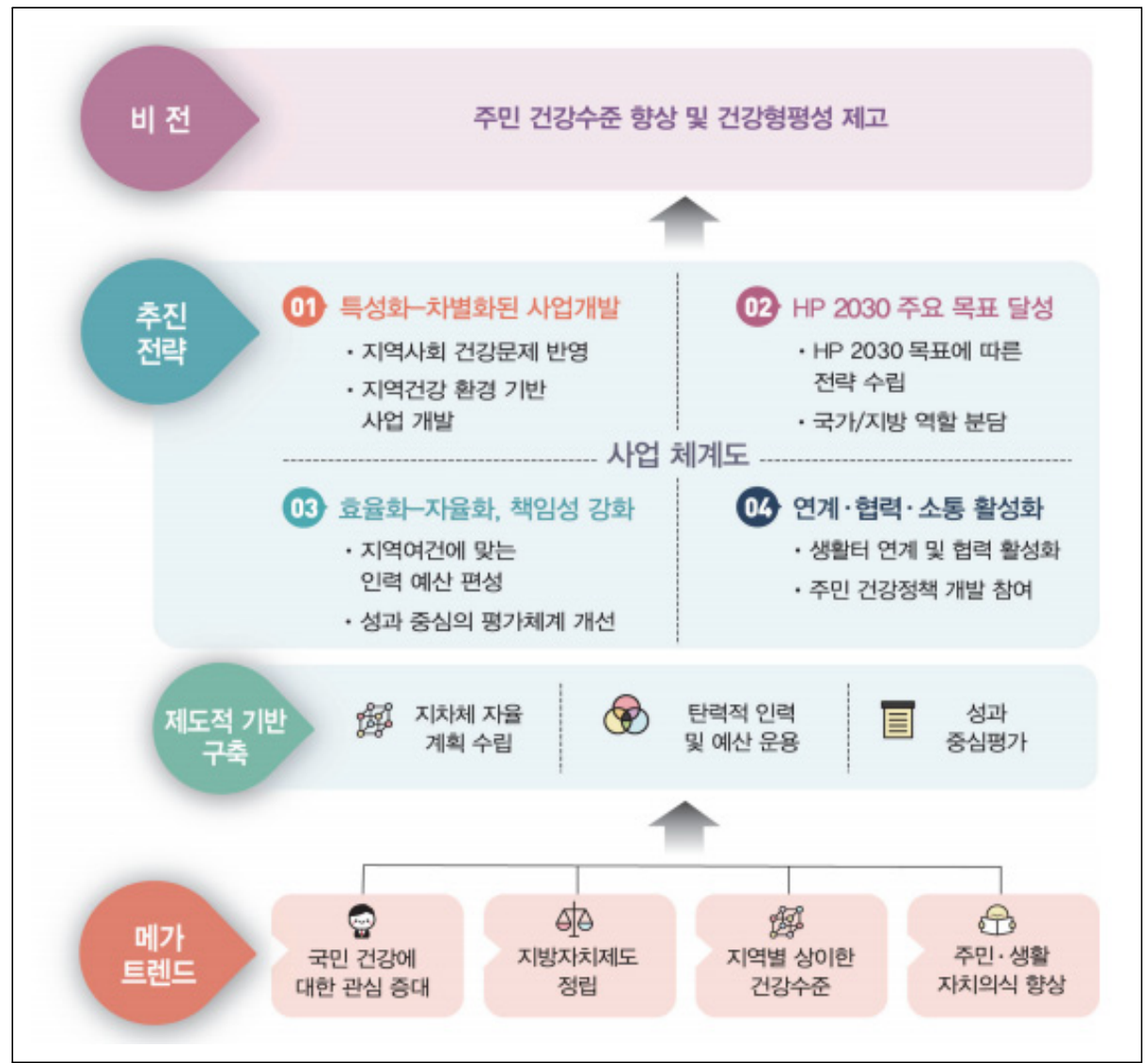

자료: 보건복지부(2020), 2021년 지역사회 통합건강증진사업 안내

지방자치단체(보건소)별 예산액을 기준으로 다양한 건강증진 사업 분야에서 지역 여 건에 따라 단위사업을 자율적으로 기획 · 추진한다. 이는 기존의 국고보조사업이 사업내 용과 방법을 지침으로 지정하여 지역 여건에 무방한 사업을 하향식으로 전달하여 추진 한 반면, 본 사업은 사업의 범위와 추진원칙을 지침으로 명시하고 지역 여건에 맞는 사 업을 지역기반으로 기획하여 설계·추진한다는 점에서 근본적인 차이가 있다.

기존 국고보조사업은 산출 중심의 사업평가에 치중하게 되지만 지역사회통합건강증 진사업은 과정과 성과중심의 평가를 강조한다. 국고보조사업이 분절적 사업수행에 따른 비효율성의 문제를 제기할 때, 본 사업은 보건소 내외 사업의 통합과 연계 활성화 방안 을 고려하는 것이다. 


\section{나. 추진배경}

1995 국민건강증진법 제정에 따라 건강증진기금을 조성, 국가차원의 건강증진 사업 을 추진할 수 있는 제도적 기반이 마련되었고, 1998 년 하반기 전국 18 개 거점 보건소를 중심으로 건강증진 시범사업 운영을 시작으로 2005년 전국 모든 보건소에 사업이 확대 되었다. 2016년 제4차 국민건강증진종합계획 2020(HP 2020)에 따라 다양한 건강증진 사업을 추진하고 있는 보건소는 지방자치단체가 자체적으로 계획한 건강증진사업 뿐만 아니라 중앙정부의 건강정책을 지역사회에서 실현하는 중심역할을 담당하게 되었다. 지 역사회 통합건강증진사업은 다음과 같이 변화를 겪었다.

〈표 3-23〉 지역사회 통합건강증진사업 변화 경과

건강생활실천사업(2005 ): 금연, 절주, 운영, 영양을 필수사업으로 추진

지역특화건강행태개선사업(2008 ): 금연, 절주, 운동, 영양을 지역 필요에 따라 선택적 통합 추진 건강생활실천 통합서비스사업(2012 ): 개인별 통합서비스 제공 지역사회 통합건강증진사업(2013 ): 13개 분야 통합(8대 필수서비스)

사업수행의 기본 방향을 크게 다음 2 가지로 정리할 수 있다. 먼저 건강증진사업 통합 및 재편성을 통한 사업의 효율성 제고이다. 보건소 중심의 지역보건의료계획 및 국민건 강증진종합계획에 부합하도록 사업구조를 재편성하였다. 지역주민의 건강증진 사업목표 가 달성될 수 있도록 사업을 건강영역별 또는 생애주기별로 통합 구성하여 지역사회 자 원과 포괄적 연계협력을 통한 대상자 중심의 통합서비스를 제공 여건이 조성되었다.

두 번째는 지방자치단체의 자율성 확대 및 지방자치단체의 책임성 제고이다. 지방자 치단체가 재원의 용도 및 세부내역을 자율적으로 설계하고 집행할 수 있도록 개선하는 한편, 지역사회 건강문제 및 특성에 따라 우선순위 사업영역 선정 및 사업량 선택의 자 율적 운영이 가능하다. 사업운영의 자율성을 부여하는 동시에, 책임성을 담보하기 위해 지방자치단체 스스로 관라감독 역할을 강화하고, 사업의 기획, 운영, 평가과정에서 지방 자치단체의 자발적 성과관리가 이루어질 수 있도록 평가관리 체계를 운영하고 있다. 


\section{2. 운영방식}

\section{가. 추진절차}

보건복지부는 시도에 국고보조금 사전 통보(임시통보(가내시), 9월)를 하고, 시도는 관할 사군구에 국고보조금 통보한다. 시·도 및 시·군·구는 통보받은 국고보조금을 토대 로 사업계획을 수립하고 예산을 편성한다. 시·군·구는 사업계획을 작성하여 시도에 제출 하는데, 이때 시·도는 시·도 정책방향, 시·도의 역할, 시·군·구의 의견을 수렴하여 시·도 사업계획 수립한다. 사업계획서는 지역적 특성과 주민의 건강요구, 평가지표 등을 고려 하여 작성한 후 시·도 검토 후 시·도를 통하여 보건복지부로 제출한다. 시·도 및 지원단 은 지방비 부담 능력, 시·도 정책방향 등을 토대로 관할 시군구 사업계획의 종합 검토 및 환류를 실시한다. 시·도는 시·군·구 사업계획서를 안내서에 따라 사업계획서 내용의 적정성, 합리적 성과목표 설정 여부와 예산 편성 유의사항 등을 종합검토하고, 시도지원 단은 관할 시·군·구의 사업계획 종합검토 및 환류 결과를 보건복지부에 보고한다.

[그림 3-8] 지역사회 통합건강증진사업 추진절차

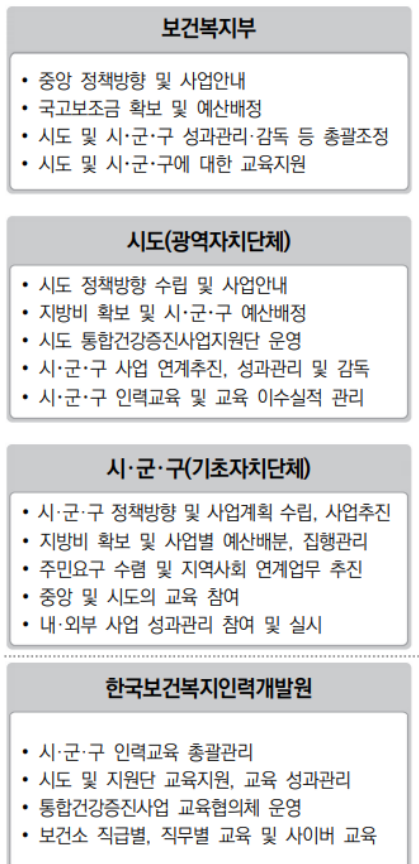

\section{한국건강증진개발원}

- 중앙 정책방향 수립 및 사업안내 추진지원 - 시도 및 시·군·구 사업 성과관리 (사업관리, 모니터링 및 평가-환류) 기술지원 - 시도 및 시·군·구 사업운영 총괄지원

- 우수사례 발굴 및 사업성과 확산

\section{시도 통합건강증진사업지원단}

- 시도 정책방향 설정지원

- 시도 및 시·군·구 계획수립, 사업수행 지원

- 시도 교육계획 수립 및 수행 지원

- 시·군·구 사업 성과관리(현장방문 모니터링, 평가·환류 등) 지원 
통합건강증진사업의 경우 사업간 칸막이가 없어 유기적으로 연계하여 사업 설계가 가 능하다. 보건복지부 건강정책과에서 사업을 총괄하고, 지방자치단체는 시군구단위의 보 건소를 중심으로 사업의 전달체계가 일원화 되어 있다. 990 억원 규모의 소규모 사업으 로 집행체계가 일원화되어 있고 지방자치단체단위에서 총괄적으로 사업을 운영하는 담 당자가 있어 사업운영 및 조정이 용이하다.

\section{나. 사업내용}

사업영역의 경계를 허물고 지역주민을 중심으로 사업 간 연계·협력하여 수행하는 것 을 권장하되 각 시·군·구별로 배분한 예산을 기준으로 일정한 사업 범위 내에서 자율적 으로 기획하고 설계하여 수행한다. 사업영역은 음주폐해예방(절주), 신체활동, 영양, 비 만예방관리, 구강보건, 심뇌혈관질환 예방관리, 한의약건강증진, 아토피·천식 예방관리, 여성어린이특화, 지역사회중심재활, 금연, 방문건강관리, 치매관리로 구성되어있다.

사업계획은 중장기적 사업추진의 방향과 지역사회 특성을 반영한 실행계획의 수립에 따른 사업 목표를 지향한다. 건강 환경의 변화 및 국가 중장기 목표와 지역사회 건강증 진 목표(지역보건의료계획)를 고려하고 지역사회의 현황, 주민요구도, 건강영향요인 등 을 반영한 지역 맞춤형 통합건강증진사업 계획을 수립해야 한다.

[그림 3-9] 지역사회 통합건강증진사업의 구성요소

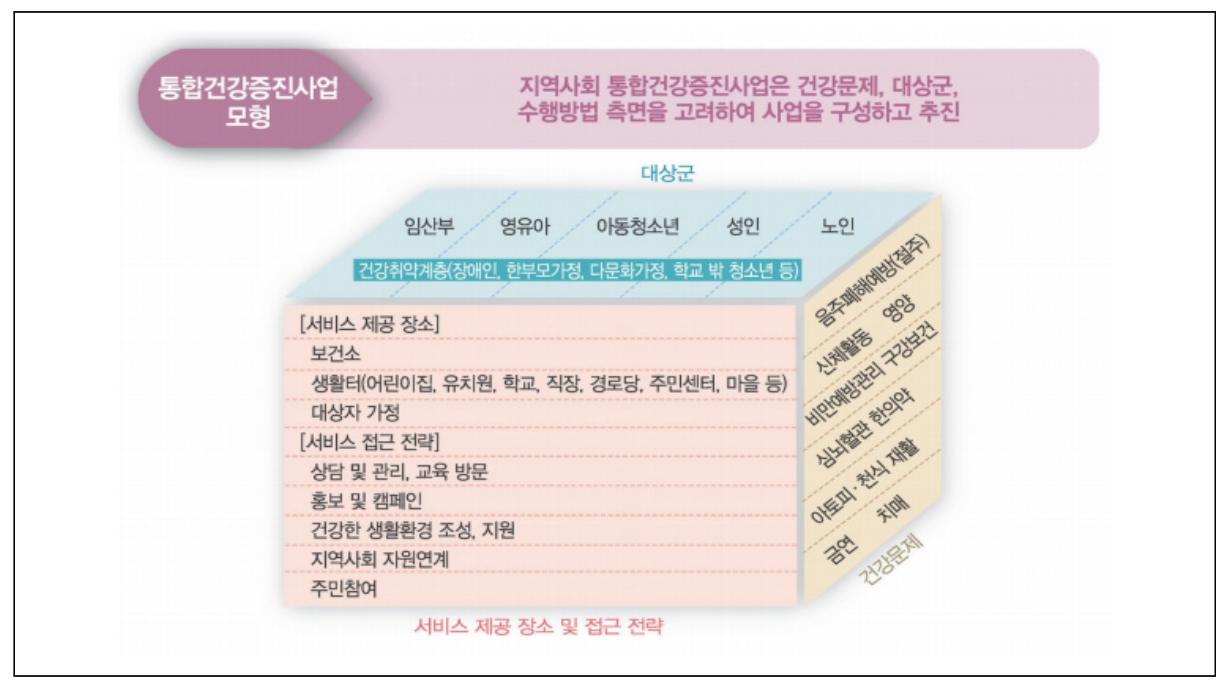

자료: 보건복지부(2020), 2021년 지역사회 통합건강증진사업 안내 


\section{다. 성과평가}

\section{1) 추진경과}

지방자치단체에 사업운영 자율성을 부여하되 사업추진 과정 및 성과의 책임성을 증진 하기 위한 성과관리 체계를 강화하였다. 2017년부터는 정량지표를 도입하고 핵심성과 지표를 마련하였으며, 장.단기 구분없이 세부사업별 성과지표를 수립하도록 하고 평가 결과를 국고보조금 배분근거로 활용하도록 개편하였다.

단순 산출실적 확인이 아닌, 사업기획·운영·평가·환류 전반과정에 대한 성과를 점검 하고 관리하는 체계로서, 지역별 건강증진사업의 자율적 기획, 운영, 예산편성에 대한 책임성 있는 사업수행 및 발전적 환류를 유도한다. 시도는 지원단과 함께 평가결과가 부진한 지방자치단체에 대하여 원인을 분석하고, 개선할 수 있도록 지원하고, 보건복지 부는 시도 및 시군구 사업계획 및 결과보고서를 토대로 우수 기관 및 담당자를 포상한다. 시도별 평가결과 종합, 검토 후 포상대상(우수분야, 개선분야 등) 결정하고, 국고보조금 재원배분 시 사업 평가 결과를 근거로 우수기관 차등 배분한다. 또한「지방자치단체 건 강증진사업 성과대회」시 우수시례 컨퍼런스 참여, 우수시례집 발간·배포 등을 통해 우수 사례를 공유·확산하고 있다.

[그림 3-10] 지역사회 통합건강증진사업 성과평가 추진경과

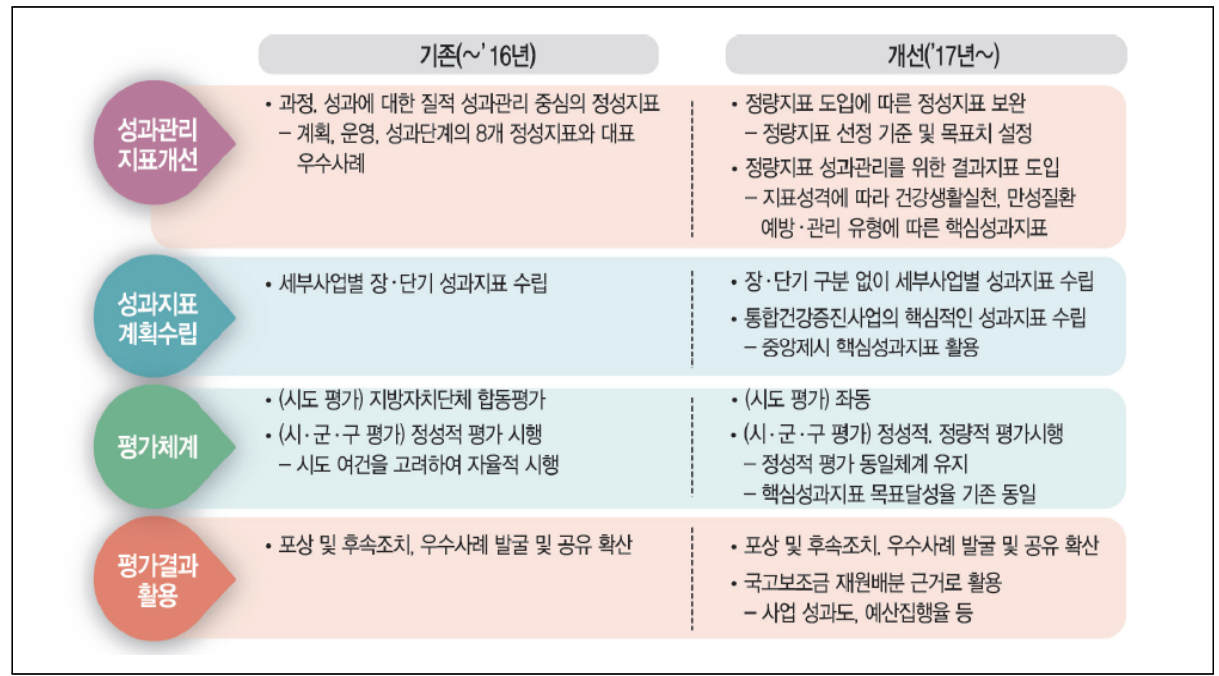

자료: 보건복지부(2020), 2021년 지역사회 통합건강증진사업 안내 


\section{2) 성과평가 체계}

사업계획에 따른 사업 운영 현황 및 성과에 대해 내·외부 모니터링, 자체평가를 실시 하고, 그 결과에 따른 환류를 실시한다. 시·군·구는 사업수행 결과보고서를 작성하여 시·도에 제출하며, 시·도는 별도의 평가단을 구성하여 공정한 시·도 내 평가를 수행하고 그 결과를 시·군·구에 환류하여 차년도 사업기획에 반영할 수 있도록 지원한다. 시도 결 과보고서(시도 평가결과서, 지원단 결과보고서 포함), 시·군·구별 결과보고서, 그 밖의 취합자료를 보건복지부로 제출하고 보건복지부는 시도 평가결과를 토대로 우수기관 선 정, 포상 등의 근거자료로 활용한다.

자체평가 중심의 성과관리를 통해 자율성 및 책임성 확보하고, 단기적인 사업성과 뿐 아니라 지역의 보건환경 변화에 대응하여 지역사회 건강수준 향상 및 건강격차 감소를 위한 목표관리를 시행하고 있다. 성과목표는 중앙에서 제시하는 16 개 결과지표 중에서 선택하는 핵심성과목표(국민건강증진종합계획 연관지표)와 시도 및 시·군·구에서 세부 사업별로 자율적으로 작성하는 자체성과목표로 구분된다.

핵심성과지표는 중앙에서 제시하는 객관적 정량지표로써, 지역사회 건강수준 향상 및 건강격차 감소를 위한 지역의 건강지표관리에 목적이 있다. 핵심성과지표는 지방자치단 체에서 중점을 두고 지향하거나 궁극적으로 변화시키고자 하는 핵심성과지표를 아래의 16 개 정량지표 중 자율적으로 설정하고, 지표별 과거 추세치, 현수준, 국가건강증진목표 등을 고려하여 목표치를 설정한다.

〈표 3-24〉2021년 지역사회 통합건강증진사업 핵심성과지표

\begin{tabular}{l|l}
\hline \multicolumn{1}{c|}{ 건강생활 실천 } & \multicolumn{1}{c}{ 만성질환 예방·관리 } \\
\hline (1) 성인 남자 현재흡연율 & \\
(2) 현재흡연자의 1개월 내 금연계획률 & \\
(3) 비흔연자의 직장실내 간접흡연 노출률 & \\
(4) 월간 음주율 & (13) 혈압수치 인지율 \\
(5) 고위험 음주율 & (14) 혈당수치 인지율 \\
(6) 영양표시 활용율 & (15) 1년 후 300일 이상 고혈압 투약 순응률 \\
(7) 아침결식 예방인구비율 & (16) 1년 후 300일 이상 당뇨 투약 순응률 \\
(8) ㄱㅓㅓㄱㅣ 실천율 & \\
(9) 중등도 이상 신체활동 실천율 & \\
(10) 비만유병률 & \\
(11) 모유수유 실천율 & \\
(12) 어제 점심식사 후 칫솔질 실천율 & \\
\hline
\end{tabular}

주: (11), (15), (16) 국민건강보험공단 건강보험통계, 그 외 지역사회 건강조사

자료: 보건복지부(2020), 2021년 지역사회 통합건강증진사업 안내 
자체성과지표는 시도 및 시·군·구에서 세부 사업별로 자율적으로 작성한 성과지표로 써, 사업의 운영, 결과에 대하여 자체적인 모니터링 등 성과관리에 목적이 있다. 세부사 업계획에 따라 수행과정, 사업결과 및 효과에 대해 자체 점검(모니터링, 평가)이 가능한 하도록 가급적 투입-과정-산출-결과로 구분하고, 결과지표 중심으로 설정한다. 평가 절 차는 시도 여건에 맞춰 평가단을 구성하고, 시도에서 관할 시·군·구의 사업 정성평가 및 정량평가를 실시한다.

〈표 3-25〉2021년 지역사회 통합건강증진사업 평가단 구성·운영 권장사항

- 시도는 평가가 공정하게 수행될 수 있도록 관리

- 지역별로 평가위원을 배치할 경우, 1 명이 10 개 이상 지역을 평가하지 않도록 교차 배치 권장 ※ 평가지표별로 평가위원을 배치하여 평가하는 방안 검토 요망

- 평가대상 당 2 인 이상 평가 권장

- 평가단의 평가위원 구성

- 평가위원 수는 평가대상 지역 수를 고려하여 선정

- 지역사회 건강증진사업에 대한 지식과 식견을 갖춘 전문가로 구성

- 객관성을 유지할 수 있도록 평가대상 보건소와 이해관계가 없는 위원으로 구성하고, 타 지역의 전문가 $30 \%$ 이상 참여 (우수사례 평가 시 타 지역 평가위원은 배제 가능)

자료: 보건복지부(2020), 2021년 지역사회 통합건강증진사업 안내

\section{3) 성과평가 지표}

평가영역은 사업의 계획, 운영, 성과, 우수시례단계로 구분되어 있고 정성 $80 \%$, 정량 $20 \%$ 로 구성되어 있다. 시·군·구별 인구, 예산, 지역형태 및 건강문제의 다양성을 감안하 여 정성적 평가지표 비율이 높고, 정량지표는 핵심성과지표 목표치 달성(10), 자체성과 지표 목표치 달성(5), 예산집행률(5)로 구성되어 있다.

사업계획 영역에서는 건강문제와 사업목표 사업대상 및 사업전략과 환류의 연계성을 점검하고, 내·외부 모니터링 및 평가결과에 대한 환류부분 강조하며, 사업운영 영역에서 는 보건소 내부소통과 협력과정을 통한 사업운영, 지역사회 자원의 지속적-자발적 참여 현황을 점검한다. 사업성과 영역에서는 자체 계획에 대한 책임성 있는 운영 점검 및 핵 심성과목표, 자체 성과목표 및 예산집행률 등 객관적인 성과를 평가하고, 우수사례는 계 획의 타당성, 운영의 노력성, 사업의 효과성과 더불어 우수사례의 지속발전을 위한 확 산·활용 가능성 및 지속·발전성을 점검한다. 
〈표 3-26〉 2021년 지역사회 통합건강증진사업 평가지표 총괄표

\begin{tabular}{|c|c|c|c|}
\hline 영역 & 평가지표 & 배점 & 평가자료 \\
\hline \multirow{3}{*}{$\begin{array}{c}\text { 계획 } \\
\text { (정성 25) }\end{array}$} & 1. 지역현황과 연계성 있는 성과지표(목표)를 선정하였는가? & 12 & 계획서 \\
\hline & 2. 사업목표에 맞는 사업내용을 계획하였는가? & 10 & 계획서 \\
\hline & 3. 사업목표치는 합리적으로 수립하였는가? & 3 & 계획서 \\
\hline \multirow{3}{*}{$\begin{array}{c}\text { 운영 } \\
\text { (정성 30) }\end{array}$} & 4. 내부자원과 소통·협력하여 사업을 운영하였는가? & 5 & 결과보고서 \\
\hline & 5. 지역사회 자원과의 연계협력을 적극적으로 추진하였는가? & 10 & 결과보고서 \\
\hline & 6. 사업계획에 맞추어 사업을 충실히 운영하였는가? & 15 & 계획서, 결과보고서 \\
\hline \multirow{2}{*}{$\begin{array}{c}\text { 성과 } \\
\text { (정량 } 20 \text { 정성 5) }\end{array}$} & 7. 계획한 목표치를 달성하였는가? & 20 & 계획서, 결과보고서 \\
\hline & 8. 계획된 예산을 충실히 집행하였는가? & 5 & 계획서, 결과보고서 \\
\hline \multirow{2}{*}{ 우수사례(정성 20) } & 9. 대표 우수사례 & 20 & 결과보고서 \\
\hline & 총계(정성 80, 정량 20) & 100 & \\
\hline
\end{tabular}

자료: 보건복지부(2020), 2021년 지역사회 통합건강증진사업 안내

〈표 3-27〉 2021년 지역사회 통합건강증진사업 세부평가지표

\begin{tabular}{|c|c|c|}
\hline 평가지표(배점) & 세부평가지표 & 배점 \\
\hline $\begin{array}{l}\text { 1. 지역현황과 연계성 있는 } \\
\text { 성과지표(목표)를 선정 } \\
\text { 하였는가?(12) }\end{array}$ & $\begin{array}{l}\text { 가. 신뢰성 있는 자료를 통해 지역현황을 파악하였는가? } \\
\text { 나. 건강취약(건강사각지대, 취약계층) 현황을 파악하였는가? } \\
\text { 다. 지역현황에 맞는 핵심성과지표(목표)를 선정하였는가? } \\
\text { 라. 지역현황에 맞는 자체성과지표(목표)를 선정하였는가? }\end{array}$ & $\begin{array}{l}3 \\
3 \\
3 \\
3\end{array}$ \\
\hline $\begin{array}{l}\text { 2. 사업목표에 맞는 사업내 } \\
\text { 용을 계획하였는가? } \\
\text { (10) }\end{array}$ & $\begin{array}{l}\text { 가. 목표에 맞는 사업대상(건강취약대상 포함)을 선정하였는가? } \\
\text { 나. 목표에 맞게 건강영역을 통합하여 사업계획을 하였는가? } \\
\text { 다. 목표에 맞는 다양한 사업전략을 투입하였는가? } \\
\text { 라. 주민의 의견수렴과정을 통해 사업계획을 수립하였는가? }\end{array}$ & $\begin{array}{l}4 \\
2 \\
2 \\
2\end{array}$ \\
\hline $\begin{array}{l}\text { 3. 사업목표치는 합리적으로 } \\
\text { 수립하였는가?(3) }\end{array}$ & 좌동 & 3 \\
\hline $\begin{array}{l}\text { 4. 내부자원과 소통·협력하 } \\
\text { 여 사업을 운영하였는 } \\
\text { 가?(5) }\end{array}$ & $\begin{array}{l}\text { 가. 보건소 내 관계부서와의 소통·협력과정이 정례적이고, 충실하게 } \\
\text { 이루어졌는가? } \\
\text { 나. 보건소 내 소통·협의과정에 보건소장 및 팀장 이상 관리자들의 참여와 } \\
\text { 지원이 충분하였는가? }\end{array}$ & 2 \\
\hline $\begin{array}{l}\text { 5. 지역사회 자원과의 연계 } \\
\text { 협력을적극적으로 추진 } \\
\text { 하였는가?(10) }\end{array}$ & $\begin{array}{l}\text { 가. 사업전략에 맞는 지역사회 자원을 발굴·투입하였는가? } \\
\text { 나. 지역사회 자원이 각 역할을 가지고 사업에 참여하였는가? } \\
\text { 다. 지역사회 자원이 지속적, 자발적 참여가 이루어 질 수 있도록 } \\
\text { 노력하였는가? }\end{array}$ & $\begin{array}{l}3 \\
3 \\
4\end{array}$ \\
\hline $\begin{array}{l}\text { 6. 사업계획에 맞추어 사업 } \\
\text { 을 충실히 운영하였는 } \\
\text { 가?(15) }\end{array}$ & $\begin{array}{l}\text { 가. 계획된 일정대로 원활히 사업이 운영되었는가? } \\
\text { 나. 내·외부 모니터링(중간평가)을 충실히 수행하였는가? } \\
\text { 다. 내·외부 모니터링 및 평가결과를 사업추진 시 수정·반영 하였는가? } \\
\text { 라. 계획된 사업내용이 충실히 운영되었는가? }\end{array}$ & $\begin{array}{l}3 \\
4 \\
4 \\
4\end{array}$ \\
\hline $\begin{array}{l}\text { 7. 계획한 목표치를 달성하 } \\
\text { 였는가?(20) }\end{array}$ & $\begin{array}{l}\text { 가. 결과보고서의 성과지표 및 목표치가 계획서와 일치하는가? } \\
\text { 나. 핵심성과지표의 목표치를 달성하였는가? (정량) } \\
\text { 다. 자체성과지표의 목표치를 달성하였는가? (정량) }\end{array}$ & $\begin{array}{c}5 \\
10 \\
5\end{array}$ \\
\hline $\begin{array}{l}\text { 8. 계획된 예산을 충실히 집 } \\
\text { 행하였는가?(5) }\end{array}$ & 좌동(정량) & 5 \\
\hline 9. 대표 우수사례(20) & $\begin{array}{l}\text { 가. 계획의 타당성 } \\
\text { 나. 운영의 노력성 } \\
\text { 다. 사업의 효과성 } \\
\text { 라. 확산·활용 가능성 } \\
\text { 마. 지속·발전성 }\end{array}$ & $\begin{array}{l}5 \\
5 \\
5 \\
3 \\
2 \\
\end{array}$ \\
\hline \multicolumn{2}{|c|}{ 총계(정성 80, 정량 20) } & 100 \\
\hline
\end{tabular}

자료: 보건복지부(2020), 2021년 지역사회 통합건강증진사업 안내 


\section{제4절 문화도시 조성사업(문체부)}

\section{1. 사례개요}

\section{가. 문화도시 조성사업 개념}

문화도시란 지역별로 특색 있는 문화자원을 효과적으로 활용해 지역의 문화 창조력을 강화할 수 있도록 '지역문화진흥법15)'에 따라 지정된 도시를 말한다. 2021년 문화도시 추진 가이드라인에 따르면, 문화도시 추진의 비전은 '문화를 통한 지속가능한 지역발전 및 지역주민의 문화적 삶 확산'으로 정하고 있다. 문화체육관광부장관이 문화도시심의위 원회의 심의를 거쳐 문화도시로 지정하면 각 문화도시에 5년간 최대 국비 100 억원(지방 비 매칭 5:5, 총사업비 200억원)이 지원된다.

〈표 3-28〉 문화도시 조성사업 개요

\begin{tabular}{|c|c|}
\hline 구분 & 내용 \\
\hline 사업주체 & $\begin{array}{l}\text { 문화체육관광부장관이 심의위원회의 심의를 거쳐 광역 및 기초 지자체를 문화도시 지정 } \\
- \text { 기초 지자체는 광역 지자체와 사전 협의를 거쳐 지정 신청 } \\
\text { - 문화도시지정 } n-1 \text { 에 문화도시조성계획 검토·승인을 득하여 예비사업을 추진해야 함 }\end{array}$ \\
\hline 조성내용 & $\begin{array}{l}\text { 기본분야를 설정하고 지역이 제안하는 문화브랜드를 담은 ‘문화도시조성계획' 수립 } \\
\text { - 기본 분야는 문화 관련법을 근거로 역사전통 / 예술 / 문화산업 / 사회 문화 중심형 및 지역 } \\
\text { 자율형으로 유형을 구분하고 종합 지원 } \\
\text { - 지역이 중심적으로 추진하려는 사업̌ㅜ추진전략 등을 근거로 하여 분야 선택 } \\
\text { - 문화도시조성계획 수립 시에 각 지자체는 지정신청 분야 외에 다른 분야에 속하는 사업들도 } \\
\text { 복합적으로 포함하여 도시 문화계획 차원의 종합적인 계획을 수립할 필요 }\end{array}$ \\
\hline 조성기간 & 5년 \\
\hline 조성예산 & 국비 최대 100 억원/개소(국비 50\%, 지방비 50\%) \\
\hline
\end{tabular}

15) 지역문화진흥법 제 17 조(문화도시에 대한 지원) 문화체육관광부장관은 제 15 조에 따라 지정된 문화도시에 대하여 대통령령으로 정하는 바에 따라 행정적·재정적 지원을 할 수 있음 


\section{나. 추진배경}

유럽 문화수도 사업, 유네스코 창의도시네트워크 등 지역 고유의 문화적 자산을 활용 하여 도시브랜드를 창출하고 지역 사회·경제 활성화를 모색하는 '문화도시'에 대한 세계 적 관심 지속되었다. 국내에서는 2000년대 초부터 문화특화지역 사업(도시형, 마을형) 및 지역거점 문화도시 증 정부·지방자치단체 차원에서 추진한 도시문화 관련 사업 경험 이 축척되면서 창의적이며 지속가능한 지역발전전략으로서 '문화도시'에 기대가 확산되 었다.

지역거점 문화도시를 조성하려는 계획 하에 2006년부터 전주, 경주, 공주, 부여 등을 역사전통문화도시로 추진하였고, 도시 및 지역의 특색있는 문화프로그램을 지원하는 문 화특화지역조성사업은 2014년부터 2019년까지 누적 81개소를 지원(문화도시형 36개 소 문화마을형 45개소 지원)하는 등 경험을 누적하여 왔다.

그러나 이러한 문화도시에 대한 지원은 법적근거 없이 불안정하게 추진되어오다가, 2014년 지역문화진흥법 제정으로 문화도시 지정 근거가 마련되었고 2018년부터 문화 도시 지정사업을 추진하게 되었다. 문화적 기반과 역량을 갖춘 도시를 대상으로 장기적 관점에서 문화를 통한 지역발전 계획 전반을 종합적·체계적으로 지원하며, 지역별 특색 있는 문화도시 조성으로 지역의 고유성과 정체성을 회복하고, 지역의 성장 기반이 될 것으로 기대하고 있다. 장기적으로 '모든 도시는 특별하다'는 관점 하에 지역의 자율성, 다양성, 창의성을 살리는 문화도시 지정 제도 확산을 계획하고 있다.

\section{다. 현황}

문화체육관광부는 2019년 12월에 처음으로 1차 문화도시 7곳을 지정을 시작으로 2021년 1월에는 2차 문화도시 5곳을 지정하고 현재 3차 문화도시 지정을 앞두고 있 다. 1 차 문화도시로는 경기 부천시, 강원 원주시, 충북 청주시, 충남 천안시, 경북 포항 시, 제주 서귀포시, 부산 영도구 등이 지정됐으며 2차 문화도시는 인천 부평구, 강원 춘 천시, 강원 강릉시, 전북 완주군, 경남 김해시가 지정됐다.

최종 지정된 지방자치단체에는 5 년간의 문화도시 조성 과정에 대한 행·재정적 지원, 전문가 자문 상담, 문화도시 간 교류 기회 등을 제공한다. 
〈표 3-29〉 문화도시 지정 현황

\begin{tabular}{|c|c|c|}
\hline 구분 & 지자체 & 사업명 \\
\hline \multirow{7}{*}{ 1차 } & 경기 부천시 & 생활문화도시 부천 \\
\hline & 강원 원주시 & 시민이 만들어가는 창의문화도시 원주 \\
\hline & 충북 청주시 & 기록문화 창의도시 청주 \\
\hline & 충남 천안시 & 시민의 문화자주권이 실현되는 문화독립도시 천안 \\
\hline & 경북 포항시 & 시민들의 행복한 삶을 응원하는 철학(鐵學)문화도시 포항 \\
\hline & 제주 서귀포시 & 105 개 마을이 가꾸는 노지(露地) 문화 서귀포 \\
\hline & 부산 영도구 & 예술과 도시의 섬, 영도 \\
\hline \multirow{5}{*}{ 2차 } & 인천 부평구 & 삶의 소리와 함께 내 안의 시민성이 자라는 문화도시 부평 \\
\hline & 강원 강릉시 & 아름답고, 쾌적하며, 재미있는 문화도시, 시나미 강릉 \\
\hline & 강원 춘천시 & 시민의 일상이 문화가 되고 문화적 삶이 보장되는 전환문화도시 춘천 \\
\hline & 전북 완주군 & 공동체 문화도시 완주 \\
\hline & 경남 김해시 & 오래된 미래를 꿈꾸는 역사문화도시 김해 \\
\hline
\end{tabular}

자료: 지역문화진흥원 홈페이지

\section{2. 운영방식}

\section{가. 추진절차}

문화도시 지정을 원하는 지방자치단체는 문화도시 조성계획을 수립하고 문화체육관 광부에 문화도시 지정을 신청하고, 문화체육관광부 장관은 문화도시심의위원회를 구성 하여 문화도시 조성계획을 검토 및 승인한다. 문화체육관광부 장관으로부터 문화도시 조 성계획을 승인받은 지방자치단체는 예비사업을 1 년 이상 추진하고 기간동안 전문가로 구성된 컨설팅단(문화체육관광부 기본 인력 풀 제공)의 자문을 받을 수 있다. 문화도시 조성계획 승인 1 년 후, 문화도시심의위원회는 예비사업 추진실적을 평가하여 최종적으 로 문화체육관광부 장관이 문화도시로 지정한다.

[그림 3-11] 지역문화진흥법에 따른 문화도시 지정절차

\begin{tabular}{|c|c|c|c|c|c|c|c|}
\hline 1 & $\begin{array}{l}\text { 문화도시 조성계획 수립 } \\
\text { / 문화도시 지정 신청 }\end{array}$ & \multirow[t]{2}{*}{$\triangleright$} & 2 & $\begin{array}{l}\text { 문화도시 조성계획 } \\
\text { 검토·승인 }\end{array}$ & \multirow[t]{2}{*}{$\nabla$} & \multicolumn{2}{|r|}{$\begin{array}{l}\text { 예비사업 추진 } \\
\text { (1년 이상) }\end{array}$} \\
\hline & $\begin{array}{l}\text { 지자체 신청 } \\
\text { 문체부 접수 }\end{array}$ & & \multicolumn{2}{|c|}{$\begin{array}{c}\text { 문체부장관 } \\
\text { (문화도시심의위원회 검토·승인) }\end{array}$} & & \multicolumn{2}{|c|}{$\begin{array}{c}\text { 지자체 추진 } \\
\text { (문체부 컨설팅 및 모니터링) }\end{array}$} \\
\hline 4 & $\begin{array}{l}\text { 문화도시 } \\
\text { 지정심의 }\end{array}$ & \multirow[t]{2}{*}{$\nabla$} & 5 & $\begin{array}{l}\text { 문화도시 } \\
\text { 지정 } \\
\end{array}$ & \multirow[t]{2}{*}{$\nabla$} & \multirow[t]{2}{*}{6} & $\begin{array}{c}\text { 본 사업 추진 } \\
\text { (최대 5년간 지원) } \\
\end{array}$ \\
\hline & 문화도시심의위원회 & & & 관 지정 & & & $\begin{array}{c}\text { 지자체 추진 } \\
\text { 베부 행·재정적 지원) }\end{array}$ \\
\hline
\end{tabular}

자료: 문화체육관광부(2021), 2021 문화도시 추진 가이드라인 
〈표 3-30〉 문화도시 조성계획과 문화도시지정 심의 비교

\begin{tabular}{|c|c|c|}
\hline 구분 & 문화도시 조성계획 검토 & 문화도시 지정 심의 \\
\hline 시기 & 문화도시 지정신청 후 조성계획 제출 시점 & 조성계획 승인 1년(예비사업 시행) 이후 시점 \\
\hline 행정절차 & 계획 검토 및 승인 & 지정 심의 및 지정 \\
\hline 시행주체 & 문체부 / 문화도시심의위원회 & 문체부 / 문화도시심의위원회 \\
\hline 기준 & 조성계획 검토·승인 기준 & 문화도시 지정심의 기준 \\
\hline 추진절차 & $\begin{array}{l}\text { (1) 문화도시조성계획 검토 요청 } \\
\text { (2) 조성계획 실무검토단 구성 및 운영 } \\
\text { (3) 1차 서면 검토 (계횐내용 검토) } \\
\text { (4) } 2 \text { 차 현장 검토 (현장실사 확인) } \\
\text { (5) } 3 \text { 차 발표 검토 (최종 검토/확인) } \\
\text { (6) 문화도시 조성계획 승인 }\end{array}$ & $\begin{array}{l}\text { (1) 문화도시 지정심의 요청 } \\
\text { (2) 심의위원회 소집 및 운영 } \\
\text { (3) } 1 \text { 차 서면 심사(예비사업 현황 확인) } \\
\text { (4) } 2 \text { 차 현장 실사 (현장실사 확인) } \\
\text { (5) } 3 \text { 차 발표 심사 (최종 심의/의결) } \\
\text { (6) 문화도시 지정 }\end{array}$ \\
\hline
\end{tabular}

주: 문화도시 조성계획 검토에는 실무검토단 구성·운영 예정

자료: 문화체육관광부(2021), 2021 문화도시 추진 가이드라인

\section{나. 문화도시 지정 내용}

각 지역은 문화도시를 조성하기 위해 주민 주도의 민관 협업 체계를 구성하고 다양한 세대·계층의 의견을 수렴해 지역의 고유성을 살린 문화프로그램이나 문화적 도시재생 사업 등 문화적 관점에서 지역을 발전시키는 사업 등을 직접 발굴하고 추진해야 한다. 지역 내 문화단체와 예술가, 전문가 등 다양한 이해관계의 참여를 통해 사업을 만들어가 는 상향식을 원칙으로 하고, 문화도시 지정을 위해서 지방자치단체는 문화도시 조성계획 을 수립 및 승인받고 예비사업 1년을 수행해야 한다.

각 지방자치단체의 문화도시 조성계획은 도시 고유 명칭을 바탕으로 기본분야(21년 5 개 분야)를 설정하고 지역이 신청 및 제안하는 문화브랜드를 담아 계획을 수립하도록 제시하고 있다. 기본 분야는 문화 관련법을 근거로 역사전통, 예술, 문화산업, 사회문화 중심형, 지역 자율형으로 유형을 구분하고 있으며, 각 지역이 중심적으로 추진하려는 사 업·추진전략 등을 근거로 하여 분야를 선택한다. 기본분야는 지방자치단체별 특성화된 계획의 수립과 사업 추진을 위한 기초 구분의 지침으로만 운용하며, 각 분야별 지정 도 시 수에 대한 제한을 두지 않는다. 
〈표 3-31〉 문화 도시 유형과 세부 분야

\begin{tabular}{|c|c|c|c|}
\hline 기본 분야 & & 관련법 근거 & 세부 분야(예시) \\
\hline 역사전통 중심형 & \multirow{5}{*}{$\begin{array}{l}\text { 지 } \\
\text { 역 } \\
\text { 문 } \\
\text { 화 } \\
\text { 진 } \\
\text { 흥 } \\
\text { 법 }\end{array}$} & 문화재보호법, 고도보존육성특별법 등 & 역사/전통 등 \\
\hline 예 술 중심형 & & 문화예술진흥법 등 & $\begin{array}{l}\text { 문학/미술/음악/무용/연극/ } \\
\text { /국악/사진/건축/어문 등 }\end{array}$ \\
\hline 문화산업 중심형 & & 문화산업진흥기본법 등 & $\begin{array}{l}\text { 영상/음악/게임/출판/광고/만화 } \\
\text { /대중문화예술/문화콘텐츠 등 }\end{array}$ \\
\hline 사회문화 중심형 & & $\begin{array}{c}\text { 국민여가활성화기본법, 인문학 및 } \\
\text { 인문정신문화의 진흥에 관한 법률 등 }\end{array}$ & $\begin{array}{c}\text { 생활문화/여가/인문/문화교육/ } \\
\text { 다문화/시민문화 등 }\end{array}$ \\
\hline 지 역 자 율 형 & & 문화도시 조성 관련법 일반 & $\begin{array}{l}\text { 기본분야 융·복합/생태문화 등 } \\
\text { 지역별 특성을 고려하여 제시 }\end{array}$ \\
\hline
\end{tabular}

자료: 문화체육관광부(2021), 2021 문화도시 추진 가이드라인

지난 1,2 차 문화도시를 지정한 문화체육관광부는 유관사업 간 연계·협업 영역을 확 대하여 제도를 보완해 나가고 있다. 조성계획 수립 시 도시재생뉴딜(국토교통부), 주민참 여예산제도(행정안전부) 등 다양한 부처 간 사업과 연계할 경우 연계 계획의 우수성에 따라 평가 가점을 부여하고, 예비도시를 대상으로 문화영향평가를 필수조건으로 제시하 고 있다.제4차 예비도시부터는 최종 지정 심의(2022년 하반기 예정) 전까지 문화체육관 광부가 수행하는 문화영향평가(진단평가 제외)16)를 필수적으로 완료해야 한다.

〈표 3-32〉 도시재생뉴딜사업 및 주민참여예산제도 연계방향

\begin{tabular}{|c|c|c|}
\hline 연계 사업명 & 개요 & 연계 방향 \\
\hline $\begin{array}{c}\text { 도시재생뉴딜 } \\
\text { (국토부) }\end{array}$ & $\begin{array}{l}\text { 주거환경 개선, 도시경쟁력 강화 목적 } \\
\text {. 유형별 총 50억 250억(3년 6년) 지원 } \\
\text { '18년 99곳, '19년 98곳, '20년 120곳 }\end{array}$ & $\begin{array}{l}\text { 문화도시↔뉴딜사업 상호가점 부여('19년 ) } \\
\text {. 공동 사업지역에 지자체 자율 협의체 운영 안 } \\
\text { 내('20년 ) } \\
\text { ※ 문체부-국토부 MOU('18.8월) }\end{array}$ \\
\hline $\begin{array}{l}\text { 주민참여 } \\
\text { 예산제도 } \\
\text { (행안부) }\end{array}$ & $\begin{array}{l}\text { - 주민들이 공청회, 설문조사, 사업 공모 등 다 } \\
\text { 양한 방식으로 지자체 예산편성방식에 참여 } \\
\text { ('11년 ) } \\
\text { *'18년 기준 전국 } 231 \text { 개 지자체 중 } 55 \text { 개에 } \\
\quad \text { 서(2.38\%) 문화 분야 분과위원회 운영 중 }\end{array}$ & $\begin{array}{l}\text { 문화도시 조성계획에 주민참여예산위원회 내 } \\
\text { 문화분과 설치 등 제도 활성화 계획 포함 }\end{array}$ \\
\hline
\end{tabular}

자료: 문화체육관광부(2021), 2021 문화도시 추진 가이드라인

문화도시조성계획과 문화도시지정 심의기준은 다음과 같다.

16) 문화기본법 제 5 조(국가와 지방자치단체의 책무) (4) 국가와 지방자치단체는 각종 계획과 정책을 수립할 때에 문화적 관점에서 국민의 삶의 질에 미치는 영향을 평가(이하 이 조에서 "문화영향평가"라 한다)하여 문화적 가치가 사회적으로 확산될 수 있도록 하여야 한다. 


\section{1) 문화도시 조성계획 검토, 승인 기준}

〈표 3-33〉 문화도시 조성계획 검토, 승인 기준

\begin{tabular}{|c|c|c|c|}
\hline 항목 & 세부 평가항목 & 평가지표 & 배점 \\
\hline \multirow{2}{*}{$\begin{array}{l}\text { 문화도시 } \\
\text { 추진 필요성 } \\
\text { 및 방향의 } \\
\text { 적정성 } \\
\text { (20점) }\end{array}$} & $\begin{array}{c}\text { 문화도시 } \\
\text { 추진 필요성 }\end{array}$ & $\begin{array}{l}\text { · 도시 일반현황 조사·분석 } \\
\text { · 도시 문화자원 및 유·무형자산 조사·분석 } \\
\text { (역사·문화자원, 인적자원, 문화인프라, 문화행사 등) } \\
\text { · 도시 환경 및 현황의 분석 및 진단결과 제시 }\end{array}$ & 10 \\
\hline & $\begin{array}{l}\text { 문화도시 추진 } \\
\text { 방향의 적정성 }\end{array}$ & $\begin{array}{l}\cdot \text { 비전 및 목표설정의 적절성 } \\
\cdot \text { 지역의 고유·핵심가치 제시 및 반영 } \\
\cdot \text { 문화도시정책 가치 부합 여부 }\end{array}$ & 10 \\
\hline \multirow{4}{*}{$\begin{array}{l}\text { 조성계획의 } \\
\text { 타당성 및 } \\
\text { 적정성 } \\
\text { (50점) }\end{array}$} & $\begin{array}{c}\text { 특성화 계획의 } \\
\text { 타당성 및 적정성 }\end{array}$ & $\begin{array}{l}\cdot \text { 조성계획의 타당성 및 실현가능성 } \\
\cdot \text { 지정분야별 특성화 계획의 적절성 } \\
\cdot \text { 지역의 정체성 및 고유성 확보 여부 } \\
\cdot \text {. 지역특성에 적합한 추진과정 및 방법론 제시 여부 }\end{array}$ & 15 \\
\hline & $\begin{array}{l}\text { 지역 활성화 } \\
\text { 기대효과 }\end{array}$ & $\begin{array}{l}\text { · 문화 기반의 지역 문화·사회·경제 활성화 및 효과 } \\
\text { · 도시의 브랜드 및 지역의 문화경쟁력 확보 } \\
\text { · 기타 공동체 활성화 방안 }\end{array}$ & 15 \\
\hline & $\begin{array}{l}\text { 사회참여 및 } \\
\text { 소통 방안 }\end{array}$ & $\begin{array}{l}\cdot \text { 도시민의 문화 참여 및 접근성 보장여부 } \\
\cdot \text { 다양한 주체의 참여기회 보장 및 활동지원 } \\
\cdot \text { 문화소외지역 및 취약계층의 문화접근성 확보 }\end{array}$ & 15 \\
\hline & $\begin{array}{c}\text { 정책 및 사업 } \\
\text { 연계·협력 가능성 }\end{array}$ & $\begin{array}{l}\text { · 지자체 간, 광역-기초 간 협력방안 제시 여부 } \\
\text { · 관련 타 사업 및 기관과의 연계 및 협업방안 } \\
\text { (도시재생뉴딜(국토부), 관광거점도시(문체부) 등) } \\
\text { · 예산, 조직(인력), 정책적 협력방안 구축 여부 } \\
\quad \text { (예산 지원, 협의체 구성, } \mathrm{MOU} \text { 체결 계획 등) } \\
\text { · 협업·연계의 구체성 및 실현가능성 }\end{array}$ & 5 \\
\hline \multirow{3}{*}{$\begin{array}{l}\text { 문화도시 } \\
\text { 실현가능성 } \\
\text { (30점) }\end{array}$} & 추진체계 구축 & $\begin{array}{l}\text { · 추진체계의 규모, 조직, 역할의 적절성 } \\
\text { · 추진조직의 독립성, 인력의 전문성, 운영의 안정성 } \\
\text { · 시민·공공전문가 등의 거버넌스 구축계획 및 적절성 }\end{array}$ & 10 \\
\hline & $\begin{array}{c}\text { 정책지원 및 } \\
\text { 재원계획의 합리성 }\end{array}$ & $\begin{array}{l}\text { · 지자체의 정책 및 사업계획에의 반영 여부 } \\
\text { · 관련 조례 제정 등 제도적 기반 확보계획 } \\
\text { · 예산확보 및 재정투입계획의 적절성, 합리성 }\end{array}$ & 10 \\
\hline & $\begin{array}{c}\text { 문화도시 지속가능성 } \\
\text { 확보방안 }\end{array}$ & $\begin{array}{l}\text { · 자체 모니터링·환류시스템 구축여부 및 적절성 } \\
\text { · 중장기 발전계획 수립 여부 및 합리성 } \\
\text { · 국비지원 이후, 기타 지속가능성 확보 방안 제시 } \\
\text { (재원확보 및 투입계획, 인력·조직 등) }\end{array}$ & 10 \\
\hline \multirow[t]{2}{*}{$\begin{array}{l}\text { 문화를 통한 } \\
\text { 균형발전 } \\
\text { 견인 가능성 } \\
\quad \text { (+2점) }\end{array}$} & $\begin{array}{l}\text { 국토 균형 발전을 } \\
\text { 위하여 } \\
\text { 문화취약지역에 대한 } \\
\text { 정책적 고려 }\end{array}$ & - 성장촉진지역(70개소) 등에 해당할 경우 가점 부여 & +2 \\
\hline & 합 계 & & $100+2$ \\
\hline
\end{tabular}

자료: 문화체육관광부(2021), 2021 문화도시 추진 가이드라인 


\section{2) 문화도시 지정 심의 기준}

〈표 3-34〉 문화도시 지정심의 기준

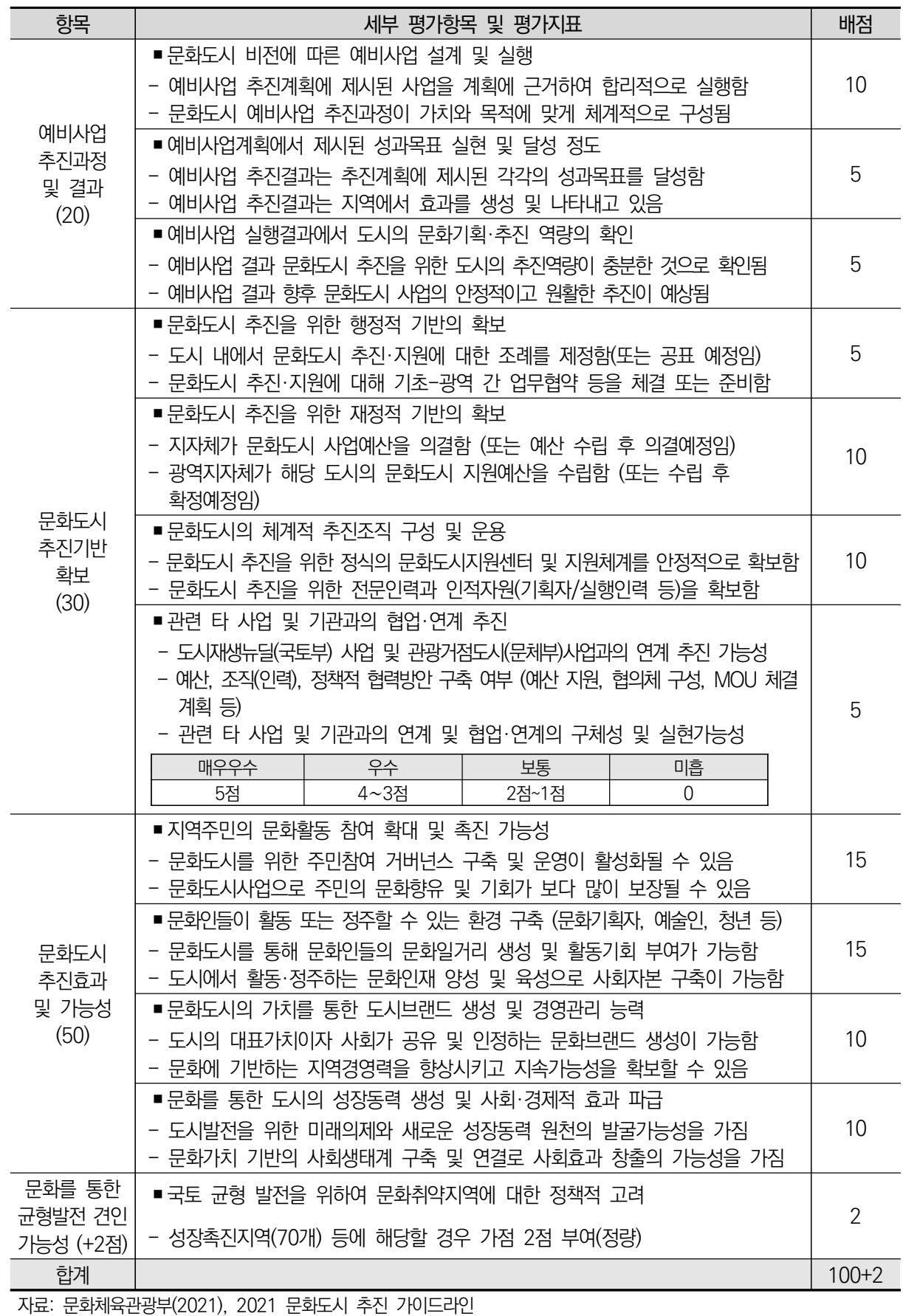




\section{다. 성과평가}

\section{1) 평가방향 및 활용}

2019년 12월 1차 문화도시 7개 지정, 2020년 말 1차 문화도시 사업 성과평가가 진 행되었다. 평가는 문화도시 운영성과를 체계적으로 평가하여 성과에 대한 책임성 확보하 기 위하여 문제점 분석 및 개선방향 모색에 방점을 두고, 성과확산을 도모하되 지나친 경쟁이나 서열화는 지양하고자 설계되었다. 평가결과에 따라 우수한 지방자치단체는 연 차별 전체 예산 중 일부는 기본 사업비로 책정하고, 추가 인센티브 사업비를 분할 지급 하였다. ' 20 년 지정된 문화도시 당 $1,285.7$ 백만원을 균등지급하였고, 평가결과에 따라 3 등급으로 구분하여 ' 21 년 예산을 차등지급하였다. '21년 예산은 기본사업비를 도시별 14 억으로 배정하고, 인센티브 사업비를 3개의 그룹으로 나누어 A그룹(2개)에는 2억, B 그룹(3개)에는 1 억을 추가 지급하고 C그룹(2개)은 인센티브 예산을 배정하지 않았다.

\section{2) 평가체계}

각 문화도시에 대한 평가는 거버넌스 지표에 대한 평가(65점)와 성과 지표에 대한 평 가(35점)로 구분된다. 거버넌스(65점)와 공통성과 지표(5점)의 각 배점항목은 모든 지방 자치단체에 대하여 공통적으로 적용되며 고유성과(30점)의 평가 지표는 문화진흥(15 점), 지역발전(15점)의 배점 내에서 지방자치단체별로 자율적으로 구성한다. 성과지표는 연차별 거버넌스와 성과 영역별 가중치를 조정하여 점차 성과의 비중을 높여가는 방식 을 적용한다. 다만 거버넌스의 지속성이 갖는 중요성을 고려하여 사업 후반기에도 거버 넌스의 비중 일정정도로 유지할 계획이다.

〈표 3-35〉 문화도시 성과평가 연차별 가중치 조정 계획

\begin{tabular}{c|c|c|c|c|c}
\hline 영역 & 1년차 & 2년차 & 3년차 & 4년차 & 5년차 \\
\hline 거버넌스 & 65 & 60 & 50 & 50 & 50 \\
\hline 성과 & 35 & 40 & 50 & 50 & 50 \\
\hline
\end{tabular}

평가 절차는 문화체육관광부에서 심의위원을 구성하고 도시별 작성한 성과보고서를 2차에 걸쳐 평가하고 최종적으로 심의위원회에서 종합 평정한다. 심의위원은 당연직 2 인을 제외한 총 16 명으로 구성하고, 심의위원별 거버넌스영역과 성과영역, 모든영역 평 가로 구분하여 평가를 진행한다. 


\section{3) 평가지표}

〈표 3-36〉 문화도시 성과평가 지표

\begin{tabular}{|c|c|c|c|c|}
\hline 영역 & $\begin{array}{l}\text { 중분류 } \\
\text { (배점) }\end{array}$ & $\begin{array}{c}\text { 지표 } \\
\text { (배점) }\end{array}$ & 지표 정의 & 세부지표 예시 \\
\hline \multirow{7}{*}{$\begin{array}{l}\text { 거버 } \\
\text { 넌스 } \\
\text { (65) }\end{array}$} & \multirow{2}{*}{$\begin{array}{l}\text { 1. 비전과 } \\
\text { 전략 } \\
\text { (10) }\end{array}$} & $\begin{array}{c}\text { 비전공유 } \\
\text { (5) }\end{array}$ & $\begin{array}{l}\text { 문화도시 비전을 보다 많은 } \\
\text { 시민과 효과적으로 공유하 } \\
\text { 여 문화민주주의 기반을 } \\
\text { 확대하기 위한 노력 }\end{array}$ & $\begin{array}{l}\text { (정성) 비전 제시의 효과성 } \\
\text { (정성) 비전 공감을 위한 소통 노력 } \\
\text { (정량) 비전 소통 실적 } \\
\text { (정량) 문화도시 인지도 } \\
\text { (정량) 비전 공감 정도 }\end{array}$ \\
\hline & & $\begin{array}{l}\text { 전략적 } \\
\text { 접근 } \\
(5)\end{array}$ & $\begin{array}{l}\text { 조성계획과 환경변화를 } \\
\text { 종합적으로 고려하여 문화 } \\
\text { 도시 비전 실현을 위한 } \\
\text { 전략을 구체화하고 지속성 } \\
\text { 을 확보하기 위한 노력 }\end{array}$ & $\begin{array}{l}\text { (정성) 실천전략의 구체화 } \\
\text { (정량) 실천전략의 지속성 }\end{array}$ \\
\hline & \multirow{3}{*}{$\begin{array}{l}\text { 2. 추진기반 } \\
\text { (30) }\end{array}$} & $\begin{array}{l}\text { 거버넌스 } \\
\text { 구축 } \\
(10)\end{array}$ & $\begin{array}{l}\text { 문화도시를 시민 중심으로 } \\
\text { 추진하기 위한 다양한 주체 } \\
\text { 들의 체계적인 논의와 협의 } \\
\text { 구조 발전을 위한 노력 }\end{array}$ & $\begin{array}{l}\text { (정성) 거버넌스 강화 노력 } \\
\text { (정성) 시민참여 제고 노력 } \\
\text { (정량) 문화도시추진위원회 개최 } \\
\text { (정량) 문화도시 시민참여율 } \\
\text { (정량) 문화도시 재정민주주의 수준 }\end{array}$ \\
\hline & & $\begin{array}{l}\text { 사업 } \\
\text { 추진역량 } \\
\text { 강화 } \\
\text { (10) }\end{array}$ & $\begin{array}{l}\text { 사업 추진주체의 자율성을 } \\
\text { 바탕으로 한 역량 강화와 } \\
\text { 지자체 행정역량 강화 }\end{array}$ & $\begin{array}{l}\text { (정성) 사업 추진주체 자율성 확보 } \\
\text { (정성) 사업 추진주체 인력의 역량 강화 } \\
\text { (정성) 지자체 행정역량 강화 } \\
\text { (정량) 사업 추진주체 인력의 연수·교육 } \\
\text { (정량) 사업 추진주체 인력의 근속연수 }\end{array}$ \\
\hline & & $\begin{array}{l}\text { 협력과 } \\
\text { 네트워크 } \\
(10)\end{array}$ & $\begin{array}{l}\text { 다른 정책 주체 및 도시와의 } \\
\text { 협력을 통한 문화도시 } \\
\text { 발전의 노력 }\end{array}$ & $\begin{array}{l}\text { (정성) 다른 정책 주체와의 협력 } \\
\text { (정성) 다른 도시와의 협력 } \\
\text { (정량) 협력사업 및 협력프로그램 수 } \\
\text { (정량) 문화도시 상생협의체 참여 횟수 }\end{array}$ \\
\hline & \multirow[t]{2}{*}{$\begin{array}{l}\text { 3. 자율관리 } \\
\text { (25) }\end{array}$} & $\begin{array}{l}\text { 여건 } \\
\text { 조성과 } \\
\text { 사업 수행 } \\
\text { (10) }\end{array}$ & $\begin{array}{l}\text { 문화도시 수행을 위한 } \\
\text { 법제도 환경 조성 및 } \\
\text { 재원확보, 지자체 행정지원 } \\
\text { 을 통한 여건 조성과 } \\
\text { 사업 수행을 위한 적정성 및 } \\
\text { 윤리성, 갈등관리 노력 }\end{array}$ & $\begin{array}{l}\text { (정성) 법·제도 환경 조성 및 재원확보 } \\
\text { (정성) 개별 사업 수행의 적정성 및 윤리 } \\
\text { 성 } \\
\text { (정성) 지자체 행정지원의 적정성 } \\
\text { (정성) 갈등관리 노력 } \\
\text { (정량) 재원조성 } \\
\text { (정량) 목표 달성 사업 비율 } \\
\text { (정량) 예산집행률 }\end{array}$ \\
\hline & & $\begin{array}{l}\text { 자체 } \\
\text { 성과관리 } \\
\text { 체계운영 } \\
\text { 의 적절성 } \\
\quad(15) \\
\end{array}$ & $\begin{array}{l}\text { 문화도시 고유성과를 } \\
\text { 자율적으로 관리하기 위한 } \\
\text { 운영체계와 모니터링을 } \\
\text { 적정하게 운영하고 시민과 } \\
\text { 결과를 공유하는 노력 }\end{array}$ & $\begin{array}{l}\text { (정성) 자체성과관리의 충실성 } \\
\text { (정성) 모니터링 운영 및 결과 공유의 적 } \\
\text { 정성 } \\
\text { (정성) 환류 활동 } \\
\text { (정량) 모니터링 수행 정도 }\end{array}$ \\
\hline $\begin{array}{l}\text { 성과 } \\
\text { (35) }\end{array}$ & $\begin{array}{l}\text { 4, 고유성과 } \\
\text { (30) }\end{array}$ & $\begin{array}{l}\text { 문화진흥 } \\
\text { (15) }\end{array}$ & $\begin{array}{l}\text { 문화예술생태계 조성, 문화 } \\
\text { 활동 참여 증대, 지역문화 } \\
\text { 발전, 문화공간 강화 등의 }\end{array}$ & $\begin{array}{l}\text { 세부지표와 가중치는 자율 구성 } \\
\text { * 성과관리 가이드라인에 예시 포함 }\end{array}$ \\
\hline
\end{tabular}




\begin{tabular}{|c|c|c|c|c|}
\hline 영역 & $\begin{array}{l}\text { 중분류 } \\
\text { (배점) }\end{array}$ & $\begin{array}{c}\text { 지표 } \\
\text { (배점) }\end{array}$ & 지표 정의 & 세부지표 예시 \\
\hline & & & $\begin{array}{l}\text { 문화진흥 성과 관리를 위한 } \\
\text { 지자체 자율 지표 설정 및 } \\
\text { 지표 달성 내용 }\end{array}$ & \\
\hline & & $\begin{array}{l}\text { 지역발전 } \\
\text { (15) }\end{array}$ & $\begin{array}{l}\text { 지속가능한 성장, 포용적 } \\
\text { 지역사회, 도시브랜딩 강화, } \\
\text { 도시공간 발전 등의 } \\
\text { 지역발전 성과 관리를 위한 } \\
\text { 자체 자율 지표 설정 및 } \\
\text { 지표 달성 내용 }\end{array}$ & $\begin{array}{l}\text { 세부지표와 가중치는 자율 구성 } \\
\text { * 성과관리 가이드라인에 예시 포함 }\end{array}$ \\
\hline & \multirow{2}{*}{$\begin{array}{l}\text { 5. 공통성과 } \\
\text { (5) }\end{array}$} & $\begin{array}{l}\text { 대표사업 } \\
\text { 참여자 } \\
\text { 만족도 } \\
\text { (2) }\end{array}$ & $\begin{array}{l}\text { 문화도시별 대표사업 } 3 \text { 개 } \\
\text { 참여자 대상 만족도 조사 }\end{array}$ & $\begin{array}{l}\text { (정량) 문화도시별로 } 3 \text { 개 대표사업 선정 } \\
\text { 하여 대표사업별 참여인원 규모를 반영 } \\
\text { 한 가중표본을 할당하여 수혜자 대상 } \\
\text { 온·오프라인 조사 }\end{array}$ \\
\hline & & $\begin{array}{l}\text { 문화도시 } \\
\text { 정체성 } \\
\text { (3) }\end{array}$ & $\begin{array}{l}\text { 문화도시 이미지와 } \\
\text { 정체성의 창출 수준 }\end{array}$ & $\begin{array}{l}\text { (정량) 문화도시 이미지와 정체성의 창출 } \\
\text { 수준 }\end{array}$ \\
\hline
\end{tabular}

자료: 문화체육관광부(2021), 2021 문화도시 추진 가이드라인 


\section{제5절 시사점}

앞서 지방자치단체에서 계획을 수립하고 계획에 대한 포괄적 형태의 예산을 보조하는 포괄보조방식의 사례를 살펴보았다. 농림축산식품부의 농촌협약, 보건복지부의 지역자 율형 사회서비스투자사업과 지역사회 통합건강증진사업, 문화체육관광부의 문화도시조 성사업의 보조금 지원방식과 성과관리체계를 중점 검토하였고, 성과관리에 관한 시사점 을 도출하면 다음과 같다.

(1) 유관계획 간 연계, 조직체계 등 전제조건, 지자체 사업구상 자율성 제약 유의

포괄보조 방식의 사업들은 계획단계에서 상당히 체계적이고 구체적인 계획서가 요구되 고, 사업의 종류, 예산의 용도 등에 전제조건이 요구되고 있었다. 협약 혹은 포괄보조형 사 업 대상계획에 기존 계획과의 연계, 거버넌스 구축 등의 선결조건을 제시하고 있는 것이다.

농림축산식품부의 농촌협약은 전략계획 및 활성화계획을 제출하고, '농촌생활권 활성 화 계획'을 대상으로 협약을 체결하는데, 기존계획과 연계하고 협약 전담조직을 운영하 는 것을 전제조건으로 두고 있다. 협약대상 계획은 지역의 중장기 비전에 기반하여 구성 하고, 농림축산식품부의 농촌분야 지원사업 및 지방이양사업과 연계하여 기획되어야 하 는데, 반드시 마을만들기 사업을 포함한 지방이양 사업 추진계획, 농발계획, 농촌재생뉴 딜사업 연계한 계획을 수립해야 한다. 보건복지부의 지역자율형사회서비스투자 사업과 지역사회통합건강증진사업도 사업특성과 범위, 추진원칙, 제공인력 및 제공조직 등에 대 한 포괄적인 지침에 따라 계획하도록 되어있다. 문화체육관광부의 문화도시 조성계획도 역사전통, 예술, 문화산업, 사회문화 중심형, 지역 자율형 등 5 개 기본분야 중에서 하나 를 지역에서 선택하여 문화브랜드를 담아 계획을 수립하도록 사업분야를 정하고 있다. 그리고 계획 수립 시 도시재생뉴딜(국토교통부), 주민참여예산제도(행정안전부) 등 타 부 처 사업과 연계하면 가점을 부여하고 문화영향평가를 필수조건(예비도시 대상)으로 제시 하고 있다. 
더불어 농촌협약은 시군 및 시도에 협약을 담당하는 전담조직(부서)을 두고, 협약 당 사자 등으로 구성된 농촌협약 위원회를 조직하며, 농촌협약 이행을 지원하는 중간지원조 직을 운영해야 한다. 지역사회통합건강증진사업 지방자치단체 보건소에서 다양한 건강 증진 사업 분야에서 지역 여건에 따라 단위사업을 자율적으로 기획·추진한다. 문화도시 사업은 전담조직을 반드시 구성해야 하지만, 조직구성이나 운영방식은 지역 실정에 맞게 활용하도록 되어있다.

지방자치단체 면담을 통해 확인된 의견 중에는 포괄보조 방식으로 사업을 추진한다고 하지만 전제조건을 두고 예산사용 제한을 두고 있어 사업기획 재량은 제한적이고 오히 려 포괄보조 방식 가이드라인에 따른 추가적 행정업무 부담으로 인한 비판적 의견도 있 었다. 계획수립의 전제조건과 예산용도의 제약조건이 너무 상세하게 설계되어 있어 사업 선택권에 제약이 있어, 기존의 개별보조사업보다 행정력은 많이 소요되지만 개별사업 추 진과 다를 바 없다는 의견이다. 2013년부터 포괄보조형 사업을 추진한 복지부의 통합건 강증진사업은 이러한 지역의 사업선택권 제한, 자율성 저해, 사업 간 유기적 연계성 부족 등의 한계로 필수사업, 우선사업 등의 제한조건을 삭제하였다.

(2) 중앙-지자체 간 공동의 성과목표, 결과지향적 설정 중요

사업계획 수립단계에서 지방자치단체 정책의 장.단기 목표를 구체화하도록 성과목표 와 지표설정을 면밀히 검토하도록 요구하고 있고, 중앙정부 정책목표와의 지방자치단체 의 사업목표를 일치시키고자 하는 성과관리 체계를 마련하고 있다. 중앙정부와 지방자치 단체가 공동의 목표달성을 위해 노력하는 동시에 지역별 다양한 특성을 고려하여 주민 욕구와 연계되는 사업을 개발하도록 지역사회의 현황, 주민요구도 등을 반영한 계획과 목표지표를 설정하도록 요구하고 있다.

농림축산식품부의 농촌협약은 생활권에 대한 분석을 바탕으로 지역의 중장기 발전을 위한 비전, 목표, 향후 개선방향 등을 포함한 '농촌공간 전략계획'을 수립하고, 전략계획을 바탕으로 각 생활권별로 구체적인 추진과제를 담은 '농촌생활권 활성화 계획'을 수립해야 한다. 보건복지부의 지역사회통합건강증진사업은 단기적인 사업성과 뿐 아니라 지역의 보건환경 변화에 대응하여 지역사회 건강수준 향상 및 건강격차 감소를 위한 목표관리를 시행하고 있다. 성과목표는 중앙에서 제시하는 16 개 결과지표 중에서 선택하는 핵심성과 목표(국민건강증진종합계획 연관지표)와 시도 및 시·군·구에서 세부 사업별로 자율적으로 
작성하는 자체성과목표로 구분된다. 핵심성과지표는 건강생활실천과 만성질환 예방·관리 측면에서 행태 변화를 측정하는 내용으로 흡연률, 음주율, 혈압.혈당수치 인지율 등 16 개 항목이 있다. 문화체육관광부의 문화도시조성사업은 모든 지방자치단체에 공통적으로 적 용되는 거버넌스(65점)와 공통성과 지표(5점)가 있고, 지방자치단체 실정에 맞춰 자율적으 로 성과지표를 구성하는 고유성과(30점)가 있다. 고유성과 지표는 문화진흥(15점), 지역발 전(15점)의 배점 내에서 지방자치단체별로 자율적으로 구성한다. 공통성과 지표는 대표사 업 참여자 만족도, 문화도시 정체성이다.

중앙정부와 지방자치단체 간 공동의 성과목표를 나타내는 핵심지표 혹은 공통지표를 살펴보면, 포괄보조형 사업과 관련된 국가의 비전 및 목표를 고려하면서 목표를 구체화 하고 결과지향적으로 성과를 관리하고자 노력하고 있는 것으로 보인다. 다만 문화도시가 설정한 참여자 만족도, 문화도시 정체성과 같은 지표는 개별사업에 대한 산출지표의 형 식이자 상당히 주관성이 개입되는 한계가 있다. 이는 문화도시의 추진비전이 '문화를 통 한 지속가능한 지역발전 및 지역주민의 문화적 삶 확산 으로, 문화적 삶에 대한 성과를 설정하는 것이 쉽지 않고, 문화와 지역발전 간의 인과성을 밝히기 곤란한 문제 때문으로 보인다. 그러나 성과지표가 측정방식, 성과기간, 포괄범위 등에 불충분성이 크게 되면 평가결과를 신뢰하기 어렵게 되고, 이는 지방자치단체에 재정 재량권을 부여하면서도 과 정에 대한 통제는 강화되게 된다. 포괄보조 사업이 지역의 자율성과 책임성을 확보하는 순기능을 발휘하기 위해서는, 적합한 성과지표를 발굴·제공하고 성과정보의 측정과 관 리가 가능한 성과관리 체계를 정립할 필요가 있다.

(3) 계획수립부터 관리·운영까지 단계별 컨설팅을 지원, 시도 평가역량 관리 전통적인 방식의 개별 국고보조사업은 중앙정부가 설계한 표준 지침을 지방자치단체가 단순 수용하는 방식으로 진행되어, 그동안 지방자치단체 단위의 자체 전략계획을 수립·운 영할 역량이 축적되지 못하였다. 이에 포괄보조형 사업 사례들은 지방자치단체의 사업 계획 및 운영 역량을 개발하고 중앙정부와 지방자치단체의 성과목표를 일치시키기 위해 계획수립 단계부터 운영까지 컨설팅을 적극 지원하는 방식을 취하고 있다. 농촌협약, 문 화도시 사업과 같이 기획적 성격의 사업은 계획수립 단계부터 지역사회 내 의제와 핵심사 업을 발굴하기 위해 전문가 컨설팅을 권고하고 있다, 특히 중기기간의 포괄예산을 승인하 기까지 예비사업 기간을 두어 상당한 기간을 두고 지방자치단체로부터 사업대상, 자금의 
사용, 관리계획 등을 수정·보완하도록 하고 있다. 그리고 사업계획이 승인된 이후에도 사업의 질적 수준을 높이기 위해 일회성 자문이 아닌 컨설팅단을 투입하여 사업 전 과정 에 지속적이고 체계적인 사업운영을 지원하고 있다. 보건복지부의 지역자율형 사회서비 스투자사업과 지역사회 통합건강증진사업은 시도 및 군·구 중심의 주체적 성과관리 체계 를 운영하고 있다.

(4) 중앙정부의 조직 및 업무방식 일원화 중요

포괄보조형 사업 사례들은 중앙정부의 총괄부서 관장과 지방자치단체의 전담조직을 중요시하고 있었으며, 이를위해 중앙정부의 업무를 개편하고, 지방자치단체 내 전담조직 설치를 계획의 전제조건으로 두는 등의 조치를 취하고 있었다. 그런데 이러한 방식 개편 노력에도 불구하고 중앙정부 조직의 업무운영방식이 실질적으로 변화하지 않으면 결국 기존의 사업운영 지침에 의해 개별사업과 별반 다를바 없는 방식으로 진행되는 한계를 보이고 있었다. 보건복지부의 지역자율형 사회서비스투자사업. 지역사회 통합건강증진 사업은 포괄보조형 사업으로 진행되기 이전, 각각 3 개 내역사업과 13 개 사업영역으로 구분되어 중앙정부 개별부서에서 추진하던 사업을 총괄부서 관장으로 개편하였다. 그런 데 이 두 사업은 외형적으로는 포괄보조 방식을 표방하고 총괄부서 관장으로 변화하였 지만, 이전의 내역사업 및 사업영역에 있는 운영지침은 그대로 유지하고 있다. 이렇다보 니 지역단위에서 사업 우선순위를 반영한 계획 수립은 불가능하고, 실질적인 변화는 기 대하기 어려운 구조이다. 특히 산모신생아도우미사업의 경우에는 보건소를 중심으로 한 운영체계를 갖추고 있는 경우가 있는데, 다른 두 사업과 집행체계가 달라 독립적인 별개 의 사업처럼 운영되고 있어 사업조정이 더욱 제한적이다.

아울러 지방자치단체의 회계집행 방식이 기존 조직과 업무 운영방식을 준용하고 있을 경우, 더더욱 포괄보조의 효율성이나 효과성이 드러나기 어렵기 때문에 지방자치단체 회계구조가 포괄보조방식과 연동될 수 있도록 충분한 업무협의가 전제되어야 한다. 따라 서 문화분야 포괄보조방식의 도입을 위해서는 우선 포괄보조 도입을 검토하는 개별 사 업간 통합은 물론, 연계·협력 및 총괄 조정기능을 담당할 수 있는 조직체 또는 협의체가 사전적으로 마련되어야 할 것으로 판단된다. 

지역문화 성과협약형 포괄보조방식 도입방안 연구

제4장

지역문화 성과협약형

포괄보조 가능성 진단 



\section{제1절 지역문화 정책 추진현황 검토}

\section{1. 문화체육관광부 지역문화정책 추진체계 진단}

\section{가. 문화체육관광부 업무계획}

지역문화 성과협약형 포괄보조 방식을 적용하기 위해서는 중앙정부의 지역문화정책 비전과 지방자치단체의 문화정책 성과관리체계가 유기적으로 연계 가능한 영역을 확인 해야 한다. 이를 위해 먼저 문화정책 주무부처인 문화체육관광부의 지역문화정책 비전과 성과목표를 파악하였다.

[그림 4-1] 2021년 문화체육관광부의 비전-전략체계

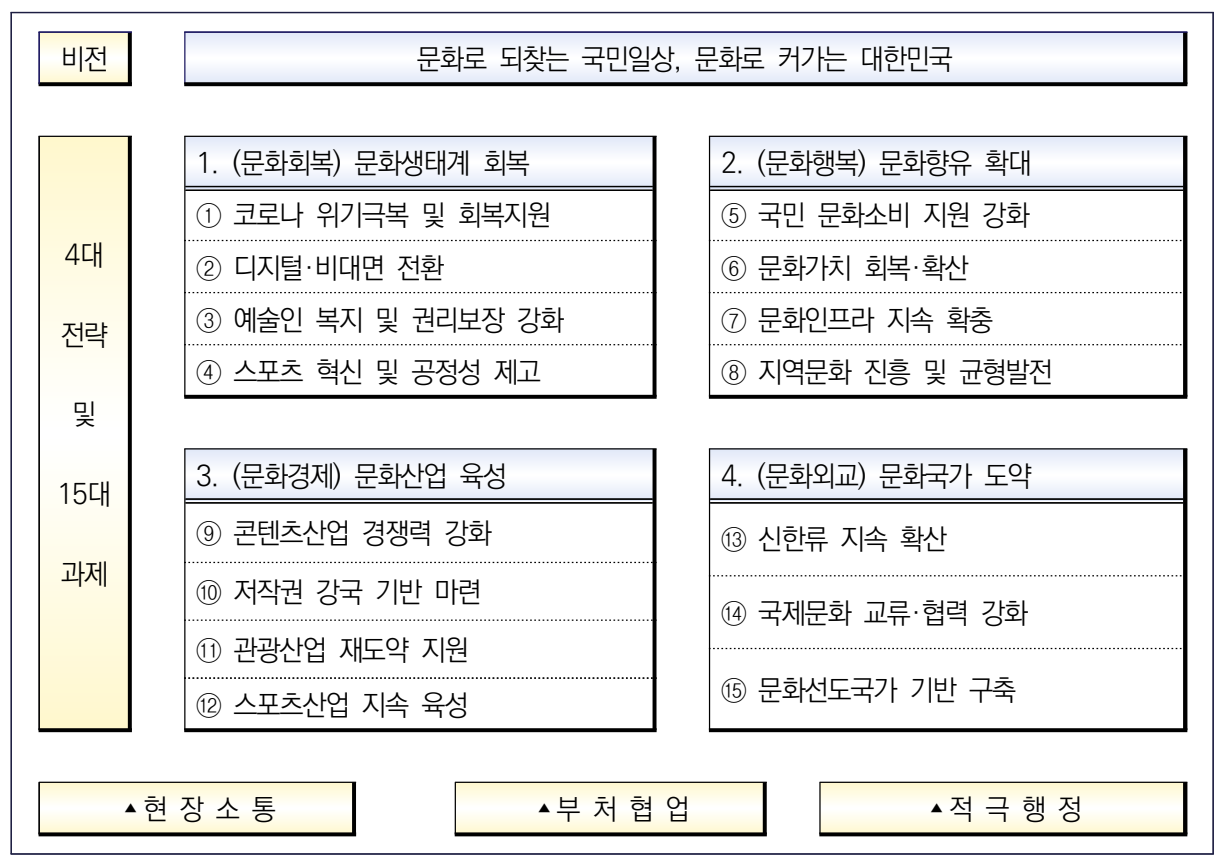

자료: 문화체육관광부(2021), 2021년도 업무계획. 
2021년 문화체육관광부 업무계획에서 비전은 '문화로 되찾는 국민일상, 문화로 커가 는 대한민국'이고 이를 추진하기 위한 4대 전략 15 대 과제 중 2-8번 전략에 '지역문화 진흥 및 균형발전'을 명시하고 있다. 과제를 실천하기 위한 사업은 지역문화 진흥 제도 화와 문화도시, 관광거점도시, 아시아문화중심도시에 대한 내용으로 지역문화정책관의 업무범위와는 약간의 차이가 있다.

동 계획의 관리지표는 11 개가 있는데, 이 중 지역문화진흥과 관련된 지표는 2 개가 있 다. 지역규모별 문화향유 격차 축소(대도시-읍면 문화예술 관람률 격차)와 박물관·도서 관 등 문화기반시설 56개 증가이다. 구체적으로 대도시-읍면 문화예술 관람률을 차이를 '20년 $17 \% \mathrm{p}$ 에서 '21년 $13 \% \mathrm{p}$ 로 줄이고자 한다. 이는 제 2 차 지역문화진흥기본계획 (2020-2024)에서 정한 2개 성과목표 중 하나와 같다. 그리고 박물관·도서관 등 문화기 반시설 '20년 3,017개에서 '21년 3,073개로 56개 늘리려는 계획이다.

〈표 4-1〉 2021년 문화체육관광부 업무계획 상 관리지표

\begin{tabular}{|c|c|}
\hline 구분 & 내용 \\
\hline \multirow{4}{*}{ 국민의 문화향유 } & $\begin{array}{l}\text { 문화예술 향유자 증가 (문화예술 관람률) } \\
(' 19 \text { 년 } 81.8 \%) \Rightarrow \text { '20년 } 60.5 \% \Rightarrow \text { '21년 81.8\% }\end{array}$ \\
\hline & $\begin{array}{l}\text { 지역규모별 문화향유 격차 축소 (대도시-읍면 문화예술 관람률 격차) } \\
\text { ('19년 } 12.7 \% p) \Rightarrow \text { '20년 } 17 \% p \Rightarrow \text { '21년 } 13 \% p\end{array}$ \\
\hline & $\begin{array}{l}\text { 1인당 국내여행일수 증가 } \\
\text { ('19년 13일) } \Rightarrow \text { '20년 7.6일(잠정) } \Rightarrow \text { '21년 12.9일 }\end{array}$ \\
\hline & $\begin{array}{l}\text { 생활체육 참여자 증가 (생활체육 참여율) } \\
(' 19 \text { 년 } 66.6 \%) \Rightarrow \text { '20년 } 60.1 \% \Rightarrow \text { '21년 } 65 \%\end{array}$ \\
\hline \multirow{2}{*}{ 생활밀착형 문화기반시설 } & $\begin{array}{l}\text { 박물관·도서관 등 문화기반시설 } 56 \text { 개 증가 } \\
\text { ('19년 2,825개) } \Rightarrow \text { '20년 } 3,017 \text { 개 } \Rightarrow 21 \text { 년 } 3,073 \text { 개 }\end{array}$ \\
\hline & $\begin{array}{l}\text { 공공체육시설 수 } 1,200 \text { 개 증가 } \\
\text { ('19년 } 28,537 \text { 개) } \Rightarrow \text { '20년 } 30,185 \text { 개 } \Rightarrow \text { '21년 31,385개 }\end{array}$ \\
\hline \multirow{5}{*}{ 콘텐츠·스포츠.관광 산업 } & $\begin{array}{l}\text { 콘텐츠 수출 8.1억달러 증가 } \\
(' 19 \text { 년 103.9억달러) } \Rightarrow \text { '20년 108.9억달러(잠정) } \Rightarrow \text { '21년 117억달러 }\end{array}$ \\
\hline & $\begin{array}{l}\text { 콘텐츠산업 매출액 4.8조원 증가 } \\
\text { ('19년 125.4조원) } \Rightarrow \text { '20년 123.2조원(잠정) } \Rightarrow \text { '21년 128조원 }\end{array}$ \\
\hline & $\begin{array}{l}\text { 관광산업 매출액 1.3조원 증가 } \\
\text { ('19년 26.8조원) } \Rightarrow \text { '20년 10.2조원(잠정) } \Rightarrow \text { '21년 11.5조원 }\end{array}$ \\
\hline & $\begin{array}{l}\text { 스포츠 산업 종사자 2만명 증가 } \\
\text { ('19년 44.9만명) } \Rightarrow \text { '20년 40.9만명(잠정) } \Rightarrow \text { '21년 42.9만명 }\end{array}$ \\
\hline & $\begin{array}{l}\text { 스포츠 산업 매출액 15.3조원 증가 } \\
\text { ('19년 } 80.6 \text { 조원) } \Rightarrow \text { '20년 50.1조원(잠정) } \Rightarrow \text { '21년 65.4조원 }\end{array}$ \\
\hline
\end{tabular}

자료: 문화체육관광부(2021), 2021년도 업무계획. 


\section{나. 문화체육관광부 성과관리계획}

2021년 문화체육관광부 성과관리계획서에서 지역문화와 관련된 내용은 '전략목표 I 삶의 질을 높이는 국민문화 환경 조성' 하부의 프로그램 목표 '1-2 지역문화 균형발전 및 생활 속 문화향유 기회 확대'으로 설정되어 있다. 해당 프로그램은 지역문화정책관 소관 사업들로 구성되어 있으며, 도서관·박물관 정책 활성화, 지역문화진흥, 문화시설 확충, 문화도시 조성, 시각예술진흥기반 구축 등이다.

〈표 4-2〉 문체부 성과계획서 전략목표1의 프로그램 체계

\begin{tabular}{|c|c|c|c|}
\hline 프로그램명 & 단위사업명 & 과제코드 & 비고 \\
\hline \multicolumn{4}{|c|}{ 전략목표 I. 삶의 질을 높이는 국민문화환경을 조성한다 } \\
\hline \multicolumn{4}{|c|}{ 프로그램목표 |-1. 창의적 문화정책 구현을 통한 국민 문화향유 기회 확대 } \\
\hline \multirow{4}{*}{$\begin{array}{l}\text { 창의적문화정책 } \\
\text { 구현 }\end{array}$} & (1) 문화-인문 진흥 & |-1-재정(1) & \\
\hline & (2) 국어문화진흥 & ।-1-재정(2) & 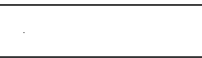 \\
\hline & (3) 전통문화 진흥 & I-1-재정(3) & \\
\hline & (4) 국제문화교류 & ।-1-재정(4) & 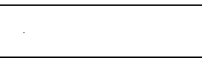 \\
\hline \multicolumn{4}{|c|}{ 프로그램목표 |-2. 지역문화 균형발전 및 생활 속 문화향유 기회 확대 } \\
\hline \multirow{8}{*}{$\begin{array}{l}\text { 지역문화 진흥 } \\
\text { 및 문화기반 } \\
\text { 조성 }\end{array}$} & (1) 도서관정보·정책 체계 활성화 & ।-2-재정(1) & 조세지출 병행 \\
\hline & (2) 박물관 정책 활성화 & ।-2-재정(2) & 조세지출 병행 \\
\hline & (3) 지역문화 진흥 & |-2-재정(3) & $\begin{array}{l}\text { 세부사업으로 } \\
\text { 정보화 포함 }\end{array}$ \\
\hline & (4) 문화시설 확충(지역자율) & I-2-재정(4) & 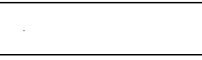 \\
\hline & (5) 문화시설 확충(제주) & ।-2-재정(5) & 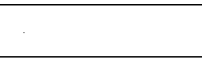 \\
\hline & (6) 문화시설 확충(세종) & ।-2-재정(6) & 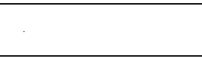 \\
\hline & (7) 문화도시 조성(지역지원) & ।-2-재정(7) & \\
\hline & (8) 시각예술 진흥기반 구축(지역자율) & ।-2-재정(8) & \\
\hline \multicolumn{4}{|c|}{ 프로그램목표 |-3. 종교문화 지원으로 종교문화자원 보존 및 이용 활성화 } \\
\hline \multicolumn{4}{|c|}{ 프로그램목표 1-4. 아시아문화중심도시 조성을 통해 광주를 아시아 동시대 문화예술의 창조 플랫폼으로 육성 } \\
\hline \multicolumn{4}{|c|}{ 프로그램목표 | -5. 국립박물관 운영으로 국민의 역사문화 향유권 증진 및 만족도 제고 } \\
\hline \multicolumn{4}{|c|}{ 프로그램목표 | -6. 국어사용 환경 개선을 통한 국민의 언어생활 만족도 제고 } \\
\hline \multicolumn{4}{|c|}{ 프로그램목표 1-7. 국립중앙도서관 운영을 통한 국가지식 문화환경 조성 } \\
\hline \multicolumn{4}{|c|}{ 프로그램목표 | -8. 국립장애인도서관 운영을 통한 장애인 지식정보평등 환경 구현 } \\
\hline \multicolumn{4}{|c|}{ 프로그램목표 |-9. 한국문화의 해외홍보 활성화를 통한 국가이미지 제고 } \\
\hline \multicolumn{4}{|c|}{ 프로그램목표 |-10. 국립민속박물관 운영으로 민속문화의 진흥, 보급 및 선양 } \\
\hline \multicolumn{4}{|c|}{ 프로그램목표 |-11. 대한민국역사박물관 운영으로 근현대사 이해 제고, 국민의 자긍심 고양 } \\
\hline
\end{tabular}

자료: 문화체육관광부(2021), 2021년도 성과계획서 
‘1-2 지역문화 균형발전 및 생활 속 문화향유 기회 확대’를 실천하기 위한 주요 정책 과제는 세 가지이다. 첫째, 지역문화 균형발전 및 일상에서 누리는 생활문화 환경 조성, 둘째, 박물관도서관의 대중친화형 복합문화공간화 및 국민 삶의 질 향상, 셋째, 문화를 통한 지역재생 확산 및 지역문화기반 강화이다. 지역문화 전체를 총괄하는 대표성과지표 는 생활문화동호회 참여 동호회 수와 지역문화전문인력 양성사업 참여자 만족도로 설정 됐다. 프로그램의 전체 목표 수준과 내용을 고려할 때, 총괄적인 성과지표와 목표의 연 계에 명확하지 않은 상태이다. 프로그램 목표의 주제어인 “균형”, “문화향유”, "기회확 대”의 상위 가치와 직접적인 연계성이 명확하지 않다. 이러한 특성은 개별 단위사업에서 도 비슷하게 확인할 수 있다. 예산단위별 성과지표들이 설정돼 있으며 해당 재정사업이 완료된 이후 혹은 추진하는 과정에서 주목해야할 문화 예술의 실질적 혹은 결과지향적 성과에 대한 지표와 목표는 설정되지 않았다. 개별 재정사업에서 성과지표와 성과목표는 단순산출 성격이며 상위 수준의 성과목표에서 일관성을 유지하기 힘들다.

〈표 4-3〉 문체부 지역문화진흥 관련 성과계획서의 성과지표와 성과목표

\begin{tabular}{|c|c|c|c|}
\hline 구분 & 단위사업 & 성과지표 & 관련 예산사업(예산코드) \\
\hline \multirow{8}{*}{$\begin{array}{l}\text { 일 } \\
\text { 반 } \\
\text { 회 } \\
\text { 계 }\end{array}$} & \multirow{3}{*}{$\begin{array}{l}\text { 도서관 정보. } \\
\text { 정책체계 활성화 }\end{array}$} & (1) 공공도서관 등록 회원수(천명) & \multirow{3}{*}{\begin{tabular}{|l}
- 도서관정책개발 및 \\
서비스환경개선(301) \\
- 해외공공도서관조성(ODA) \\
(303)
\end{tabular}} \\
\hline & & (2) U-도서관 구축 운영 수(개) & \\
\hline & & (3) 해외공공(작은) 도서관 조성 수(개) & \\
\hline & \multirow{2}{*}{ 박물관 정책활성화 } & $\begin{array}{l}\text { (1) 국립 문화시설(박물관, 미술관, 도서관) } \\
\text { 야간 이용자 수(천명) }\end{array}$ & - 박물관·미술관 진흥지원(300) \\
\hline & & $\begin{array}{l}\text { (2) 지원 사립박물관 체험교육프로그램 참여자 } \\
\text { 수(천명) }\end{array}$ & - 국민문화향유권 확대(301) \\
\hline & \multirow{3}{*}{ 지역문화진흥 } & (1) 문화체육자원봉사 매칭 수(건) & \multirow{3}{*}{$\begin{array}{l}\text { - 지역문화 진흥(300) } \\
\text { - 어르신문화프로그램운영(306) } \\
\text { - 국민문화활동지원(307) } \\
\text { - 지역문화기반시설구축(310) } \\
\text { - 지역문화통합정보시스템구축 } \\
\text { (정보화)(500) }\end{array}$} \\
\hline & & (2) 어르신 문화프로그램 참여자 만족도(점) & \\
\hline & & $\begin{array}{l}\text { (3) 문화가 있는 날 전체 참여프로그램 수 } \\
\text { 집계(개) }\end{array}$ & \\
\hline \multirow{6}{*}{$\begin{array}{l}\text { 균 } \\
\text { 특 } \\
\text { 회 } \\
\text { 계 }\end{array}$} & $\begin{array}{l}\text { 문화시설확충 } \\
\text { (지역자율) }\end{array}$ & (1) 문화시설 확충 및 조성 지원 수(개) & - 문화시설 확충(지역자율)(300) \\
\hline & 문화시설 확충(제주) & (1) 제주 문화시설 확충 및 조성 지원 수(개) & - 문화시설 확충(제주)(300) \\
\hline & 문화시설 확충(세종) & (1) 세종 문화시설 확충 및 조성 지원 수(개) & - 문화시설 확충(세종)(300) \\
\hline & \multirow{2}{*}{$\begin{array}{l}\text { 문화도시조성 } \\
\text { (지역지원) }\end{array}$} & $\begin{array}{l}\text { (1) 문화도시 지역특화프로그램 참여자 } \\
\text { 만족도(점) }\end{array}$ & \multirow{2}{*}{ - 문화도시 조성(지역지원)(300) } \\
\hline & & (2) 문화도시 지역특화프로그램 수(개) & \\
\hline & $\begin{array}{c}\text { 시각예술진흥기반 구축 } \\
\text { (지역자율) }\end{array}$ & $\begin{array}{l}\text { (1) 산업단지, 폐산업시설 문화재생사업 지원 } \\
\text { 개소 수(개수) }\end{array}$ & $\begin{array}{l}\text { - 폐산업시설 등 유휴공간 } \\
\text { 문화재생사업(지역자율)(302) }\end{array}$ \\
\hline
\end{tabular}

자료: 문화체육관광부(2021), 2021년도 성과계획서 
예산재원의 상황에 따라 임의적으로 설정된 경향이 있다 이는 전략목표와 프로그램의 목적지향성이 명확히 확보되지 않았기 때문이다. 일반회계와 균특회계로 구분하여 회계 별로 재정사업의 운영이 분리되면 통합적인 성과관리체계를 구축하기 힘든 특성이 있다. 균특회계 사업의 재정규모가 절대적으로 크며, 균특회계는 부처의 자체적인 계획과 함께 기획재정부의 세입관리와 국가균형발전위원회의 정책개입이 추가되는 복잡한 재정운영 체계를 가지고 있다.

2021년도 문화체육관광부 성과관리 시행계획에서 성과지표는 전략목표 6개, 성과목 표 22개, 관리과제 67개를 설정하고 있는데, 지역문화 관련한 성과지표는 67개 관리과 제 중 하나로 설정되어 있다. 성과목표 ' I-2. 생활 속 문화기반을 조성한다' 하부 '(1)지 역문화 활성화가 해당되는 관리과제이며, 성과지표는 지역문화전문인력 양성사업 참여 자 만족도, 생활문화동호회 지원사업 참여 동호회 수이다.

〈표 4-4〉문체부 지역문화정책 성과지표(성과관리 시행계획)

\begin{tabular}{|c|c|c|}
\hline \multicolumn{2}{|r|}{ 구분 } & 성과지표 \\
\hline 성과목표 & | -2. 생활 속 문화기반을 조성한다 & 지역 문화기반시설 수(개) \\
\hline \multirow[t]{4}{*}{ 관리과제 } & (1) 지역문화 활성화 & $\begin{array}{l}\text { · 지역문화전문인력 양성사업 참여자 만족도(점) } \\
\text { · 생활문화동호회 지원사업 참여 동호회수(개) }\end{array}$ \\
\hline & (2) 전통문화 진흥 & $\begin{array}{l}\text { 전통문화 대표분야(한복) 활성화 프로그램 참가자 수(명) } \\
\text {. 전통문화 대표분야(한복, 한지) 육성사업 만족도(점) }\end{array}$ \\
\hline & (3) 국어 발전 기반 조성 및 진흥 & $\begin{array}{l}\cdot \text { 국어생활종합상담실 이용자 만족도(점) } \\
\text {. 한국어교수학습샘터 이용자 수(명) }\end{array}$ \\
\hline & (4) 종교문화활동 및 보존지원 & $\begin{array}{l}\text {. 종교문화행사 참여자 만족도(점) } \\
\text { · 종교문화행사 참여자 수(명) }\end{array}$ \\
\hline
\end{tabular}

자료: 문화체육관광부(2021), 2021년 성과관리 시행계획

관리과제 '지역문화 활성화’의 성과관리 체계에서 중앙정부의 지역문화정책 목표를 정리할 수 있는데 이는 지역 간 격차해소, 지역별 특색있는 고유문화의 발전, 지역 주민 삶의 질 향상을 위한 지역문화정책 추진 등 크게 3가지이다.

재정사업들은 문화기반 확충, 문화서비스 확대, 문화역량 강화에 기본 방향을 두고 있 다. 구체적으로 지역밀착형 시설 확충, 문화도시 조성, 문화혁신브랜드 육성, 지역원천콘 텐츠 발굴, 일상 속 생활문화 지원(동호회, 어르신 등), 지역문화전문인력양성, 지역문화 협치기반 구축 등을 추진한다. 


\section{다. 문화체육관광부의 지역문화예산 특징}

\section{1) 문화체육관광부 국고보조사업 현황}

2021년 문화체육관광부 총 지출 6조 8,637억원 중 국고보조사업은 63.3\% 수준인 4조 3,467억이며, 이 중 36.8\%(1조 5,976억원)가 지방자치단체 보조사업이고 나머지 63.2\%(2조 7,491억원)가 민간보조사업이다.

〈표 4-5〉문화체육관광부 부문별 국고보조금 현황(2021년)

(단위: 억 원, 개)

\begin{tabular}{c|c|c|c}
\hline 부문 & 계 & 지자체 보조 & 민간보조 \\
\hline 계 & 43,467 & 15,976 & 27,491 \\
\hline 문화예술 & 19,574 & 6,241 & 13,333 \\
\hline 체육 & 15,803 & 7,043 & 8,761 \\
\hline 관광 & 7,942 & 2,692 & 5,250 \\
\hline 문화및관광일반 & 147 & - & 147 \\
\hline
\end{tabular}

자료: 이나라도움(https://www.gosims.go.kr)

문화체육관광부 지방자치단체 국고보조금 1 조 5,976억원의 사업분류17)는 프로그램 18 개, 단위사업 14 개, 세부사업 77 개, 내역사업 276개로 국고보조가 많음 타부처와 비 교할 때 사업 수가 과다하게 분류되는 경향이 있다. 같은 기간 타 부처의 내역사업 수는 해양수산부 168 개(1조 3,175 억원), 환경부 198 개(6조 4,873억원), 농림축산식품부 206개(5조 358억원) 등이다.

〈표 4-6〉 문화체육관광부 소관 사업 수(2021년)

(단위: 억 원, 개)

\begin{tabular}{|c|c|c|c|c|c|}
\hline \multirow{2}{*}{ 구 분 } & \multirow{2}{*}{$\begin{array}{c}\text { 지자체 } \\
\text { 국고보조금 }\end{array}$} & \multicolumn{4}{|c|}{ 지자체 국고보조사업 수 } \\
\hline & & 프로그램 & 단위사업 & 세부사업 & 내역사업 \\
\hline 계 & 15,976 & 18 & 42 & 77 & 276 \\
\hline 문화예술 & 6,241 & 9 & 23 & 38 & 114 \\
\hline 체육 & 7,043 & 5 & 10 & 18 & 39 \\
\hline 관광 & 2,692 & 4 & 9 & 21 & 123 \\
\hline
\end{tabular}

자료: 이나라도움(https://wnw.gosims.go.kr)

17) 세출예산은 정책적 일관성을 고려하여 분야(부문), 프로그램, 단위사업, 세부사업 등 기능별로 구분되며 세부사업은 다시 지출용도에 따라 내역사업으로 분류되어 관리하고 있음 


\section{2) 문화예술정책실 소관 국고보조사업}

지역문화 관련 국고보조사업을 이해하기 위해 문화체육관광부 문화예술정책실18)의 지방자치단체 보조사업을 살펴보면 다음과 같다. 전체적으로 사업 간 재정규모에서 차이 가 상당하며 특정 대규모 사업을 제외하면 소규모 예산사업으로 구성되어 있다. 포괄보 조를 통한 문화분권 활성화를 위해서는 문화예술의 특정 영역에 대해 서비스, 시설, 인 력에 대한 통합적 지원체계 형성이 필요하다.

그런데 현재 문화예술정책실 하부 부서별 재정기능분담은 조직 차원에서 분리된 상태 이다. 문화시설 건립 재정사업은 지역문화정책관 소관이 많고, 문화서비스에 대한 이용 과 전문인력 관련 재정사업은 예술정책관 소관이 많다. 통합문화이용권, 교육 및 강사지 원 사업 등이 대표적인 사례이다.

〈표 4-7〉 문체부 문화예술정책실 소관 지자체 국고보조사업(2021)

(단위: 백만원, \%)

\begin{tabular}{|c|c|c|c|c|c|c|}
\hline 부세 & 유형 & 세부사업 & 내역사업 & 국비 & $\begin{array}{l}\text { 국고 } \\
\text { 보조율 } \\
\end{array}$ & 비고 \\
\hline \multirow{11}{*}{$\begin{array}{l}\text { 문 } \\
\text { 화 } \\
\text { 정 } \\
\text { 책 } \\
\text { 관 }\end{array}$} & \multirow{11}{*}{$\begin{array}{l}\text { 지정 } \\
\text { 사업 }\end{array}$} & 소계 & & 14,076 & . & \\
\hline & & \multirow{2}{*}{ 문화정책개발및진흥 } & 문화다양성연구학교 & 40 & 정액 & $\begin{array}{l}\text { 지자처 } \\
\text { 학교 }\end{array}$ \\
\hline & & & 문화다양성축제맘프지원 & 500 & 정액 & 창원 \\
\hline & & 인문정신문화사회|적확산지원 & 21세기인문가치포럼 & 300 & 정액 & 안동 \\
\hline & & 국학진흥정책기반조성 & 전라유학진흥원건립계획수립 & 200 & 정액 & 전북 \\
\hline & & \multirow{2}{*}{ 동학농민혁명정신선양 } & 고창동학농민혁명성지화사업 & 500 & 50 & 고창 \\
\hline & & & 부안백산성지조성및세계시민혁명의전당건립 & 700 & 정액 & 부안 \\
\hline & & \multirow{2}{*}{ 전통생활문화진흥 } & 전국웇놀이대회개최지원 & 300 & 50 & 충남 \\
\hline & & & 한국문화원형콘텐츠체험및전시장건립 & 700 & 정률 & 전주 \\
\hline & & 전통스토리계승및활동 & 아름다운이야기할머니 & 10,236 & 70 & 전국 \\
\hline & & 국제문화정책지원 & 동아시아문화도시선정지원 & 600 & 정액 & 순천 \\
\hline \multirow{7}{*}{$\begin{array}{l}\text { 예 } \\
\text { 술 } \\
\text { 정 } \\
\text { 책 } \\
\text { 관 }\end{array}$} & \multirow{7}{*}{\begin{tabular}{|c|} 
지정 \\
사업
\end{tabular}} & 소계 & 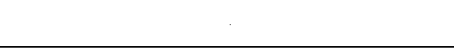 & 167,344 & 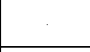 & 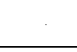 \\
\hline & & \multirow{3}{*}{ 문화예술인프라구축 } & 평택평화예술의전당건립 & 3,000 & 정액 & 평택 \\
\hline & & & 부산국제아트센터건립 & 2,450 & 50 & 부산 \\
\hline & & & 양주아트센터건립 & 1,636 & 정액 & 양주 \\
\hline & & 미술진흥기반구축 & 서예진흥 & 500 & 정액 & 전북 \\
\hline & & \multirow{2}{*}{ 문화예술교육활성화 } & 학교예술강사지원 & 5,813 & 50 & 전국 \\
\hline & & & 유아문화예술교육지원 & 1,700 & 50 & 전국 \\
\hline
\end{tabular}

18) 문화체육관광부 조직구성은 2차관 1차관보 1단 4실 5국 12관 58과 3팀으로 구성(2020.12월 기준)되어 있으며 이 중 지자체를 대상으로 문화사업을 추진하는 부서는 문화예술정책실로 볼 수 있음 


\begin{tabular}{|c|c|c|c|c|c|c|}
\hline 부서 & 유형 & 세부사업 & 내역사업 & 국비 & $\begin{array}{l}\text { 국고 } \\
\text { 보조율 }\end{array}$ & 비고 \\
\hline & & & 문화예술교육사인턴십지원 & 1,630 & 50 & 전국 \\
\hline & & & 지역문화예술교육기반구축 & 13,045 & 50 & 전국 \\
\hline & & 지역문화예술지원 & 공연장상주단체육성지원 & 6,127 & 정률 & 전국 \\
\hline & & \multirow{2}{*}{ 예술의관광자원화 } & 한옥자원활용야간상설공연 & 471 & 정액 & 전북 \\
\hline & & & 전통공연예술활동지원 & 172 & 정액 & 전국 \\
\hline & & 문화예술향유지원 & 통합문화이용권 & 123,900 & 정률 & 전국 \\
\hline & \multirow{3}{*}{$\begin{array}{l}\text { 공모 } \\
\text { 사업 }\end{array}$} & 공공디자인및공예문화진흥 & 국제문화예술행사개최도시지원 & 1,000 & \multicolumn{2}{|r|}{$\begin{array}{l}\text { 개최 } \\
\text { 도시 }\end{array}$} \\
\hline & & \multirow{2}{*}{ 문화예술교육활성화 } & 창의예술교육랩지원 & 900 & 50 & 전국 \\
\hline & & & 문화예술교육전용시설지원 & 5,000 & 50 & 전국 \\
\hline \multirow{24}{*}{$\begin{array}{l}\text { 지 } \\
\text { 역 } \\
\text { 문 } \\
\text { 화 } \\
\text { 정 } \\
\text { 책 } \\
\text { 관 }\end{array}$} & \multirow{12}{*}{$\begin{array}{l}\text { 지정 } \\
\text { 사업 }\end{array}$} & 소계 & & 335,486 & & \\
\hline & & \multirow{4}{*}{ 문화시설확충(지역자율) } & 공공도서관건립 & 175,923 & 40 & 전국 \\
\hline & & & 생활문화센터조성 & 60,987 & 40 & 전국 \\
\hline & & & 공공박물관건립지원 & 14,637 & 40 & 전국 \\
\hline & & & 작은도서관조성 & 6,527 & 40 & 전국 \\
\hline & & 므하시서홯츠(제즈) & 공공도서관건립지원 & 1,300 & 40 & 제주 \\
\hline & & ㅜㅜㄴ와시실돡웅(세주) & 생활문화센터조성 & 1,350 & 40 & 제주 \\
\hline & & 므내서하핯(세조) & 생활문화센터조성 & 600 & 40 & 세종 \\
\hline & & 눈와시리ㄹㅗㅚㄱ궁(세홍) & 작은도서관조성 & 98 & 70 & 세종 \\
\hline & & 지역문화기반시설구축 & 지역특화형문화시설건립방안연구 & 400 & 정책 & $\begin{array}{l}\text { 광주, } \\
\text { 진도 }\end{array}$ \\
\hline & & $\begin{array}{c}\text { 폐산업시설등유휴공간문화 } \\
\text { 재생사업(지역자율) }\end{array}$ & & 10,690 & 50 & $\begin{array}{l}\text { 인천 등 } \\
\text { 10개지 } \\
\text { 자체 }\end{array}$ \\
\hline & & $\begin{array}{c}\text { 폐산업시설등유휴공간문화 } \\
\text { 재생사업(세종) }\end{array}$ & & 150 & 50 & 세종 \\
\hline & & & U-도서관서비스지원사업 & 2,000 & 50 & 전국 \\
\hline & & \begin{tabular}{|l} 
도서관정책개발ㅁㅣㅣ서비스환 \\
겨ㄱㅐㅐㅅㅓ
\end{tabular} & 작은도서관육성시범지구지원 & 640 & 50 & 전국 \\
\hline & & $\begin{array}{c}\text { 상개닌ㄴ도서난시미스시눤 } \\
\text { 사업 }\end{array}$ & 도서관창작공간조성지원 & 2,250 & 50 & 전국 \\
\hline & & & 도서관다문화서비스운영지원 & 420 & 70 & 전국 \\
\hline & & 밤ㅁㄱㄱㅘ.미스과지흐지의 & 실감콘텐츠제작및체험존조성지원) & 10,000 & 50 & 전국 \\
\hline & 공모 & 닉룰놘·니룰난닌응시권 & 스마트박물관·미술관구축지원 & 6,700 & 50 & 전국 \\
\hline & 사업 & 국민문화향유권확대 & 공공도서관개관시간연장 & 18,844 & 50 & 전국 \\
\hline & & 지여무하지흐 & 지역문화혁신브랜드육성 & 100 & - & 전국 \\
\hline & & & 문화의달행사지원 & 270 & 50 & 전국 \\
\hline & & 구미무하화도지워 & 지역특화프로그램 & 1,800 & 50 & 전국 \\
\hline & & 둑닌분와왈동시권 & 예술동호회활동지원 & 1,800 & 50 & 전국 \\
\hline & & 문화도시조성 & 문화도시조성지원 & 18,000 & 50 & 전국 \\
\hline & & & & 516,906 & . & 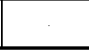 \\
\hline
\end{tabular}




\section{2) 지역문화정책관관 재정사업 분석}

2021년 본예산 기준 지역문화정책관 소관 재정사업 규모는 4,447 억원이고 모든 사 업이 [지역문화 진흥 및 문화기반 조성] 프로그램에 속해 있다. 재원의 구성은 일반회계 와 균특회계로 구분되어 있고 사업별 예산규모는 대체적으로 적은 편인 가운데 편차가 상당하다. 일반회계는 9개의 세부사업 1,540 억원이고(34.6\%), 균특회계는 6 개 세부사 업 2,907억원(65.4\%)으로 주로 도서관, 박물관, 생활문화센터 관련 예산이다.

〈표 4-8〉 문체부 지역문화정책관 소관 예산사업

(단위: 백만원, \%)

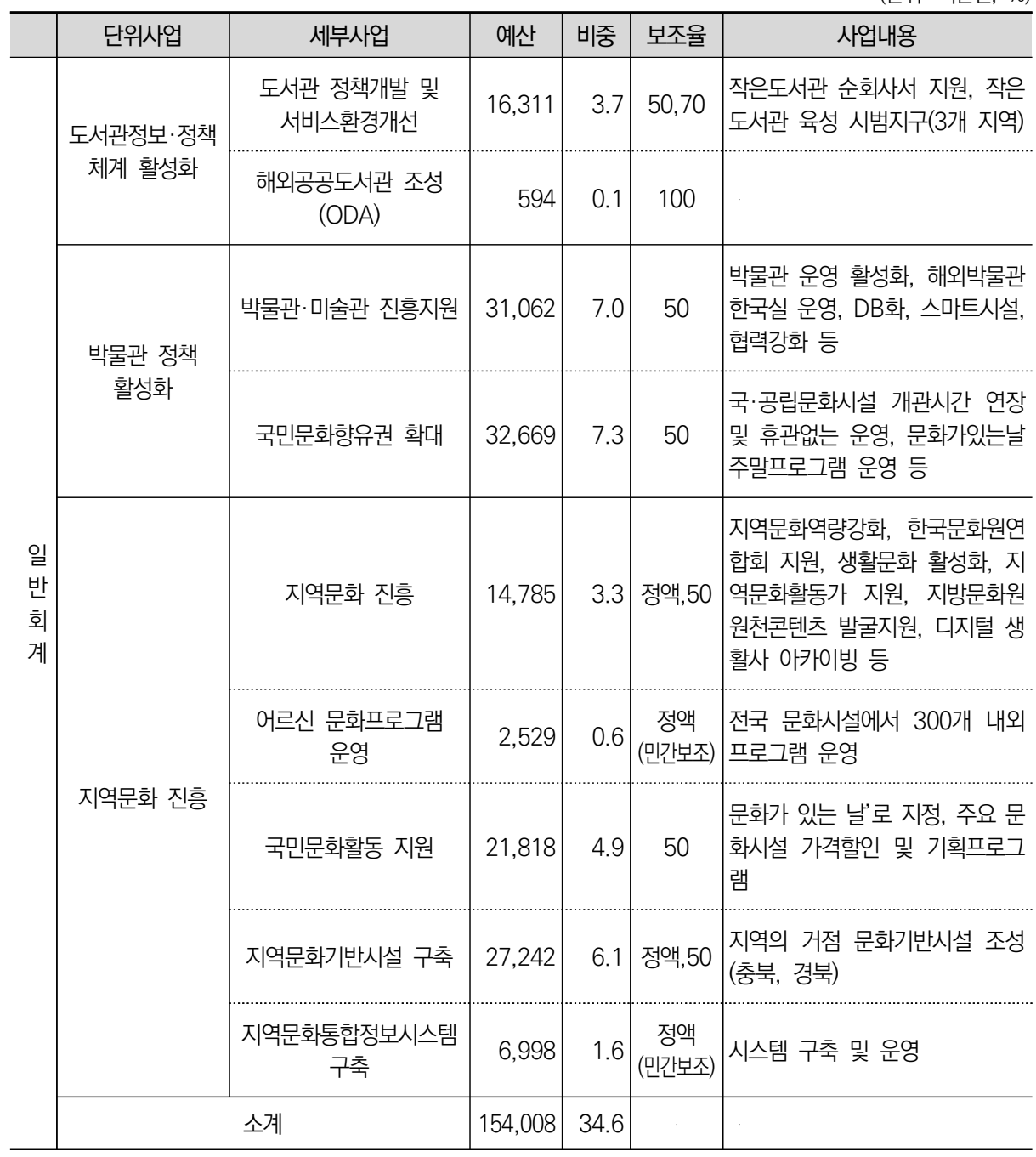




\begin{tabular}{|c|c|c|c|c|c|c|}
\hline & 단위사업 & 세부사업 & 예산 & 비중 & 보조율 & 사업내용 \\
\hline \multirow{7}{*}{$\begin{array}{l}\text { 균 } \\
\text { 특 } \\
\text { 회 } \\
\text { 계 }\end{array}$} & 문화시설 확충 & 문화시설 확충(지역자율) & 258,074 & 58.0 & 40 & \multirow{3}{*}{$\begin{array}{l}\text { 지역문화거점으로 활용하기 위한 } \\
\text { 문화시설 확충 }\end{array}$} \\
\hline & 문화시설 확충 & 문화시설 확충(제주) & 2,650 & 0.6 & 40 & \\
\hline & 문화시설 확충 & 문화시설 확충(세종) & 698 & 0.2 & 40 & \\
\hline & 문화도시 조성 & 문화도시 조성(지역지원) & 18,400 & 4.1 & 50 & $\begin{array}{l}\text { 문화도시 지자체당 최대 5년간 } \\
200 \text { 억원 지원(국비 } 100 \text { 억원) }\end{array}$ \\
\hline & $\begin{array}{c}\text { 시각예술 } \\
\text { 진흥기반 구축 }\end{array}$ & \begin{tabular}{|c|} 
폐산업시설 등 유휴공간 \\
문화재생사업(지역자율)
\end{tabular} & 10,690 & 2.4 & 50 & \multirow{2}{*}{$\begin{array}{l}\text { 제 기능을 잃은 유휴공간을 문화 } \\
\text { 예술로 재창조 }\end{array}$} \\
\hline & $\begin{array}{c}\text { 시각예술 } \\
\text { 진흥기반 구축 }\end{array}$ & $\begin{array}{c}\text { 폐산업시설 등 유휴공간 } \\
\text { 문화새생사업(세종) }\end{array}$ & 150 & 0.0 & 50 & \\
\hline & \multicolumn{2}{|r|}{ 소계 } & 290,662 & 65.4 & & \\
\hline \multicolumn{3}{|c|}{ 합계 } & 444,670 & 100.0 & & \\
\hline
\end{tabular}

국고보조율은 $50 \%$ 인 경우가 대부분이고 민간보조에서는 정액보조사업도 있다. 국고 보조금은 사업 수와 규모는 연도별로 불규칙적이지만 계속 증가하는 추세이고, 국비 보 다 지방비의 규모와 비중이 높은 특성이 있다. 총사업비 기준으로 2018년도는 4,814억 원에서 2020년도는 8,173억원으로 국고보조사업 규모가 증가하였는데, 균특회계에서 운영하는 문화시설확충사업비의 규모가 크고 나머지 사업은 소규모 예산이다. 일반회계 사업의 실효보조율은 2020 년 기준으로 $48.6 \%$ 이며 균특회계 사업의 보조율은 상대적으 로 낮은 $40.9 \%$ 수준이다. 문화시설확충 및 운영사업(자본)의 예산규모가 절대적으로 높 이기 때문에 이 사업의 보조율이 전체 보조율 수준을 결정한다. 일반회계와 균특회계를 합한 전체 사업에서 실효보조율은 $41.6 \%$ 이다.

〈표 4-9〉지역문화 진흥 관련 국고보조사업의 규모 추이

(단위: 억 원, \%)

\begin{tabular}{|c|c|c|c|c|c|c|c|c|}
\hline & \multirow{2}{*}{ 세부사업 (문화예술) } & \multirow{2}{*}{ 경비 } & \multicolumn{3}{|c|}{ 총사업비 } & \multicolumn{3}{|c|}{ 국고보조율 } \\
\hline & & & 2018 & 2019 & 2020 & 2018 & 2019 & 2020 \\
\hline \multirow{9}{*}{$\begin{array}{l}\text { 일 } \\
\text { 반 } \\
\text { 회 } \\
\text { 계 }\end{array}$} & 도서관정책개발및서비스환경개선 & 경상 & 7 & - & 6 & 70.0 & & 70.0 \\
\hline & 도서관정책개발및서비스환경개선 & 자본 & 40 & - & 33 & 49.1 & & 50.0 \\
\hline & 박물관·미술관진흥지원 & 자본 & 7 & - & 200 & 50.0 & & 50.0 \\
\hline & 국민문화향유권확대 & 경상 & 338 & 373 & 425 & 43.2 & 44.7 & 46.7 \\
\hline & 국민문화향유권확대 & 자본 & - & - & 16 & & & 62.5 \\
\hline & 지역문화진흥 & 경상 & 19 & 7 & 7 & 52.6 & 57.1 & 57.1 \\
\hline & 국민문화활동지원 & 경상 & 40 & 40 & 36 & 50.0 & 50.0 & 50.0 \\
\hline & 지역문화기반시설구축 & 자본 & - & 20 & - & & 50.0 & \\
\hline & 소계 & - & 451 & 440 & 723 & 45.3 & 45.7 & 48.6 \\
\hline
\end{tabular}




\begin{tabular}{|c|c|c|c|c|c|c|c|c|}
\hline & \multirow{2}{*}{ 세부사업 (문화예술) } & \multirow{2}{*}{ 경비 } & \multicolumn{3}{|c|}{ 총사업비 } & \multicolumn{3}{|c|}{ 국고보조율 } \\
\hline & & & 2018 & 2019 & 2020 & 2018 & 2019 & 2020 \\
\hline \multirow{6}{*}{$\begin{array}{l}\text { 균 } \\
\text { 특 } \\
\text { 회 } \\
\text { 계 }\end{array}$} & 문화시설확충및운영(지역자율) & 경상 & 966 & 769 & - & 40.0 & 51.4 & \\
\hline & 문화시설확충및운영(지역자율) & 자본 & 3,319 & 4,582 & 6,954 & 39.3 & 43.0 & 40.3 \\
\hline & 문화도시조성(지역지원) & 경상 & - & - & 200 & & & 50.0 \\
\hline & 산업단지,폐산업시설문화재생사업 & 자본 & 74 & 148 & 276 & 50.0 & 50.0 & 50.0 \\
\hline & 산업단지,폐산업시설문화재생사업 & 경상 & 4 & 13 & 21 & 50.0 & 50.0 & 50.0 \\
\hline & 소계 & - & 4,363 & 5,512 & 7,451 & 39.7 & 44.4 & 40.9 \\
\hline & 합계 & - & 4,814 & 5,951 & 8,173 & 40.2 & 44.5 & 41.6 \\
\hline
\end{tabular}

자료: 박병희·이재원·이종하(2020), 국고보조사업 분류체계 개편에 관한 연구. 한국지방재정공제회.

재정적인 규모와 내역만을 고려하면 지역문화사업은 '지역문화시설 건립과 이용'에 대한 것으로 해석될 수 있다. 특히 지역문화정책관 균특회계 보조사업 규모는 2,907억 원으로 부서 소관 예산의 $65.4 \%$ 를 차지하고, 이 가운데 문화시설확충(지역자율) 사업의 규모가 절대적으로 많은 2,614억원이다. 문화시설확충 사업은 공공도서관, 공공박물관, 생활문화센터, 작은도서관 조성 지원에 대한 내용이고, 수용비, 행사성 비용, 기관·단체 운영비, 개인의 국외 연수비용 등에는 예산사용이 불가하다.

〈표 4-10〉문화시설확충 사업내용(균특회계 지역자율)

\begin{tabular}{c|l}
\hline \multicolumn{1}{c|}{ 사업명 } & \multicolumn{1}{c}{ 사 업 내 용 } \\
\hline 공립박물관 건립 지원 & 지역의 문화유산 보존·전시 등을 위한 박물관 건립(개보수 포함) 지원 \\
\hline 공공도서관 건립 지원 & $\begin{array}{l}\text { 종합정보센터로서의 국민의 정보 접근권 및 문화향수권 제고를 위한 공공도서관 건립 } \\
\text { 지원 }\end{array}$ \\
\hline 생활문화센터 조성 & $\begin{array}{l}\text { 유휴공간 리모델링 또는 복합시설 조성으로 지역주민의 일상 속 자발적·주체적 문화 } \\
\text { 예술 활동 공간인 생활문화공간 조성 }\end{array}$ \\
\hline 작은도서관 조성 & $\begin{array}{l}\text { 지역주민의 지식정보 접근성 보장을 위한 작은도서관 조성 지원 } \\
\text { (공공시설 유휴 공간을 리모델링하여 작은도서관으로 활용) }\end{array}$ \\
\hline
\end{tabular}

자료: 문화체육관광부(2020), 균특회계 포괄보조사업 가이드라인

2020년 기준 전국 문화기반시설은 총 3,017개이고 매년 꾸준하게 증가하고 있으며, 특히 공공도서관의 증가율이 높다. 2020년 기준 공공도서관(국립포함) 1,137 개, 박물관 897 개, 미술관 267개, 생활문화센터 129개, 문예회관 256개, 지방문화원 230개, 문화 의 집 101 개가 운영되고 있다. 
〈표 4-11〉 전국 문화기반시설 연도별 현황(개)

\begin{tabular}{c|c|c|c|c|c|c|c|c|c}
\hline 연도별 & 총 계 & $\begin{array}{c}\text { 국립 } \\
\text { 도서관 }\end{array}$ & $\begin{array}{c}\text { 공공 } \\
\text { 도서관 }\end{array}$ & 박물관 & 미술관 & $\begin{array}{c}\text { 생활문화 } \\
\text { 센터 }\end{array}$ & 문예회관 & $\begin{array}{c}\text { 지방 } \\
\text { 문화원 }\end{array}$ & 문화의 집 \\
\hline 2020 & 3,017 & 3 & 1,134 & 897 & 267 & 129 & 256 & 230 & 101 \\
\hline 2019 & 2,825 & 3 & 1,096 & 881 & 258 & - & 255 & 231 & 101 \\
\hline 2018 & 2,749 & 1 & 1,042 & 873 & 251 & - & 251 & 231 & 100 \\
\hline 2017 & 2,657 & 1 & 1,010 & 853 & 229 & - & 236 & 228 & 100 \\
\hline 2016 & 2,595 & 1 & 978 & 826 & 219 & - & 229 & 228 & 114 \\
\hline 2015 & 2,519 & 1 & 930 & 809 & 202 & - & 232 & 229 & 116 \\
\hline 2014 & 2,375 & 1 & 865 & 754 & 190 & - & 220 & 229 & 116 \\
\hline 2013 & 2,182 & - & 828 & 740 & 171 & - & 214 & 229 & - \\
\hline
\end{tabular}

주 1) 국립중앙도서관, 문화의 집('14 ), 생활문화센터('20 )를 통계에 포함

2) 2019년부터 국립도서관(국회도서관, 법원도서관) 2 개관을 통계에 포함

자료: 문화체육관광부(2021), 2020 전국문화기반시설총람

[그림 4-2] 전국 문화기반시설 연도별 현황(개)

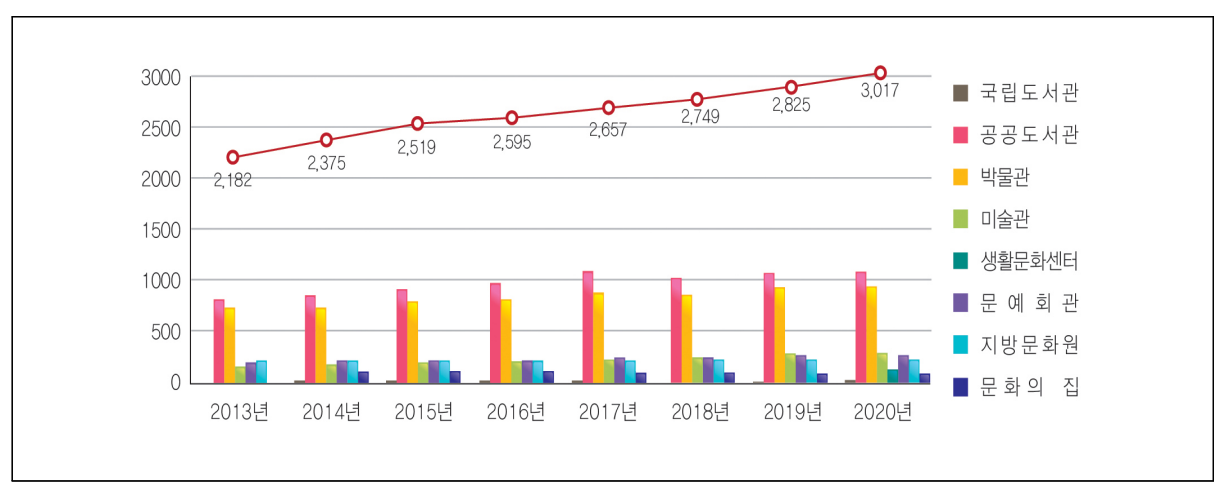

17 개 시·도별로 살펴보면 수도권 3 개 시·도(서울, 인천, 경기)에 문화시설의 $36.2 \%$ 가 분포되어 있지만, 인구 백만명 당 시설 수는 수도권 42개, 수도권 이외 74개로 지역별 인구대비 문화시설은 수도권 이외 지역이 더 많다. 주로 광역도의 관할구역에 해당되는 지역이자 재정자립도가 낮은 지역에 인구 백만명 당 문화시설이 많다. 지역문화를 활성 화하기 위해서는 시설 뿐 아니라 지역맞춤형 관점에서 이용자 중심의 프로그램 사업이 개발되어야 한다. 그러나 재정여건이 양호하지 않은 수도권 이외의 지역에 인구대비 문 화시설 개수가 많은 상황에서 문화시설 활성화에 대한 투자가 부족하여 지역격차가 악 화될 수 있다. 
〈표 4-12〉 전국 재정여력 및 문화기반시설 현황

(단위: 백만원, 개, \%)

\begin{tabular}{c|r|r|r|r|r|r}
\hline \multirow{2}{*}{ 지 역 } & \multirow{2}{*}{ 재정자립도 } & \multirow{2}{*}{$\begin{array}{c}\text { 지자체 문화예술 } \\
\text { 부문 예산(21년) }\end{array}$} & \multicolumn{2}{|c|}{ 문화시설 수 } & \multicolumn{2}{|c}{ 백만명당 문화시설 수 } \\
\cline { 5 - 7 } & & & \multicolumn{1}{c}{ 구성비 } & \multicolumn{1}{c}{ 개수 } & \multicolumn{1}{c}{ 순위 } \\
\hline 서울특별시 & 75.6 & 564,386 & 410 & 13.6 & 42.14 & 12 \\
\hline 부산광역시 & 46.1 & 279,278 & 124 & 4.1 & 36.32 & 17 \\
\hline 대구광역시 & 44.6 & 178,556 & 89 & 2.9 & 36.50 & 16 \\
\hline 인천광역시 & 50.3 & 191,114 & 115 & 3.8 & 38.89 & 15 \\
\hline 광주광역시 & 40.8 & 186,868 & 72 & 2.4 & 49.43 & 10 \\
\hline 대전광역시 & 39.9 & 112,102 & 62 & 2.1 & 42.04 & 13 \\
\hline 울산광역시 & 49.6 & 109,140 & 46 & 1.5 & 40.07 & 14 \\
\hline 세종특별자치시 & 58.8 & 36,248 & 22 & 0.7 & 64.60 & 9 \\
\hline 경기도 & 57.3 & 862,605 & 567 & 18.8 & 42.83 & 11 \\
\hline 강원도 & 24.5 & 223,118 & 232 & 7.7 & 150.50 & 2 \\
\hline 충청북도 & 28.3 & 133,073 & 136 & 4.5 & 85.00 & 5 \\
\hline 충청남도 & 32.3 & 185,444 & 176 & 5.8 & 82.87 & 6 \\
\hline 전라북도 & 23.1 & 252,399 & 174 & 5.8 & 95.66 & 4 \\
\hline 전라남도 & 22.2 & 191,573 & 222 & 7.4 & 118.80 & 3 \\
\hline 경상북도 & 24.9 & 271,026 & 211 & 7.0 & 79.15 & 7 \\
\hline 경상남도 & 33.5 & 216,341 & 221 & 7.3 & 65.72 & 8 \\
\hline 제주특별자치도 & 32.7 & 93,704 & 138 & 4.6 & 205.67 & 1 \\
\hline 총 계 & $263,091,736$ & 3,017 & 100.0 & 58.19 & - \\
\hline
\end{tabular}

주: 재정자립도, 지자체 문화예술부문 예산은 2021년, 시설 수는 2020년말 기준

자료: 문화체육관광부(2021), 2020 전국문화기반시설총람

\section{2. 지역문화진흥계획 제도와 현황}

\section{가. 도입배경 및 기본계획}

지역문화정책 추진체제가 견고해진 것은 2014년 「지역문화진흥법」 제정을 계기로 지 방자치단체 자체적으로 지역의 문화정책 계획을 수립하도록 명시되면서 부터이다.

2020년 2월「지역문화진흥법」 제6조에 근거한 법정계획인「제2차 지역문화진흥 기 본계획(2020 2024)」가 수립·발표되었다. 동 계획은 ‘포용과 혁신의 지역문화라는 비 전에 따라 시민의 참여로 문화자치 생태계 구축, 포용과 소통으로 생활기반 문화환경 
조성, 지역의 개성 있는 문화 발굴·활용, 문화적 가치로 지역의 혁신과 발전이라는 4 개 의 전략과 15 개의 핵심과제를 도출했다.

[그림 4-3] 제2차 지역문화진흥기본계획(2020 2024)

\begin{tabular}{|c|c|}
\hline 비전 & 포용과 혁신의 지역문화 \\
\hline \multirow{3}{*}{$\begin{array}{l}\text { 가치- } \\
\text { 목표 }\end{array}$} & 자 치 \\
\hline & \begin{tabular}{c|c} 
내가 만드는 & 모두가 누리는 \\
지이격문훈화
\end{tabular} \\
\hline & $\begin{array}{l}\text { 지자체 문화예술 재정 비율 증대 ('19년 } 1.6 \% \rightarrow \text { '24년 } 1.8 \%) \\
\text { 지역규모별 문화향유 격차감소 ('19년 } 12.7 \% p \rightarrow \text { '24년 } 10 \% \text { ) }\end{array}$ \\
\hline \multicolumn{2}{|r|}{-} \\
\hline \multirow{4}{*}{$\begin{array}{l}\text { 전략 } \\
\text { 및 } \\
\text { 핵심 } \\
\text { 과제 }\end{array}$} & 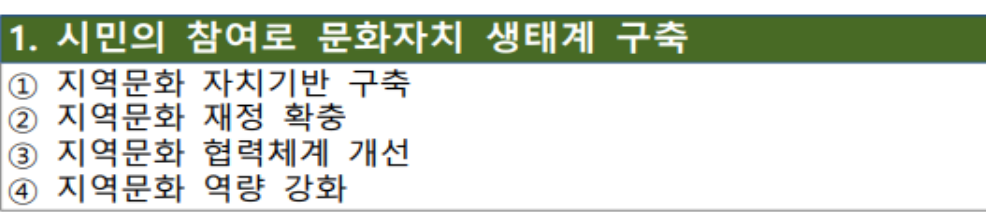 \\
\hline & 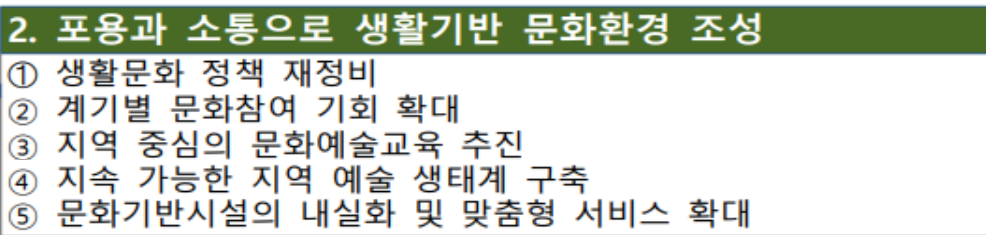 \\
\hline & 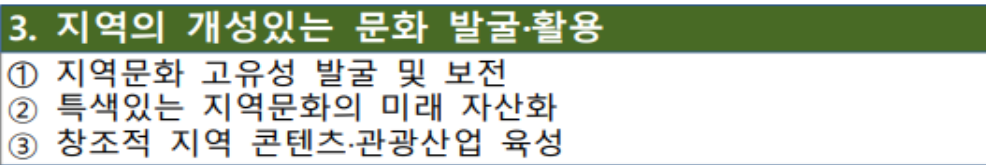 \\
\hline & 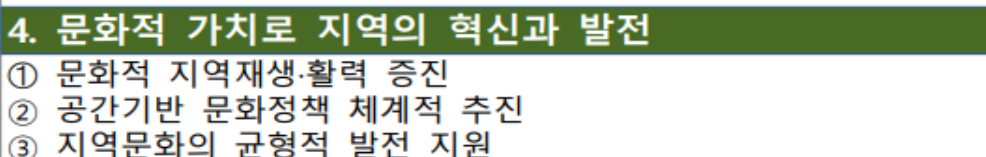 \\
\hline
\end{tabular}




\section{나. 시도 시행계획 분석}

국가 수준의 지역문화 정책인 '지역문화진흥기본계획'을 문화체육관광부 장관이 5년 마다 수립하고 각 지방자치단체장은 기본계획을 반영하여 지역 실정에 맞게 시행계획을 수립·시행·평가해야 한다.

시도별 지역문화진흥시행계획은 각 지방자치단체 마다 크고 작은 차이는 있으나 대체로 비전에는 “행복”, “문화”, “문화도시”를 목표에는 “지역문화”, “모두가” 등을 강조하고 있다. 시행계획의 전체적인 틀과 방향은 중앙정부가 세운 기본계획을 반영하고 있는데, 지방자치 단체 에서 새로운 표현으로 등장한 비전은 ‘행복'이다. 많은 지방자치단체 에서 “행복”을 문 화정책의 비전에 담아내고 있으며 이는 지역주민의 행복을 지역문화정책의 주요 가치이자 미래상으로 비라본다는 것을 의미한다. 지방자치단체 시행계획의 목표는 대체로 중앙정부의 기본계획을 반영하고 있는데, 주민참여를 근간으로 구성하고 있는 특징을 나타낸다.

[그림 4-4] 시도 지역문화진흥 시행계획 워드클라우드 분석(비전, 목표)

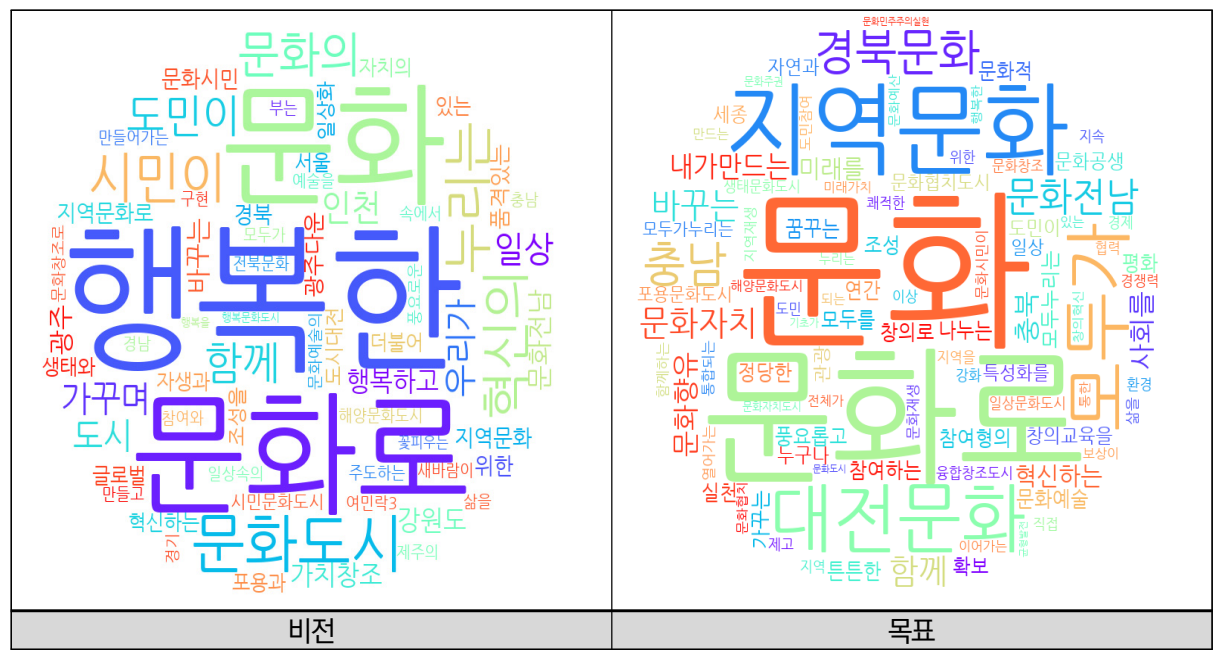

〈표 4-13〉시도 지역문화진흥 시행계획 구성

\begin{tabular}{c|c|c|c}
\hline 구분 & 비전 & 목표 & 전략체계 \\
\hline & & 문화주권 & \\
\multirow{3}{*}{ 서울 } & 문화시민 도시 서울-시민이 & 문화공생 & \\
& 만들어가는 행복한 문화도시 & 문화재생 & 5대목표 10대과제 \\
& & 문화창조 & \\
& & 문화협치 & \\
\hline
\end{tabular}




\begin{tabular}{|c|c|c|c|}
\hline 구분 & 비전 & 목표 & 전략체계 \\
\hline 부산 & $\begin{array}{l}\text { 시민이 주도하는 행복한 } \\
\text { 문화 글로벌 해양문화도시 }\end{array}$ & $\begin{array}{l}\text { 해양문화도시 } \\
\text { 포용문화도시 } \\
\text { 융합창조도시 } \\
\text { 문화협치도시 }\end{array}$ & 4대목표 10대전략 \\
\hline 대구 & 포용과 혁신의 지역문화 & $\begin{array}{c}\text { 내가만드는 지역문화 } \\
\text { 모두가누리는 지역문화 } \\
\text { 사회를 혁신하는 지역문화 }\end{array}$ & $\begin{array}{c}\text { 4대전략 } \\
\text { 15대 핵심과제 }\end{array}$ \\
\hline 인천 & $\begin{array}{c}\text { 함께 가꾸며 삶을 바꾸는 } \\
\text { 문화도시 인천 }\end{array}$ & $\begin{array}{l}\text { 직접 가꾸는 문화 } \\
\text { 함께 나누는 문화 } \\
\text { 삶을 바꾸는 문화 } \\
\end{array}$ & $\begin{array}{c}\text { 4대전략 } \\
\text { 16대 핵심과제 }\end{array}$ \\
\hline 광주 & $\begin{array}{l}\text { 문화의 일상화·광주다운 } \\
\text { 문화창조로 품격있는 } \\
\text { 문화도시 광주 }\end{array}$ & $\begin{array}{l}\text { 문화민주주의실현 } \\
\text { 문화적 지역재생 }\end{array}$ & $\begin{array}{c}\text { 4대전략 } \\
\text { 15대 추진과제 }\end{array}$ \\
\hline 대전 & $\begin{array}{c}\text { 문화로 행복을 누리는 } \\
\text { 도시대전 }\end{array}$ & $\begin{array}{c}\text { 내가만드는 대전문화 } \\
\text { 모두가 문화시민이 되는 대전문화 } \\
\text { 꿈꾸는 미래를 이어가는 대전문화 }\end{array}$ & $\begin{array}{c}\text { 4대전략 } \\
\text { 9대 핵심과제 }\end{array}$ \\
\hline 울산 & $\begin{array}{c}\text { 생태와 일상 속에서 예술을 } \\
\text { 꽃피우는 시민문화도시 }\end{array}$ & $\begin{array}{l}\text { 생태문화도시 } \\
\text { 일상문화도시 } \\
\text { 문화자치도시 }\end{array}$ & $\begin{array}{c}\text { 4대전략 } \\
\text { 12대 핵심과제 }\end{array}$ \\
\hline 세종 & $\begin{array}{l}\text { 여민락3.0 행복문화도시 } \\
\text { 조성을 위한 }\end{array}$ & $\begin{array}{c}\text { 문화향유 세종, 창의교육을 실천, 시 } \\
\text { 전체가 문화로 통합되는 문화도시 }\end{array}$ & $\begin{array}{c}\text { 5대전략 } \\
\text { 12대 핵심과제 }\end{array}$ \\
\hline 경기 & $\begin{array}{c}\text { 도민이 있는 문화, 모두가 } \\
\text { 행복한 경기 }\end{array}$ & $\begin{array}{l}\text { 도민이 참여하는 문화 } \\
\text { 정당한 보상이 있는 문화 } \\
\text { 누구나 누리는 문화 }\end{array}$ & $\begin{array}{c}\text { 4대전략 } \\
\text { 15대 핵심과제 }\end{array}$ \\
\hline 강원 & 문화로 행복한 강원도 & $\begin{array}{l}\text { 문화로 평화 } \\
\text { 문화로 관광 } \\
\text { 문화로 경제 }\end{array}$ & $\begin{array}{c}\text { 5대전략 } \\
\text { 14대 핵심과제 }\end{array}$ \\
\hline 충북 & $\begin{array}{l}\text { 도민이 함께 행복한 } \\
\text { 일상속의 문화 }\end{array}$ & $\begin{array}{c}\text { 도민 참여형의 일상 속 문화향유 환경 조성 } \\
\text { 충북 자연과 지역문화 특성화를 통한 지역 } \\
\text { 경쟁력 제고 } \\
\text { 충북 문화예술 협력 강화 및 연간 문화예산 } \\
2.0 \% \text { 이상 확보 지속 }\end{array}$ & $\begin{array}{c}\text { 4대전략 } \\
\text { 17대 핵심과제 }\end{array}$ \\
\hline 충남 & $\begin{array}{c}\text { 문화로 행복하고 풍요로운 } \\
\text { 충남 }\end{array}$ & $\begin{array}{c}\text { 모두가 행복한 충남 } \\
\text { 풍요롭고 쾌적한 충남 } \\
\text { 창의로 미래를 열어가는 충남 }\end{array}$ & $\begin{array}{c}\text { 4대전략 } \\
\text { 12대 핵심과제 }\end{array}$ \\
\hline 전북 & $\begin{array}{c}\text { 우리가 만들고 더불어 } \\
\text { 누리는 전북문화 }\end{array}$ & $\begin{array}{l}\text { 문화자치 } \\
\text { 균형발전 } \\
\text { 창의혁신 }\end{array}$ & $\begin{array}{c}\text { 3대전략 } \\
\text { 12대 핵심과제 }\end{array}$ \\
\hline 전남 & 자생과 혁신의 문화전남 & $\begin{array}{l}\text { 기초가 튼튼한 문화전남 } \\
\text { 모두가 함께하는 문화전남 } \\
\text { 지역을 바꾸는 문화전남 }\end{array}$ & $\begin{array}{c}\text { 4대전략 } \\
\text { 15대 핵심과제 }\end{array}$ \\
\hline 경북 & 문화의 새바람이 부는 경북 & $\begin{array}{c}\text { 함께 만드는 경북문화 } \\
\text { 모두를 위한 경북문화 } \\
\text { 사회를 혁신하는 경북문화 }\end{array}$ & $\begin{array}{c}\text { 4대전략 } \\
\text { 12대 핵심과제 }\end{array}$ \\
\hline
\end{tabular}




\begin{tabular}{c|c|c|c}
\hline 구분 & 비전 & 목표 & 전략체계 \\
\hline \multirow{4}{*}{ 경남 } & & 도민참여 & \\
& & 훈화아쳐와 & 자치의 지역문화로 \\
& 혁신하는 경남 & 모두누리는 & 4대전략 \\
& & 미래가치 \\
& & 지속가능 & 15대 핵심과제 \\
& & 제주의 가치창조, & \\
\hline \multirow{2}{*}{ 제주 } & 문화예술의 섬 구현 & 민이 행복한 문화예술의 섬 조성 추진 & 4대전략 \\
& 15대 핵심과제 \\
\hline
\end{tabular}

시도별 추진전략을 살펴보면 동사(조성, 활용, 구축)를 제외하고 “문화자치”, “생태 계", “문화환경”, “생활기반” 등의 내용이 주로 사용되는데, 전반적으로 정책대상이나 지 원분야에 대한 내용보다 추상적인 표현이 많다. 주요사업 내용을 살펴보면, 지역전통, 일상문화활동(생활문화, 동호회), 인력양성, 예술인 창작지원 및 복지, 예술교육, 문화시 설 개보수, 창업연계, 콘텐츠 및 관광연계 지원 등 생활권 내 다양한 사업이 배열되어 있다. 각 지방자치단체 의 사업 우선순위가 잘 드러나지 않고 있다.

성과지표를 나타내는 정책목표는 많은 자치단체에서 설정하지 않고 있었으며, 부산, 인 천, 전북, 전남, 경남 5 개 지방자치단체 에서는 정책목표를 정량적으로 설정하고 있었다. 지 표는 문화재정(예산) 비율을 사용하는 경우가 가장 많고 문화지수, 문화향유 격차, 문화도시 조성, 주민참여예산 등을 설정하고 있었다. 지역별 성과목표가 제대로 설정되지 않거나 정성 적으로 설정되어 목표로서 구체성이 미흡하고, 일부 지방자치단체 에서 설정하고 있는 정량 목표 역시 문화재정 비율과 문화향유 격차는 중앙에서 제시한 성과지표로 한정된 것이라 지 역 내 차별화된 고유의 사업을 추진한다면 특성화된 성과지표도 발굴되어야 할 것이다.

[그림 4-5] 시도 지역문화진흥 시행계획 워드클라우드 분석(전략)

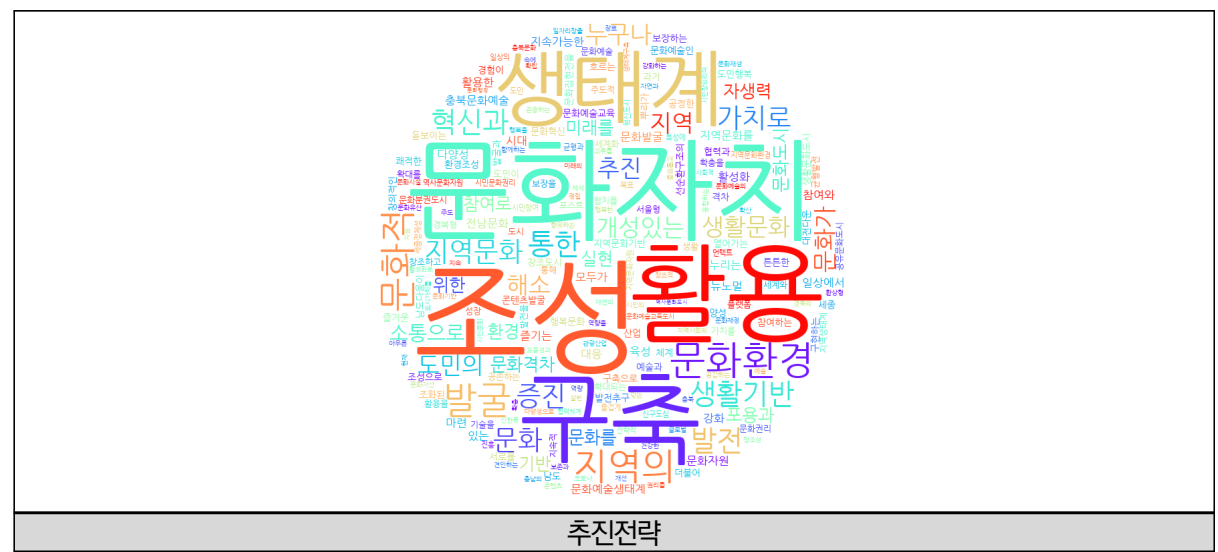


〈표 4-14〉시도 지역문화진흥 시행계획 전략과제 및 정량목표

\begin{tabular}{|c|c|c|}
\hline 구분 & 전략과제 & 정량목표 \\
\hline 서울 & $\begin{array}{l}\text { 서울형 생활문화 활성화 } \\
\text { 문화예술교육 체계 구축 } \\
\text { 예술 생태계 자생력 강화 및 장르 지원 } \\
\text { 문화시설 전략적 구축 } \\
\text { 역사문화자원 발굴 및 활용 }\end{array}$ & - \\
\hline 부산 & $\begin{array}{l}\text { 세계와 공존하는 글로벌 문화도시 } \\
\text { 과거·현재·미래를 아우른 '역사문화도시' } \\
\text { 서로를 존중하는 '다양성 문화도시' } \\
\text { 행복을 공감하는 '공유문화도시' } \\
\text { 일상에서 즐기는 '생활문화도시' } \\
\text { 예술과 기술을 융합하는 '플랫폼 도시' } \\
\text { 문화예술인 권리를 보장하는 '창조도시' } \\
\text { 시민문화 역량을 강화하는 '문화예술교육도시' } \\
\text { 문화권리 보장을 위한 '문화행정 혁신도시' } \\
\text { 참여와 협치를 구현하는 '문화분권도시' }\end{array}$ & $\begin{array}{c}\text { 박물관 수, 문화영향평가모델, } \\
\text { 문화예산비율 }\end{array}$ \\
\hline 대구 & $\begin{array}{l}\text { 문화자치 생태계 구축 } \\
\text { 포용과 소통으로 생활기반 문화환경 조성 } \\
\text { 지역의 개성있는 문화발굴·활용 } \\
\text { 문화적 가치로 지역의 혁신과 발전 }\end{array}$ & - \\
\hline 인천 & $\begin{array}{l}\text { 문화자치 기반 조성 } \\
\text { 문화적 포용성과 다양성 증진 } \\
\text { 지역문화자원 발굴·활용 진흥 } \\
\text { 문화격차 해소 및 문화재생 추진 }\end{array}$ & 주민참여예산 인천사회지표 \\
\hline 광주 & $\begin{array}{l}\text { 지역의 특성에 맞는 문화자치 생태계 구축 } \\
\text { 생활문화 활성화로 지역문화환경 조성 } \\
\text { 지역의 개성있는 문화 발굴·활용 } \\
\text { 지역문화를 활용한 지속가능한 발전추구 }\end{array}$ & - \\
\hline 대전 & $\begin{array}{l}\text { 모두가 즐거운 문화자치 생태계 정립 } \\
\text { 일상의 경험이 확대되는 생활기반 문화환경 조성 } \\
\text { 대전다운 문화자원 발굴 및 활용 } \\
\text { 문화적 가치로 대전의 지속적 혁신과 발전 주도 }\end{array}$ & - \\
\hline 울산 & $\begin{array}{l}\text { 일상에서 누리는 문화 } \\
\text { 건강한 문화예술 생태계 } \\
\text { 문화예술의 사회적 확산 } \\
\text { 참여와 교류를 통한 문화혁신 }\end{array}$ & - \\
\hline 세종 & $\begin{array}{l}\text { 문화가 흐르는 신구도심 균형발전 } \\
\text { 세종 문화집현전을 통한 시민창의리더 양성 } \\
\text { 시민참여 확대를 통한 시민문화권리 증진 } \\
\text { 뿌리가 튼튼한 행복문화 생태계구축 } \\
\text { 환상형 도시가치를 살린 세종정체성 확립 }\end{array}$ & - \\
\hline
\end{tabular}




\begin{tabular}{|c|c|c|}
\hline 구분 & 전략과제 & 정량목표 \\
\hline 경기 & $\begin{array}{l}\text { 누구나 문화를 창조하고 향유하는 환경 조성 } \\
\text { 공정한 문화예술생태계 조성으로 도민행복 증진 } \\
\text { 문화기반 확충을 통한 문화격차 해소 및 지역문화 활성화 } \\
\text { 문화유산 보존과 활용을 통해 더불어 즐겁게 } \\
\text { 창조적 지역 콘텐츠•관광산업 육성 } \\
\text { 포스트 코로나 시대 지역문화 뉴노멀 마련 }\end{array}$ & - \\
\hline 강원 & $\begin{array}{l}\text { 선순환구조의 문화예술생태계 구축 } \\
\text { 도민의 문화가 있는 삼 추진 } \\
\text { 신한류 문화자원 및 콘텐츠발굴 육성 } \\
\text { 문화적 일자리창출 } \\
\text { 언텍트 문화환경 조성 }\end{array}$ & - \\
\hline 충북 & $\begin{array}{l}\text { 도민의 생활 속에 함께하는 충북문화예술 환경조성 } \\
\text { 자연과 문화가 조화된 충북문화 세계화 추진 } \\
\text { 뉴노멀 시대 대응 충북문화예술(산업) 역량 강화 } \\
\text { 충북 문화자치 협력체계 개선/문화재정 확충 }\end{array}$ & - \\
\hline 충남 & $\begin{array}{l}\text { 도민 누구나 행복한 문화자치 실현 } \\
\text { 풍요롭고 쾌적한 생활기반 문화환경 조성 } \\
\text { 충남의 창의적인 문화자산 발굴과 활용 } \\
\text { 미래의 가치를 열어가는 지역문화 }\end{array}$ & - \\
\hline 전북 & $\begin{array}{l}\text { 지역생태계 구축으로 문화자치 기반 마련 } \\
\text { 균형과 다양성으로 지역문화기반 격차 해소 } \\
\text { 지역문화를 활용한 지역사회의 혁신과 발전 }\end{array}$ & $\begin{array}{c}\text { 문화재정 비율, 지역문화지수, } \\
\text { 문화도시 지정 }\end{array}$ \\
\hline 전남 & $\begin{array}{l}\text { 자생력 있는 전남문화 생태계 구축 } \\
\text { 누구나 즐기는 문화환경 조성 } \\
\text { 남도다움이 돋보이는 문화 발굴·활용 } \\
\text { 남도 발전을 견인하는 전남문화 }\end{array}$ & 문화재정 비율, 문화향유율 \\
\hline 경북 & $\begin{array}{l}\text { 도민의 주도적 참여로 문화자치 체제 대응 } \\
\text { 협력과 소통으로 생활기반 문화환경 조성 } \\
\text { 경북형 문화발굴 및 활용 } \\
\text { 문화적 가치로 경북의 혁신과 지속 성장 }\end{array}$ & - \\
\hline 경남 & $\begin{array}{l}\text { 도민이 참여하는 지역 문화자치 생태계 구축 } \\
\text { 모두가 누리는 생활문화 환경 조성 } \\
\text { 미래를 위한 지역문화 창조성 증진 } \\
\text { 문화를 통한 지속가능한 지역 발전 목표 실현 }\end{array}$ & $\begin{array}{c}\text { 문화예술재정비율, } \\
\text { 동부권서부권 지역문화지수 } \\
\text { 격차, 문화도시조성, } \\
\text { 문화공동체지원, 지역문화PD }\end{array}$ \\
\hline 제주 & $\begin{array}{l}\text { 시민의 참여로 문화자치 생태계 구축 } \\
\text { 포용과 소통으로 생활기반 문화환경 조성 } \\
\text { 지역의 개성있는 문화 발굴·활용 } \\
\text { 문화적 가치로 지역의 혁신과 발전 }\end{array}$ & - \\
\hline
\end{tabular}




\section{3. 지방자치단체의 문화예산 특징}

\section{가. 문화예산 규모}

문화예산은 정부총지출 대비 소규모 재정이고, 투자 비중은 중앙정부보다 지방자치 단체가 높다. 2021년 지방자치단체 문화예술부문 예산은 지방자치단체 총지출 263조 원 대비 $1.6 \%$ (4.1조원) 수준으로 동 기간 중앙정부 총지출 대비 문화예술부문 비중인 $0.7 \%$ (3.7조원)를 상회하는 규모이다.

〈표 4-15〉 지방자치단체와 중앙정부 문화예산 편성 추이(2011 2021)

(단위: \%, 조 원)

\begin{tabular}{|c|c|c|c|c|c|c|c|c|c|c|c|c|}
\hline \multicolumn{2}{|c|}{ 구분 } & \multirow{2}{*}{\begin{tabular}{|c|}
$' 11$ \\
141.0 \\
\end{tabular}} & \multirow{2}{*}{$\begin{array}{c}' 12 \\
151.1 \\
\end{array}$} & \multirow{2}{*}{\begin{tabular}{|c|}
13 \\
156.9 \\
\end{tabular}} & \multirow{2}{*}{\begin{tabular}{|c|}
$' 14$ \\
163.6 \\
\end{tabular}} & \multirow{2}{*}{\begin{tabular}{|c|}
15 \\
173.3 \\
\end{tabular}} & \multirow{2}{*}{\begin{tabular}{|c|c}
16 \\
184.6 \\
\end{tabular}} & \multirow{2}{*}{\begin{tabular}{|c|}
17 \\
193.2 \\
\end{tabular}} & \multirow{2}{*}{$\begin{array}{c}18 \\
210.7\end{array}$} & \multirow{2}{*}{\begin{tabular}{|c|}
\multicolumn{1}{c}{19} \\
231.0 \\
\end{tabular}} & \multirow{2}{*}{$\begin{array}{c}20 \\
253.2 \\
\end{array}$} & \multirow{2}{*}{$\begin{array}{c}21 \\
263.1\end{array}$} \\
\hline \multirow{9}{*}{ 지자체 } & 총지출 & & & & & & & & & & & \\
\hline & \multirow{2}{*}{ 문화및관광 } & 7.0 & 7.4 & 7.8 & 8.0 & 8.6 & 9.0 & 9.8 & 10.3 & 11.0 & 12.1 & 12.0 \\
\hline & & \begin{tabular}{|l|}
$(5.0)$ \\
\end{tabular} & $(4.9)$ & $(5.0)$ & $(4.9)$ & $(5.0)$ & $(4.9)$ & $(5.1)$ & $(4.9)$ & $(4.8)$ & $(4.8)$ & $(4.6)$ \\
\hline & \multirow{2}{*}{ 문화예술 } & 2.1 & 2.2 & 2.3 & 2.4 & 2.5 & 2.8 & 3.1 & 3.4 & 3.7 & 4.1 & 4.1 \\
\hline & & \begin{tabular}{|l|}
$(1.5)$ \\
\end{tabular} & (1.5) & $(1.5)$ & (1.5) & $(1.4)$ & $(1.5)$ & $(1.6)$ & (1.6) & (1.6) & (1.6) & (1.6) \\
\hline & 관광 & 1.2 & 1.3 & 1.3 & 1.2 & 1.3 & 1.4 & 1.6 & 1.7 & 1.7 & 1.9 & 1.9 \\
\hline & 체육 & 2.8 & 3.0 & 3.2 & 3.4 & 3.7 & 3.5 & 3.6 & 3.6 & 3.8 & 4.3 & 4.2 \\
\hline & 문화재 & 0.6 & 0.7 & 0.7 & 0.7 & 0.8 & 0.9 & 0.9 & 1.1 & 1.1 & 1.3 & 1.2 \\
\hline & 문화 및 관광일반 & 0.3 & 0.3 & 0.3 & 0.3 & 0.3 & 0.4 & 0.6 & 0.5 & 0.6 & 0.6 & 0.6 \\
\hline \multirow{9}{*}{$\begin{array}{l}\text { 중앙 } \\
\text { 정부 }\end{array}$} & 총지출 & 309.1 & 325.4 & 342.0 & 355.8 & 375.4 & 386.4 & 400.5 & 428.8 & 469.6 & 512.3 & 558.0 \\
\hline & \multirow{2}{*}{ 문화및관광 } & 4.2 & 4.6 & 5.0 & 5.4 & 6.1 & 6.6 & 6.9 & 6.5 & 7.2 & 8.0 & 8.5 \\
\hline & & (1.4) & (1.4) & $(1.5)$ & (1.5) & $(1.6)$ & $(1.7)$ & $(1.7)$ & (1.5) & (1.5) & (1.6) & (1.5) \\
\hline & \multirow{2}{*}{ 문화예술 } & 1.7 & 1.9 & 2.0 & 2.2 & 2.4 & 2.6 & 2.7 & 2.7 & 3.1 & 3.5 & 3.7 \\
\hline & & \begin{tabular}{|l|}
$(0.5)$ \\
\end{tabular} & $(0.6)$ & $(0.6)$ & $(0.6)$ & $(0.6)$ & $(0.7)$ & $(0.7)$ & $(0.6)$ & $(0.7)$ & $(0.7)$ & $(0.7)$ \\
\hline & 관광 & 0.9 & 1.0 & 1.1 & 1.2 & 1.4 & 1.4 & 1.6 & 1.4 & 1.4 & 1.3 & 1.5 \\
\hline & 체육 & 0.8 & 0.9 & 1.1 & 1.0 & 1.4 & 1.5 & 1.5 & 1.2 & 1.5 & 1.7 & 1.8 \\
\hline & 문화재 & 0.5 & 0.6 & 0.6 & 0.6 & 0.7 & 0.7 & 0.8 & 0.8 & 0.9 & 1.1 & 1.1 \\
\hline & 문화 및 관광일반 & 0.2 & 0.3 & 0.3 & 0.3 & 0.3 & 0.3 & 0.3 & 0.4 & 0.4 & 0.3 & 0.4 \\
\hline
\end{tabular}

주: 당초예산, 순계기준

자료: 지방재정통합공개시스템. 열린재정(재정정보공개시스템)

지방자치단체의 문화예술, 관광, 체육, 문화재, 문화 및 관광일반 부문을 포괄하고 있는 '문화 및 관광' 분야 예산 비중은 지난 10 년간 감소하는 추세이나 문화예술 부문 은 소규모이지만 점진적으로 비중을 늘려가고 있다. 지방자치단체 총지출대비 문화예 술부문 비중은 2011년 1.5\%에서 2021년 1.6\%로 증가하였고 동 기간 상위 분야인 문 화 및 관광분야는 2011년 5\%에서 2021년 4.6\%로 감소하였다. 문화예술부문이 소규 모이지만 점진적으로 비중을 늘려가는 추세는 중앙정부도 마찬가지다. 
2021년 기준 지방자치단체 문화 및 관광분야 $39.7 \%$, 문화예술부문의 30\%는 상급기관 으로부터 재원을 보조받는 보조사업으로 구성되어 있고, 이는 지방자치단체 전체 보조사 업 비중(46.1\%)보다 작은 규모이다. 재정지출 분야별 보조사업 비중이 크게 다르며, 지방 자치단체 평균 보조사업 비중보다 높은 분야는 사회복지 보조사업 $90.8 \%$, 보건 보조사업 $71.5 \%$, 농림해양수산 보조사업 $68.5 \%$, 산업·중소기업 및 에너지 보조사업 $50 \%$ 이다.

〈표 4-16〉지방자치단체 재정활동별 비중(2021년)

(단위: 억 원, \%)

\begin{tabular}{c|c|c|c|c|c|c|c}
\hline \multirow{2}{*}{ 구분 } & \multicolumn{2}{|c}{ 총지출 } & \multicolumn{5}{c}{ 재정 활동별 비중 } \\
\cline { 2 - 8 } & 규모 & 비중 & 합계 & $\begin{array}{c}\text { 보조 } \\
\text { 사업 }\end{array}$ & $\begin{array}{c}\text { 자체 } \\
\text { 사업 }\end{array}$ & $\begin{array}{c}\text { 재무 } \\
\text { 활동 }\end{array}$ & $\begin{array}{c}\text { 행정운영 } \\
\text { 경비 }\end{array}$ \\
\hline 일반공공행정 & 134,496 & 5.1 & 100.0 & 6.8 & 78.4 & 14.8 & - \\
\hline 공공질서및안전 & 52,800 & 2.0 & 100.0 & 38.6 & 42.9 & 18.5 & - \\
\hline 교육 & 140,329 & 5.3 & 100.0 & 5.1 & 92.6 & 2.2 & - \\
\hline 문화 및 관광 & 119,744 & 4.6 & 100.0 & 39.7 & 57.2 & 3.1 & - \\
\hline 문화예술 & 40,910 & 1.6 & 100.0 & 30.0 & 67.8 & 2.3 & - \\
\hline 관광 & 18,993 & 0.7 & 100.0 & 46.3 & 53.0 & 0.7 & - \\
\hline 체육 & 42,063 & 1.6 & 100.0 & 37.0 & 58.6 & 4.4 & - \\
\hline 문화재 & 12,235 & 0.5 & 100.0 & 77.9 & 21.9 & 0.2 & - \\
\hline 문화 및 관광 일반 & 5,543 & 0.2 & 100.0 & 25.8 & 60.7 & 13.5 & - \\
\hline 환경 & 263,631 & 10.0 & 100.0 & 39.2 & 56.2 & 4.7 & - \\
\hline 사회복지 & 804,767 & 30.6 & 100.0 & 90.8 & 8.9 & 0.3 & - \\
\hline 보건 & 44,091 & 1.7 & 100.0 & 71.5 & 28.4 & 0.1 & - \\
\hline 농림해양수산 & 172,441 & 6.6 & 100.0 & 68.5 & 29.4 & 2.0 & - \\
\hline 산업·중소기업 및 에너지 & 72,277 & 2.8 & 100.0 & 50.0 & 44.1 & 6.0 & - \\
\hline 교통 및 물류 & 209,007 & 7.9 & 100.0 & 27.3 & 64.7 & 8.0 & - \\
\hline 국토 및 지역개발 & 163,007 & 6.2 & 100.0 & 31.1 & 64.0 & 4.9 & - \\
\hline 과학기술 & 3,349 & 0.1 & 100.0 & 26.7 & 72.1 & 1.1 & - \\
\hline 예비비 & 39,518 & 1.5 & 100.0 & 0.5 & 99.0 & 0.5 & - \\
\hline 기타(인력운영비, 기본경비 등) & 411,461 & 15.6 & 100.0 & 0.0 & 14.0 & 0.4 & 85.6 \\
\hline 합계 & $2,630,917$ & 100.0 & 100.0 & 46.1 & 37.3 & 3.3 & 13.4 \\
\hline
\end{tabular}

주: 당초예산 순계 기준

자료: 행정안전부(2021), 2021년도 지방자치단체 통합재정 개요(상) 


\section{나. 지역별 문화예산 규모 및 재원 특징}

자치단체별 총지출 대비 문화예술부문 예산 비율은 경남(1.08\%)이 가장 낮고, 광주 (2.84\%)가 가장 높으며 평균 $1.55 \%$ 를 상회하는 지역은 광주, 울산, 세종, 부산, 대전, 전북, 대구, 제주, 강원, 경기 등이다. 평균보다 낮은 지역은 경남, 전남, 충남, 충북, 경 북, 서울, 인천 등이다. 서울과 인천을 제외하고 주로 광역도의 관할구역에 해당되는 지 역에 문화예술 예산 편성 비중이 낮게 나타났다.

다만 각 지역의 인구수를 고려한 1 인당 문화예술 예산(인구수 대비 자치단체 문화예 술 예산)은 서울(58,374원)이 가장 낮고 제주(144,825원)가 가장 높으며, 평균 78,932 원을 상회하는 지역은 제주, 강원, 전북, 광주, 전남, 경북, 세종, 울산, 충남, 충북, 부산 등이다. 평균보다 낮은 지역은 서울, 경기, 경남, 인천, 대구, 대전 등이다.

〈표 4-17〉 지방자치단체별 문화예술 예산 비율(2021년 기준)

(단위: 백만 원, \%, 명, 원)

\begin{tabular}{c|c|c|c|c|c}
\hline 자치단체 & $\begin{array}{c}\text { 총지출 } \\
(\mathrm{A}, \text { 백만원) }\end{array}$ & $\begin{array}{c}\text { 문화예술부문 지출 } \\
(\mathrm{B}, \text { 백만원) }\end{array}$ & $\begin{array}{c}\text { 인구 수 } \\
(\mathrm{C}, \text { 명 })\end{array}$ & $\begin{array}{c}\text { 문화예술예산 비율 } \\
(\mathrm{B} / \mathrm{A}, \%)\end{array}$ & $\begin{array}{c}\text { 1인당문화예술예산 } \\
\left(\mathrm{B} / \mathrm{C}^{*} \text { 백만원, 원) }\right.\end{array}$ \\
\hline 전국계 & $263,091,736$ & $4,090,973$ & $51,829,023$ & $1.55 \%$ & 78,932 \\
\hline 서울계 & $40,740,257$ & 564,386 & $9,668,465$ & $1.39 \%$ & 58,374 \\
\hline 부산계 & $14,415,991$ & 279,278 & $3,391,946$ & $1.94 \%$ & 82,336 \\
\hline 대구계 & $10,125,520$ & 178,556 & $2,418,346$ & $1.76 \%$ & 73,834 \\
\hline 인천계 & $13,307,454$ & 191,114 & $2,942,828$ & $1.44 \%$ & 64,942 \\
\hline 광주계 & $6,576,718$ & 186,868 & $1,450,062$ & $2.84 \%$ & 128,869 \\
\hline 대전계 & $6,015,945$ & 112,102 & $1,463,882$ & $1.86 \%$ & 76,579 \\
\hline 울산계 & $4,865,304$ & 109,140 & $1,136,017$ & $2.24 \%$ & 96,073 \\
\hline 세종계 & $1,665,747$ & 36,248 & 355,831 & $2.18 \%$ & 101,869 \\
\hline 경기계 & $51,454,732$ & 862,605 & $13,427,014$ & $1.68 \%$ & 64,244 \\
\hline 강원계 & $12,917,687$ & 223,118 & $1,542,840$ & $1.73 \%$ & 144,615 \\
\hline 충북계 & $10,250,433$ & 133,073 & $1,600,837$ & $1.30 \%$ & 83,127 \\
\hline 충남계 & $14,422,887$ & 185,444 & $2,121,029$ & $1.29 \%$ & 87,431 \\
\hline 전북계 & $13,989,775$ & 252,399 & $1,804,104$ & $1.80 \%$ & 139,903 \\
\hline 전남계 & $16,695,308$ & 191,573 & $1,851,549$ & $1.15 \%$ & 103,466 \\
\hline 경북계 & $20,110,469$ & 271,026 & $2,639,422$ & $1.35 \%$ & 102,684 \\
\hline 경남계 & $19,977,704$ & 216,341 & $3,340,216$ & $1.08 \%$ & 64,769 \\
\hline 제주계 & $5,559,804$ & 97,704 & 674,635 & $1.76 \%$ & 144,825 \\
\hline 제 & & & & \\
\hline
\end{tabular}

주: 1) 당초예산, 순계기준

2) 인구 수는 주민등록에 의한 집계, 외국인 제외

자료: 지방재정통합공개시스템, 행정안전부 주민등록 인구통계(2020년 말 기준) 
지방자치단체 유형별 세출비중을 살펴보면 문화예술은 광역시도와 자치시가 자치군, 자치구보다 상대적으로 세출비중이 높다.

〈표 4-18〉 지방자치단체 유형별/기능별(분야) 세출비중(2020년)

\begin{tabular}{|c|c|c|c|c|}
\hline 분야 & 광역시도 & 자치시 & 자치군 & 자치구 \\
\hline 일반공공행정 & 5.9 & 5.0 & 5.3 & 4.6 \\
\hline 공공질서및안전 & 2.9 & 0.9 & 2.2 & 0.6 \\
\hline 교육 & 14.1 & 1.8 & 0.9 & 1.3 \\
\hline 문화 및 관광 & 4.6 & 5.3 & 6.5 & 2.4 \\
\hline 문화예술 & 1.8 & 1.8 & 1.2 & 1.2 \\
\hline 관광 & 0.6 & 0.7 & 1.8 & 0.1 \\
\hline 체육 & 1.5 & 2.0 & 2.2 & 0.9 \\
\hline 문화재 & 0.4 & 0.5 & 1.0 & 0.1 \\
\hline 문화 및 관광 일반 & 0.3 & 0.2 & 0.3 & 0.1 \\
\hline 환경보호 & 8.9 & 13.9 & 10.4 & 4.3 \\
\hline 사회복지 & 20.9 & 30.7 & 21.4 & 52.4 \\
\hline 보건 & 1.0 & 1.7 & 1.8 & 2.2 \\
\hline 농림해양수산 & 2.9 & 6.5 & 18.3 & 0.6 \\
\hline 산업·중소기업 & 4.0 & 2.1 & 2.2 & 0.6 \\
\hline 수송 및 교통 & 13.6 & 6.9 & 4.4 & 4.0 \\
\hline 국토및지역개발 & 6.3 & 8.4 & 8.8 & 3.0 \\
\hline 과학기술 & 0.4 & 0.0 & 0.0 & 0.0 \\
\hline 예비비 & 1.1 & 2.6 & 2.0 & 1.2 \\
\hline 기타 & 13.5 & 14.2 & 15.7 & 22.8 \\
\hline 합계 & 100.0 & 100.0 & 100.0 & 100.0 \\
\hline
\end{tabular}

주: 당초예산, 순계기준

자료: 행정안전부(각년도), 지방자치단체 통합재정 개요(하)

지방자치단체의 예산 재원은 중앙정부가 부담하는 국비, 광역자치단체가 부담하는 시 도비, 그리고 기초자치단체에서 부담하는 시군구비로 구성된다. 2020년 지방자치단체 문화재정의 재원별 구성을 살펴보면 국비 $13.5 \%$ (1조 6,321억원), 시도비 33.5\%(4조 575 억원), 시군구비 53.0\%(6조 4,309억원)으로 기초단위로 갈수록 재원부담 비중이 높 아지는 것으로 나타났다. 
2010년과 비교해 보면 시군구비 비중은 7\%p 증가 $(2010$ 년 46\% $\rightarrow 2020$ 년 53\%)하 였고, 시도비는 $-5.7 \%$ p 감소(2010년 39.2\% $\rightarrow 2020$ 년 33.5\%), 국비는 $-1.3 \%$ p 감소 $(2010$ 년 $14.8 \% \rightarrow 2020$ 년 $13.5 \%)$ 하였다.

〈표 4-19〉 지방자치단체 문화재정 재원별 예산규모 추이(2010년 2020년)

\begin{tabular}{c|c|c|c|c|c|c|c|c}
\hline \multirow{2}{*}{ 년도 } & \multirow{2}{*}{ 합계 } & \multicolumn{2}{|c|}{ 국비 } & \multicolumn{2}{c|}{ 시도비 } & \multicolumn{2}{c}{ 시군구비 } & \multirow{2}{*}{ 기타 } \\
\cline { 3 - 8 } & & 예산액 & 구성비 & 예산액 & 구성비 & 옛산액 & 구성비 & \\
\hline 2010 & 77,949 & 11,502 & 14.8 & 30,555 & 39.2 & 35,888 & 46.0 & 4 \\
\hline 2011 & 69,872 & 11,711 & 16.8 & 24,341 & 34.8 & 33,820 & 48.4 & 0 \\
\hline 2012 & 74,441 & 12,270 & 16.5 & 26,749 & 35.9 & 35,422 & 47.6 & 0 \\
\hline 2013 & 78,408 & 13,744 & 17.5 & 27,153 & 34.6 & 37,510 & 47.8 & 0 \\
\hline 2014 & 79,981 & 14,001 & 17.5 & 27,685 & 34.6 & 38,281 & 47.9 & 14 \\
\hline 2015 & 86,489 & 15,214 & 17.6 & 31,473 & 36.4 & 39,788 & 46.0 & 14 \\
\hline 2016 & 90,403 & 17,121 & 18.9 & 28,950 & 32.0 & 44,322 & 49.0 & 11 \\
\hline 2017 & 98,145 & 16,565 & 16.9 & 32,278 & 32.9 & 49,294 & 50.2 & 9 \\
\hline 2018 & 102,866 & 14,121 & 13.7 & 33,210 & 32.3 & 55,435 & 53.9 & 99 \\
\hline 2019 & 110,233 & 15,832 & 14.4 & 35,935 & 32.6 & 58,369 & 53.0 & 97 \\
\hline 2020 & 121,263 & 16,321 & 13.5 & 40,575 & 33.5 & 64,309 & 53.0 & 5,7 \\
\hline
\end{tabular}

주: 당초예산, 순계기준

자료: 행정안전부(각 년도). 지방자치단체 통합재정 개요(하) 


\section{제2절 지역문화 성과협약형 포괄보조 대상 검토}

\section{1. 성과협약형 포괄보조 방식 적격성 검토 기준}

\section{가. 미국의 포괄보조 고려 기준 논의}

성과협약형 포괄보조금 지원제도를 도입하기 위해서는 먼저 어떤 사업이 포괄보조금 방식으로 적합한지를 검토하는 작업이 필요하다. 미국의 경우 1966년 최초의 포괄보조 사업 시행 이후, 정책분석자와 정책입안자들은 포괄보조를 시행하기 위한 가장 적절한 상황과 기존의 개별보조에서 포괄보조로 전환할 때 고려되어야 할 적절한 기준을 파악 하기 위해 노력해왔다.

지금은 해체된 미국의 정부 간 관계 위원회 ACIR(U.S. Advisory Commission on Intergovernmental Relations) 19$)$ 은 다음과 같은 4가지 기준으로 개별보조프로그램을 종료하거나 통합하는 것이 적절하다고 하였다. (1)개별 보조사업 규모가 너무 작아서 사 업의 영향이 없거나 관리비용을 들이는 가치가 현저히 낮은 경우, (2)프로그램이 본질적 으로 명확하게 국가적 목표를 나타내지 않는 경우, (3)프로그램 자금 대부분이 지방정부 로부터 발생하거나 민간으로 전환할 수 있는 경우, (4)다수의 프로그램이 동시에 존재하 는 영역(보건, 교육, 사회서비스 등) 또는 분할이 발생하고 있는 영역(법무, 천연자원, 산업보건 등)의 경우이다.

연방주의 학자들은 포괄보조 방식 고려 기준을 다음과 같이 4 가지로 정리하고 있다 (Jaroscak, Lawhorn and Dilger, 2020). (1)연방정부가 지방정부 관할 프로그램의 서 비스 수준을 보완할 필요가 있는 영역이나, (2)국가목표가 지방정부 목표와 일치하거나, (3)연방정부가 해당 지역에 전국적으로 최소 서비스 수준을 확립하려고 하거나, (4)지방 정부가 우선순위를 설정하고 프로그램을 관리하는 방법을 가장 잘 알고 있다고 연방정

19) 정부간 관계를 연구하기 위해 1959년에 설립된 기관으로 중앙정부와 지방정부를 대표하는 26 명의 인사 가 참여하는 형태로 유지되다가 1996년 해체되었음(GAO, 2014) 
부가 판단할(만족할) 경우이다.

미국에서의 포괄보조 방식 고려기준을 살펴보면, 정책의 성과는 국가목표와 지방목표 가 일치하면서 사업은 지역단위에서 보다 잘 관리할 수 있는 영역, 예산규모가 작아서 행정비용 대비 정책효과가 잘 드러나지 않는 영역, 유사·중복성이 높은 사업영역을 제시 하고 있다.

〈표 4-20〉포괄보조 방식 고려 기준

\begin{tabular}{|c|c|}
\hline 정부간 관계위원회(ACIR) 기준 & 연방주의 학자 기준 \\
\hline $\begin{array}{l}\text { (1) 개별 보조사업 규모가 너무 작아서 사업의 영향이 } \\
\text { 없거나 관리비용을 들이는 가치가 현저히 낮은 경 } \\
\text { 우 } \\
\text { (2) 프로그램이 본질적으로 명확하게 국가적 목표를 나 } \\
\text { 타내지 않는 경우 } \\
\text { (3) 프로그램 자금 대부분이 지방정부로부터 발생하거 } \\
\text { 나 민간으로 전환할 수 있는 경우 } \\
\text { (4) 다수의 프로그램이 동시에 존재하는 영역(보건, 교 } \\
\text { 육, 사회서비스 등) 또는 분할이 발생하고 있는 영 } \\
\text { 역(법무, 천연자원, 산업보건 등)의 경우 }\end{array}$ & $\begin{array}{l}\text { (1) 연방정부가 전통적으로 주 및 지방 관할 하에 제공 } \\
\text { 되는 특정 광범위한 프로그램 영역에서 서비스 수 } \\
\text { 준을 보완하고자 할 경우 } \\
\text { (2) 광범위한 국가 목표가 주 및 지방 프로그램 목표와 } \\
\text { 일치하는 경우 } \\
\text { (3) 연방정부가 해당 지역에서 전국적인 최소 서비스 } \\
\text { 수준을 확립하려고 할 경우 } \\
\text { (4) 연방 정부가 하위 우선 순위를 설정하고 프로그램 } \\
\text { 을 관리하는 방법을 주 및 지방 정부가 가장 잘 알 } \\
\text { 고 있다고 만족할 경우 }\end{array}$ \\
\hline
\end{tabular}

가료: Jaroscak, Lawhorn and Dilger(2020), Block Grants: Perspectives and Controversies

\section{나. 국내의 포괄보조 적합 대상 기준 논의}

국내에서는 복지 및 농림 분야에서는 포괄보조에 적합한 대상사업을 선정하기 위한 몇 가지 기준을 제시하였고(정은희 외, 2014; 조재환-이한성, 2013), 이는 다음과 같이 4가지로 정리할 수 있다. (1)소규모 유사·중복 사업, (2)사업시행효과의 지역성이 높은 사업, (3)성과지표 산출이 용이한 사업, (4)법정공식 적용이 용이한 사업이다. 포괄보조 제도가 미국에서의 정책 경험이 선행되었던 영향으로 대체로 국내에서 포괄보조 사업의 판단기준은 미국에서 고려하는 사항과 비슷하다. 다만 국내에서 제시한 기준은 미국보다 구체적으로 성과지표의 산출 용이성과 법정공식 적용이 용이한 사업으로 성과관리의 구 체화와 재정배분에 대한 기준까지 제시하고 있다.

그렇다면 반대로 포괄보조금이 아닌 개별보조금 방식 혹은 국가 직접추진 방식이 보 다 적합한 사업은 다음과 같이 정리할 수 있다. 국가사무 성격이 강하고 사업시행 효과 가 전국에 걸쳐 발생하는 경우 개별보조사업 방식이나 중앙정부 직접추진 방식이 적절 
하다. 표준화된 서비스 및 품질관리, 국제교류 및 수출지원, 기초연구 및 정보화사업 등 이 해당될 수 있다. 그리고 대규모 예산사업은 현행 국고보조금 지원방식으로 유지하는 것이 보다 적절하다. 대규모 예산사업은 소요기간이 장기간 요구되고 대응지방비의 과다 지출로 지방자치단체 의 재정건전성에도 부정적인 영향을 미칠 수 있기 때문이다.

\section{다. 성과협약형 포괄보조 방식 적격성 검토 기준}

성과협약형 포괄보조 방식 적격성 검토 기준은 기존 연구를 종합하여 공통적으로 적 용되고 있는 다음 4 가지를 고려하여 판단하고자 한다.

첫째 사업의 정책 및 재정관리 특성이다. 소액의 국고보조사업 중 사업성격이 유사하 거나 중복되는 사업은 포괄보조금으로 전환이 가장 용이한 사업들로서 중앙정부의 관련 부서 간 조정이 용이하고 포괄보조방식으로의 전환에 대해 지방자치단체의 저항 또한 가장 적을 수 있다. 더불어 성과관리에서 지방자치단체 자체사업과 연계성이 높은 사업 으로, 세부사업계획과 집행관리에서 지자체 재량 확대를 통해 분권혁신효과(재정절감, 성과확대 등)를 기대할 수 있다.

둘째, 자치단체 자율성 보장과 사업시행효과의 지역성이 높은 사업이다. 국고보조사 업 중 지방자치단체 고유업무적 성격이 강하고 지방자치단체가 주체가 되어 사업을 추 진하려는 유인이 큰 사업일수록 포괄보조금 지원방식으로의 전환은 자치단체의 자율성 을 높이고 재정사업의 성과창출을 기대할 수 있다. 자치단체가 주체가 되어 추진하려는 사업일수록 사업발굴 및 계획수립에 자치단체 상위계획을 연계하려는 효과를 기대할 수 있기 때문이다. 외부효과가 작고 지방자치단체 의 책임성이 강조되는 사업이 적절하다.

셋째, 성과지표 산출이 용이한 사업이다. 예산을 포괄적으로 지원하는 방식은 기획 및 집행의 자율성과 재량을 허용하는 대신 성과와 재정책임을 강조해야 한다. 특히 정부의 재정운용 방식이 투입 중심의 통제지향에서 산출 중심의 성과지향으로 바뀌고 있으므로 포괄보조금 지원방식에 적합한 성과측정이 가능한 사업을 우선 고려해야 한다. 지방자치 단체 의 개별 사업운영 결과와 중앙정부 소관부서의 성과계획의 연계가 용이하게 형성 될 수 있는 사업들이 적합하다.

마지막으로 재원배분의 객관적 기준 설정 용이한 사업이다. 지원기준 및 재원배분과 관련하여 객관적이고 공정한 공식에 기반을 둘 수 있는 사업을 대상으로 포괄보조 방식 
을 고려할 필요가 있다. 과거 재정지출 추세를 고려할 때, 지방자치단체 별 연차별 재원 배분 규모의 예측성과 안정성이 높고 미래 재정수요를 전망할 때, 지방자치단체 혹은 지역단위별로 사업의 재정지출 수요가 객관적으로 예측가능하고 안정적인 사업이 이에 해당된다. 이 경우 지방자치단체는 재정확보 가능성을 예측하여 불확실성을 사전에 제거 하고 계획 하에 안정적인 사업 추진이 가능할 것이다.

〈표 4-21〉 포괄보조 대상사업 적합성

\begin{tabular}{|c|c|}
\hline 기준 & 내용 \\
\hline $\begin{array}{l}\text { 사업의 정책 및 } \\
\text { 재정관리 특성 }\end{array}$ & $\begin{array}{l}\text { - 소관부처 내 부서간 저항을 조정하기가 쉬운 영세 보조금 사업 } \\
\text { - 사업성격이 유사하거나 중복되는 사업으로 통합효과가 높은 사업 } \\
\text { - 성과관리에서 지자체 자체사업과 연계성이 높은 사업 } \\
\text { - 세부사업계획과 집행관리에서 지자체 재량 확대를 통해 분권혁신효과 } \\
\quad \text { (재정절감, 성과확대 등)가 기대되는 사업 }\end{array}$ \\
\hline 사업 시행효과의 지역성 & $\begin{array}{l}\text { - 자치단체 고유 업무성격이 강한 사업 } \\
\text { - 자치단체가 실질적인 주체로 활동하는 사업 } \\
\text { - 편익범위나 외부성이 자치단체 지역에 한정되는 국지적인 사업 }\end{array}$ \\
\hline 성과지표 산출의 용이성 & $\begin{array}{l}\text { - 고용, 소득, 생산성, 주민 만족도 등 성과측정이 용이한 사업 } \\
\text { - 국가와 자치단체 간 공통의 성과지표 개발이 용이한 사업 }\end{array}$ \\
\hline $\begin{array}{c}\text { 재원배분의 } \\
\text { 객관적 기준 설정 용이 }\end{array}$ & $\begin{array}{l}\text { - 과거 재정지출 추세를 고려할 때, 지자체별 연차별 재원배분 규모의 예측 } \\
\text { 성과 안정성이 높은 사업 } \\
\text { - 미래 재정수요를 전망할 때, 지자체 혹은 지역단위별로 사업의 재정지출 } \\
\text { 수요가 객관적으로 예측가능하고 안정적인 사업 } \\
\text { - 법적 공식주의 운용 및 이에 필요한 통계자료의 이용가능성 }\end{array}$ \\
\hline
\end{tabular}




\section{2. 성과협약형 포괄보조 방식 적격성 검토 결과}

본 연구는 2021년 문화체육관광부 문화예술정책실 소관 48개 세부사업 184 개 내역 사업에 대한 성과협약형 포괄보조 방식에 적격성을 검토하였고, 사업의 성격을 검토하기 때문에 지방자치단체 보조와 민간보조를 모두 포함하고 있다. 다만 아시아문화중심도시 조성 특별회계 사업과 국가균형발전특별회계 지역자율계정 사업은 본 분석에서 제외하 였다. 아시아문화중심도시 조성 사업비 확보를 위한 재원으로 해당 사업은 지리적으로 특정 지방자치단체(광주광역시)에 한정되어 있기 때문이다. 그리고 균특회계 지역자율계 정은 지방자치단체 예산실링 한도 내에서 자율적인 사업을 추진하는 포괄보조형 재원이 기 때문이다.

분야-부문프로그램-단위사업-세부사업으로 이어지는 프로그램 예산체계에서 가장 하부는 세부사업이지만, 문화체육관광부는 사업의 특성상 세부사업의 명세를 나타내는 내역사업 단위에서 성질이 다른 사업들이 있다. 따라서 본 연구에서 검토기준 예산단위 는 실제 사업내용을 모두 파악하고 분류할 수 있는 내역사업 단위까지 검토하였다.

\section{가. 전통생활문화 분야}

전통생활문화분야는 유사기능별 사업군을 묶고 자치단체 고유 업무성격이 강한 사업 을 합하여 포괄보조화 한 제안으로, '전통생활문화 활성화 지원' , '전통놀이문화 조성 및 확산', ‘세시풍속 맥 잇기', ‘디지털 생활사 아카이빙 사업’을 하나의 전통생활문화 포괄 보조대상으로 한다.

현재의 전통생활문화 지원이나 전통놀이, 세시풍속, 디지털생활사 등의 내용은 지역 을 기반으로 한 생활문화인 전통적 관습과 풍속, 향토문화 자원 등을 수집, 관리, 상품화 및 디지털화하는 것으로 지역의 고유성이 중시되는 영역이다. 지방문화, 전통생활문화, 생활사 등의 용어를 사용하고 현재는 소관 부서도 다르지만 실질적인 사업 내용은 각 지역의 풍습, 유래, 놀이 등 전통생활문화의 수집, 관리, 사업화라 할 수 있다. 
〈표 4-22〉 전통생활문화 분야 포괄보조사업 제안

(단위: 백만원)

\begin{tabular}{|c|c|c|c|c|}
\hline 단위사업 & 세부사업 & 내역사업 & 비고 & 예산 \\
\hline \multirow{7}{*}{$\begin{array}{l}\text { 전통생활 } \\
\text { 문화 진흥 }\end{array}$} & \multirow{7}{*}{$\begin{array}{l}\text { 전통생활 } \\
\text { 문화 진흥 }\end{array}$} & ○전통생활문화 활성화 지원 & $\begin{array}{l}\text { 전통서당문화, 풍석학술진흥연구, 전통 } \\
\text { 문화인성교육 등 }\end{array}$ & 1,799 \\
\hline & & O전통놀이문화 조성 및 확산 & 전통놀이 콘텐츠 개발보급 & 1,605 \\
\hline & & 에종문화상 시상금 & 개인이나 단체에 세종문화상 포상 & 179 \\
\hline & & O남북한 전통문화 교류 & $\begin{array}{l}\text { 남북한 간 한복, 한식 등의 조사, 연구, } \\
\text { 교류 }\end{array}$ & 50 \\
\hline & & $\begin{array}{l}\text { ○한국문화원형 콘텐츠체험 및 } \\
\text { 전시관 건립 }\end{array}$ & - & 700 \\
\hline & & ㅇ세시풍속 맥 잇기 & $\begin{array}{l}\text { 지역 세시풍속 공모·선정·지원 및 개선 } \\
\text { 컨설팅 }\end{array}$ & 170 \\
\hline & & O전통문화 해외거점 조성 & $\begin{array}{l}\text { 재외한국문화원 내 전통문화 전시 및 체 } \\
\text { 험 공간 구축 }\end{array}$ & 700 \\
\hline \multirow{7}{*}{$\begin{array}{l}\text { 지역문화 } \\
\text { 진흥 }\end{array}$} & \multirow{7}{*}{$\begin{array}{l}\text { 지역문화 } \\
\text { 진흥 }\end{array}$} & 지역문화역량 강화 & $\begin{array}{l}\text { 지역문화전문인력양성·배치, 지역문화재 } \\
\text { 단 역량강화, 문화의 달 기념행사 등 }\end{array}$ & 3,306 \\
\hline & & ○한국문화원연합회 지원 & 지방문화원 역량강화 네트워크, 운영비 등 & 2,126 \\
\hline & & O생활문화 활성화 & $\begin{array}{l}\text { 생활문화센터 지원, 문화자원봉사 사회 } \\
\text { 확산 지원 등 }\end{array}$ & 1,400 \\
\hline & & O지역문화 활동가 지원 & 지역문화활동가 문화프로그램 지원 & 300 \\
\hline & & O실버문화페스티벌 지원 & 행사지원 & 1,060 \\
\hline & & ○지방문화원 원천콘텐츠 발굴 & $\begin{array}{l}\text { 지역문화콘텐츠개발사업, 지방문화원 소 } \\
\text { 장자료 디지털화 }\end{array}$ & 5,693 \\
\hline & & O디지털 생활사 아카이빙 사업 & $\begin{array}{l}\text { 생활사기록가 모집 및 양성, 구술 및 채 } \\
\text { 록활동 지원 }\end{array}$ & 900 \\
\hline
\end{tabular}

지방자치단체 입장에서는 지역의 정체성과 향토문화 보존 차원에서 해당 사업영역을 지방자치단체 주요 사업으로 적극 추진할 여지가 높다. 지역의 역사적, 문화적, 생활사 적 특성에 따라 중요하게 여기는 가치를 수집, 관리, 활성화, 사업화라는 사업을 기획할 수 있고, 전통생활문화에 대한 인식도, 전통생활사 애착도, 전통생활상품 사업화 실적 등을 성과지표로 적용할 수 있다.

〈표 4-23〉 전통생활문화 분야 포괄보조사업 적격성 검토

\begin{tabular}{|c|c|c|c|c|}
\hline 구분 & 소액·유사성 & 지역성 & 성과지표 적용 & 예산배정 기준 \\
\hline ○전통생활문화 활성화 지원 & () & () & $\triangle$ & $\triangle$ \\
\hline О전통놀이문화 조성 및 확산 & (2) & () & $\triangle$ & $\triangle$ \\
\hline 에시풍속 맥 잇기 & (0) & () & $\triangle$ & $\triangle$ \\
\hline 으디지털 생활사 아카이빙 사업 & () & (2) & $\triangle$ & 0 \\
\hline
\end{tabular}

주: () 매우높음, $\bigcirc$ 높음, $\triangle$ 보통, $\times$ 없음 


\section{나. 지역문화 활동인력 지원 분야}

지역문화 활동인력 지원분야는 지역의 문화전문 인력이라는 명확한 대상에 초점을 두 고 사업군을 묶고 지역 내 일자리 수요가 있기 때문에 자치단체 차원에서 인적자원 관리 가 필요한 영역으로 관련 사업을 합하여 포괄보조화 한 제안이다. 내역사업 기준 '이야 기할머니 인력양성 및 활동지원', ‘인생나눔교실 운영', ‘지역문화예술교육 지원', ‘문화 예술교육 전문인력양성', '지역문화역량 강화', '지역문화 활동가 지원'을 하나의 지역문 화활동인력 지원 포괄보조 대상으로 한다.

〈표 4-24〉지역문화 활동인력 지원 분야 포괄보조사업 제안

(단위: 백만원)

\begin{tabular}{|c|c|c|c|c|}
\hline 단위사업 & 세부사업 & 내역사업 & 비고 & 예산 \\
\hline \multirow{6}{*}{$\begin{array}{l}\text { 문화·인문 } \\
\text { 진흥 }\end{array}$} & \multirow{6}{*}{$\begin{array}{l}\text { 인문정신문화 } \\
\text { 사회적 확산 } \\
\text { 지원 }\end{array}$} & 길ㄹ위의 인문학 & \begin{tabular}{|l|} 
도서관, 박물관, 생활문화시설 \\
등에서 인문강연 프로그램
\end{tabular} & 11,499 \\
\hline & & ○인문정신문화 온라인서비스 제공 & - & 972 \\
\hline & & 인생나눔교실 운영 & $\begin{array}{l}\text { 만 50세 이상의 은퇴세대의 } \\
\text { 멘토링 및 나눔활동 지원 }\end{array}$ & 3,300 \\
\hline & & 인문실태조사 & - & 100 \\
\hline & & ㅇ2세기 인문가치 포럼 & $\begin{array}{l}\text { '14년부터 매년 경북 안동에서 } \\
\text { 국제포럼 개최 }\end{array}$ & 300 \\
\hline & & 이지털 인문 뉴딜 & $\begin{array}{l}\text { 디지털 지역인문자원 발굴 및 } \\
\text { B2B B2C 지원 }\end{array}$ & 740 \\
\hline $\begin{array}{l}\text { 전통문화 } \\
\text { 진흥 }\end{array}$ & $\begin{array}{l}\text { 전통스토리 } \\
\text { 계승 및 활용 }\end{array}$ & $\begin{array}{l}\text { 이야기할머니 인력양성 및 } \\
\text { 활동지원 }\end{array}$ & $\begin{array}{l}\text { 할머니(56세 80세)가 어린이 } \\
\text { 집 방문, 유아(3세-6세) 대상 } \\
\text { 으로 전통 이야기 교육 }\end{array}$ & 12,414 \\
\hline \multirow{6}{*}{$\begin{array}{l}\text { 문화예술 } \\
\text { 교육지원 }\end{array}$} & \multirow{6}{*}{$\begin{array}{l}\text { 문화예술교육 } \\
\text { 활성화 }\end{array}$} & ○학교 문화예술교육 지원 & $\begin{array}{l}\text { 초중고 학교 예술강사, 유아 } \\
\text { 문화예술교육프로그램 지원 }\end{array}$ & 59,094 \\
\hline & & 아회문화예술교육 지원 & $\begin{array}{l}\text { 소외지역 및 특수계층 대상 } \\
\text { 문화예술교육프로그램 제공 }\end{array}$ & 41,132 \\
\hline & & 이역문화예술교육 지원 & $\begin{array}{l}\text { 지역문화예술교육지원센터 } \\
\text { 교육기반 구축 지원 }\end{array}$ & 18,245 \\
\hline & & O문화예술교육 전문인력 양성 & $\begin{array}{l}\text { 문화예술교육 전문인력양성 및 } \\
\text { 재교육 총괄 }\end{array}$ & 1,710 \\
\hline & & ○한국문화예술교육진흥원 지원 & - & 9,740 \\
\hline & & O온라인 문화예술교육 지원 & - & 2,000 \\
\hline
\end{tabular}




\begin{tabular}{|c|c|c|c|c|}
\hline 단위사업 & 세부사업 & 내역사업 & 비고 & 예산 \\
\hline \multirow{7}{*}{$\begin{array}{l}\text { 지역문화 } \\
\text { 진흥 }\end{array}$} & \multirow{7}{*}{ 지역문화진흥 } & 이역문화역량 강화 & $\begin{array}{l}\text { 지역문화전문인력양성·배치, } \\
\text { 지역문화재단 역량강화, 문화의 } \\
\text { 달 기념행사 등 }\end{array}$ & 3,306 \\
\hline & & ○한국문화원연합회 지원 & $\begin{array}{l}\text { 지방문화원 역량강화 네트워 } \\
\text { 크, 운영비 등 }\end{array}$ & 2,126 \\
\hline & & O생활문화 활성화 & \begin{tabular}{|l|} 
생활문화센터 지원, 문화자원 \\
봉사 사회확산 지원 등
\end{tabular} & 1,400 \\
\hline & & ○지역문화 활동가 지원 & $\begin{array}{l}\text { 지역문화활동가 문화프로그램 } \\
\text { 지원 }\end{array}$ & 300 \\
\hline & & O실버문화페스티벌 지원 & 행사지원 & 1,060 \\
\hline & & ○지방문화원 원천콘텐츠 발굴 & \begin{tabular}{|l|} 
지역문화콘텐츠개발사업, \\
지방문화원 소장자료 디지털화
\end{tabular} & 5,693 \\
\hline & & ㄷ디지털 생활사 아카이빙 사업 & \begin{tabular}{l|} 
생활사기록가 모집 및 양성, \\
구술 및 채록활동 지원
\end{tabular} & 900 \\
\hline
\end{tabular}

지방자치단체는 지역의 문화수요 특성과 노동시장 실정에 맞게 인력을 교육하고 일자 리에 연계하여 배치할 수 있고, 활동률, 취업률, 재교육률 등의 성과지표를 적용할 수 있다. 그리고 17 개 시·도 지역문화예술교육 지원센터, 문화예술위원회 등과 연계하여 지역 문화 활동인력(기획자, 활동가, 예술인 등)을 대상으로 교육 및 역량강화 계획을 지방자치단체가 독자적으로 수립할 수 있다. 문화체육관광부는 지역문화활동인력 정보 통합관리와 함께 교육인력 혹은 관리인력 대비 예산을 산정할 수 있고, 지방자치단체별 배분기준은 인구, 면적 등에 가중치를 둘 수 있다.

〈표 4-25〉 지역문화 활동인력 분야 포괄보조사업 적격성 검토

\begin{tabular}{|c|c|c|c|c|}
\hline 구분 & 소액·유사성 & 지역성 & 성과지표 적용 & 예산배정 기준 \\
\hline 인생나눔교실 운영 & $\bigcirc$ & $\bigcirc$ & (0) & (0) \\
\hline 이야기할머니 인력양성 및 활동지원 & $\triangle$ & 0 & (0) & () \\
\hline O지역문화예술교육 지원 & 0 & (0) & (0) & (0) \\
\hline ○문화예술교육 전문인력 양성 & (0) & (0) & (0) & () \\
\hline 이역문화역량 강화 & 0 & (0) & (0) & () \\
\hline 지역문화 활동가 지원 & (0) & (2) & (2) & () \\
\hline
\end{tabular}

주: () 매우높음, $\bigcirc$ 높음, $\triangle$ 보통, $\times$ 없음 


\section{다. 지역 문화서비스 지원 분야}

지역 문화서비스 지원 분야는 지역의 인구구성, 생활특성애 따라 주민의 문화서비스 선호 및 욕구가 다르기 때문에 자치단체 차원에서 지역의 특성을 반영하여 세부계획을 세울 수 있도록 지역민을 대상으로 하는 문화서비스 관련 사업을 합하여 포괄보조화 한 제안이다. 내역사업 기준 '길 위의 인문학' '사회문화예술교육 지원', '생활문화 활성화', '실버문화페스티벌지원', ‘어르신문화프로그램운영'을 하나의 '지역 문화서비스 지원' 포 괄보조 대상으로 한다.

〈표 4-26〉지역 문화서비스 지원 분야 포괄보조사업 제안

\begin{tabular}{|c|c|c|c|c|}
\hline 단위사업 & 세부사업 & 내역사업 & 비고 & 예산 \\
\hline \multirow{6}{*}{$\begin{array}{l}\text { 문화·인문 } \\
\text { 진흥 }\end{array}$} & \multirow{6}{*}{$\begin{array}{c}\text { 인문정신문화 } \\
\text { 사회적 확산 지원 }\end{array}$} & ○길위의 인문학 & $\begin{array}{l}\text { 도서관, 박물관, 생활문화시설 } \\
\text { 등에서 인문강연 프로그램 }\end{array}$ & 11,499 \\
\hline & & $\begin{array}{l}\text { 인문정신문화 온라인서비스 } \\
\text { 제공 }\end{array}$ & - & 972 \\
\hline & & ○인생나눔교실 운영 & $\begin{array}{l}\text { 만 50세 이상의 은퇴세대의 } \\
\text { 멘토링 및 나눔활동 지원 }\end{array}$ & 3,300 \\
\hline & & 인ㄴ문실태조사 & - & 100 \\
\hline & & ㅇ2세기 인문가치 포럼 & $\begin{array}{l}\text { '14년부터 매년 경북 안동에서 } \\
\text { 국제포럼 개최 }\end{array}$ & 300 \\
\hline & & 이지털 인문 뉴딜 & $\begin{array}{l}\text { 디지털 지역인문자원 발굴 및 } \\
\text { B2B B2C 지원 }\end{array}$ & 740 \\
\hline \multirow{6}{*}{$\begin{array}{l}\text { 문화예술 } \\
\text { 교육지원 }\end{array}$} & \multirow{6}{*}{$\begin{array}{l}\text { 문화예술교육 } \\
\text { 활성화 }\end{array}$} & ○학교 문화예술교육 지원 & $\begin{array}{l}\text { 초중고 학교 예술강사, 유아 } \\
\text { 문화예술교육프로그램 지원 }\end{array}$ & 59,094 \\
\hline & & 아회문화예술교육 지원 & $\begin{array}{l}\text { 소외지역 및 특수계층 대상 } \\
\text { 문화예술교육프로그램 제공 }\end{array}$ & 41,132 \\
\hline & & 이역문화예술교육 지원 & $\begin{array}{l}\text { 지역문화예술교육지원센터 } \\
\text { 교육기반 구축 지원 }\end{array}$ & 18,245 \\
\hline & & ○문화예술교육 전문인력 양성 & $\begin{array}{l}\text { 문화예술교육 전문인력양성 및 } \\
\text { 재교육 총괄 }\end{array}$ & 1,710 \\
\hline & & ○한국문화예술교육진흥원 지원 & - & 9,740 \\
\hline & & ○온라인 문화예술교육 지원 & - & 2,000 \\
\hline $\begin{array}{l}\text { 지역문화 } \\
\text { 진흥 }\end{array}$ & 지역문화진흥 & ○지역문화역량 강화 & $\begin{array}{l}\text { 지역문화전문인력양성·배치, } \\
\text { 지역문화재단 역량강화, 문화의 } \\
\text { 달 기념행사 등 }\end{array}$ & 3,306 \\
\hline
\end{tabular}




\begin{tabular}{|c|c|c|c|c|}
\hline 단위사업 & 세부사업 & 내역사업 & 비고 & 예산 \\
\hline & & O한국문화원연합회 지원 & $\begin{array}{l}\text { 지방문화원 역량강화 네트워 } \\
\text { 크, 운영비 등 }\end{array}$ & 2,126 \\
\hline & & ○생활문화 활성화 & $\begin{array}{l}\text { 생활문화센터 지원, 문화자원 } \\
\text { 봉사 사회확산 지원 등 }\end{array}$ & 1,400 \\
\hline & & 지역문화 활동가 지원 & $\begin{array}{l}\text { 지역문화활동가 문화프로그램 } \\
\text { 지원 }\end{array}$ & 300 \\
\hline & & ○실버문화페스티벌 지원 & 행사지원 & 1,060 \\
\hline & & O지방문화원 원천콘텐츠 발굴 & $\begin{array}{l}\text { 지역문화콘텐츠개발사업, 지 } \\
\text { 방문화원 소장자료 디지털화 }\end{array}$ & 5,693 \\
\hline & & 이지털 생활사 아카이빙 사업 & $\begin{array}{l}\text { 생활사기록가 모집 및 양성, } \\
\text { 구술 및 채록활동 지원 }\end{array}$ & 900 \\
\hline & $\begin{array}{c}\text { 어르신 } \\
\text { 문화프로그램 운영 }\end{array}$ & 어르신 문화프로그램 운영 & $\begin{array}{l}\text { 문화시설에 고령층 맞춤형 } \\
\text { 문화프로그램 지원 }\end{array}$ & 2,529 \\
\hline
\end{tabular}

지방자치단체는 지역의 문화수요 특성과 인구구성, 문화인프라 특성 등 지역 실정에 맞게 지역 문화향유 프로그램을 추진하고, 문화여가생활 만족도, 삶의 질 개선도 등의 성과지표를 적용할 수 있다. 현재는 분야와 대상을 특정하여 도서관, 생활문화센터, 박 물관·미술관 등 지역의 문화기반시설을 거점으로 활용하여 문화 프로그램(강연, 교육, 행사 등)을 제공하는 방식인데 지역별 인구구성과 생활환경에 맞춰 프로그램을 추진하는 것이 보다 효율적일 것이다. 각 지역은 지역 내 문화재단 등과 연계하여 지역문화 서비 스 제공계획을 지방자치단체 독자적으로 수립할 수 있고, 문체부는 지역문화서비스 통합 관리로(서비스 제공자 등록기준 관리 등) 서비스 품질관리와 함께 지역별 인구, 면적, 경제수준 등에 가중치를 들어 서비스 대상자 수를 기준으로 예산을 산정할 수 있다.

〈표 4-27〉 지역 문화서비스 지원 분야 포괄보조사업 적격성 검토

\begin{tabular}{l|c|c|c|c}
\hline \multicolumn{1}{c|}{ 구분 } & 소액·유사성 & 지역성 & 성과지표 적용 & 예산배정 기준 \\
\hline ㅇㅣㅣㄹ위의 인문학 & $\bigcirc$ & $\bigcirc$ & $\bigcirc$ & $\bigcirc$ \\
\hline 아회문화예술교육 지원 & $\triangle$ & $\bigcirc$ & $\bigcirc$ & $\bigcirc$ \\
\hline 앵ㅎ화문화 활성화 & $\bigcirc$ & $\bigcirc$ & $\bigcirc$ & $\bigcirc$ \\
\hline ㅇㅣㅣㄹ버문화페스티벌 지원 & $\bigcirc$ & $\bigcirc$ & $\triangle$ & $\triangle$ \\
\hline ㅇㅓㅓ르신 문화프로그램 운영 & $\bigcirc$ & $\bigcirc$ & $\bigcirc$ & $\bigcirc$ \\
\hline
\end{tabular}

주: () 매우높음, $\bigcirc$ 높음, $\triangle$ 보통, $\times$ 없음 


\section{제3절 지역문화 성과협약형 포괄보조 기반 조사}

\section{1. 조사개요}

\section{가. 분석대상 및 방법}

지역문화 성과협약형 포괄보조에 대한 지방자치단체 공무원의 인식조사를 실시하여 현장의 실질적 의견을 확인하고 실태를 정리하고자 한다. 조사대상은 전국 243 개 광역 및 기초 지방자치단체의 문화정책 업무담당 공무원이다. 조사방법은 구조화된 설문지를 이용하여 온라인(모바일 병행) 및 이메일 조사로 진행되었다. 조사기간은 2021년 7월 28일 8월 10일으로 약 2주에 걸쳐 실시되었으며, 총 응답자 수는 316명(광역 31명, 기초 285 명)이다.

〈표 4-28〉 조사 개요

\begin{tabular}{c|l}
\hline 구분 & \multicolumn{1}{|c}{ 내용 } \\
\hline 조사대상 & 전국 243개 지방자치단체 공무원 \\
\hline 표본크기 & 총 316명(광역 31명, 기초 285명) \\
\hline 조사기간 & 2021년 7월 28일 8월 10일 (약 2주) \\
\hline 조사방법 & 구조화된 설문지를 이용하여 온라인(모바일 병행), 이메일 병행 \\
\hline
\end{tabular}

조사문항은 포괄보조 방식으로 재정을 지원하고 있는 문화도시사업에 대한 기획 및 정 책과정에서의 인식, 정부 간 관계에 있어서 사업재량과 책임, 성과협약형 포괄보조에 대한 인식을 중심으로 조사하였다. 지방자치단체 현장의 실질적 의견을 확인하기 위해 문화정 책에서 포괄보조 방식으로 재정을 지원하고 있는 문화도시사업 관련 지방자치단체 공무원 을 대상으로 인터뷰를 실시하고, 인터뷰 결과를 기반으로 설문문항을 설계하였다.

2020년 8월 정보람(2020)의 연구에서 전국 지방자치단체 공무원을 대상으로 중앙지방 정부 간 사무배분, 보조사업과 지방자치단체 재정여건에 대한 쟁점 등 포괄보조금 
제도 운영과 관련된 실태와 문제점에 관한 광범위한 조사를 실시한 바 있다. 본 연구에 서는 실제 운영되고 있는 포괄보조형 사업으로 지방자치단체에서 나타나고 있는 변화와 문제점을 심층 분석하고자 문화도시사업을 특정하여 사업기획 및 정책과정을 조사하였 다. 즉 현행 포괄보조형 방식 사업의 사례인 문화도시 조성사업의 기획 및 정책과정, 사 업재량과 책임에 대한 분석을 기초로 하여 지역문화 포괄보조형 사업운영 상의 시사점 을 도출하고자 한다.

〈표 4-29〉조사 문항

\begin{tabular}{|c|c|c|}
\hline \multicolumn{2}{|r|}{ 구분 } & 조사 내용 \\
\hline \multirow{3}{*}{$\begin{array}{c}\text { 사업기획 및 } \\
\text { 정책 과정 }\end{array}$} & 기획 & $\begin{array}{l}\text { - 사업추진을 진행하기까지 의사결정 주체 } \\
\text { - 문화사업 관련 조직 및 인력의 기획역량 정도 } \\
\text { - 문화도시조성사업에서 지역주민 참여 정도와 의사결정 영향 } \\
\text { - 사업 수행 조직구성 및 대응 체계 }\end{array}$ \\
\hline & 집행 & $\begin{array}{l}\text { - 사업의 재원 교부 절차 및 불용액(예산이월) 관리 적절성* } \\
\text { - 사업 집행과정에서 중앙정부의 관리 감독의 적절성* } \\
\text { - 보조금 지불 정산, 사업 보고 등 행정 및 재정관리 효율성* }\end{array}$ \\
\hline & $\begin{array}{c}\text { 사업평가 및 } \\
\text { 성과관리 }\end{array}$ & $\begin{array}{l}\text { - 사업별 성과지표의 변화 방향성 } \\
\text { - 사업의 성과 책임의 귀속 주체 } \\
\text { - 사업에 대한 중앙정부의 성과평가제도의 적절성* }\end{array}$ \\
\hline \multirow{2}{*}{$\begin{array}{l}\text { 정부 간 } \\
\text { 관계 }\end{array}$} & 사업재량과 책임 & $\begin{array}{l}\text { - 중앙정부의 상위계획과 지자체 정책의 일치성 } \\
\text { - 지자체 사업계획의 지역 적합성 정도 } \\
\text { - 지자체 문화정책 집중 분야 } \\
\text { - 지역 기반 문화정책 중 지자체 계획/관리 분야 }\end{array}$ \\
\hline & $\begin{array}{c}\text { 성과협약형 } \\
\text { 포괄보조 } \\
\text { 대안에 대한 인식 }\end{array}$ & $\begin{array}{l}\text { - 지역문화사업의 연계·통합 추진을 위한 중요 요소 } \\
\text { - 포괄보조형 사업이 지자체에 주는 어려움 } \\
\text { - 포괄보조형 사업의 지자체 사업추진 기여도 } \\
\text { - 사업 운영에서의 정부 간 관계 대한 자유 의견 개진 등 }\end{array}$ \\
\hline \multicolumn{2}{|c|}{ 기본 정보 } & $\begin{array}{l}\text { - 소속지자체 } \\
\text { - 문화도시 여부 } \\
\text { - 성별 및 직급 } \\
\text { - 연령 및 근무연수 }\end{array}$ \\
\hline
\end{tabular}

주: *표시는 문화도시 예비도시 진행 또는 본도시 지정된 지자체에 한정하여 응답

\section{나. 응답자의 특성}

각 설문문항에 대한 기초통계분석을 실시하였고, 5점척도로 조사된 문항의 응답처리 는 중간값 3 점을 중립으로하고 1,2 점의 합을 부족, 부적절, 비효율적으로 4,5점의 합을 충분, 적절, 효율적으로 해석하였다. 
설문 응답자들의 인구통계학적 특성을 살펴보면 〈표 4-30〉과 같다. 광역자치단체 31 개, 기초자치단체 285 개가 응답에 참여하였고, 응답자 직급은 지방자치단체는 5급 9급 다양하게 응답하였지만 7급 응답이 35.8\%로 가장 많았다. 근속년수는 공무원 근속년수 3 년 미만 및 현재업무 근속년수 1 년 미만이 가장 높지만, 공무원 근속년수 10 년이상 및 현재업무 근속년수 3년 이상으로 경험이 누적된 응답자도 약 $15 \%$ 수준으로 비교적 고 르게 분포하고 있었다. 문화도시사업 관련하여서는 예비도시 준비에서 본도시 지정까지 문화도시 사업에 관여되어 있는 지방자치단체가 $62 \%$, 문화도시사업과 관련없는 지방자 치단체가 $38 \%$ 로 분포되어 있다. 남성과 여성 성비는 비교적 균등하게 분포하고 있으며, 연령대는 30대와 40대의 응답률이 가장 높았다.

〈표 4-30〉 응답자의 특성

\begin{tabular}{|c|c|c|c|}
\hline \multicolumn{2}{|c|}{ 구분 } & 사례수(명) & 비율(\%) \\
\hline \multicolumn{2}{|c|}{ 전체 } & 316 & 100.0 \\
\hline \multirow{2}{*}{ 자치단체 유형 } & 광역자치단체 & 31 & 9.8 \\
\hline & 기초자치단체 & 285 & 90.2 \\
\hline \multirow{5}{*}{ 직급 } & 5급 이상 & 16 & 5.1 \\
\hline & 6급 & 63 & 19.9 \\
\hline & 7급 & 113 & 35.8 \\
\hline & 8급 & 63 & 19.9 \\
\hline & 9급 & 61 & 19.3 \\
\hline \multirow{4}{*}{ 공무원 근속연수 } & 3년 미만 & 94 & 29.7 \\
\hline & 3년 이상 6년 미만 & 57 & 18.0 \\
\hline & 6년 이상 10년 미만 & 29 & 9.2 \\
\hline & 10년 이상 15년 미만 & 43 & 13.6 \\
\hline \multirow{4}{*}{ 현재업무 근속년수 } & 1년 미만 & 148 & 46.8 \\
\hline & 2년 이상 2년 미만 & 76 & 24.1 \\
\hline & 2년 이상 3년 미만 & 44 & 13.9 \\
\hline & 3년 이상 & 48 & 15.2 \\
\hline \multirow{4}{*}{ 문화도시 여부 } & 예비사업 진행 & 36 & 11.4 \\
\hline & 본도시 지정 & 36 & 11.4 \\
\hline & 예비사업 등 추진 예정 & 124 & 39.2 \\
\hline & 해당사항 없음 & 120 & 38.0 \\
\hline \multirow{2}{*}{ 성별 } & 남성 & 127 & 40.2 \\
\hline & 여성 & 189 & 59.8 \\
\hline \multirow{4}{*}{ 연령별 } & 20대 & 67 & 21.2 \\
\hline & 30대 & 112 & 35.4 \\
\hline & 40대 & 89 & 28.2 \\
\hline & 50대 이상 & 48 & 15.2 \\
\hline
\end{tabular}




\section{2. 분석결과}

\section{가. 문화도시조성사업의 사업기획 및 정책 과정}

1) 사업추진을 결정, 실행하는데 가장 영향력 있는 주체

문화도시조성사업 추진 결정, 실행하는 데 가장 영향력 있는 주체는 44.9\%가 '지방자 치단체장의 의지'로 높게 나타났고, 이외에 '전문가, 주민 등 의견 반영' $28.5 \%$, '지역 내 조직/단체 주도' $14.6 \%$, '지방자치단체 부서(과, 팀 등)의 관심' $12 \%$ 순으로 나타났다.

[그림 4-6] 사업추진을 결정, 실행하는데 가장 영향력 있는 주체

$(\mathrm{N}=316$, 단위: \%)

\begin{tabular}{|r|r|}
\hline 문화도시조성사업추진을 결정·실행하는 데 가장 영향력 있는 주체는 어디입니까? \\
\hline 지자체장 의지에 따라 결정·추진 & 44.9 \\
전문가. 주민 등 의견을 반영하여 결정·추진 & 28.5 \\
지역 내 조직/단체 주도에 따라 결정·추진 & 14.6 \\
지자체 부서(과. 팀 등) 관심으로 결정·추진 & 12 \\
\hline
\end{tabular}

\section{2) 지역 내 문화사업 관련 조직 및 인력의 기획역량 정도}

지역 내 문화사업 관련 조직 및 인력의 기획역량에 대해서는 문화도시 추진 예정 혹은 추진 중인 지방자치단체는 충분하다는 응답이 높은 반면, 문화도시 사업과 관련 없는 지방 자치단체에서는 '부족하다’는 응답(46.7\%)이 상대적으로 높게 나타났다. 구체적으로 지역 내 문화사업 관련 조직 및 인력의 기획역량 정도가 ‘충분하다'는 응답은 예비사업 진행 지 방자치단체 $50 \%$, 본도시 지정 지방자치단체 $38.9 \%$, 추진예정 지방자치단체 $34.7 \%$ 이다.

〈표 4-31〉 지역 내 문화사업 관련 조직 및 인력의 기획역량 정도

\begin{tabular}{|c|c|c|c|c|c|}
\hline \multicolumn{2}{|c|}{ 구분 } & 사례수 & $\begin{array}{l}\text { (1)+(2) } \\
\text { 부족 }\end{array}$ & $\begin{array}{l}\text { (4)+(5) } \\
\text { 충분 }\end{array}$ & $\begin{array}{l}\text { (3) } \\
\text { 보통 }\end{array}$ \\
\hline \multicolumn{2}{|c|}{ 전체 } & (316) & 29.7 & 28.2 & 42.1 \\
\hline \multirow{4}{*}{$\begin{array}{c}\text { 문화도시 } \\
\text { 여부 }\end{array}$} & 예비사업 진행 & (36) & 19.4 & 50.0 & 30.6 \\
\hline & 본도시 지정 & (36) & 13.9 & 38.9 & 47.2 \\
\hline & 추진 예정 & (124) & 21.0 & 34.7 & 44.4 \\
\hline & 해당사항 없음 & (120) & 46.7 & 11.7 & 41.7 \\
\hline
\end{tabular}




\section{3) 사업 추진 시 지역주민의 참여와 의사결정 영향력 정도}

문화도시조성사업을 추진하는 데 지역주민의 참여와 의사결정 영향력에 대해서는 문 화도시 추진 예정 혹은 추진 중인 지방자치단체는 충분하다는 응답이 높은 반면, 문화도 시 사업과 관련 없는 지방자치단체에서는 '부족하다’는 응답(34.2\%)이 상대적으로 높게 나타났다. 구체적으로 지역주민의 참여와 의사결정 영향력 정도가 '충분하다'는 응답은 예비사업 진행 지방자치단체 $58.3 \%$, 본도시 지정 지방자치단체 $38.9 \%$, 추진예정 지방 자치단체 $46 \%$ 이다.

〈표 4-32〉 사업 추진 시 지역주민의 참여와 의사결정 영향력 정도

\begin{tabular}{|c|c|c|c|c|c|}
\hline \multicolumn{2}{|c|}{ 구분 } & 사례수 & $\begin{array}{l}\text { (1)+(2) } \\
\text { 부족 }\end{array}$ & $\begin{array}{l}\text { (4)+(5) } \\
\text { 충분 }\end{array}$ & $\begin{array}{l}\text { (3) } \\
\text { 보통 }\end{array}$ \\
\hline \multicolumn{2}{|c|}{ 전체 } & (316) & 23.1 & 36.7 & 55.0 \\
\hline \multirow{4}{*}{$\begin{array}{c}\text { 문화도시 } \\
\text { 여부 }\end{array}$} & 예비사업 진행 & (36) & 13.9 & 58.3 & 63.2 \\
\hline & 본도시 지정 & (36) & 19.4 & 38.9 & 55.6 \\
\hline & 추진 예정 & (124) & 16.1 & 46.0 & 60.5 \\
\hline & 해당사항 없음 & (120) & 34.2 & 20.0 & 46.7 \\
\hline
\end{tabular}

\section{4) 사업수행을 위한 조직구성 및 대응 체계}

문화도시조성사업을 수행하기 위한 조직구성 및 대응 체계에 대해서는 55.4\%가 '지 방자치단체 행정부서와 민간전담조직이 공동 대응'로 높게 나타났고, 이외에 '전문가 컨 설팅을 참고하여 지방자치단체 행정부서 대응' $34.5 \%$, '민간 사업전담조직을 구성하여 총괄운영' $5.4 \%$ 순으로 나타났다.

[그림 4-7] 사업수행을 위한 조직구성 및 대응 체계

( $\mathrm{N}=316$, 단위: \%)

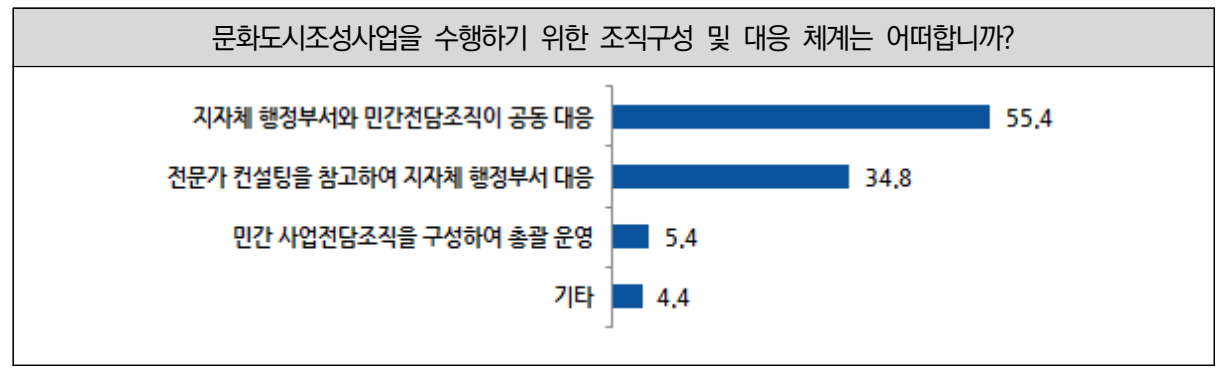




\section{나. 문화도시조성사업의 사업집행 과정}

\section{1) 재원교부 절차 및 불용액 관리 방식 적절 수준}

문화도시 사업의 재원교부 절차 및 불용액(예산이월) 관리 방식에 대해서는 보통이 $59.7 \%$ 인 가운데 적절하다(27.8\%)는 응답이 부적절하다(12.5\%)는 응답보다 약간 높게 나타났다. 재원교부 절차 및 불용액 관리방식 관련하여서는 명확한 경향성을 띈 입장을 나타내는 것이 아니며, 정확한 의사나 판단이 부족한 것으로 보는 것이 타당하다.

〈표 4-33〉 재원교부 절차 및 불용액 관리 방식 적절수준

\begin{tabular}{|c|c|c|c|c|c|}
\hline \multicolumn{2}{|c|}{ 구분 } & 사례수 & $\begin{array}{l}\text { (1)+(2) } \\
\text { 부적절 }\end{array}$ & $\begin{array}{l}\text { (4)+(5) } \\
\text { 적절 }\end{array}$ & $\begin{array}{c}\text { (3) } \\
\text { 보통 }\end{array}$ \\
\hline \multicolumn{2}{|c|}{ 전체 } & (72) & 12.5 & 27.8 & 59.7 \\
\hline \multirow{2}{*}{$\begin{array}{c}\text { 문화도시 } \\
\text { 여부 }\end{array}$} & 예비사업 진행 & (36) & 11.1 & 33.3 & 55.6 \\
\hline & 본도시 지정 & (36) & 13.9 & 22.2 & 63.9 \\
\hline
\end{tabular}

\section{2) 집행과정의 중앙정부 관리감독 적절수준과 행정 및 재정관리 효율 정도}

문화도시사업 집행과정에서 중앙정부의 관리 감독사업에 대해서는 보통이 $58.3 \%$ 인 가운데 적절하다(31.9\%)는 응답이 부적절하다(9.7\%)는 응답보다 높게 나타났다. 그리고 보조금 지불 정산, 사업 보고 등 행정 및 재정관리 효율성에 대해서는 보통이 $52.8 \%$ 인 가운데 효율적이다(30.6\%)는 응답이 비효율적(16.7\%)이라는 응답보다 높게 나타났다.

〈표 4-34〉 집행과정에서 중앙정부의 관리 감독 수준

\begin{tabular}{|c|c|c|c|c|c|}
\hline \multicolumn{2}{|c|}{ 구분 } & 사례수 & $\begin{array}{l}\text { (1)+2 } \\
\text { 부적절 }\end{array}$ & $\begin{array}{l}\text { (4)+(5) } \\
\text { 적절 }\end{array}$ & $\begin{array}{l}\text { (3) } \\
\text { 보통 }\end{array}$ \\
\hline \multicolumn{2}{|c|}{ 전체 } & (72) & 9.7 & 31.9 & 58.3 \\
\hline \multirow{2}{*}{$\begin{array}{c}\text { 문화도시 } \\
\text { 여부 }\end{array}$} & 예비사업 진행 & (36) & 11.1 & 36.1 & 52.8 \\
\hline & 본도시 지정 & (36) & 8.3 & 27.8 & 63.9 \\
\hline
\end{tabular}

〈표 4-35〉 보조금 지불 정산, 사업 보고 등 행정 및 재정관리 효율 정도

\begin{tabular}{cl|c|c|c|c}
\hline \multicolumn{2}{c|}{ 구분 } & 사례수 & $\begin{array}{c}\text { (1)+(2) } \\
\text { 비효율적 }\end{array}$ & $\begin{array}{c}\text { (4)+(5) } \\
\text { 효율적 }\end{array}$ & $\begin{array}{c}\text { 3 } \\
\text { 보통 }\end{array}$ \\
\hline & 전체 & $(72)$ & 16.7 & 30.6 & 52.8 \\
\hline \multirow{2}{*}{$\begin{array}{c}\text { 문화도시 } \\
\text { 여부 }\end{array}$} & 예비사업 진행 & $(36)$ & 16.7 & 30.6 & 52.8 \\
\cline { 2 - 6 } & 본도시 지정 & $(36)$ & 16.7 & 30.6 & 52.8 \\
\hline
\end{tabular}




\section{다. 문화도시조성사업의 평가 및 성과관리}

\section{1) 문화도시조성사업으로 변화된 방향성}

문화도시조성사업으로 변화된 방향성에 대해 '사업계획 및 추진 재량 확대' (81.6\%), '전문가 및 주민의 참여 기회 확대'(81.3\%), '지방자치단체 예산편성 및 집행 탄력성 확 대'(75.6\%), '지방자치단체 수요가 반영된 사업 추진 확대'(72.5\%) 등이 긍정 평가를 나 타내었다. 다만 '유사, 중복성 사업의 통합, 재정 효율화' 측면에서는 확대/강화 의견이 $54.1 \%$ 로 감소/약화 의견 $45.9 \%$ 보다 높지만 차이가 크지 않았다.

[그림 4-8] 문화도시조성사업으로 변화된 방향성

$(\mathrm{N}=316$, 단위: \%)

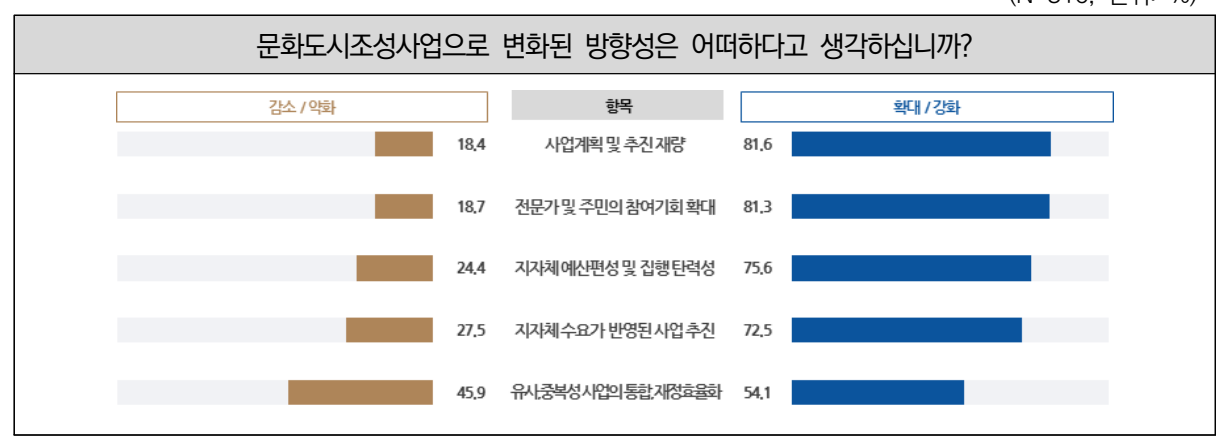

\section{2) 문화도시조성사업 성과 책임 귀속 주체}

문화도시조성사업에 대한 성과 책임 귀속 주체에 대해서는 '지방자치단체'가 중요하 다는 의견이 $51.6 \%$ 로 '중앙정부'가 중요하다는 의견(17.7\%)보다 높게 나타났고, '동등' 해야 한다는 의견은 $30.7 \%$ 로 확인되었다.

[그림 4-9] 문화도시조성사업 성과 책임 귀속 주체

$(\mathrm{N}=316$, 단위: \%)

문화도시조성사업에 대한 성과 책임 귀속 주체는 어디라고 생각하십니까? (상대적으로 중요도)

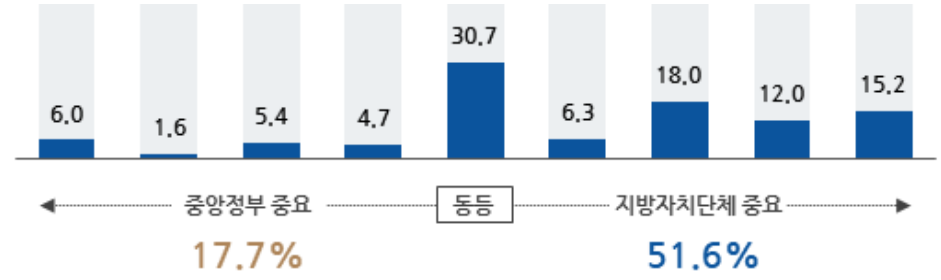




\section{3) 중앙정부의 성과평가제도의 적절 수준}

문화도시조성사업에 대한 중앙정부 성과평가제도에 대해 '보통’이라는 의견이 $69.4 \%$ 인 가운데, '부적절'(19.4\%) 의견이 로 '적절'(11.1\%) 의견보다 약간 높게 나타났다. 명 확한 경향성을 띈 입장을 나타내는 것이 아니며, 정확한 의사나 판단이 부족한 것으로 보는 것이 타당하다.

중앙정부 성과평가제도에 대해 적절하지 않다는 이유로(개방형) 평가기준의 불합리성 과 불명확성에 관련한 의견이 많았다. 구체적으로 사업별 특성과 상황이 반영되지 않은 평가기준이 부적절하다는 의견이 많았고, 평가기준이 명확하지 않다는 의견, 평가 매뉴 얼 부족과 평가대응 행정력 부족 등의 의견이 개방형으로 제시되었다.

〈표 4-36〉 중앙정부의 성과평가제도의 적절 수준

\begin{tabular}{|c|c|c|c|c|c|}
\hline \multicolumn{2}{|c|}{ 구분 } & 사례수 & $\begin{array}{l}\text { (1)+(2) } \\
\text { 부적절 }\end{array}$ & $\begin{array}{l}\text { (4)+(5) } \\
\text { 적절 }\end{array}$ & $\begin{array}{c}\text { (3) } \\
\text { 보통 }\end{array}$ \\
\hline \multicolumn{2}{|c|}{ 전체 } & (72) & 19.4 & 11.1 & 69.4 \\
\hline \multirow{2}{*}{$\begin{array}{c}\text { 문화도시 } \\
\text { 여부 }\end{array}$} & 예비사업 진행 & (36) & 19.4 & 13.9 & 66.7 \\
\hline & 본도시 지정 & (36) & 19.4 & 8.3 & 72.2 \\
\hline
\end{tabular}

\section{라. 문화도시조성사업의 재량 및 재정 분권}

1) 중앙정부의 계획과 지방자치단체 정책의 일치 정도

문화도시조성사업에 대한 중앙정부의 계획과 지방자치단체 정책(계획)의 일치 정도에 대해서는 '보통'이라는 평가가 57.0\%인 가운데, '일치한다'(32.9\%)는 응답이 '불일치한 다'(10.1\%)는 응답보다 높게 나타났다.

〈표 4-37〉 중앙정부의 계획과 지자체 정책의 일치 정도

(단위: \%)

\begin{tabular}{c|c|c|c|c|c}
\hline \multicolumn{2}{c|}{ 구분 } & 사례수 & $\begin{array}{c}\text { (1)+(2) } \\
\text { 불일치 }\end{array}$ & $\begin{array}{c}\text { (4)+(5) } \\
\text { 일치 }\end{array}$ & $\begin{array}{c}\text { 3 } \\
\text { 보통 }\end{array}$ \\
\hline \multirow{2}{*}{ 전체 } & $(316)$ & 10.1 & 32.9 & 57.0 \\
\hline \multirow{3}{*}{$\begin{array}{c}\text { 문화도시 } \\
\text { 여부 }\end{array}$} & 예비사업 진행 & $(36)$ & 5.6 & 38.9 & 55.6 \\
\cline { 2 - 6 } & 본도시 지정 & $(36)$ & 5.6 & 41.7 & 52.8 \\
\cline { 2 - 6 } & 추진 예정 & $(124)$ & 4.8 & 40.3 & 54.8 \\
\cline { 2 - 6 } & 해당사항 없음 & $(120)$ & 18.3 & 20.8 & 60.8 \\
\hline
\end{tabular}




\section{2) 지자체 계획과 지역 수요의 일치 정도}

문화도시조성사업을 위한 지방자치단체 계획과 지역 수요의 일치 정도에 대해서는 '보통' 이 50.3\%인 가운데, '일치한다'(41.8\%)는 응답이 '불일치한다'(7.9\%)는 응답보다 크게 높게 나타났다.

〈표 4-38〉 지자체 계획과 지역 수요의 일치 정도

\begin{tabular}{|c|c|c|c|c|c|}
\hline \multicolumn{2}{|c|}{ 구분 } & 사례수 & $\begin{array}{l}\text { (1)+(2) } \\
\text { 불일치 }\end{array}$ & $\begin{array}{l}\text { (4)+(5) } \\
\text { 일치 }\end{array}$ & $\begin{array}{l}\text { (3) } \\
\text { 보통 } \\
\end{array}$ \\
\hline \multicolumn{2}{|c|}{ 전체 } & (316) & 7.9 & 41.8 & 50.3 \\
\hline \multirow{4}{*}{$\begin{array}{c}\text { 문화도시 } \\
\text { 여부 }\end{array}$} & 예비사업 진행 & (36) & 5.6 & 47.2 & 47.2 \\
\hline & 본도시 지정 & (36) & 0.0 & 50.0 & 50.0 \\
\hline & 추진 예정 & (124) & 6.5 & 49.2 & 44.4 \\
\hline & 해당사항 없음 & (120) & 12.5 & 30.0 & 57.5 \\
\hline
\end{tabular}

3) 지자체의 문화정책 집중 분야와 지자체 차원 관리 필요 분야

지방자치단체의 문화정책 집중 분야로는 35.4\%가 '지역문화서비스(생활문화, 동호회 등) 지원' 으로 가장 높았고, '예술인 창작지원 및 복지'(18.7\%), '지역문화 관련 활동 인 력 양성 및 배치'(15.8\%), '문화시설 개보수'(12.7\%), '전통/향토문화 지원'(11.7\%), ‘벤 처기업 및 창업지원'(3.2\%) 등의 순으로 나타났다.

[그림 4-10] 지자체 문화정책 집중 분야

(복수응답, $\mathrm{N}=316$, 단위: \%)

\begin{tabular}{|r|r|}
\hline 귀하의 지자체 문화정책은 어느 분야에 가장 집중되어 있습니까? \\
\hline $\begin{array}{r}\text { 지역문화서비스지원 } \\
\text { 예술인 창작지원 및 복지 }\end{array}$ \\
지역문화관련 활동인력 양성 및 배치 \\
문화시설 개보수 \\
전통/햫토문화 지원 \\
벤처기업 및 창업지원 \\
기타
\end{tabular}

지역 기반 문화정책 중 지방자치단체 차원에서 계획 및 관리해야 하는 분야로는 42.4\%가 '지역문화 관련 활동 인력 양성 및 배치'로 가장 높았고, '지역문화서비스(생활 문화, 동호회 등) 지원'(39.6\%), ‘문화시설 개보수'(30.7\%), '예술인 창작지원 및 복 
지'(29.1\%), ‘전통/향토문화 지원'(25.6\%), ‘벤처기업 및 창업지원'(7.6\%) 등의 순으로 나타났다.

[그림 4-11] 지자체 차원에서 계획 및 관리 필요 분야

(복수응답, $\mathrm{N}=316$, 단위: \%)

지역 기반 문화정책 가운데 지자체 차원에서 계획 및 관리해야 한다고 생각하는 분아는 무엇입니까?

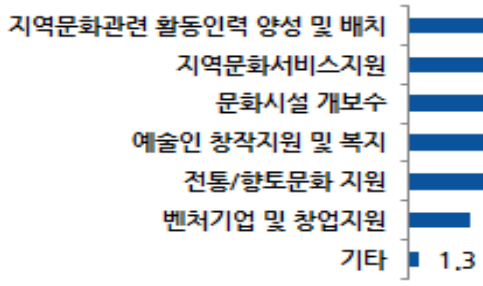

지방자치단체 차원에서 계획 및 관리해야하는 이유(개방형)로 지역에서 보다 체계적 인 관리가 가능하고 지역 현실 반영, 지역 특성에 맞는 계획 수립과 성과도출이 용이한 분야이기 때문이라는 응답이 대부분의 의견이었다.

\section{마. 성과협약형 포괄보조에 대한 인식}

1) 지역문화사업의 연계/통합 추진의 중요 요소

지역문화사업의 연계/통합 추진을 위해 가장 중요한 요소로는 $45.9 \%$ 가 '지역 내 문 화사업 수행 조직의 전문성' 으로 가장 높았고, '지방자치단체의 종합적인 문화사업 계획 수립'(26.9\%), '지방자치단체(장)의 사업 효율화 방침(연계·통합)'(20.6\%), ‘담당공무원 의 역량 $(5.4 \%)$ 등의 순으로 나타났다.

[그림 4-12] 지역문화사업의 연계/통합 추진의 중요 요소

$(\mathrm{N}=316$, 단위: \%)

\begin{tabular}{|r|r|}
\hline 지역문화사업의 연계·통합 추진을 위해 가장 중요한 요소는 무엇이라고 생각하십니까? \\
\hline 지역 내 문화사업 수행 조직의 전문성 \\
지자쳬의 종합적인 문화사업 계획수립 \\
지자체(장)의 사업 쵸율화 방침(연계·통합) \\
담당 공무원의 역량 \\
기타 1.3 \\
5.4
\end{tabular}




\section{2) 포괄보조형 사업시 지자체의 어려움}

포괄보조형 사업 시 지방자치단체의 어려움으로는 $41.5 \%$ 가 '사업 수행 주체 부재 혹은 수행 전문성 부족' 으로 가장 높았고, '전제조건 및 예산용도 제약 등 제한적 재량( $21.8 \%)$, '재원 조달 문제(상위/하위 지방자치단체 협력 부족)'(21.2\%), '제도 및 사업지침에 대한 이해 부족(7\%), '성과지표 발굴 및 설정 어려움'(6.6\%) 등의 순으로 나타났다.

[그림 4-13] 포괄보조형 사업시 지자체의 어려움

$(\mathrm{N}=316$, 단위: \%)

문화도시와 같은 포괄보조형 사업시 지방자치단체의 가장 큰 어려움은 무엇이라고 생각하십니까?

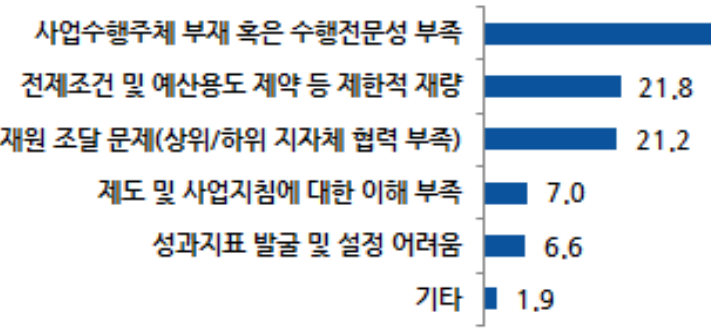

3) 포괄보조형 사업의 지방자치단체 사업추진 자율성, 창의성, 유연성 확보 기여 수준

포괄보조형 사업의 지방자치단체 사업추진 자율성, 창의성, 유연성 확보 기여 수준에 대해서는 보통이 $40.2 \%$ 인 가운데 '기여한다'( $56.3 \%)$ 의견이 '기여하지 않는다'(3.5\%)는 응답보다 보다 크게 높게 나타났다.

포괄보조 사업 운영 관련 개선 의견으로는 '지방자치단체의 자율성 확대', '중앙정부와 지방자치단체 간의 원활한 협력 및 소통', '컨설팅 지원' 등의 의견이 다수 제시되었다.

〈표 4-39〉 포괄보조형 사업의 지자체 사업추진 자율성, 창의성, 유연성 확보 기여 수준

\begin{tabular}{|c|c|c|c|c|c|}
\hline \multicolumn{2}{|c|}{ 구분 } & 사례수 & $\begin{array}{c}\text { (1)+(2) } \\
\text { 기여하지않음 }\end{array}$ & $\begin{array}{l}\text { (4)+(5) } \\
\text { 기여함 }\end{array}$ & $\begin{array}{l}\text { (3) } \\
\text { 보통 }\end{array}$ \\
\hline \multicolumn{2}{|c|}{ 전체 } & (316) & 3.5 & 56.3 & 40.2 \\
\hline \multirow{4}{*}{$\begin{array}{c}\text { 문화도시 } \\
\text { 여부 }\end{array}$} & 예비사업 진행 & (36) & 0.0 & 50.0 & 50.0 \\
\hline & 본도시 지정 & (36) & 0.0 & 55.6 & 44.4 \\
\hline & 추진 예정 & (124) & 1.6 & 63.7 & 34.7 \\
\hline & 해당사항 없음 & (120) & 7.5 & 50.8 & 41.7 \\
\hline
\end{tabular}




\section{3. 시사점}

포괄보조 사업은 특정 서비스 또는 계층에 대해 설계된 사업에 재정이 지원되는 개별 보조금과 달리 넓게 정의된 기능별 목적에 따라 지원되는 재정지원으로, 정책의 조건과 형태에 따라 다양하게 설계된다. 문화분야에서는 '문화도시조성사업'이 지역의 특성과 상황에 맞춰 도시단위의 계획을 수립하고 중앙정보는 계획에 대한 포괄적인 예산을 지 원하는 일종의 포괄보조 사업이다. 지방자치단체 공무원을 대상으로 한 본 설문조사는 응답자의 이해를 돕기위해 현재 문화체육관광부 정책인 문화도시조성사업에 대한 기획, 집행, 성과관리 등과 관련한 현황과 인식을 질의하고, 성과협약형 포괄보조 방식에 대한 인식을 조사하였다. 주요 조사결과와 시사점은 다음과 같다.

(1) 지역 내 기획역량 및 주민 영향력 확보

첫째, 포괄보조형 사업인 문화도시사업을 추진 결정과 실행에 있어서 지방자치단체 장의 의지가(44.9\%) 중요하고, 포괄보조형 사업을 추진하는 지방자치단체는 지역 내 기 획역량과 주민 영향력을 일정수준 확보하고 있는 것으로 확인되었다. 지역 내 문화관련 조직(인력)의 기획역량은 문화도시를 추진하거나 추진 계획인 지방자치단체는 충분하다 고 평가하는 경향을 보이지만(기획역량 충분 의견: 예비도시 $50 \%$, 본도시 $38.9 \%$, 추진 예정 34.7\%), 문화도시 조성과 관계없는 지방자치단체는 역량이 부족하다고(충분 $11.7 \%$, 부족 $46.7 \%)$ 평가하는 경향을 보였다. 이러한 결과는 기획역량이 부족한 지방자 치단체는 문화도시 사업과 같은 포괄보조형 사업에 기회가 박탈되어 점차 지역 간 문화 격차를 악화시킬 수 있다는 점에 유의해야 한다. 문화사업 기획역량이 충분한 지방자치 단체의 사업은 확장되고 반대의 경우는 퇴보할 수 있는 것이다.

또한 지역주민의 참여와 의사결정 영향력 정도에 대해서도 문화도시를 추진하거나 추 진 계획인 지방자치단체는 충분하다고 평가하는 경향을 보이지만(지역주민 영향력 충분 의견: 예비도시 $58.3 \%$, 본도시 $38.9 \%$, 추진예정 $46 \%$ ), 문화도시 조성과 관계없는 지방 자치단체는 주민 영향력이 부족하다고(충분 $20 \%$, 부족 $34.2 \%$ ) 평가하는 경향을 보였다. 그리고 사업을 수행하기 위해서는 지방자치단체 행정부서와 민간이 공동 대응하거나 (55.4\%) 행정부서에서 전문가 컨설팅으로 대응(34.5\%)하고 있었으며, 민간조직 총괄은 (5.4\%) 거의 없었다. 
(2) 지자체 사업계획 및 재정운용 재량 확보

둘째, 포괄보조형 사업인 문화도시 사업은 '사업계획 및 추진 재량 확대'(81.6\%), '전 문가 및 주민의 참여 기회 확대'(81.3\%), '지방자치단체 예산편성 및 집행 탄력성 확 대'(75.6\%), '지방자치단체 수요가 반영된 사업 추진 확대'(72.5\%) 등의 긍정 평가를 나 타내었다. 그리고 포괄보조형 사업이 지방자치단체 사업추진 자율성, 창의성, 유연성 확 보에 대부분의 지방자치단체가 기여한다는 의견을 나타내었다(기여함 $56.3 \%$, 기여하지 않음 3.5\%). 다만 문화도시 사업에 대해 '유사, 중복성 사업의 통합, 재정 효율화' 효과 는 명확한 경향성을 나타내지 않았다(긍정 $54.1 \%$, 부정 $45.9 \%)$.

(3) 중앙정부 계획연계, 지역 수요를 반영한 계획 수립

셋째, 포괄보조형 사업인 문화도시사업은 중앙정부의 계획과 지방자치단체의 계획이 일치하다는(일치 $32.9 \%$, 불일치 $10.1 \%$ ) 의견이 높았고 특히 지방자치단체의 계획은 지 역수요와 일치하다는(일치 $41.8 \%$, 불일치 $7.9 \%$ ) 의견이 크게 높았다. 지방자치단체에서 집중하고 있는 문화정책 분야는 생활문화, 동호회 등 지역문화서비스로 확인되었고, 지 역기반 문화정책 가운데지방자치단체 차원의 계획·관리가 필요한 분야는 지역문화 관련 활동인력 양성·배치, 지역문화서비스 지원이 $40 \%$ 대로 크게 높았다. 이외 문화시설 개보 수, 예술인 창작지원 및 복지, 전통/향토 문화 지원도 25 30\%대로 지방자치단체 차원 에서 계획·관리되어야 하는 분야로 강조되었다.

\section{(4) 수행조직의 전문성 중요}

넷째, 지역문화사업의 연계·통합 추진을 위해 수행조직의 전문성(45.9\%)을 가장 중요 한 요소로 여기고 있었으며, 지방자치단체의 계획수립(26.9\%), 지방자치단체 장의 사업 효율화 방침(20.6\%)도 일부 의견이 있었고 담당공무원의 역량은(5.4\%) 거의 중요하게 여기지 않는 것으로 확인되었다. 그리고 포괄보조사업 추진 애로사항으로 수행주체 부재 및 전문성 부족(41.5\%)이 가장 높게 확인되었고, 이외 제한적 재량권(21.8\%), 상위 지방 자치단체 협조 등 재원조달 문제(21.2\%)에 대한 의견도 확인되었으며, 일부 지침에 대한 이해부족(7\%), 성과지표 발굴·설정 어려움(6.6\%) 의견이 있었다. 
(5) 중앙정부 관리감독은 적절하나 성과관리 보완 필요

다섯째, 문화도시사업의 집행과정과 보조금 지불정산 관련한 중앙정부의 관리감독은 적절하고(적절 31.9\%, 부적절 9.7\%) 효율적이라는(효율적 30.6\%, 비효율적 16.7\%) 의 견이 높지만, 성과관리는 부적절하다는(적절 $11.1 \%$, 부적절 $19.4 \%$ ) 의견이 약간 높게 나타났다20). 부적절하다는 이유로는 사업별 특성과 상황이 반영되지 않은 평가기준, 불 명확한 평가기준, 평가대응 행정력 부족 등의 의견이 개방형으로 확인되었다. 그리고 성 과책임 귀속 주체는 중앙정부보다 지방자치단체가 상대적으로 중요하다고(성과책임 중 요: 중앙 $17.7 \%$, 지방자치단체 $51.6 \%$ ) 판단하고 있었다.

종합하면, 성과협약형 포괄보조사업 추진은 지방자치단체의 사업계획 및 재정운용 재 량을 부여하고 지역 내 수요를 반영하는데 긍정적인 방식으로 평가되고, 지방자치단체 사업추진에 있어서 자율성, 창의성, 유연성 확보에 기여하는 것으로 판단된다. 포괄보조 방식이 지방자치단체의 사업기획 및 조정 능력을 개선하는데 도움이 된 것이다. 다만 포괄보조형 사업 추진을 위해서는 수행조직의 전문성이 핵심요소인 것으로 확인된다. 문 화도시를 추진하는 도시가 그렇지 않은 도시보다 문화관련 조직의 기획역량이 높게 나 타났고, 지역문화사업의 연계·통합 추진에 수행조직의 전문성을 가장 중요한 요소이고 애로사항이 수행주체의 부재로 나타났기 때문이다. 그리고 중앙과 지방자치단체 간의 관 계에 있어서 집행재량은 확보되지만 성과관리체계에 있어 평가기준과 지표, 평가방식 등 의 개선이 필요해 보인다. 마지막으로 포괄보조사업 방식은 지역수요를 반영하는데 긍정 적인 효과를 일으키고 있었고, 지역문화 정책 수요가 높은 분야는 생활문화, 동호회 등 지역문화서비스로 확인되었다. 지역의 문화정책 수요가 높고 지방자치단체 차원의 계 획·관리가 필요한 분야는 생활문화, 동호회 등 지역문화서비스이고 지역문화정책 수요 가 상대적으로 높지 않지만 지방자치단체 차원의 계획·관리가 필요한 분야로 문화인력 양성·배치가 확인되었다.

20) 문화도시 사업에 대한 중앙정부의 관리감독 적절성, 효율성 관련 문항에는 '보통'으로 중립 의견이 50 60\%대로 높게 나타나 명확한 경향성을 띈 의견으로 해석하기는 곤란하지만, 이는 1차 문화도시 지 정이 2020년으로 사업의 초입단계이기 때문으로 판단됨. 따라서 '보통' 의견이 우세함에도 불구하고 적 절과 부적절, 효율적과 비효율적 의견의 차이를 해석하였음 
지역문화 성과협약형 포괄보조 방식 도입방안 연구

제5장

지역문화 성과협약형

포괄보조 방식 도입방안 



\section{제1절 중앙부처의 보조사업 체계}

\section{1. 종합진단}

\section{가. 국가 지역문화정책 비전과 조직의 업무영역}

성과협약형 포괄보조 방식 도입을 위해서는 중앙부처 재정사업의 대상과 범위를 설정 하고, 이것을 이행하는 조직의 업무영역이 연계·포괄되어야 한다. 현재는 국가 단위의 지역문화정책 비전 및 핵심과제와 이것을 소관하는 부서의 업무영역이 상당수준 연계. 포괄되지 못하게 설정되어 있다.

국가 수준의 지역문화 정책은 「지역문화진흥기본계획」이고, 문화정책 중장기 비전인 「문화비전2030, 사람이 있는 문화」, 문화체육관광부 업무계획 및 성과관리계획에 포함 되어 있다. 2018년 5월 발표된 문화정책의 중장기 비전인 「문화비전2030, 사람이 있는 문화」에서 9대 의제 중 6 번이 '지역문화 분권 실현'이다. 그리고 문화체육관광부 업무계 획의 15 대 과제 중 하나는 '지역문화 진흥 및 균형발전'이고, 부처 성과관리계획의 프로 그램 목표 중 하나는 '지역문화 균형발전 및 생활 속 문화향유 기회 확대'이다. 그리고 「지역문화진흥법」에 근거하여 2020년 발표된「제2차 지역문화진흥 기본계획(2020 2024)」의 비전은 '포용과 혁신의 지역문화'이고 시민의 참여로 문화자치 생태계 구축, 포용과 소통으로 생활기반 문화환경 조성, 지역의 개성 있는 문화 발굴·활용, 문화적 가 치로 지역의 혁신과 발전이라는 4 개의 전략을 담고 있다.

중앙정부의 지역문화정책의 비전은 분권과 균형발전, 생활기반 문화향유로 정리할 수 있고,지역문화정책 목표는 지역 간 격차해소, 지역별 특색있는 고유문화의 발전, 지역 주민 삶의 질 향상을 위한 지역문화정책 추진으로 정리할 수 있다. 이러한 지역문화정책 은 특정사업의 결과가 아닌 지역의 문화시설, 인력, 프로그램이 유기적으로 연계되고 지 역발전 관점에서 체계적인 접근이 필요한 영역이라 할 수 있다. 
〈표 5-1〉 중앙정부의 지역문화정책 비전 및 목표

\begin{tabular}{|c|c|c|c|c|}
\hline 구분 & $\begin{array}{l}\text { 문화비전2030 } \\
\text { (2019.2 발표) }\end{array}$ & $\begin{array}{c}\text { 문체부 업무계획 } \\
\text { (2021년) }\end{array}$ & $\begin{array}{c}\text { 문체부 성과관리계획 } \\
\text { (2021년) }\end{array}$ & $\begin{array}{c}\text { 지역문화진흥기본계획 } \\
\text { (2020 2024) }\end{array}$ \\
\hline $\begin{array}{l}\text { 계획의 } \\
\text { 구성 }\end{array}$ & $\begin{array}{l}\text { 9대의제 47개 대표 } \\
\text { 과제 }\end{array}$ & 4대 전략 15대 과제 & $\begin{array}{c}\text { 6대목표 22대 } \\
\text { 프로그램(성과목표) }\end{array}$ & 4대 전략 15대 과제 \\
\hline $\begin{array}{l}\text { 지역문화 } \\
\text { 관련 전략 } \\
\text { 및 과제 }\end{array}$ & $\begin{array}{l}\text {-의제6: 지역 문화분 } \\
\text { 권 실현 } \\
\text {-대표과제6-1:지역 } \\
\text { 문화자치를 위한 기 } \\
\text { 반 조성. } \\
\text {-대표과제6-2: 지 } \\
\text { 역 문화의 고유성 } \\
\text { 유지·발전 } \\
\text {-대표과제6-3: 지역문 } \\
\text { 화 거점기관 운영 혁 } \\
\text { 신과 지윤체계 마년 } \\
\text {-대표과제6-4:문화 } \\
\text { 협치를 위한 협력체 } \\
\text { 계 구축 }\end{array}$ & $\begin{array}{l}\text {-전략2: 문화향유 확 } \\
\text { 대 } \\
\text {-과제2-8:지역문화 } \\
\text { 진흥 및 균형발전 }\end{array}$ & $\begin{array}{l}\text {-전략1: 삶의 질을 높 } \\
\text { 이는 국민문화 환경 } \\
\text { 조성 } \\
\text {-프로그램1-2: 지역 } \\
\text { 문화 균형발전 및 생 } \\
\text { 활 속 문화향유 기회 } \\
\text { 확대(생활 속 문화기 } \\
\text { 반 조성) } \\
\text {-관리과제1-2-1: 지 } \\
\text { 역문화 활성화 }\end{array}$ & $\begin{array}{l}\text { (비전: 포용과 혁신의 지 } \\
\text { 역문화) } \\
\text {-전략1: 시민의 참여로 } \\
\text { 문화자치 생태계 구축 } \\
\text {-전략2: 포용과 소통으 } \\
\text { 로 생활기반 문화환경 } \\
\text { 조성 } \\
\text {-전략3: 지역의 개성있 } \\
\text { 는 문화 발굴·활용 } \\
\text {-전략4: 문화적 가치로 } \\
\text { 지역의 혁신과 발전 }\end{array}$ \\
\hline $\begin{array}{l}\text { 지역문화 } \\
\text { 관련 성과 } \\
\quad \text { 지표 }\end{array}$ & - & $\begin{array}{l}\text {-지역규모별 문화향유 } \\
\text { 격차 감소 } \\
\text {-박물관·도서관 등 문 } \\
\text { 화기반시설 증가 }\end{array}$ & $\begin{array}{l}\text {-지역문화전문인력 양 } \\
\text { 성사업 참여자 만족도 } \\
\text {-생활문화동호회 지원 } \\
\text { 사업 참여 동호회 수 }\end{array}$ & $\begin{array}{l}\text {-지자체 문화예술 재정 } \\
\text { 비중 증대 } \\
\text {-지역규모별 문화향유 } \\
\text { 격차 감소 }\end{array}$ \\
\hline
\end{tabular}

그런데 지역문화정책을 소관하는 문화체육관광부의 지역문화정책관 재정사업들은 지 역밀착형 시설 확충, 문화도시 조성, 일상 속 생활문화 지원(동호회, 어르신 등) 등이고 대부분의 예산을 박물관, 도서관, 생활문화센터와 같은 문화시설 건립에 사용하고 있다. 생활기반 문화향유를 위해서는 생활문화서비스와 관련된 업무가 조직(지역문화정책관) 의 핵심영역으로 설정되어야 하는데 현재는 예술정책관 소관이 더 많다.

문화의 달 행사 지원 등 지역에서 문화서비스를 제공하는 지역문화정책과 소관의 사 업은 '지역문화진흥' 3.7억원, '국민문화활동지원' 36억원 수준인 한편 예술정책관 소관 의 생애주기별 문화서비스를 지원하는 '지역문화예술교육 지원' 은 130 억원 수준이고 통 합문화이용권을 지원하는 '문화예술향유지원'은 1,240 억원 규모이다.

이러한 업무영역 구성은 개별 사업의 관리에서 긍정적인 성과가 창출되어도 지역문화 진흥을 목적으로 하는 성과와 직접적 관련성이 취약하기 때문에 포괄보조프로그램이 지 향하는 재량과 책임 그리고 문화분권 혁신을 유도하는데 한계가 있다. 
〈표 5-2〉 문화체육관광부 문화예술정책실 하부 부서별 지자체 국고보조사업(2021년)

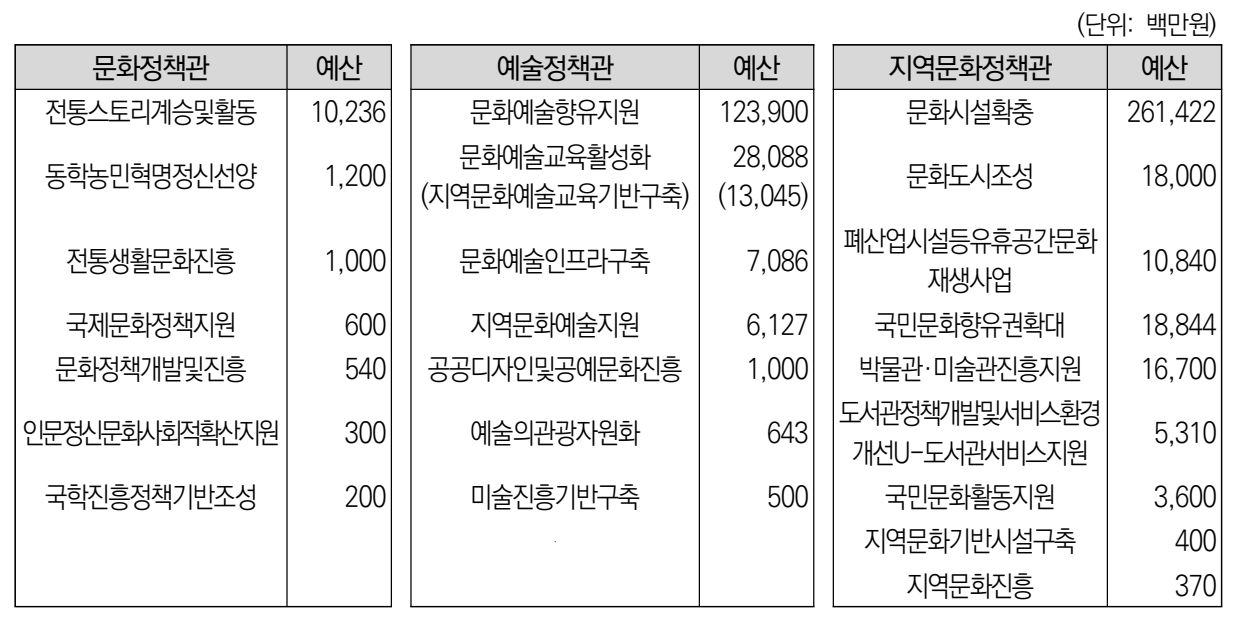

\section{나. 포괄보조 사업전환 방식: 기존 개별사업의 기득권 쟁점}

국고보조사업 가운데 지방정부의 사업관리가 정착된 소규모 영세사업들을 임의적으 로 묶어 하나의 예산단위로 통합지원하면 포괄보조의 혁신성을 확보하기 힘들다. 문화체 육관광부는 최근 2-3년 사이 지역 수준에서 개별 정책 사업들의 통합성을 높이기 위해 일부 개별 보조사업을 통합지원하고 지역 내 수요와 특성을 반영한 계획에 대해 예산을 지원하는 상향식 접근방식을 시도하고 있다.

그런데 개별보조사업을 통합지원하는 방식은 외형적으로는 포괄보조 시스템을 표방 하지만 중앙부처의 사업소관 부서 및 사업운영 방식은 기존의 개별사업 지침을 유지하 고 있어 개별사업과 크게 다를 바 없는 한계가 있다. 통합지원으로 지역 내 협력과 사업 간 연계를 유도하기 위한 취지였으나, 이전 개별사업의 운영지침과 회계를 그대로 유지 하고 있어 지방자치단체 입장에서는 사업기획 및 집행에 여전한 칸막이가 존재하는 것 이다. 특히 집행체계가 다르면 별개의 사업으로 운영되고 있는 것과 다름이 없다. 문화 체육관광부의 보조사업 통합지원 시도뿐만 아니라 본 연구에서 살펴본 복지부의 지역사 회 통합건강증진사업의 경우도 통합지원 이전 개별사업 운영지침을 유지하고 있다보니 지역단위에서 사업 우선순위를 반영한 계획 수립은 불가능한 구조이다.

포괄보조 방식은 개별사업 추진보다 연계·통합할 때 시너지가 있는 영역을 정하고, 관련된 기존 예산을 하나의 예산관리제도 틀 속에 묶어 포괄보조 프로그램으로 개편하 
는 방식을 주로 택하고 있다. 이러한 경우 기존의 개별 사업에 배정되는 재원(예산)의 기득권을 계속 인정할 것인지에 대한 쟁점이 발생한다. 개별사업의 예산기득권은 재정사 업에 이해관계가 형성된 중앙 및 지방단체까지 망라적으로 영향을 받고, 이미 중앙정부 와 지방정부의 사업관리가 정착된 경우 실질적인 통합이 어렵게 된다. 이러한 이유로 현실에서는 개별사업들의 기득권을 계속 인정하게 되는데, 이 경우 포괄보조 혁신효과는 제한적일 수밖에 없다. 오히려 지방자치단체 입장에서는 이전보다 개선되지 않은 좀 더 복잡한 국고보조사업으로 인식하게 되는 것이다.

\section{2. 추진방안}

\section{가. 지역문화 시설, 인력, 서비스 연계: 전담조직화}

성과협약형 포괄보조 방식은 개별보조금(소규모 사업)을 합하는 재정형태 자체의 결 과가 아닌 정부간 재정관계와 역할분담과 성과책임을 명확하게 하여 재정효율화를 기대 하는 정책 수단이다. 프로그램 단위에서 추구하는 성과(결과)가 구체적으로 명시되고 정 부간 성과협약 혹은 성과계약을 통한 성과책임 구조가 설계될 수 있는 수준에서 포괄보 조프로그램의 사업구조를 설계해야 한다. 그리고 재정성과 책임을 강화하기 위해서는 포 괄보조 사업의 재정운영 및 기능 그리고 성과관리를 전담하는 방식으로 재정사업 수행 구조를 개편해야 한다.

포괄보조를 통한 문화분권 활성화를 위해서는 문화예술의 특정 영역에 대해 서비스, 시설, 인력에 대한 통합적 지원체계 형성이 중요하다. 그런데, 현재 문예정책실의 부서 별 재정기능분담들은 조직 차원에서 분리된 상태이다. 지역문화정책관 부서의 소관 재정 사업들은 주로 문화시설투자에 대한 것이다. 시설투자는 프로그램 이용과 유기적으로 결 합되고 상호 교환할 수 있는 선택이 활성화되어야 한다. 특히 이용자 중심의 문화확충 프로그램으로 운영하기 위해서는 관련 재정의 통합관리가 중요하다.

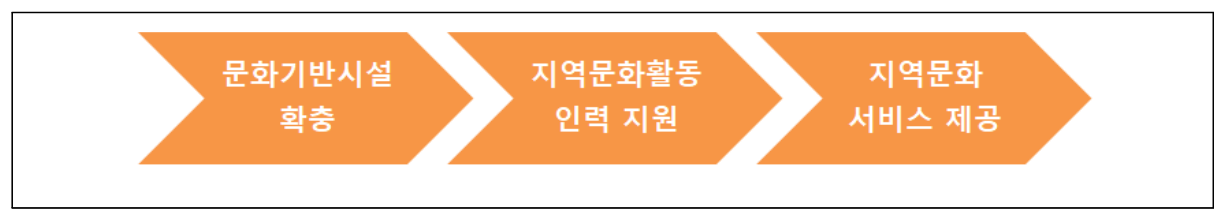


중앙정부와 지방정부간 성과협약체계를 운영할 때, 포괄보조프로그램을 담당하는 총 괄부서를 지정하고 재원배분과 사업관리에서 권한 및 책임에 대한 내용을 명확히 설정 해야 한다. 프로그램 내 개별 사업단위별로 중앙과 지방에서 각각의 소관 부서들간에 사업운영 혹은 사업관리방식을 수직적으로 계열화하면, 현재와 같은 개별 사업단위별 국 고보조방식에서 확인되는 비효율적인 재정 쟁점이 발생한다. 중앙과 지방 모두 하나의 책임 부서가 프로그램을 총괄적으로 책임지는 성과계약 구조를 설계해야 한다. 현재는 지역문화진흥 관련 재정사업을 문화체육관광부 내 여러 부서에서 수행하기 때문에 단일 한 부서에서 성과관리를 총괄하기 힘들다. 따라서 문화분권과 정부간 문화재정관계를 재 설정할 필요성이 인정되는 영역들을 구체적으로 검토하고, 지역문화 진흥 담당 부서(지 역문화정책관)가 성과관리를 책임지는 전략적인 영역 식별이 중요하다.

\section{나. 지역기반 지역문화사업 재구조화}

지역문화진흥은 문화기반시설 확충, 문화서비스 확대, 문화역량 강화에 기본 방향을 두고 있고, 시설과 서비스, 인력이 유기적으로 연결되어야 지역에서 다양한 문화서비스 를 발굴·제공할 수 있다. 현재는 문화인력, 지역문화서비스와 관련된 사업이 파편화되어 있는데, 유사기능별 사업군을 묶어 포괄보조 프로그램으로의 재구조화가 필요하다. 이를 위해서는 생활권 내 소비하는 문화서비스 제공, 문화서비스를 제공 혹은 이용자와 연결 하는 인력의 양성 및 배치와 관련된 세부사업을 하나의 포괄보조 사업으로 설계해야 한 다. 포괄적 보조금(Block Grants)은 특정 사업을 구체적으로 접근하는 것이 아닌, 일반 적이고 광범위한 영역을 대상으로 한다. 예를들어 실버문화페스티벌이나 길위의 인문학 과 같이 구체적인 사업이 아닌 지역문화서비스와 같이 포괄적 사업으로 접근한다.

본 연구의 4장에서는 문화체육관광부 사업에서 지역문화 성과협약형 포괄보조 방식 적격성을 검토하였고, 그 결과 전통생활문화, 지역문화 활동인력, 지역문화서비스 등 3 가지 세부유형의 포괄보조화 방안을 검토하였다.

먼저 전통생활문화는 현재의 '전통생활문화 활성화 지원', '전통놀이문화 조성 및 확 산', ‘세시풍속 맥 잇기', '디지털 생활사 아카이빙 사업'을 하나의 포괄보조 사업으로 한다. 지역의 역사적, 문화적, 생활사적 특성에 따라 중요하게 여기는 가치를 수집, 관리, 활성화, 사업화 측면에서 지방자치단체 자체 계획이 효과적이고, 전통생활문화에 대한 
인식도, 전통생활사 애착도, 전통생활상품 사업화 실적 등을 성과지표로 적용할 수 있다.

지역문화 활동인력은 현재의 ‘이야기할머니 인력양성 및 활동지원’, ‘인생나눔교실 운 영', ‘지역문화예술교육 지원', ‘문화예술교육 전문인력양성', ‘지역문화역량 강화', '지역 문화 활동가 지원'을 하나의 포괄보조 사업으로 한다. 지방자치단체는 지역의 문화수요 특성과 노동시장 실정에 맞게 인력을 교육하고 일자리에 연계하여 배치할 수 있고, 활동 률, 취업률, 재교육률 등의 성과지표를 적용할 수 있다.

지역 문화서비스 지원은 현재의 '길 위의 인문학', '사회문화예술교육 지원', '생활문 화 활성화', '실버문화페스티벌지원', '어르신문화프로그램운영' 을 하나의 포괄보조 사업 으로 한다. 지방자치단체는 지역의 문화수요 특성과 인구구성, 문화인프라 특성 등 지역 실정에 맞게 지역 문화향유 프로그램을 추진하고, 문화여가생활 만족도, 삶의 질 개선도 등의 성과지표를 적용할 수 있다.

〈표 5-3〉지역문화 성과협약형 포괄보조 사업분류(안)

\begin{tabular}{|c|c|c|}
\hline 포괄보조사업명 & 현행 사업명(내역사업) & 검토이유 \\
\hline 전통생활문화 & $\begin{array}{l}\text { 전통생활문화 활성화 지원 } \\
\text { 전통놀이문화 조성 및 확산 } \\
\text { 세시풍속 맥 잇기 } \\
\text { 디지털 생활사 아카이빙 사업 }\end{array}$ & $\begin{array}{l}\text { 지역을 기반으로 한 생활문화인 전통적 관 } \\
\text { 습과 풍속, 향토문화 자원 등을 수집, 관리, } \\
\text { 상품화 및 디지털화하는 것으로 지역의 고 } \\
\text { 유성이 중시되는 영역 }\end{array}$ \\
\hline 지역문화 활동인력 & $\begin{array}{l}\text { 인생나눔교실 운영 } \\
\text { 이야기할머니 인력양성 및 활동지원 } \\
\text { 지역문화예술교육 지원 } \\
\text { 문화예술교육 전문인력 양성 } \\
\text { 지역문화역량 강화 } \\
\text { 지역문화 활동가 지원 }\end{array}$ & $\begin{array}{l}\text { 지역의 문화전문 인력이라는 명확한 대상에 } \\
\text { 초점을 두고 지역 내 일자리 수요·공급이 } \\
\text { 이루어지고 있기 때문에 자치단체 차원에서 } \\
\text { 인적자원 관리가 필요한 영역 }\end{array}$ \\
\hline 지역문화서비스 & $\begin{array}{l}\text { 길위의 인문학 } \\
\text { 사회문화예술교육 지원 } \\
\text { 생활문화 활성화 } \\
\text { 실버문화페스티벌 지원 } \\
\text { 어르신 문화프로그램 운영 }\end{array}$ & $\begin{array}{l}\text { 지역의 인구구성, 생활특성애 따라 주민의 } \\
\text { 문화서비스 선호 및 욕구가 다르기 때문에 } \\
\text { 자치단체 차원에서 지역의 특성을 반영하여 } \\
\text { 세부계획을 세우는 것이 효율적인 영역 }\end{array}$ \\
\hline
\end{tabular}




\section{다. 생활권-도시권-광역권 전략적 접근}

개별사업의 운영 관성과 기득권 쟁점을 고러하면 새로운 지역문화 포괄보조금의 재원 을 확보하고, 지역문화진흥에 대한 구체적인 성과목표가 설정되는 신규 사업방식의 포괄 보조프로그램이 바람직하다. 하지만 국가재정 여건을 고려할 때, 의미있는 수준의 재원 규모를 확보하여 신규 사업을 추진하는 것은 쉽지 않다. 따라서 기존사업 조정방식으로 접근하는 것이 현실적일 수 있으며, 이 경우 지역문화 포괄보조 대상 범위를 생활권, 도 시권, 광역권 등으로 권역적(영토적)으로 전략 접근할 필요가 있다. 지방자치단체의 문화 정책 분야에 사업운용 재량을 부여하는 것부터, 지역문화 활성화라는 결과지향적 성과를 이끌어 내기 위한 체계적 접근이다.

[그림 5-1] 생활권-도시권-광역권 포괄보조 전략적 접근 방안

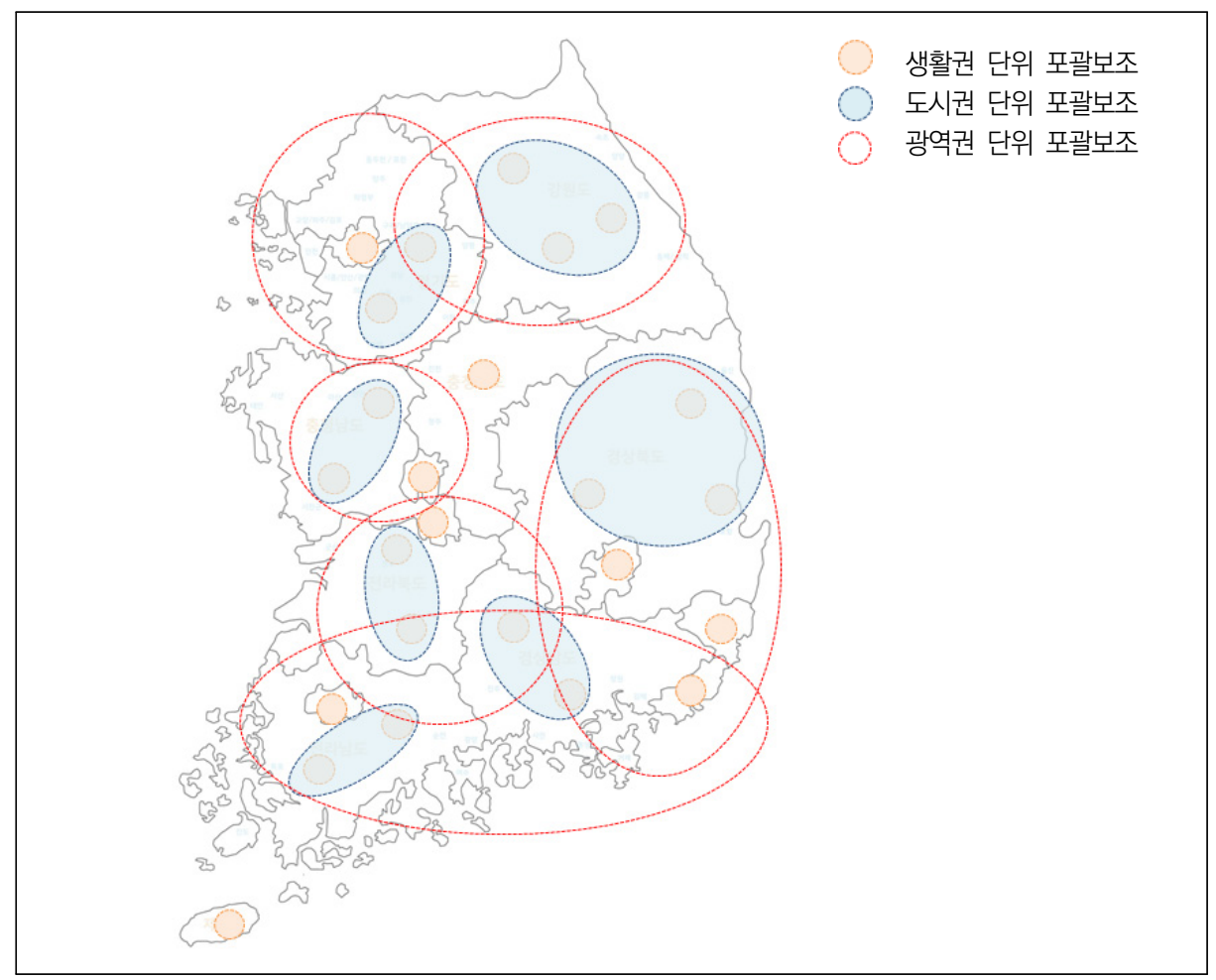




\section{1) 생활권 단위 포괄보조}

생활권 단위 포괄보조는 지역주민의 생활반경 내 커뮤니티 계획으로 지역 내 인프라인력-서비스를 연계하는 계획에 대한 포괄보조를 의미한다. 지역문화 관련 인프라, 인 력, 서비스와 관련 중앙정부 사업목록을 메뉴화하여 지역 상황에 맞추어서 자율적으로 커뮤니티 계획을 수립하도록 유연성을 부여하는 것이다.

이는 시범사업으로 시도된 '지역문화 생태계 구축 통합운영' 사업과 '생활문화사업 통 합지원' 사업을 보완하여 추진 가능하다. 해당 사업은 지역문화진흥원에서 운영을 전담 하고 있는데, 사업목록 및 운영방식을 일부 수정하여 접근할 것을 제안한다. 현재는 외 형적으로는 포괄보조 시스템을 표방하지만 기존 개별사업 지침을 여전히 적용하고 있기 때문에 지역 내 계획과 우선순위를 설계할 재량은 제한적이다. 때문에 지역에서는 개별 사업과 다를 바 없으면서 복잡한 보조사업 형태로 인식되는 것이다.

이를 개선하면서 생활권 단위 포괄보조로 조정하기 위해서는 인프라, 인력, 서비스와 관련된 중앙정부 사업을 내역사업 단위에서 목록화하여 지역 내 계획수립 사업메뉴로 활용하도록 하고, 공통적으로 적용해야 하는 사업을 필수로 포함하는 방식이 적절하다. 우선 문화체육관광부 지역문화정책관 사업에 한정하여 사업메뉴를 제공하고 지역에서 계획을 수립하도록 하고, 점차 문화정책관 및 예술정책관 등 중앙정부 타부서 계획도 연계하는 것이 현실적이다.

그리고 포괄보조 사업은 지방자치단체에게 기존의 개별보조사업 방식과는 완전히 다 른 역할 및 업무가 부여되기 때문에 시범사업을 통한 점검과 분석, 제도의 조정이 필요 한데, 시범사업 대상을 공모로 결정하기보다 기획역량이 상대적으로 우수한 지방자치단 체를 중앙정부가 임의적으로 결정하는 방식이 적합할 수 있다. 포괄보조 범위와 주체간 역할분담이 명확하게 결정되지 않은 상태에서 연계계획에 대한 재정재량 부여는 사업수 행자로 하여금 지역문제 해결보다는 보조금 유치에 관심이 집중될 수 있기 때문이다. 따라서 기획역량이 상대적으로 높게 형성되어 있는 지방자치단체에 우선 실시한 다음 확대여부를 결정하는 점진적 접근이 필요하다. 특광역시의 경우는 시본청에서 직접 수행 하는 사업들이 많고 자치구에 대한 재정조정기능이 활성화되어 있는 한편, 광역도는 전 반적으로 재정이 취약하고 군의 면적이 넓기 때문에 재정조정 기능이 약화되어 있다. 특광역시의 시본청이나 광역도 하부의 기획역량이 확보된 기초자치단체를 우선 적용해 
보는 방식을 고려할 수 있을 것이다. 시범운영 기간동안 성과협약형 포괄보조 방식이 기존의 개별 보조방식보다 효율성, 효과성이 충분한지와 같은 제도 자체에 대해 진단하 고, 제도 설계와 운영 상의 한계와 개선점 등이 분석되어야 한다.

더불어 적극적인 지역의 참여와 실효성있는 계획수립을 유도하기 위해 생활권 단위 포괄보조 방식 이행지역을 '문화도시조성' 사업 참여에 가점을 주도록 제도 간 연계하는 방식의 검토도 필요하다. 그리고 공통적으로 적용해야 하는 사업은 국가단위 지역문화 계획인 '지역문화진흥 기본계획'과 연계하여 설정하고, 지방이양 사업을 연계하여 기획 하도록 하는 것이 효과적일 것이다.

\section{2) 도시권 단위 포괄보조}

도시권 단위 포괄보조는 도시 고유의 문화적 정체성과 브랜드를 형성하는 전략에 대 한 포괄보조를 의미한다. 도시의 문화적 자원(역사전통, 예술, 문화산업, 사회문화 등) 분석을 기초로하여 도시권 문화브랜드 계획을 수립하는 것이다. 이는 현행 법정계획인 '문화도시 조성'사업을 보완하여 추진 가능하다. 현재 문화도시조성사업은 기본적으로 문화예술·문화산업·관광·전통·역사·영상 등 특색있는 지역문화 자원으로 지역발전 측면 의 거시적 시각에서 도시를 선정하는 취지이나, 실제 재정이 열악한 기초자치단체의 포 괄예산 확보에 과열된 경향을 보이고 있다. 기초자치단체를 중심으로 문화도시 선정이 진행되다 보니 도시권 단위의 문화브랜드 형성보다 생활권 단위의 주민욕구 중심 프로 그램으로 계획이 구성되어 있다.

이를 개선하면서 도시권 단위 포괄보조로 조정하기 위해서는 문화도시 조성사업을 생 활권 단위 포괄보조 사업과 분리하고, 연동하여 단계적으로 성장할 수 있는 틀을 마련할 필요가 있다. 주민 삶의 질, 주민의 욕구와 수요가 반영된 프로그램은 생활권 포괄보조 에서 추진하고, 문화도시조성사업 계획에서는 문화도시로서 특색있는 “전략”을 수립하 도록 접근관점을 체계화 하는 것이다. 문화도시 전략을 수립한다는 것은 사업효율화 보 다 지역 내 기획 및 운영역량이 중요한데, 중앙정부의 지역문화정책을 전담하는 지역문 화정책관은 계획수립 역량강화를 위한 지원을 주요한 사업으로 설정할 필요가 있다. 지 방자치단체가 문화자원을 발굴 및 기획하고 운영할 수 있도록 지방자치단체 역량강화 보조사업예산을 지원하거나 중앙에서 전문가 풀을 제공하여 지방자치단체가 자문을 구 
할 수 있도록 하는 것이다.

그리고 문화도시 조성이 도시경영 측면에 매몰되지 않고 생활문화 서비스를 주요하게 고려될 수 있도록 생활권 포괄보조 프로그램을 연계하는 방안이 적절하다. 즉 단일 지방 자치단체에서 생활권 포괄보조 계획이 커뮤니티 단위로 정리되어 문화도시조성사업 계 획에 담기도록 하는 것이다. 현행 문화도시조성사업의 예비도시 단계를 생활권 단위 포 괄보조 프로그램으로 대체하거나 혹은 문화도시 심의에 생활권 단위 포괄보조 프로그램 활성화 지역에 가점을 부여하는 방안을 검토할 수 있다.

\section{3) 광역권 단위 포괄보조}

광역권 단위 포괄보조는 문화적 자원(역사전통, 예술, 문화산업, 사회문화 등), 생활환 경의 유사성 혹은 연결성이 높은 자치단체가 행정구역에 얽매이지 않고 광역권 계획 수 립에 대한 포괄보조를 의미한다. 즉 광역권 권역은 정형화된 행정체계가 아닌 문화적 특성을 반영한 분야, 그리고 연계협력이 용이한 지역을 통합한 개념이다. 대구 경북 통 합과 같은 시도통합 형태와 부울경메가시티와 같이 특정 분야에 대한 지방특별자치단체 유형이 새롭게 나타나고 있는 가운데, 이러한 지역체계에서 광범위한 문화서비스를 계획 할 수 있도록 포괄보조 프로그램을 설계하는 것이다.

광역권 단위 포괄보조는 '지역문화권역'을 중앙정부에서 설정하고 지방자치단체가 공 동계획 혹은 연계된 개별 실행계획을 수립되는 방식이다. 즉 중앙정부 차원에서 지역사 회의 재정여력, 인구, 문화기반시설, 문화제공 인력, 생활환경, 이동성 등을 종합하고 핵 심이슈에 따라 지역을 유형화한 지역문화권역화 작업이 선행되어야 한다. 


\section{제2절 중앙-지자체 간 협조체계 및 재정배분}

\section{1. 종합진단}

\section{가. 지자체의 자율성·책임성}

성과협약형 포괄보조 방식은 지방정부에 대해 사업계획과 집행의 재량을 확대하면서 결과지향적인 성과책임을 강화하는 재정혁신 효과를 기대할 수 있다. 국가 전체적인 관 점에서 공공서비스를 관리해야 하는 중앙정부의 국가적 목적과 지역맞춤형으로 국비 등 외부재원을 효율적으로 사용하여 지역문제를 해결하는 지방자치단체의 지방적 목적이 양립 가능해야 하는 것이다.

그동안 지방분권에서 자율성과 책임성을 강화하고 중앙정부와 지방자치단체 간 대등한 관계를 형성하고자 국고보조금 관계를 재편하는 노력이 이어져왔는데, 과거 경험들을 종 합할 때 정부 간 재정관계의 논의와 제도들은 중앙정부 관점에서 추진되었다. 보조금의 비용-효과성이나 문제해결 혁신 그리고 지역사회와 지방자치단체의 관점들은 제대로 고 려되지 못하였고, 중앙정부의 하향식 분권 추진과 지방자치단체의 소극적 적응 행태가 일 반적이었다. 지난 20여년 기간동안 분권을 위한 노력과 지방이양, 국고보조사업 방식의 개편 등이 진행되어는 왔으나, 개별국고보조 방식으로 회귀하는 경험을 거치면서 중앙정 부와 지방자치단체 간 신뢰기반은 보다 약화되었다. 그리고 포괄보조형 사업이 지방자치 단체 입장에서는 재원이 국가예산이기 때문에 지역사회와 주민의 통제로부터 상대적으로 자유롭기 때문에 잠재된 정보격차와 도덕적 해이에 따른 책임성 쟁점이 여전히 존재한다.

최근 시도되고 있는 지방자치단체 계획에 대한 포괄보조 방식의 사업들은 계획단계에서 상당히 체계적이고 구체적인 계획서가 요구되고, 사업의 종류, 예산의 용도 등에 전제조건 이 요구되고 있었다. 국가의 정책적 지향점과 목표를 지방자치단체와 공유하기 위한 조건 인데, 과도한 전제조건이 지방자치단체의 사업기획 및 집행 유연성을 제약하기도 한다. 


\section{나. 지자체의 기획역량}

성과협약형 포괄보조 사업의 핵심은 지방자치단체의 기획역량이다. 그리고 지방자치 단체의 보유 문화자원과 기획 역량은 지역사회 내 재정여력, 인구, 문화기반시설, 생활 환경 등 지역사회가 가지고 있는 핵심이슈에 따라 다르다. 그런데 현재 문화도시와 같은 문화분야의 포괄보조형 사업은 모든 지방자치단체에 동일한 조건의 공모방식으로 추진 되고 있다. 공모형 방식은 지역의 재량으로 선택하기 때문에 지역맞춤형 이점이 있는 반면, 지방자치단체들 간 국비유치를 위한 약탈적 경쟁 현상이 발생할 수 있다.

지방자치단체의 기초 역량에 격차가 있는 상황에서 성과협약형 포괄보조 방식을 강력 하게 적용하면, 지역의 발전격차는 보다 커지게 된다. 지역 간 차이가 상당할 경우, 포괄 보조에서 지역의 재량을 확대하는 공모방식은 지방정부의 사업역량에 따라 지역문화 양 극화 현상이 보다 악화될 위험이 있기 때문이다. 본 연구에서 진행한 지방자치단체 공무 원 설문조사 결과에서도, 포괄보조형 사업인 문화도시사업에 관련된 자치단체는 그렇지 않은 자치단체보다 지역사회 내 기획역량이 풍부하였다(기획역량 충분 의견: 예비도시 $50 \%$, 본도시 $38.9 \%$, 추진예정 34.7 , 관계없는 지방자치단체 $11.7 \%$ ).

사회 경제 활동이 집중되는 수도권 지방자치단체와 지역소멸 우려성이 높은 낙후지역 의 기획역량이 현저히 다르고, 특광역시와 같은 도시형 행정구역에 속해 있더라도 노령화, 슬럼화가 진행되고 있는 특성이 나타나고 있다. 동일한 계층의 모든 지방자치단체에 대해 표준적인 사업지침을 전달하는 현재의 정부간 재정관계가 현실적으로 계속 유효할 수 있는 지에 대한 구조적인 쟁점들이 발생하고 있다. 지역맞춤형 분권 접근이 필요하고, 포괄보조 프로그램에서도 지역특성별로 프로그램 운영 방식을 다양하게 설정할 필요가 있다.

지방의 자치분권에서 전제조건은 자치권, 관할구역, 주민 등 세 가지이다. 최근 한국 사회에서는 지방자치의 구성조건에서 변화가 상당하다. 정부간 수직체계가 중앙-지방간 수평체계의 자치거번넌스로 전환되고, 시도통합과 특례시 등의 지방행정구역 및 행정체 계 변화 요구도 상당하다. 서비스 사회로 전환과 주민들의 지리적 이동과 정주특성변화 에 따라 지역사회 주민구성의 이질성과 다양성이 지방정책에서 주요 변수가 된다. 수도 권 집중과 지역소멸 위험 지방자치단체의 대량 발생 가능성 역시 문화분권의 제도 설계 에서 유의해야할 구조적 변수들이다. 


\section{다. 성과정보 측정과 관리}

지역문화 활성화의 성과를 설정하는 것이 쉽지 않지만, 성과정보의 측정과 관리가 가 능한 전략적 성과관리체계를 정립해야 한다. 궁극적인 정책 목표가 명료해야하고, 포괄 보조 방식이 정책 목적 달성에 얼마나 기여하였는가를 측정하고 설명할 수 있어야 한다. 중앙부처와 지방자치단체가 지역문화사업의 성과를 바라보는 관점과 방향성의 일치, 포 괄보조형 재정사업이 완료된 이후 혹은 추진 과정에서 주목해야 하는 지역문화 정책의 실질적 혹은 결과지향적 목표 설정에 대한 것이다. 성과관리체계에서 핵심은 전략적인 성과관리 지표를 개발하고 정부간에 공유하는 것이다. 중앙정부의 중장기 지역문화 관련 계획과 함께 1 년단위 업무계획을 검토하여 지방자치단체의 문화정책과 연계하는 것이 중요하다.

현재로서는 국가 지역문화정책의 비전과 프로그램의 전체 목표 수준과 내용을 고려할 때, 총괄적인 성과지표와 목표의 연계성이 부족하다. 문화체육관광부 성과관리 시행계획 상 '지역문화 활성화' 의 성과지표 지역문화전문인력 양성사업 참여자 만족도(점), 생활문 화동호회 지원사업 참여 동호회수(개)와 문화체육관광부 업무계획 상에 박물관·도서관 등 문화기반시설 증가는 단순 산출 성격이다. 이는 주제어인 "균형", "문화향유", "기회 확대"의 상위 가치와 직접적인 연계성이 명확하지 않고 개별사업에 대한 산출지표 성격 의 한계가 있다. 지역규모별 문화향유 성과지표와 성과목표는 개별사업에 대한 단순산출 성격이다.

최근 1-2년 전부터 문화도시, 관광거점도시, 계획공모형 지역관광개발 등 포괄형, 상 향형 사업형태가 운영되고 있다. 이 사업들은 중앙정부가 사업유형 혹은 정책방향을 제 시하면 지방자치단체에서 수요에 맞는 계획을 세우고 이를 중앙정부가 승인한 경우에 다년간 포괄예산을 주는 방식이다. 현재까지는 성과계약 관점의 접근보다는 지방자치단 체의 계획에 대해 종합지원, 포괄 지원하는 보조금 통합 측면에서의 재정지원 의미를 두고 있는데, 포괄보조 사업이 분권적 가치를 담고 순기능을 발휘하기 위해서는 성과관 리 설계가 중요하다. 


\section{2. 도입방안}

\section{가. 중앙-지방자치단체 간 신뢰 기반 형성}

성과협약형 포괄보조 방식은 국고보조금 이용범위와 용도에 재량을 확대한 형태인 포 괄보조금에 대한 운용조건 중 하나로 반드시 계약 혹은 협약이 동반되어야 하는 것은 아니다. 다만 그동안의 포괄보조 방식의 사업의 추진 경험에서 비용효과성에 순기능이 작동되지 못한 원인을 중앙정부와 지방자치단체 상호간에 책임성과 신뢰관계 부족으로 판단되기 때문에 책임성과 신뢰관계 형성을 위해 협약 절차를 포함하는 것이다. 중앙정 부와 지방자치단체 간에 상호협의하고 성과를 구체적으로 명문화하는 과정을 통해 상호 권한과 역할, 이익, 책임 등을 분명히하고 협력사항을 사전에 구체화한다는 점에서 포괄 보조 방식의 순기능이 발휘될 수 있기 때문이다.

그런데 협약의 형태는 사업 예산 확정 단계에서부터 배분 원칙과 대상, 절차 등을 관 보에 게재하고 정해진 일정에 따라 지역의 상황을 지방정부에서 자체적으로 파악한 후 제출하는 상세계획 협의과정이 필수적이기 때문에 상호 신뢰관계가 선행되어야 한다. 현 실 제도에서 운영됐던 포괄보조프로그램의 다양한 사례와 특성들에 대해 상호 이해관계 를 우선 공유해야 한다. 특히 문화분권의 성과주의 혁신을 목적으로 포괄보조프로그램을 도입할 경우 중앙정부의 국고보조금 예산절감, 사업관리 감독 강화 등의 소극적인 목적 으로 포괄보조프로그램을 운영하는 것이 아니라는 점이 강조되어야 한다. 또한 정부간 성과협약형 포괄보조는 지역문화 진흥을 위한 사업 혹은 성과 자체에 핵심 목적이 설정 된다는 점을 명시적으로 규정해야 한다.

지방정부 혹은 사업의 집행현장에서 포괄보조에 대한 잘못된 인식이 형성되어 있으면 국고보조사업의 비효율을 창출하는 정보격차와 도덕적 해이의 비합리적인 재정행태가 발생한다. 따라서 중앙정부의 선한 의도가 실질적으로 선한 의도라는 점을 제도적으로 보장해야 한다. 제도 목적과 필요성에 대한 공유와 운영방식에 대해 중앙과 지방간 상호 신뢰가 우선 전제되어야 하는 것이다. 이와 관련하여 포괄보조프로그램을 도입할 때 사 업현장에서의 자발적 협력과 동의가 형성될 수 있도록, 제도시행 전 단계에서 지방정부 와 사전 협의와 정례적인 상호 협력체계의 구축·운영이 공식적으로 제도화되어야 한다. 


\section{나. 협약 대상 및 재원배분 방식}

1) 협약 대상 지방자치단체: 기초 vs 광역

성과협약형 포괄보조 방식은 성과책임을 전담하는 주체와 협약을 체결해야 한다. 이 는 사업의 성과책임을 보장하는 제도운영의 직접적인 관계 주체를 설정하는 것으로 중 앙과 지방간 사업파트너십에서 광역자치단체 혹은 기초자치단체의 관계를 설정하는 것 이다. 협약의 대상은 지역사회 내 문화적 수요를 관리하고 전략적으로 공급할 수 있는 단위의 지방자치단체가 적합하고, 중앙부처의 1 개 조직에서 관리하므로 협약대상 수가 과다하게 많으면 행정부담 문제가 발생한다.

지역문화사업의 재정적 혹은 시설적인 특성에 따라 광역자치단체와 기초자치단체간 기능분담이 형성돼 있다. 상당 수 국고보조사업들은 광역자치단체를 경유하여 기초자치 단체가 실질적으로 사업집행을 담당한다. 문화체육관광부 지역문화과 소관 사업인 문화 시설 건립, 문화서비스 제공, 문화도시 조성 등이 주민 생활권 내 이루어지는 사업으로 그간 광역자치단체에서 개별시설 혹은 프로그램 운영에 제한적인 역할을 하였다.

그런데 광역자치단체의 재정조정 능력이 자치단체의 특성에 따라 다른 점에 유의해야 한다. 특광역시의 경우는 시본청에서 직접 수행하는 사업들이 많고 자치구에 대한 재정 조정기능이 활성화되어 있다. 하지만 도와 시군간의 관계는 재정특성이 다르다. 도의 재 정이 전반적으로 취약하고 군의 면적이 넓기 때문에 도에 재정조정과 사업관리 권한을 부여하면 광역-기초간 재정갈등이 발생할 가능성이 높아진다. 또한 인구100만명이 넘 는 대도시(특례시)들은 중앙-도-특례시의 중층 관계 보다는 중앙-특례시의 단층 관계가 적합하다.

따라서 지역문화 성과협약형 포괄보조 프로그램에 대한 지방자치단체 협약 대상은 특 광역 시는 광역자치단체로 하고, 광역도는 기초자치단체인 군 단위로 설정하는 것이 적 절하다. 특광역시는 하위 자치단체인 자치구 단위를 연계하고 전략적으로 투자되어야 할 자치구를 결정하는 등의 조정기능을 강화하고 지역문화 성과협약형 포괄보조 프로그램 의 성과책임 주체가 되는 것이다. 그리고 광역도와 자치군은 중층관계가 아닌 자치군 독립적으로 성과책임 주체가 되어 사업의 기획 및 평가에 직접적인 주체가 되는 것이다. 여기서 협약대상은 자체 모니터링 기능과 평가능력을 갖추어야 한다. 


\section{2) 재원배분 방식}

지역사회 역량과 자원은 지방자치단체별로 현저하게 다르다. 주로 광역도의 관할구역 에 해당되는 지역은 재정자립도가 낮고 지방자치단체 총지출 대비 문화예술 예산 편성 비중이 낮지만 지역에 인구 백만명 당 문화시설이 많다. 재정여건이 양호하지 않은 지역 에서 인구대비 문화시설 개수가 많으면, 시설건립 이후 운영 및 활성화에 대한 투자 부 족으로 지역격차가 악화될 수 있다. 이러한 상황에서 사회 경제 활동이 집중되는 수도권 지방자치단체와 지역소멸 우려성이 높은 낙후지역의 지방자치단체에 대한 문화분권과 포괄보조제도가 동일한 형태로 적용되는 것은 적절하지 않다.

〈표 5-4〉 지자체별 재정자립도, 문화예술예산, 문화기반시설 수

(단위: 백만원, 개, \%)

\begin{tabular}{|c|c|c|c|c|c|c|}
\hline \multirow{2}{*}{ 지 역 } & \multicolumn{2}{|c|}{ 재정자립도 } & \multicolumn{2}{|c|}{ 지자체 문화예술 부문 예산 } & \multicolumn{2}{|c|}{ 백만명당 문화시설 수 } \\
\hline & 지수 & 순위 & 예산비중 & 순위 & 개수 & 순위 \\
\hline 서울특별시 & 75.6 & 1 & 1.39 & 12 & 42.14 & 12 \\
\hline 부산광역시 & 46.1 & 6 & 1.94 & 4 & 36.32 & 17 \\
\hline 대구광역시 & 44.6 & 7 & 1.76 & 7 & 36.50 & 16 \\
\hline 인천광역시 & 50.3 & 4 & 1.44 & 11 & 38.89 & 15 \\
\hline 광주광역시 & 40.8 & 8 & 2.84 & 1 & 49.43 & 10 \\
\hline 대전광역시 & 39.9 & 9 & 1.86 & 5 & 42.04 & 13 \\
\hline 울산광역시 & 49.6 & 5 & 2.24 & 2 & 40.07 & 14 \\
\hline 세종특별자치시 & 58.8 & 2 & 2.18 & 3 & 64.60 & 9 \\
\hline 경기도 & 57.3 & 3 & 1.68 & 10 & 42.83 & 11 \\
\hline 강원도 & 24.5 & 15 & 1.73 & 9 & 150.50 & 2 \\
\hline 충청북도 & 28.3 & 13 & 1.30 & 14 & 85.00 & 5 \\
\hline 충청남도 & 32.3 & 12 & 1.29 & 15 & 82.87 & 6 \\
\hline 전라북도 & 23.1 & 16 & 1.80 & 6 & 95.66 & 4 \\
\hline 전라남도 & 22.2 & 17 & 1.15 & 16 & 118.80 & 3 \\
\hline 경상북도 & 24.9 & 14 & 1.35 & 13 & 79.15 & 7 \\
\hline 경상남도 & 33.5 & 10 & 1.08 & 17 & 65.72 & 8 \\
\hline 제주특별자치도 & 32.7 & 11 & 1.76 & 8 & 205.67 & 1 \\
\hline 평 균 & 43.6 & - & 1.55 & - & 58.19 & - \\
\hline
\end{tabular}

주: 재정자립도, 지자체 문화예술부문 예산은 2021년, 시설 수는 2020년말 기준

자료: 문화체육관광부(2021), 2020 전국문화기반시설총람

지방재정통합공개시스템(재정365) 
모든 지역을 동일한 기준으로 계획을 평가하게 되면 사업 역량에 따른 지역격차는 심 화된다. 따라서 지역특성별 관리방식을 차등화하고 보조율, 총액할당규모 설정, 선정기 준 강화 혹은 완화와 같은 지역 맞춤형 포괄보조 프로그램을 설계할 필요가 있다.

\section{다. 포괄보조형 사업에 대한 성과관리 체계화}

\section{1) 과정관리와 성과관리의 구분}

포괄보조형 사업에 대한 분석은 과정관리(Process Control)와 성과관리에(Result Based Management) 대한 구분된 접근이 필요하다. 포괄보조형 사업은 중앙정부가 사 업영역을 정의하고 지방자치단체에서 사업내용과 방식을 설계하는데, 이러한 방식은 지 방자치단체의 사업설계 재량권을 보다 많이 부여하고 행정절차가 간소하다는 특징을 가 진다. 그런데 현재 문화도시와 같은 포괄보조형 사업은 성과관리 방안이 체계화 되는 과정을 거치고 있는 상태로, 사업계획 단계와 과정관리에 많은 과다한 행정력이 요구되 고 있다. 개별보조사업에서 경험하지 않은 수요분석, 지역진단, 계획수립, 의견수렴 등의 업무와 이 모든 것을 문서화하여 중앙정부와 협의하는 절차, 진행경과에 대한 결과보고 서 작성과 실적평가 등이다. 지방자치단체 사업운영 자율성에 부여에 따르는 책임 강화 측면에서 사업과정에 대한 점검과 모니터링을 중요한 미션으로 인식하고 대응하는 것은 분명 필요하지만, 과정관리와 성과관리에 구분이 모호하게 진행되고 있다. 실적에 대한 점검과 모니터링, 컨설팅은 정책수행 과정에서 발생한 문제점, 장애요인, 개선점을 도출 하기 위한 과정관리에 목적을 두어야 한다. 그런데 현재의 방식은 1 년 경과 시점에서 우수 혹은 미흡의 성과를 다루는 성과평가 형식의 성과관리가 이루어지고 있다. 성과관 리가 체계화되지 못한 문제를 과정관리를 강화하는 방식으로 전개되고 있는 것이다. 이 것은 애초에 의도했던 지방자치단체, 기관의 자율성, 재량권을 약화시키고 사업운영 과 정 및 성과에 대한 이중적 책임이 강화되고 업무 부담이 가중되는 결과를 가져온다. 특 히나 문화사업은 가치지향적이기 때문에 단기적 성과와 효율성 중심의 관리방식은 부적 합하고, 1 년 경과시점의 결과를 성과 자체로 판단할 수도 없다.

따라서 과정관리와 성과관리는 관리목적과 방법이 구분되어 진행되어야 하고 균형을 이루어야 한다. 과정관리가 성과평가적 방식으로 이루어지거나 과정에 대한 지침과 조건 이 과도하게 부여되면 개별 국고보조와 크게 다르지 못하여 지방자치단체의 자율성은 
저해되고 행정력 부담만 가중된다. 과정관리는 매년 실적을 정리하면서 수행과정의 장애 요인과 개선점을 도출할 수 있는 컨설팅 중심으로 진행하고, 3 년 혹은 5년 경과 시점에 연간 실적점검 결과를 참고하고 성과목표 달성도를 종합하여 성과평가가 진행되어야 한 다. 성과평가는 대표지표 2 3개가 적당하고 결과 중심의 평가가 되어야 한다. 과정관리 결과는 지방자치단체 내 공유하는데 집중하고, 성과평가 결과는 대외적으로 시례를 확산 하고 지방자치단체 및 담당자에 대한 상으로 환류되어야 할 것이다. 성과지표와 평가결 과의 공개는 지역사회의 참여와 비판을 강화하는데 중요한 방법이다.

\section{2) 지자체 내 평가기능 강화}

중앙정부의 세부 사업지침을 완화하면서 지방자치단체의 사업재량을 확대하여 지방 자치단체 중심의 사업운영이 활성화될 수 있도록, 지방자치단체 내 평가기능을 강화할 필요가 있다. 1 개의 중앙부처가 수 많은 지방자치단체와 성과를 협약하고, 수행 사업의 정보를 정확하게 수집하고 엄밀하게 점검하는 것은 불가능하다. 따라서 성과협약형 포괄 보조 방식의 효과적인 운영을 위해서는 지방자치단체 내에서 지역 실정에 맞게 사업수 행을 점검하고 모니터링하는 평가기능 강화가 중요하다. 이것이 지방자치단체의 사업운 영 재량과 목표달성 관리 차원에서도 효과적이다.

이를 위해 광역단위의 성과지표를 개발하고 평가체계를 구축하는 시례는 지속적으로 늘어나야 하고, 이를 활용하여 정기적으로 평가하고 문제점, 장애요인, 개선방안을 도출 하여야 한다. 중앙정부는 성과협약형 포괄보조와 관련된 인식제고 교육과 성과관리 교 육, 컨설팅을 제공해야한다. 지방자치단체가 관심을 가질 수 있는 문화지표는 중앙정부 주관으로 이미 측정 및 활용되고 있는 경우가 많기 때문에, 성과지표에 대한 자문과 컨 설팅에 중앙정부 차원의 지원이 중요하다.

\section{3) 실질적 인센티브 방안}

재원에 따른 책임성을 담보할 수 있게 성과평가는 반드시 이루어져야 하고, 성과에 따른 재원배분에 인센티브와 패널티가 부여되어야 한다. 문화도시 사업은 지난해 1 년 수행기간에 따른 성과평가를 진행하였고 결과를 순위로 정리하여 지방자치단체 간 공유 하였고, 우수한 결과로 판단되는 지방자치단체는 사업비 인센티브를 주었다. 이러한 방 
식은 지방자치단체의 사업운영을 목표지향적으로 이끌기 보다, 지방자치단체에 순위를 매김으로서 지방자치단체 간 견제를 강화하게 되었다. 그리고 인센티브로 제공한 사업비 는 소액이면서 지방비 매칭을 조건으로 하다보니 지방자치단체 의회에 사업계획을 수정 하는 등의 절차가 추가되면서 사업의 확대보다 행정비용이 더 소요되었다.

따라서 지방자치단체의 성과를 유도하는 실질적 인센티브 방안을 마련할 필요가 있 다. 매칭이 필요없는 특별사업비를 지급하거나 포상금을 지급하는 등 재정적 인센티브를 부여할 때 지방자치단체의 실질적 혜택을 제공할 필요가 있다. 또한 성과평가는 3년, 5 년 단위의 일정기간에 대한 사업수행 결과와 목표달성 성취수준이 나타나기 때문에, 추 가사업비 보다 강력한 유인책이 되는 재협약 우선권, 총액예산의 $1 \sim 5 \%$ 포상금 등도 검 토할 수 있다. 또한 성과협약형 포괄보조 방식은 지방자치단체 뿐만아니라 전담조직, 전 문가 등 다양한 관계자의 적극적인 참여가 필수적이므로, 성과달성에 기여한 실질적 주 체에게 성과보너스, 포상 등의 인센티브를 마련하는 것도 고려할 수 있다. 



\section{참고문헌}

- 김우림(2021), 사회복지 분야 지방자치단체 국고보조사업 분석, 국회예산정책처.

- 농촌축산식품부(2021), 2021년 농촌협약 추진계획.

- 문화체육관광부(2021), 2020 전국문화기반시설총람.

- (2021), 2021 문화도시 추진 가이드라인.

- _ (2021), 2021년도 성과계획서.

- _ (2021), 2021년도 업무계획.

• _ (2021), 2021년 성과관리 시행계획.

- 는 (2020), 균특회계 포괄보조사업 가이드라인.

- 박병희·이재원·이종하(2020), 국고보조사업 분류체계 개편에 관한 연구, 한국지방재 정공제회.

- 보건복지부(2021) 2021 가사·간병 방문 지원사업 안내.

- (2021) 2021 산모·신생아 건강관리 지원사업 안내.

- _ (2021) 2021년도 지역사회서비스 투자사업 안내.

- (2021), 2021년도 지역자율형사회서비스투자사업 시도평가 추진계획

- _ (2014), 지역자율형사회서비스 투자사업 안내.

- 새문화정책준비단(2018), 문화비전 2030: 사람이 있는 문화.

- 이재원(2016), 국고보조사업 운영의 효율성 제고를 위한 정책과제, 한국지방세연구원.

- _ (2016), 국고보조금제도 개선을 위한 정책의제, 한국지방재정학회 세미나자료 집, 33-53.

- _ _ (2009), 포괄보조 방식을 통한 분권 지향적 국고보조금 운용 과제: 분권교부세, 균 특회계, 그리고 지역사회서비스투자사업을 중심으로, 한국지방재정논집, 14(1), 57-89.

- 이재원·김은정·김윤수(2007),사회복지분야 재정분담 적정화를 위한 국고보조금제도 개편방향, 한국지방재정학회.

- 정보람(2020), 지방분권에 따른 문화재정 현황과 정부간 역할분담 방안, 한국문화관광 연구원. 
- 행정안전부(2021), 2021년 지방자치단체 통합재정개요.

- 한국지방세연구원(2018), 국고보조금 기준보조율체계 개편방안 연구, 대통령소속자치 분권위원회.

- Jaroscak(2021), Support Local Development and Infrastructure Projects Through the Community Development Block Grant (CDBG) Program, 2021 Policy Brief

- Jaroscak, Joseph V., Lawhorn, Julie M., Dilger, Robert Jay(2020), "Block Grants: Perspectives and Controversies", Congressional Research Service (2020), CRS Report, updated February 21, 2020.

- Joseph V. Jaroscak (2021), Community Development Block Grants: Funding and Allocation Processes, Congressional Research Service, CRS Report, March 24, 2021.

- Keith Wiley (2014) The Role of the CDBG Program in Rural America, Housing Policy Debate, 24:1, 238-257.

- Lamia, T. L., Lowry, G. F., McLees, A. W., Frazier, C. M., \& Young, A. C. (2021). Improving Outcome Accountability of Block Grants: Lessons Learned From the Preventive Health and Health Services Block Grant Evaluation. American Journal of Evaluation, 42(2), 185-200.

- OECD(2010), Regional Development Policies in OECD Countries, OECD, Paris.

- _ (2007), OECD Territorial Reviews: Luxembourg, OECD, Paris.

- United States Government Accountability Office(2019), DISASTER RECOVERY: Better Monitoring of Block Grant Funds Is Needed.

- United States Government Accountability Office (2014), GRANT PROGRAM CONSOLIDATIONS: Lessons Learned and Implications for Congressional Oversight.

- Youm, J. and Terman, J. (2020), Dynamic Collaboration: The Effects of External Rules and Collaboration Scope on Interlocal Collaboration. Rev. Policy Res., 37: 823-841. 


\section{〈웹사이트〉}

- 열린재정(재정정보공개시스템) https://www.openfiscaldata.go.kr

- 이나라도움 https://www.gosims.go.kr

- 지역문화진흥원 홈페이지 http://www.rcda.or.kr

- 지방재정통합공개시스템. http://lofin.mois.go.kr

- 행정안전부 주민등록 인구통계 https://jumin.mois.go.kr 



\section{ABSTRACT}

\section{A Study on the Implementation Method of Performance Agreement-Type Block Grant System of Local Culture}

Boram Jeong

This study proposes a financial management system to improve the limitations of the top-down fund allocation system planned by the central government and enforced by the local authorities. Simultaneously, a transition to a function-sharing system is proposed, in which the local authority and the central government cooperate in local cultural policy planning. In particular, the "performance agreement-type block grant system" was reviewed with the intention of strengthening performance management in the block grant system of government subsidies.

From the decentralization perspective, local cultural promotion should, in principle, be at the initiative of the local authority that can understand local conditions in real time, and mobilize firsthand the available local resources more efficiently. However, as the central government's subsidy disbursement system has taken hold, local authorities tend to resort to sole delivery or execution of the central government's plan and focus on competing to attract subsidized projects to secure funding to supplement their financial shortfalls rather than resolving local issues. The Ministry of Culture, Sports and Tourism has the fourth-largest government budget disbursed to local governments, with the highest number of small projects (based on individual project information) among all ministries, the majority of which are wasted, largely due to the rigid administrative structure. Ministries with high budget ratios allocated to local government find themselves 
highly dependent on the central government for their funds and thus actively look for ways for local governments to be more financially accountable. The welfare and agriculture sectors, which are as heavily subsidized by the government as the cultural sector, are reforming the financial relationship between the central government and local governments through block grant pacts and close cooperation with local authorities in budget planning.

This study examined the necessity of implementing local culture performance agreement-type block grants; analyzed the previous block grant-type projects of the Ministry of Agriculture, Food and Rural Affairs, Ministry of Health and Welfare, and Ministry of Culture, Sports and Tourism; and reviewed the basis of block-granting local culture projects through surveys of local government employees. Through a comprehensive analysis of previous studies, the possibility of block-granting local cultural projects was assessed, and ways to implement local culture performance agreement-type block grants and future assignments were subsequently proposed. For the performance agreement-type block grant to work smoothly, the governance, collaboration system, financial allocation relationship, and the like must be put in place first for projects tied to blocks to run efficiently.

Research results show that to implement the block grant method for local culture performance agreements, first, a redesign of the nation's local cultural policies, objectives, and task areas is necessary, such that the local cultural services, infrastructure, and human resources are supported in an integrated fashion. Second, it is necessary for the design to distinguish the programs for small village-level units that bestow autonomous policy decision-making power to local authorities from programs for strategically focused investment intended for wider administrative units.

Third, for the local authority units that are subject to the agreement, it is appropriate to set special metropolitan areas (SMAs) as metropolitan councils and wider provinces as basic local authorities (county-level). This is because many projects in SMAs are directly carried out by the city hall, and SMAs can adjust their own financial resources at the district level, while provinces in general are financially vulnerable, in part because of the distance between counties within 
provinces. Fourth, it is necessary to develop a resource allocation method that is custom-tailored for each region, which must be designed in consideration of financial conditions, cultural resource level, population makeup, living environment, and mobility. In the future, policy tasks such as categorization of local cultural regions, operation of pilot projects, and systematization of performance management for comprehensive subsidy projects by the Ministry of Culture, Sports and Tourism should be pursued.

\section{Keywords}

Block Grant, Performance Agreement, Local Culture 

지역문화 성과협약형 포괄보조 방식 도입방안 연구

\section{부록}

설문지 



\section{【부록1】지방자치단체 공무원 설문지}

\section{'문화분야 포괄보조형 사업[문화도시 등]' 에 대한 설문조사}

안녕하십니까?

문화체육관광부 산하 정책연구기관인 한국문화관광연구원에서는

「지역문화 성과협약형 포괄보조방식 도입방안 연구」의 일환으로

'문화분야 포괄보조형 사업(문화도시 등) 운영'에 관한 공무원 설문조사를 실시하 고 있습니다.

문화도시조성사업 추진 예정이거나 이미 추진하고 있는 지방자치단체 관련 부서 공 무원분들의 의견을 수렴하고자 하며, 해당 사업 담당경험이나

관심이 있으신 모든 공무원분들의 응답을 기다립니다.

본 설문조사 내용은 무기명으로 통계 처리되어 참여자의 신상정보는 일체 공개되지 않으며, 정책자료 목적 외에는 어떠한 목적으로도 사용되지 않고 통계법 33조에 의하여 비밀이 보장됩니다. 설문문항은 18 개이며 약 5 10분이 소요 됩니다. 바쁘신 중에도 본 설문조사에 참여해 주셔서 감사드립니다.

\section{1년 7월}

한국문화관광연구원 문화정책연구실

■ 연구기관: 한국문화관광연구원

■ 연구책임: 정보람 부연구위원(brj@kcti.re.kr)

■ 제 출 처: 글로벌리서치 박경하 대리(khpark@globalri.co.kr)

■설문참여 방법: (1) 이메일 제출, (2) $\mathrm{QR}$ 코드를 이용한 온라인 참여 중 택 1

(1) 설문지 이메일 회신: khpark@globalri.co.kr (글로벌리서치 박경하 대리)

(2) QR코드를 이용하여 온라인 응답: 스마트폰 카메라 앱에서 QR코드 스캔 - 모바일 설문조사 연결

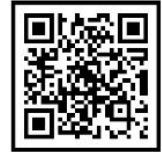

포괄보조사업이란?

포괄보조금은 특정 서비스 또는 계층에 대해 설계된 사업에 재정이 지원되는 개별보조금과 달리 넓게 정의된 기능별 목적에 따라 지원되는 재정지원 형태임

- 국고보조금은 재량권을 기준으로 개별보조금(Categorical grant)과 포괄보조금(Block grant)으로 구분

- 포괄보조는 실용적인 용어로 정책의 조건과 형태에 따라 다양한 용어로 사용되고 설계될 수 있으며, 문화분야에서는 '문화도시조성사업'과 같이 지역의 특성과 상황에 맞춰 계획을 수립하고, 중앙정부는 포괄적인 예산을 지원하는 방식이 해당됨 
기본 정보

\begin{tabular}{|c|c|c|c|c|c|c|}
\hline 소속지자체 & \multicolumn{3}{|c|}{ 시도) ( } & 시군구) ( & & \\
\hline 문화도시 여부 & \multicolumn{6}{|c|}{ (1) 예비사업 진행 (2) 본도시 지정 (3) 예비사업 등 추진 예정 (4) 해당사항 없음 } \\
\hline 성별 & (1) 남 (2) 여 & 직급 & (1) 4文 & |상 (2) 5급 (3) 6급 (2 & 급 & 급 (6) 9 급 \\
\hline \multirow{2}{*}{ 나이 } & \multirow{2}{*}{ 만 ___ 세 } & \multirow{2}{*}{$\begin{array}{l}\text { 근무 } \\
\text { 연수 }\end{array}$} & 1 & 공무원 근속년수 : & 년 & 개월 \\
\hline & & & 2 & 현재업무 근무년수: & 년 & 개월 \\
\hline
\end{tabular}

口 본 조사는 통계적 목적 이외에 다른 용도로 사용되지 않습니다

문화도시조성사업의 사업기획 및 정책과정에 대한 질문입니다

귀하의 의사를 가장 잘 나타내는 항목 1 개에 $\checkmark$ 표시를 해주십시오

\section{[사업기획]}

Q1. 문화도시조성사업추진을 결정·실행하는데 가장 영향력있는 주체는 어디입니까?

(1) 지자체장 의지에 따라 결정·추진

(3) 지자체 부서(과, 팀 등) 관심으로 결정.추진

(5) 기타:
(2) 지역 내 조직/단체 주도에 따라 결정·추진

(4) 전문가, 주민 등 의견을 반영하여 결정·추진

Q2. 지역 내 문화사업 관련 조직 및 인력의 기획역량은 어느 정도라고 생각하십니까?

(1)

매우 부족함
(2)

부족함
(3)

보통
(4)

충분함
매우 충분함

Q3. 문화도시조성사업을 추진하는데 지역주민의 참여와 의사결정 영향력은 어느 정 도라고 생각하십니까?

(1)

매우 부족함
(2)

부족함
(3)

보통
(4)

충분함
(5)

매우 충분함

Q4. 문화도시조성사업을 수행하기 위한 조직구성 및 대응체계는 어떠합니까?
(1) 민간 사업전담조직을 구성하여 총괄 운영
(2) 지자체 행정부서와 민간전담조직이 공동 대응
(3) 전문가 컨설팅을 참고하여 지자체 행정부서 대응
(4) 기타: 


\section{[사업집행]}

Q5. (문화도시 '예바사업 진행' 또는'본도시 자정'으로 문화도시 예산이 확정된 자자체만 응답) 문화도시조성사업의 재원교부 절차 및 불용액(예산이월) 관리 방식은 적절하다 고 생각하십니까?
(1)
보통

Q6. (문화도시 '예바사업 진행' 또는 '본도시 지정'으로 문화도시 예산이 확정된 지자체만 응답) 문화도시조성사업 집행과정에서 중앙정부의 관리 감독(보고 지휘 등)은 적절하 다고 생각하십니까?
(1)
(2)
(3)
(4)
보통
적절함
매우 적절함

전혀 적절하지 않음 적절하지 않음

Q7. (문화도시 '예바사업 진행' 또는'본도시 지정'으로 문화도시 예산이 확정된 지자체만 응답) 문화도시조성사업에 대한 보조금 지불정산, 사업보고 등 행정 및 재정관리가 효 율적이라고 생각하십니까?

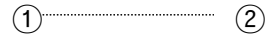

매우 비효율적임
(2)

비효율적임

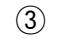

보통
(4)

효율적임

\section{(5)}

매우 효율적임

$\mathrm{Q} 7-1$. (위의 $\mathrm{Q} 7$ 에서 (1) 매우 비효율적임 또는 (2) 비효율적임 응답자만) 문화도시사업의 행정 및 재정관리에 대해 '비효율적이다'라고 생각하시는 이 유를 적어주십시오.

Q7-2. (위의 Q7에서 (4) 효율적임 또는 (3) 매우 효율적임 응답자만) 문화도시사업의 행정 및 재정관리에 대해 '효율적이다'라고 생각하시 는 이유를 적어주십시오. 
[사업평가 및 성과관리]

Q8. 문화도시조성사업으로 변화된 방향성은 어떠하다고 생각하십니까? 각 방향성에 대해 감소/약화 또는 확대/강화 중 1 개씩 표시해주십시오.

\begin{tabular}{|c|c|c|}
\hline 구분 & 감소/약화 & 확대/강화 \\
\hline 8-1 사업계획 및 추진 재량 & & \\
\hline 8-2 지자체 예산편성 및 집행 탄력성 & & \\
8-3 지자체 수요가 반영된 사업 추진 & & \\
8-4 유사. 중복성 사업의 통합, 재정효율화 & & \\
8-5 전문가 및 주민의 참여기회 확대 & & \\
\hline
\end{tabular}

Q9. 문화도시조성사업에 대한 성과책임 귀속 주체는 어디라고 생각하십니까? 상대적으로 중요하다고 생각하는 수준에 $\checkmark$ 표시를 해주십시오

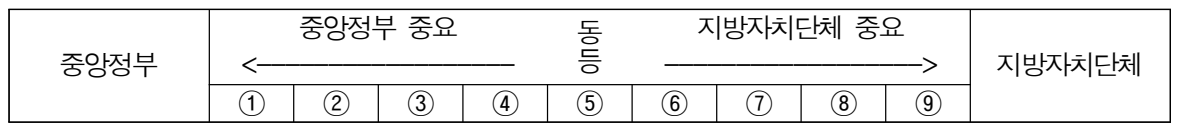

Q10. (문화도시 '예바사업 진행' 또는'본도시 지정'으로 문화도시 예산이 확정된 자자체만 응답) 문화도시조성사업에 대한 중앙정부의 성과평가제도는 적절하다고 생각하십니까?
(1)
(2)
(3)
(4)
보통
적절함
매우 적절함

전혀 적절하지 않음 적절하지 않음

Q10-1. (위의 $\mathrm{Q} 10$ 에서 (1) 전혀 적절하지 않음 또는 (2) 적절하지 않음 응답자만) 문화도시사업의 중앙정부 성과평가제도에 대해 '적절하지 않다'라고 생각하 시는 이유를 적어주십시오.

Q10-2. (위의 Q10에서 (4) 적절함 또는 (5) 매우 적절함 응답자만) 문화도시사업의 중앙정부 성과평가제도에 대해 '적절하다'라고 생각하시는 이유를 적어주십시오. 
문화도시조성사업 관련 중앙정부와 지방자치단체 간 관계에 대한 질문입니다

귀하의 의사를 가장 잘 나타내는 항목 1 개에 $\checkmark$ 표시를 해주십시오

[사업재량 및 재정분권]

Q11. 문화도시조성사업에 대한 중앙정부의 계획이 귀하의 지자체 정책(계획)과 어느 정도 일치하다고 생각하십니까?

$\begin{array}{lllll}\text { (1) } & \text { (2) } & \text { (3) } & \text { (4) } & \text { (5) }\end{array}$

전혀 일치하지 않음 일치하지 않음 보통 일치함 매우 일치함

Q12. 문화도시조성사업을 위해 지자체에서 마련한(혹은 마련 예정인) 계획이 지역수요 와 일치하다고 생각하십니까?

(1) (2)

전혀 일치하지 않음 일치하지 않음

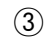

보통
일치함
매우 일치함

Q13. 귀하의 지자체 문화정책은 어느 분야에 가장 집중되어 있습니까?
(1) 전통/향토문화 지원
(2) 지역문화관련 활동인력 양성 및 배치
(3) 지역문화서비스(생활문화, 동호회 등) 지원
(4) 예술인 창작지원 및 복지
(5) 문화시설 개보수
(6) 벤처기업 및 창업지원
(7) 기타:

Q14. 지역기반 문화정책 가운데 지자체 차원에서 계획 및 관리해야 한다고 생각하는 분야는 무엇입니까? 해당되는 항목 모두 $\checkmark$ 표시 해주십시오.
(1) 전통/향토문화 지원
(2) 지역문화관련 활동인력 양성 및 배치
(3) 지역문화서비스(생활문화, 동호회 등) 지원
(4) 예술인 창작지원 및 복지
(5) 문화시설 개보수
(6) 벤처기업 및 창업지원
(6) 기타:

Q14-1. Q14에서 응답하신 분야들을 지자체 차원에서 계획 및 관리해야 한다고 생각하시는 이유는 무엇입니까? 


\section{[성과협약형 포괄보조에 대한 인식]}

\section{Q15. 지역문화사업의 연계·통합 추진을 위해 가장 중요한 요소는 무엇이라고 생각하십니까?}
(1) 지자체의 종합적인 문화사업 계획 수립
(2) 지자체(장)의 사업 효율화 방침(연계·통합)
(3) 지역 내 문화사업 수행 조직의 전문성
(4) 담당 공무원의 역량
(5) 기타:

Q16. 문화도시와 같은 포괄보조형 사업에서 지방자치단체의 가장 큰 어려움은 무엇이라고 생각하십니까?
(1) 제도 및 사업지침에 대한 이해 부족
(2) 재원조달 문제(상위/하위 지자체 협력 부족)
(3) 사업 수행주체 부재 혹은 수행 전문성 부족
(4) 전제조건 및 예산용도 제약 등 제한적 재량
(5) 성과지표 발굴 및 설정 어려움
(6) 기타:

Q17. 문화도시와 같은 포괄보조형 사업은 지자체 사업추진의 자율성, 창의성, 유연성 확 보에 어느정도 기여할 것으로 예상하십니까?

$\begin{array}{cccc}\text { (1) } & \text { (2) } & \text { (3) } & \text { (4) } \\ \text { 전혀 기여하지 않음 기여하지 않음 } & \text { 보통 } & \text { 기여함 } & \text { 매우 기여함 }\end{array}$

Q18. 기타 '문화도시와 같은 포괄보조형 사업 운영에서 정책과정, 중앙정부와 지방자치단체 간 관계와 관련된 의견이 있으시면 자유롭게 적어주세요

- 끝까지 설문에 응답해주셔서 감사합니다.

본 조사는 통계적 목적 이외에 다른 용도로 사용되지 않습니다. 
집필내역

연구책임

정보람 한국문화관광연구원 부연구위원: 제1장, 제2장, 제3장, 제4장, 제5장, 연구총괄

공동연구

이재원 부경대학교 행정학과 교수: 제2장1절 일부, 제4장1절 일부, 제5장 일부

연구 자문

박세경 한국보건사회연구원 선임연구위원

김재중 아츠피엠 대표

지역문화 성과협약형 포괄보조 방식 도입방안 연구

발행인 김대관

발 행 처 한국문화관광연구원

서울시 강서구 금낭화로 154

전화 02-2669-9800 팩스 02-2669-9880

http://www.kcti.re.kr

인 쇄일 2021년 10월 15일

발 행 일 2021년 10월 15일

인 쇄 인 (사)한국장애인이워크협회 일자리사업장

I S B N 978-89-6035-875-193300

DOI https://doi.org/10.16937/kcti.rep.2021.e13

이 연구보고서를 인용하실 때는 다음과 같은 사항을 기재해 주십시오.

정보람(2021), 지역문화 성과협약형 포괄보조 방식 도입방안 연구, 한국문화관광연구원 


\section{OPEN}

한국문화관광연구원

서울특별시 강서구 금낭화로 154

전화 02-2669-9800

팩스 02-2669-9880

www.kcti.re.kr 